\title{
A sors kritikájáról
}

\section{Vizsgálódások Walter Benjamin sorsfogalma mentén}

\author{
Lengyel Zoltán
}

Témavezető: Fried István

\author{
SZTE-BTK \\ Irodalomtudományi Doktori Iskola \\ Összehasonlító Irodalomtudomány Program
}




\title{
Tartalom
}

\author{
Prológus 2
}

ELSŐ RÉSZ (Sorstalanság) 10

I. Jog/erőszak 11

II. Ananké 47

III. Elpisz/Logosz 80

Epilógus/átmenet 112

MÁSODIK RÉSZ (Antichris + ) 124

IV.Gewalt/Gewalt. Erőszak/erő/hatalom. Mitikus/allegorikus természet $\mathbf{1 2 5}$

V. A bünbeeső természet $\mathbf{1 4 5}$

Epilógus. „Eredendő bün/szabadság”. Søren Kierkegaard szorongásértelmezésének adalékai Walter Benjamin sors- és nyelvfogalmához 164

Felhasznált irodalom $\mathbf{1 8 3}$ 
„[...] Én egy mindenestül idézetellenes ember vagyok, ellentétben vele. Az idézgetés az idegeimre megy. De be vagyunk zárva egy folyvást mindent idézgető világba, egy folyamatos idézgetésbe, amely $a$ világ, doktor. És mit tart egy olyan mondatról, mint ez: 'A véletlen azonban, s nem Isten, mint a tömeg hiszi, feltételezendő.' Ilyen mondatokkal operál a fiam. Minden cselekedet büntetendő cselekedet, és ezért olyan könnyủ minden cselekedetböl rögtön büntetendő cselekedetet csinálni. Emiatt lehet bárki ellen jogos halálos ítéleteket kimondani és végrehajtani. Az állam ezt a tényt ismerte fel. Erre alapul az állam. [...]"

A herceg, Megzavarodás, Thomas Bernhard

\section{Prológus}

A sors kritikájának feladatát úgy írhatnánk körül, hogy be kell mutatni a sors viszonyát a bünhöz és a szabadsághoz. Mind a bünhöz, mind a szabadsághoz az érzéki-természeti szférán keresztül igyekszik kapcsolódni a sors. Ez azt jelenti, hogy a sorsnak és a sorsszerü összefüggésnek minden esetben érzékelhető jelre, illetve érzékelhető jelek szimbolikus komplexumára van szüksége ahhoz, hogy alakot öltsön. Egy zárt, konfigurált világra. Másrészt azt is jelenti, hogy az érzékelhető-természeti szféra bármely jelensége a sors jelévé válhat, valamint ezen túl azt is, hogy, persze csak ha visszatekintve, utólagosan nézzük a dolgot, mintha nekik is szükségük volna a sorsra, hogy jelentésük és még inkább jelentőségük természetfelettivé növekedjen. A sors rendje az önmagán mitikus módon túlnőtt, természet- és emberfelettinek mutatkozó természet.

A sorsszerü rendek, valamint az ezen rendek fenntartásában érdekelt modern intézmények (hatalmi ágak) nem puszta átmenetet, hanem hasadást vagy hanyatlást képeznek ezekben a bünhöz és szabadsághoz való kapcsolódásokban. A sors igézetében funkcionáló hatalmi- 
mitikus orientációjú modern intézmények és társadalmi gyakorlatok (kiemelten az igazságszolgáltatás (jog), a tőle fokozatok révén elkülönülő büntetés-végrehajtás, valamint ezek nem-hivatalos kirajzásai) számára az jelenti az alapvető anomáliát, hogy - amint azt a jog kénytelen is érzékelni (ha nem is értelmezni) - sem a bünnek, sem a szabadságnak nem voltaképpeni szférája a természet. Szinte minden esetben ezzel az alapvető anomáliával függ össze az a gyakran megfigyelhető jelenség, ahogyan egy törvényi szabályozás végrehajtása során a jogalkotó deklarált céljától eltérő, nem egyszer azzal egyenesen ellentétes folyamat jön létre. Másik oldalról nézve az érzéki-természeti élet, és ezen belül az ember érzéki-természeti élete is, közvetve érzékeli és kifejezheti természetesen a bün és a szabadság hatásait - ez támaszthatja a mitikus gondolkodás számára a megoldhatatlan (nyelvi-szellemi) nehézséget, amely szigorúan (tragikusan) elzárja előle a megértés útját, valamint ugyanez a közvetett hatás teremti meg a hisztérikus politikai gondolkodás számára a lehetőséget, hogy a megértés feladatát végképp feladva, azelől a felelőtlen tevés-vevés és fecsegés határtalanságába futamodva, a bün és szabadság fogalmait a maga céljára eltorzítsa, vagy a már készen kapott torzulásokat tudatosan-tudattalanul felhasználja. A sorsszerű rend (elsősorban az állam) fenntartásában érdekelt modern intézmények ezért a természeti-eredendő „bünt” a maga mitikus-esztétikai (az attikai tragédiában legmagasabb művészi megformálódását és felbomlását elérő) komplexitásából kénytelenek „kiszabadítani” a lehető legaprólékosabb osztályozással élő szankcionálás révén, míg a hiányzó ellenpólust (melynek a büntetőjogi reformkorszak utáni jogi terminológiában az eljárás során az „ártatlan” és az „ártatlanság vélelme” felel meg) a „,szabadság” emberi jogi fogalmával ragadják meg. Felfogásom szerint ez sem a bün, sem az ártatlanság, sem a szabadság filozófiailag érvényes és gyümölcsöző megközelítéseit nem érinti. A természetieredendő (mitikus) „,bűn” a jog hatókörében szankcionálandó büntetté, és nem szigorúan erkölcsi értelemben vett bünné változik át. Utóbbinak utalnia kellene a büntelenség pozitív 
lehetőségére, míg az ártatlanság a jogi logikában kizárólag negatívan értelmeződik, mint „nem-büntetendőség”. Pozitív meghatározása nincs, nem változtatható pozitív jogi ténnyé. Attól, hogy valakit nem ítélnek el, a szó valódi értelmében még nem válik ártatlanná, még pontosabban büntelenné: csak büntetlenné. A büntetlen nem jelent valójában ártatlant. A jog rendjében (ahogy a sorséban is, de másképp) az ártatlanság a végső soron megsemmisítendő kivétel. Persze, „ideális” esetben, amennyiben ez mindent átható realitássá válna, úgy a jogi logika jogi tautológiává teljesülne be, és felszámolná önmagát: puszta totális büntetésvégrehajtássá változna; ezt az „eszményt” a legnagyobb hatékonysággal feltehetőleg a nemzetiszocialista megsemmisítő-táborok közelítették meg. A modern büntetés-végrehajtás jogi aspektusból tekintve a „szabadságot” is kizárólag negatív módon definiálja és szankcionálja; ennek legnyilvánvalóbb jele, hogy a nyugat-európai felvilágosodást követő büntetőügyi reformkorszak nyomán a büntetés-végrehajtás általános formája a szabadságvesztés (izoláció) lett, melyre azonban történelmi tehertételként rátelepedett és neki mintegy pozitív tartalmat adott a javító-nevelő („,reszocializáló”, stb.) funkció.

A sors fogalma a szép ideájának konstellációjába tartozik. A sors tehát elsősorban esztétikai kategória, ezért is indokolt első és meghatározó nyitásban a müvészet területe felől közelíteni a sorsfogalomhoz. Ez az összefüggés indokolja azt is, hogy dolgozatom terjedelmileg legnagyobb részét egy irodalmi mű értelmezése, valamint két film elemzése teszi ki (a Sorstalanság címü könyvről, valamint a Hunger és föképp az Antichrist címü filmről lesz szó). A fő vezérfonál ezekben az elemzésekben mindvégig a sors-, valamint a vele korreláló bünmotívumok áttekintő értelmezése (a Hunger képez némileg kivételt, mert az az elemzés az erőszak tematikáján belül a sztrájk fogalmának apropóján kerül elő). A sors fogalmának és a szép ideájának közös eleme, hogy lényegi, és nem pusztán járulékos elemük a látszat. A sorsban a látszat uralkodik. Ami a sors szférájában a feladatként, 
feladványként tételeződő rejtély, az orákulum jóslata, az a szép hatáskörének magasabb rendü területén a megőrzendő titok. Mind a rejtély, mind a titok az igazságra vonatkozik. De míg a sors rejtélyét meg- és feloldó tragikus hős elnémul az igazság kimondhatatlansága előtt, addig a szép ideájának legmagasabb rendű megformálhatósága megőrzi a kifejezés nélküli, a kimondhatatlan, röviden a csend titkát. Magánszemélyek közötti kapcsolatban ennek a megformálhatóságnak a legközelebbi analógiáját talán a tapintat kifejezései adhatják. A látszat szertefoszlása a sors (és az attikai tragédia intenciói szerint gyakran egyidejüleg a hős) megsemmisülését hozza magával, míg a szép mint látszat háttérbe vonul. A sors negatívan, parazita-módon kötődik a boldog élet eszméjéhez, melyet a szép ideája tartalmaz reményként vagy sejtelemként. Ezért is füződik oly gyakran sorsmotívum a szerelem képzetéhez, amely a boldog élet legmagasabb rendủ megformálódásának lehetőségére utal; egészen addig uralja a sors, akár pusztán látens módon, amíg a szép látszat lényegi marad benne. Ahol boldogság van, ott felfüggesztődött a sors hatalma, többek között ezért is nevezi Hölderlin sorstalanoknak a boldog isteneket ${ }^{1}$.

\footnotetext{
${ }^{1}$ Ihr wandelt droben im Licht

Auf weichem Boden, selige Genien!

Glänzende Götterlüfte

Rühren euch leicht,

Wie die Finger der Künstlerin

Heilige Saiten.

Schicksallos, wie der schlafende

Säugling, atmen die Himmlischen;

Keusch bewahrt

In bescheidener Knospe,

Blühet ewig

Ihnen der Geist,

Und die seligen Augen

Blicken in stiller

Ewiger Klarheit.

Doch uns ist gegeben,

Auf keiner Stätte zu ruhn,

Es schwinden, es fallen

Die leidenden Menschen

Blindlings von einer

Stunde zur andern,

Wie Wasser von Klippe

$\mathrm{Zu}$ Klippe geworfen,

fahrlang ins Ungewisse hinab.
} 
Ami a sorsfogalom definícióját illeti, a legpontosabb és legtömörebb meghatározást Søren Kierkegaard adja meg: a sors szükségszerüség és esetlegesség egysége ${ }^{2}$. Ez a kijelentés tovább már nemigen elemezhető. Algebrai tömörségével és áttetszőségével is azonban pusztán csak egy mozaikját képes adni a sorsfogalom megközelítésének, melynek a következőkben kibontakozó sztereoszkópikus tárgyalása mindig újabb és újabb aspektusát próbálja majd tisztázni. És amennyiben belátjuk, hogy a sorsfogalomhoz eltéphetetlenül hozzátartozik egy neki megfelelően némileg korlátozott, lényegében azért mégsem meghatározható természeti-eredendő bünfogalom, akkor ez egyben azt is jelenti, hogy a sorsfogalom sem fogható be sohasem egy definíció alá maradéktalanul, már csak azért sem, mert a sorshoz köthető jelenségek lényegi vonásának bizonyul majd elemi két- vagy többértelmüségük.

Ami ezen a ponton már látszik: ez azt is jelenti, hogy a szabadság és a bün filozófiailag érvényes megközelítésekor még analogikusan sem alkalmazhatóak a szükségszerüség és esetlegesség kategóriái. Ez utóbbiak a természeti, esztétikai, fenomenológiai szférára vonatkoztatható kategóriák. De éppen a kettő szféra keveredése miatt érdekes a sors, amelynek ez a keveredés egyben érdeke is.

A dolgozat célja a sorsfogalom kritikai tárgyalása. Ez a vizsgálódástól filozófiai, jog- és még inkább történelem- és művészetfilozófiai jelleget követel meg. Újabb kritikai részeredmények elérésére éppen utóbbi két terület határvidékén törekszem: azon a

(Tandori Dezső fordításában: „Fönt jártok ti a fény / puha földjén, boldog Géniuszok! / Sugárzó isteni szellők / éringetnek titeket: szent / húrokon így művésznő / ujja ha játszik. // Sorstalan, így, alvó csecsemőként / lélegeznek az égiek, / szüzi-szerényen, / bimbón őrzik: / múlhatatlan / virul ott a szellem, / boldog szemeikből / pillant csöndes, / tiszta öröklét. // Nékünk más adatott. Ne lehessen / nyugvásunk helye. / Tünnek, buknak / a szenvedők, / vakon, egy / óráról a másra, mint / a víz verődik / kőről kőre, / éveken át a bizonytalanba.”)

${ }^{2}$ Søren Kierkegaard: A szorongás fogalma. Ford. Rácz Péter. Göncöl, 1993. p. 115. 
teljességében soha nem feltérképezhető szürke területen, ahol a sors fogalma a történelem és a művészet kölcsönhatásába kerül, vagy épp ezt a kölcsönhatást eredményezi.

A „,módszert”, vagy inkább megközelítésmódot illetően két több-kevesebb erővel ható eredőt tudok megemlíteni.

Az első az elnevezésében sok félreértésre okot adható kritikai „módszer”. Ez az elv első megközelítésben pusztán annyit jelent, hogy a jelenségek vizsgálata során mindig igyekszem elfogulatlanságra törekedve megkülönböztetni a valóban különböző aspektusokat és a nekik megfelelő fogalmi elemeket. Ismeretes, ahogyan A tiszta ész kritikája kidolgozza a dogmatizmus és a szkepticizmus (relativizmus) parttalan vitáját megszüntető transzcendentális kritikai módszert. Amennyiben a gondolkodásnak lehet módszere, és bizonyos mértékig lehet, annyiban a legmeggyőzőbb módszer a Kant által kiteljesített szókratészi-platóni, kritikai módszer. Ám itt nagyon fontos kitétel az „amennyiben”. Feltehetőleg pontosabb volna kritikai gondolkodásmódról, mintsem módszerről beszélni. ${ }^{3}$ És azt sem szabad feledni, hogy a gondolkodás jóval sokrétübb, hogy ne mondjam, szabadabb annál, minthogy bármilyen módszer vagy akár gondolkodásmód

\footnotetext{
${ }^{3}$ A kanti kritikai gondolkodásról hasznos összefoglalást ad Hannah Arendt Kant politikai filozófiájáról szóló előadásaiban: Hannah Arendt: „Előadások Kant politikai filozófiájáról”. Ford. Pató Attila. In Hannah Arendt: A sivatag és az oázisok. Budapest, Gond-Palatinus, 2002. 272-289. (Ötödik és Hatodik összejövetel.) A 282-3. oldalakon olvashatjuk: ,[Kant] világosan megmondta, hogy >>szókratészi módon<< kíván haladni, s hogy a vitapartnert $>>$ tudatlanságának napnál világosabb bizonyításával $<<$ hallgattatja el. Szókratésszel ellentétben hitt a > jövendő metafizika << rendszerében, ám végül az utókorra mégsem rendszert, hanem Kritikákat hagyott örökül [idézetek A tiszta ész kritikájából, B XXXI, 42.o., ill. 45. o. Ford. Kis János. Budapest: Atlantisz, 2009.].” Általánosabb érvényben tárgyalja a kritika kérdéskörét Michel Foucault tanulmányában. Szerinte a modern nyugati gondolkodást körülbelül a XV-XVI. század óta egy „kritikai attitüdnek” nevezheto” gondolkodás-, beszéd- és cselekvésmód jellemez. A kritikai attitűd erényként jelenik meg ebben a hagyományban. "After all, critique only exists in relation to something other than itself: it is an instrument, a means for a future or a truth that it will not know nor happen to be, it oversees a domain it would want to police and is unable to regulate. All this means that it is a function which is subordinated in relation to what philosophy, science, politics, ethics, law, literature, etc., positively constitute. And at the same time, whatever the pleasures or compensations accompanying this curious activity of critique, it seems that it rather regularly, almost always, brings not only some stiff bit of utility it claims to have, but also it is supported by some kind of more general imperative - more general still than that of eradicating errors. There is something in critique which is akin to virtue. And in a certain way, what I wanted to speak to you about is this critical attitude as virtue in general.” Michel Foucault: "What is Critique?". In Rabinow, Paul and Rose, Nikolas ed.: The Essential Foucault. Selections from The Essential Works of Foucault 1954-1984. New York: The New Press, 2003. pp. 263-264.
} 
végérvényesen pályára állíthassa. ${ }^{4} \mathrm{~A}$ módszer pályája Kantnál világosan valamiféle szintézis felé gravitál, azonban tézis és antitézis között elgondolhatóak még más viszonyok is.

A nyelvi és gondolatritmikai aspektus tekintetében, a fentiekben kifejtett fenntartásoknak megfelelően is, a polifónia elve a meghatározó. Ez a maga módján egy szerény javaslat is volna a bölcseleti jellegü értekező prózai forma egyik (újra) bevezetendő alapelvéül. Mihail Bahtyin a zenemüvészetből az irodalmi müvekre transzponált terminusa termékeny területre találhat, a szükséges módosításokkal, strukturális-poétikai alapelvként alkalmazva a bölcseleti értekező próza területén is. Ezen a területen a többszólamúságot előirányzó alapvető technika az ellenpontokra épülő idézet-, parafrázis- és invenció-montázs. A polifónia alkalmazásának fő megnyilvánulása ebben az esetben az idézett szövegek eredeti szövegkörnyezetüktől óhatatlanul megfosztott, átalakuló, sérült önállóságának sértetlenül hagyása, valamint a dolgozat „saját” szövegével és egymással való egyenrangú ellenpontozása (zeneileg ennek az elvnek leginkább talán a korareneszánsz kórusművek kínálhatják legpontosabb analógiáját, például a cantus firmus polifóniáiban). Ez nem jelenti az idézetek kritikátlan alkalmazását, sem a szövegek minőségének és az álláspontoknak a nivellálását. A polifónia elve éppen a szólamok egyediségének folyamatos, azonban együttes és egymásra reagáló megtartását jelenti. Az egymásra reagálás reményeim szerint gondolkodást inspirálóan jelentkezik majd a felmerülő terminológiai kereszteződésekben és mutációkban is.

Természetesen a fentiekben kifejtettekkel együtt korántsem gondolom, hogy munkám bármilyen módszertani (vagy egyéb) tekintetben úttörő jellegü volna. Az elvek utalásszerü

\footnotetext{
${ }^{4}$ A német koraromantika művészetkritika fogalma felől közelít a problémához disszertációjában Walter Benjamin: „A következőkben a kritikáról mint mükritikáról [Kunstkritik] lesz szó, s nem mint ismeretelméleti módszerről és filozófiai álláspontról. A szó, mint majd megmutatjuk, közvetlenül Kant után vette föl egykor ezt az utóbbi jelentését, s ezoterikus terminusként az egyedülálló és tökéletesen kidolgozott filozófiai álláspontot jelöli, az általános nyelvhasználatban azonban csak a $>>$ megalapozott ítéletalkotás $<<$ jelentésében jutott érvényre." Walter Benjamin: A mükritika fogalma a német romantikában. Ford. Ábrahám Zoltán. Bp.: Gond-Cura Alapítvány - Új Palatinus-Könyvesház Kft., 2004. 12. o. W.B.: G.S. I, 13.
} 
megemlítése csak arra hivatott, hogy a formát már kezdettől fogva lehetőség szerint áttetszővé tegyék, és a dolgozat gondolatmenetét ekképp minden ezoterikus igénytől mentessé nyilvánítsák. Az igazsághoz való elfogulatlan hüség és az érthetőségre, világosságra való törekvés közötti nehéz egyensúly megközelítését és viszonylagos fenntartását hivatottak szolgálni a röviden bemutatott elvek.

Amennyiben szeretnénk többek között és először is azt megérteni, miképpen uralkodik többé-kevésbé az önmagán túlnövő, jóllehet, jórészt balladai homályban, artikulálatlan sejtésekben felsejlő sorsképzet nemcsak a totális állam kimunkálására tett nemzetiszocialista és államszocialista kísérleteken, hanem a modern állam, a demokratikusnak is nevezett jogállam mindenfajta létrejött formáján, rendkívül inspiráló, és alighanem nélkülözhetetlen is felidézni Walter Benjamin ebben az irányban kifejtett munkásságának főbb elemeit. Dolgozatom alapvető problémafelvetéseit sok esetben ennek a munkásságnak a sokszor csírában maradt, más esetekben kifejtettebb formára hozott tendenciái is motiválták. Walter Benjamin életművének első szakaszában, egészen $A$ német szomorújáték eredetéről szóló habilitációs dolgozatnak szánt nagyszabású munkájával bezárólag, a sorsfogalom tisztázása központi szerepet foglalt el. Rejtettebb utakon-módokon azonban az életmű egész szövetén vörös szálként húzódik végig ennek a fogalomnak a komplex problematikája, egészen a Passzázsok befejezetlenül maradt feljegyzéshalmának elemeiig, valamint $A$ történelem fogalmáról szóló kéziratban fennmaradt esszéjéig. Dolgozatom járulékos célja többek között az is, hogy a Benjamin-életmüben elszórtan vagy lappangva fellelhető sors-utalások értelmező áttekintését elvégezze. 


\section{ELSŐ RÉSZ}

(Sorstalanság)

Da ich ein Kind war, da redete ich wie ein Kind...

Pál apostol első levele a Korinthusbeliekhez, 13:11

(Luther Márton fordítása)

Da ich ein Kind war,

Nicht wusst', wo aus, wo ein,

Kehrte mein verirrtes Aug ‘

Zur Sonne, als wer drüber wär ‘

Ein Ohr, zu hören meine Klage,

Ein Herz wie meins,

Sich des Bedrängten zu erbarmen.

Johann Wolfgang Goethe: Prometheus 


\section{Jog/erőszak}

A modern, demokratikusnak nevezett jogállam eröszak-monopóliuma olyan tény, amelyet nemcsak nap mint nap tapasztalhatunk, hanem amelyet mindegyik, önmagát a legkevésbé is komolyan vevő állam- és társadalomelmélet evidenciaként kezel. Más kérdés, hogy ezek az elméletek és a kortárs gyakorlat miképpen legitimálja (e terminus már jelzi is a probléma gyökerét) ezt a monopóliumot (a demokratikusnak nevezett jogállamokban ezt a legitimációt államjogi szempontból az alkotmány biztosítja).

A modern legitimációs kísérletek közös társadalomelméleti nevezője a társadalmi szerződés elmélete, mely a népfelség elvének igyekszik közjogi kereteket biztosítani. A társadalmi szerződés elmélete a „társadalmi szabadság” (a közjó) biztosításának céljából az „egyén szabadságának” (amely e felfogás szerint „értelemszerüen” erőszakos formát is ölthet) az ésszerű korlátozására tett kísérletek államjogi eredője. Az európai társadalomtörténetet tekintve annak a kornak, a XVIII. század második felének és a XIX. századnak a terméke a szerződés általánossá és részben, jóllehet ellentmondásos módon, gyakorlattá is váló elmélete, mely a személyes, monarchikus, önmagát reprezentáló hatalom felől a demokratikusnak nevezett reprezentatív közhatalom felé tartó többlépcsős átmenet során ,„a büntetés hatalmának új gazdaságtanát és új technológiáját”5 teremtette meg. Az elkövetkező büntetőügyi reformkorszakot megelőlegezve Jean-Jacques Rousseau híres alapművében, a második könyv ötödik fejezetében az élet és halál jogáról szólván kertelés és szépítés nélkül kimondja az alapelvet: „minden gonosztevő azáltal, hogy a társadalmi szerződést megsérti, büncselekménye következtében lázadó és hazaáruló, a törvény megsértése által többé nem tagja a társadalomnak, sőt nyílt háborút visel ellene. Ebben az

\footnotetext{
${ }^{5}$ Michel Foucault: Felügyelet és büntetés. A börtön története. Ford. Fázsy Anikó és Csürös Klára. Budapest: Gondolat, 1990 (1975). 120.
} 
esetben önfenntartása összeegyeztethetetlenné válik az állam fenntartásával, az egyiknek el kell pusztulnia, és ha a bünöst kivégzik, úgy nem elsősorban mint polgár hal meg, hanem mint ellenség”. ${ }^{6}$ Ez a „törvényen kívüli” bünöző klasszikus formulája. Ez a kívüliség azonban ellentmondásossá válik, mert a büntetés aktusában, mint büntetett, a bűnöző homályos módon mégis „,visszakerül” a társadalomba. A társadalmi szerződés elméletéből származó új büntetőpolitikai gazdaságtan alaptétele szerint ugyanis ,,a legkisebb büntett is az egész társadalmat támadja meg; és az egész társadalom - beleértve a bünözőt - jelen van a legkisebb büntetésben is. A büntetöügyi bünhődés tehát általánosított funkció, a társadalom testével és minden egyes elemével azonos kiterjedésü."7 A társadalmi szerződés révén létrejövő állam erőszak-monopóliuma valóban, a szó régebbi keletű, homogenizáló tendenciájú jellegében „demokratikus”: a társadalom egészére és annak minden szférájára érvényes. (Még ha többnyire látens módon is, de totális. Bár a felvilágosodás és a francia forradalom reformerei az általános funkció teljesítését másképp, büntény-specifikus és nyilvános büntetés-végrehajtás révén képzelték el vagy még inkább álmodták meg ${ }^{8}$, a XIX. századtól napjainkig a lappangó mindenütt-jelenlevőséget mégis inkább a felügyelet, elsősorban az igazságszolgáltatási-bürokratikus szervek és a rendőrség, valamint az általuk foganatosítható szankció révén a formájában szintén homogenizált, egydimenziósított

\footnotetext{
${ }^{6}$ Rousseau, Jean-Jacques: Társadalmi szerződés. Ford.: Radványi Zsigmond. Budapest: Phönix-Oravetz, 1947, 46-7. o. Ez a felfogás nyilvánvalóan tudatos bünelkövetőt, a szerződést tudatosan megszegöt feltételez. De innen származik többek között az a modern alapelv is (amely kísértetiesen, oidipuszi módon sorsszerü), hogy a törvény nem ismerése sem ment föl a büntetés alól (a pszichiátriailag és ezáltal jogilag is definiált pszichopatológiai esetek csak látszólagos kivételek, hiszen az alapformát, a szabadságvesztést/izolációt azok is örzik). A Josef K.-t letartóztató örök egyike már A per első fejezetében utal ennek az alapelvnek a hatáskörére: „Franz is hozzátette a magáét: - Látod, Willem, bevallja, hogy nem ismeri a törvényt, és ugyanakkor azt állítja, hogy ártatlan.” In Franz Kafka: A per. Ford. Györffy Miklós. Palatinus, 2002. 20.

${ }^{7}$ Foucault, i. m., 120.

${ }^{8}$ A börtönbüntetésről mint általános büntetés-végrehajtási formáról a „19. század első éveiben még tudják, hogy új keletü; de oly erösen és olyan mélyen összefügg a társadalom müködésével magával, hogy hamar feledésbe merül minden másfajta büntetés, amit a 18. század újítói kitaláltak.” (Foucault, i.m., 316.) Az indoklás kissé elnagyolt; nyilván nem ez az egyébként kétségtelenül fennálló összefüggés volt az egyetlen ok, amiért feledésbe merültek az ,újítók” alternatív büntetésformái (gondoljunk például néhány elmés ötlet kivitelezési nehézségeire és gazdaságossági buktatóira).
} 
büntetés, a szabadságvesztés fenyegetése biztosítják ${ }^{9}$. A totalitáriusnak nevezett államok éppen azért kaphatták ezt a megkülönböztető jelzőjüket, mert minden életszférában és élethelyzetben nyilvánvalóvá akarták tenni a „normális” demokratikus viszonyok között többnyire pusztán lappangó erőszak-monopólium jelenlétét. Többek között ebből fakad az az atavisztikus és anakronisztikus félelmi görcs is, mely a legismertebb diktátorok és végrehajtó epigonjaik eltorzult, túlméretezett vagy éppen elfogódott uralkodói, „hamis monarchai” gesztusaiban érhető a legkönnyebben tetten.) Szorosan összefügg ezzel a totális tendenciával és annak kizáró jellegü hatásaival az, ami miatt ellentmondásosnak neveztem a társadalmi szerződés részleges gyakorlati megvalósulásait. Ahogyan azt Carl Schmitt $A$ parlamentarizmus és a modern tömegdemokrácia ellentéte című 1926-os írásában a modern tömegdemokrácia fogalma kapcsán kifejti, két elem, a demokratikus államforma és egy „individuális-humanitárius erkölcs és világnézet” inkoherens és homályos összekapcsolása jellemzi eredendően Rousseau elképzelését. „Úgy tünik, a Rousseau-val való minden foglalkozás és ama helyes felismerés ellenére, mely szerint Rousseau a modern demokrácia kezdetén áll, még nem vették észre, hogy már a Társadalmi szerződés államkonstrukciója is inkoherens módon egymás mellett tartalmazza ezt a két különböző elemet. A homlokzat liberális: az állam jogszerüségének a szabad szerződésre történő alapozása. Azonban az ábrázolás további menetében és a lényegi fogalom, a volonté générale kifejtése során megmutatkozik, hogy az igazi állam Rousseau szerint csak ott létezik, ahol a nép olyan homogén, hogy lényegében egyhangúság uralkodik. A Társadalmi szerződés szerint az államban nem létezhetnek pártok, különérdekek, vallási különbözőségek, tehát semmi olyan dolog, amely elválasztja az embereket egymástól, így még pénzügyek sem. [...] [Rousseau] egészen komolyan mondja: a pénzügy rabszolgáknak való dolog, egy mot d'esclave

\footnotetext{
${ }^{9}$ Foucault ezt a „fordulatot” egyértelmüen a XVIII. és a XIX. század fordulójára teszi: „A két század fordulóján egy új törvénykezés úgy határozza meg a büntetőhatalmat, mint a társadalom általános funkcióját, amelyet minden tagja fölött egyformán gyakorol, és amelyben mindenki egyaránt képviselve van; de azzal, hogy a szabadságvesztést teszi meg az alapvető büntetésnek, a hatalom egy sajátos típusának jellegzetes uralomgyakorlási eljárásait vezeti be.” (Foucault, i.m., 316.)
} 
(Társadalmi szerzödés III. könyv, 15. fejezet, 2. szakasz). Ennél azt kell figyelembe venni, hogy Rousseau-nál a $>$ rabszolga $<<$ szónak súlyos következményekkel járó jelentése van, amely a demokratikus államkonstrukcióban járul a szóhoz; a szó a néphez nem tartozót, a nem-egyenlőt, a nem-citoyent jelöli, akinek semmit sem használ, hogy in abstracto $>>$ ember $<<$, a heterogént, aki nem vesz részt az általános homogenitásban és ezért joggal zárják ki." ${ }^{10}$ Vagyis Schmitt értelmezéséből kiindulva Rousseau-nál a „rabszolga” lényegében megegyezik az ellentmondásosan törvényen kívüli, társadalmilag heterogén, kizárandó, ám, mint Foucault-nál láttuk, végső soron mégsem ki-, legfeljebb bezárható bűnözővel.

Az erőszak-monopóliumot közjogilag biztosító alkotmány kapcsán engedjenek meg egy rövid kortársi helyzetre vonatkozó kitérőt.

A közelmúlt magyarországi politikai eseményei világosan rámutattak az alkotmányozás meröben hatalmi-konstruktiv (,, homlokzati”) oldalára és egyúttal arra is, hogy a jogfenntartó eröhatalom (jelen esetben a kormány által jórészt ellenörizhetetlenül képviselt állam) reflektálatlan hatalmi alkotmányozása, az erőszakos jogteremtés abban a formában, hogy az végsö soron a „,rendszeren”, a modern demokratikusnak nevezett jogállam keretein belül is kíván egyúttal maradni, éppen az e kormány által aktuálisan képviselt államhatalom legitimációját biztositó jogteremtő erőhatalmat gyengíti. Az alkotmány és a politikai eröhatalom legitimációjának ellentmondásos (konstruktiv) eredetére túl éles fény vetül így. A kortárs magyarországi politikai hatalom filozófiai értelemben szélsőségesen vak a saját legitimációját, a saját hatalmi támasztékait illetően. Magában az „,ideális” esetben sem

\footnotetext{
${ }^{10}$ Carl Schmitt: „A parlamentarizmus és a modern tömegdemokrácia ellentéte”. In uö: A politikai fogalma. Ford. Cs. Kiss Lajos. Budapest: Osiris - Pallas Stúdió - Attraktor, 2002. 201.
} 
ellentmondásmentes modern demokratikus jogrendben keletkezett így egy újabb, alapvetö ellentmondás. És keletkezik is szinte nap mint nap az újabb és újabb alkotmánymódositások révén. A belső konfliktusos helyzetet semmi sem jellemzi jobban és hitelesebben, mint Sólyom László volt köztársasági elnöknek és az 1989 utáni Alkotmánybíróság első elnökének nemrégiben, még az úgynevezett alaptörvény beiktatása után nem sokkal elhangzott beszéde a Történelemtanárok Egyletének konferenciáján: „Az alkotmány nem új, illetve nem az alkotmány új, hanem az alkotmányos hozzáállás. Az elmúlt húsz évben kialakult kultúrában az alkotmány szent. Úgy néz ki, már nem szent, hanem csak egy eszköz, ami hihetetlen visszaesés.” Később arról beszélt Sólyom László, hogy a struktúrák területén hatalmas rombolást visz végbe a kormány hozzáállása, amely szerint „, nem áll az utunkban semmi, még maga az alkotmány sem." "11 Kultúránkban a szükebb, szakmai értelemben és nem propagandisztikus-pártpolitikai értelemben vett közjogi beszédmód ritkán kölcsönöz jelzőket a vallási terminológiából, két jellemzö kivétel azonban adódik: az alkotmány szent, valamint a magántulajdon szent és sérthetetlen. A félelem civilizált, kapitalista, összkomfortos természetrajzához is érdekes adalékként szolgálhat ez a terminusalkalmazási tendencia.

$* * *$

A közös társadalomelméleti nevezőhöz képest az állami erőszak-monopólium legitimációs kísérleteinek a közös történelmi nevezője messzebb, egészen a történelem előtti (az írott jog elötti) időkbe vezet vissza. A probléma világos kibontása érdekében óhatatlanul történelemfilozófiai vizekre kell evezni.

\footnotetext{
${ }^{11}$ Népszabadság, 2011. október 10.
} 
Walter Benjamin Az eröszak kritikájáról szóló 1921-ben publikált írásában ${ }^{12}$ a jog és az erőszak történelem előtti, mitikus eredetét igyekszik feltérképezni. Módszertani kiindulópontként a jogfilozófia két nagy irányzatát különbözteti meg: az egyiket természetjognak, a másikat pedig pozitív jognak nevezi. Ez a megkülönböztetés természetesen közkeletünek mondható. A következtetések és értelmezések már kevésbé. Benjamin gondolatmenete úgy indul, hogy kifejti: a természetjog felfogása szerint az erőszak ,természeti képződmény, szinte valami nyersanyag, fölhasználása tehát nem rejt magában semmi problémát, hacsak nem élnek vissza vele igazságtalan célok érdekében”. Benjamin mintegy mellékesen megjegyzi, hogy ez volt ,a terror ideológiai alapja [...] a francia forradalom idején”. Hozzátehetnénk: ezek szerint minden forradalmi terror ideológiai alapja természetjogi eredetü. Már amennyiben ennek a szókapcsolatnak, hogy „forradalmi terror”, van értelme: Benjamin esszéjének éppen az az egyik fő ambíciója, hogy kirajzolja egy olyan forradalmi erőszak lehetőségét, amely „tiszta”, nem terrorizáló, nem szankcionáló, nem alapít államot vagy jogot, és nem vindikál hatalmat. És ennyiben, a szó ideális értelmében, csak ilyen forradalmi erőszak (Gewalt) létezhet, ám „forradalmi terror” nem. Más a helyzet az ellenforradalmi-állami terrorral, mely a maga szankcionált erőszakmonopóliumára hivatkozik - ezt a pozitív jog erőszak-elve biztosítja számára. És rendszerint emiatt ezt az erőszak-alkalmazást, megfordítva vagy pervertálva a fentebbi gondolatmenet logikáját, az éppen kortárs hatalom-konformista közbeszéd nem is nevezi terrornak. Felvethető volna egyébként, ahogyan fel is vetették már néhányan, hogy a francia forradalom nem éppen abban a pillanatban szünt meg forradalmi lenni, amikor terroruralommá vált. Ha ezt elfogadjuk, akkor Benjamin odavetett megjegyzése is sántít, hiszen éppen nem természeti képződményként, hanem szankcionált, jogos hatalmi cselekményként, vagyis pozitív jogi tényként tüntették fel Robespierre-ék az erőszakot.

\footnotetext{
${ }^{12}$ Walter Benjamin: „Az erőszak kritikájáról”. Ford. Bence György. In Walter Benjamin: Angelus Novus. Ford. Bence György et al. Magyar Helikon, 1980 (1921). 25-56. W.B.: G.S. II, 177-
} 
A pozitív jog ugyanis a természetjogi elvvel szemben úgy véli, hogy ,az erőszak történelmileg jön létre” (29). Nem a természetből nő ki. A pozitív jog különbözteti meg tehát elvileg is a szankcionált, történelmileg elismert és a nem szankcionált eröszakot. Az állami erőszak-monopólium jogi megalapozásának eredete itt lelhető fel: mint azt már futólag említettem, Benjamin alapfeltevése szerint a modern jog minden olyan megnyilvánulást próbál meggátolni, amelynek során az egyén vagy a kisebb közösség a saját természeti céljait („szabadságát”) erőszakos úton próbálja érvényesíteni. A kérdés az, hogy miből fakad az értelme ennek a megkülönböztetésnek törvényes és nem törvényes erőszak között:

„A jognak nem azért érdeke monopolizálni az erőszakot az egyénnel szemben”, írja Benjamin, „mert a jogi célokat akarja biztosítani, hanem azért, mert magát a jogot akarja biztosítani. [... A]z eröszak, amennyiben nem a mindenkori jog kezében van, nem az általa elérhető célok révén fenyegeti a jogot, hanem már pusztán azzal, hogy a jogon kívül létezik." (31-2)

A jogon, a későbbiekben kifejtendő „sorsszerü renden” kívül létező erő(szak) az, amely új hatalmat, új jogot képes megalapozni. Ennek archetipikus alakja Prométheusz; és társadalomlélektani vonatkozásban a „nagy bünözők” feletti népi csodálatnak megannyi megnyilvánulása is ide vezethető vissza: a csodálat tárgya a „nagy bünöző” „heroizmusa”. Prométheusz „fenséges bátorsággal kihívja a sorsot [Schicksal], váltakozó sikerrel harcol ellene, és a monda meghagyja Prométheusznak a reményt, hogy egyszer majd új jogot ad az embereknek" (49). Ebből világosan látszik, hogy a mitikus-esztétikai gondolkodás és a heroizmus csodálata foglya marad a sors-elképzelésnek (hiszen harcol is ellene): a prométheuszi archetípus nem eltörölni akarja a jogot, hanem új jogot akar teremteni. A 
tragikus hős dacos ellenállásában, hallgatásában, szenvedésében és/vagy halálában is ott rejlik a szerződés elméletének csírája. A német szomorújáték eredetében érinti bővebben ezt az összefüggést Benjamin: „Egyedül az őskor [die Vorzeit] ismerhette azt a tragikus hübriszt, mely a hős életével fizeti meg a hallgatás jogát. A hős, aki visszautasítja, hogy igazolja magát az istenek előtt, szinte azt mondhatnánk, olyan szerződésszerü vezeklő eljárás révén egyezik ki az istenekkel, mely kettős jelentése szerint, egy régi jogszabálynak nemcsak helyreállításával, hanem elsősorban aláásásával egyenlő a megújult közösség nyelvi tudatában. Harci játék, jog és tragédia, a görög élet nagy, agonális hármassága - az agónra mint sémára mutat rá Jacob Burckhardt Görög müvelödéstörténet-e - egyesül a szerződés jegyében."13

A nagy köztörvényes és politikai bünözők pedig öntörvényüek próbálnak lenni, de úgy tünik, hogy ez önmagában (az öntörvényüség tartalmától eltekintve) csak anakronisztikus árnyéka a szabadságnak, mely utóbbi csakis a jogtól, a sorsszerü rendtől teljesen függetlenül, vagy talán pontosabban: attól idegenül, attól idegenkedve, azt mintegy megszüntetve (és szigorú értelemben nem az ellen) alakulhat ki. Kertész Imre Sorstalanság címü könyvének lezárásában is ebben a probléma-komplexumban találja magát az olvasó. Kissé elébe vágva a később következő részletes elemzésnek, kiemelek itt egy kulcsfontosságú jelenetet, amelyet természetesen a könyv értelmezői is rendszerint ki szoktak emelni.

${ }^{13}$ Walter Benjamin: „A német szomorújáték eredete”. Ford. Rajnai László. In Angelus Novus, 305. W.B.: G.S. I, 292. Ld. még ehhez Johann Huizinga: Homo ludens. Kísérlet a kultúra játék-elemeinek meghatározására. Ford. Máthé Klára. Bp. Athenaeum, 1944. „Játék és háború” c. fejezet: 98-114. 
Köves Gyuri a Sorstalanság ${ }^{14}$ föszereplöjeként a fentebb ismertetett belátást tételesen fogalmazza meg két izig-vérig kispolgár (szinte csak, még a történelmi körülményeket figyelembe véve is, mellékesen zsidó) vitapartnerének (meg is jegyzi kissé sajnálkozva az elbeszélő nem sokkal később: „, De hát ők voltak most itt, ők vannak-e percben legalább igy rémlett szinte - mindenütt”), a Köves név kísérteties/mitikus alakváltozatát viselö „öreg” Steinernek és elmaradhatatlan társának, Fleischmann bácsinak: „ha sors van” mondja nekik Köves Gyuri, ,,akkor nem lehetséges a szabadság; ha viszont-folytattam magam is egyre meglepettebben, egyre jobban belémelegedve -, ha viszont szabadság van, akkor nincs sors, azazhogy - álltam meg, de csak egy lélegzetvételnyi szünetre -, azazhogy akkor mi magunk vagyunk a sors - jöttem rá egyszerre, de oly világossággal e pillanatban, mint ez ideig még soha” (Sorstalanság, 330). A huszadik század leginkább következményterhes, egyszersmind beláthatatlan ígéretet magában rejtő, történelemfilozófiai rétegeket megmozgató gondolata hangzik el ebben a csak látszólag naiv, „, kamaszos” kijelentésben, egyszerü és pontos szavakkal, és formai szempontból a megfelelö szituációba ágyazva - ezért ezekre a szavakra és fogalmakra, valamint a dramatikus szituációra, melyben elhangzanak, a könyv közelebbi kritikai értelmezése során visszatérek majd. Itt csak annyira utalnék még, hogy ez a mozzanat jelenti egyben (és az elöbbiekkel szétbonthatatlan összefüggésben) a könyv formailag legveszélyesebb pontjáthiszen ahogyan az öreg Steiner és Fleischmann bácsi menthetetlennek bizonyuló kispolgári bornirtsága Köves Gyuri immár irodalmi figurájából kiszabadulni látszó, kérlelhetetlen szavaira, úgy leselkedik mindenfelöl a mü eme legtételesebbnek mutatkozó pontjára a didaxis és az olcsó erkölcsi példázatosság veszélye, mely utóbbi egyben azzal fenyeget, hogy az egész müvet magával rántja. A Sorstalanság legnagyobb formai-tartalmi (és nem

\footnotetext{
${ }^{14}$ Kertész Imre: Sorstalanság. Magvető, 2010 (1975).
} 
technikai) érdeme, hogy az elkerülés és megúszás bármiféle szándéka nélkül veti bele magát a veszélynek ebbe az örvényébe.

$* * *$

A prométheuszi archetípus fennálló jogot érintő fenyegetését a modern, felvilágosodás utáni jogrend a hálózatszerüvé váló felügyelet révén saját magába olvasztja: ez a tendencia a „törvényen kívüli” fogalmának a megszünése felé vezet, ahogyan azt Michel Foucault is több helyütt elemzi. „E panoptikus társadalomban, amelynek mindenható armatúrája a bezárás, a bünöző nincs a törvényen kívül; már az elején is benne van a törvényben, mi több, a törvény legeslegközepén vagy legalábbis azoknak a mechanizmusoknak a közepén, amelyek érzéketlenül juttatják el a fegyelemtől a törvényig, a devianciától a törvénysértésig"15. A normába/törvénybe integrált bünözésnek megvan a maga domesztikáló tendenciájú politikai vetülete, ahogyan azt Foucault szintén hangsúlyozza nem egyszer. A modern jogrend a rá nézve fenyegető társadalmi folyamatoknak úgy próbálja elejét venni, hogy integrálja és hasznosítja őket: nemcsak befogadja a „gonoszt”, mint Krisztus, hanem a maga módján stratégiai okokból le is paktál az „ördöggel” - ám az érintett jogalany háta mögött. A modern jog történetében ennek a tendenciának társadalomtörténeti vonatkozásban legmarkánsabb jele a sztrájkjog bevezetése a XIX. és XX. század fordulóján. A korabeli, az 1920-as évek európai jogrendjének rendszerében Benjamin megítélése szerint a nemrég bevezetett sztrájkjognak van a legellentmondásosabb, egyszersmind a legkritikusabb szerepe. Itt fontos megjegyezni, hogy Az erőszak kritikájáról szóló szöveg legfontosabb közvetlen ihletője kétségkívül azoknak az eseményeknek a személyes és politikai-társadalmi vonatkozású tapasztalata, melyek a wilhelminus német

\footnotetext{
${ }^{15}$ Foucault, i.m., 415.
} 
birodalom széthullását, az I. világháború elveszítését követően Németországban a weimari köztársaság kikiáltásáig (beleértve a Spartacus-felkelés vérbefojtását, Rosa Luxemburg és Karl Liebknecht, majd Leo Jogiches sunyi meggyilkolását), és nem sokkal azután lejátszódtak. A Georges Sorel által általános sztrájknak vagy proletársztrájknak ${ }^{16}$ nevezett és közismertté tett utópikus-hatalommegsemmisítő tendenciájú akció történelmi esélyét a korabeli német radikális baloldal képviselői közül Rosa Luxemburg az I. világháború kirobbanását megelőzően, főleg az 1893-as, majd az 1902-es kudarcba fulladó belgiumi általános sztrájkok hatása alatt már 1906-ban megjelent írásában ${ }^{17}$ felvetette (tulajdonképpen Sorel elött, és egyébként nála sokkal világosabban), az I. világháború kirobbanása előtt pedig az árral, többek között saját pártjával, az SPD-vel és a többi parlamenti párt általános militarista propagandájával és politikájával szemben is keresztül akarta vinni. Persze ez nem feltétlenül érinti a jogrendszerben lévő, az elfogulatlan spekuláció számára megnyíló ellentmondás érzékelését, mely Benjamin szövegét áthatja. A parlamentarizmus kritikáját azonban mindenképp. Innen eredeztethető az az alapvető bizalmatlanság és elégedetlenség is a német szociáldemokráciával és a weimari parlamentarizmussal szemben, amely ugyanúgy alapvető inspirációja Walter Benjamin gondolkodásának, mint például a húszas években írott Carl Schmitt-írásoknak is (utóbbiaknak némiképp Benjamin és az általa ebben az írásában bőségesen idézett Georges Sorel írásainak hatására). Walter Benjamin és Carl Schmitt parlamentarizmussal kapcsolatos bizalmatlansága azonban elméletileg és gyakorlatilag is teljességgel ellentétes következményekkel jár, és itt szó sem lehet arról a hamis és felelötlenül hangoztatott közhelyről, mely szerint az ellentétes nézetek kiegyenlítik egymást, vagy netán egymásba

\footnotetext{
${ }^{16}$ Georges Sorel: Gondolatok az erőszakról. Ford. Burján Mónika, Lukács Katalin és Szénási Éva. Századvég, 1994. A könyv első kiadása Franciaországban 1906-ban jelent meg a Mouvement Socialiste nevű anarchoszindikalista folyóiratban.

${ }^{17}$ Magyarul lásd: Rosa Luxemburg: „Tömegsztrájk, párt és szakszervezetek”, in uő: A szakszervezetek és a tömegsztrájk. Ford. Nyilas Vera, Petri György, Rózsa István. Szerk. Hamburger Mihály. Budapest: Táncsics, 1976.
} 
átvezethetők; erre később igyekszem még részletesebben kitérni. Legyen elég ehelyütt annyi, hogy megítélésem szerint rendkívül felelötlen dolog összemosni azt a nem összeegyeztethető ellentétet, hogy míg Benjamin valamiféle eszkatologikus jog-, hatalomés állammegsemmisítésről beszél, addig Carl Schmitt a totális államról és a totális háborúról ábrándozik. Benjamin gondolatmenete szerint mindenesetre ezen a ponton egyelőre arról van szó, hogy a munkásságnak biztosított sztrájkjog révén az állam de jure elismer egy olyan erőhatalmat, amely de facto, egy általános forradalmi sztrájk formájában, magát az államot is képes lehet felszámolni. A hatalmi-politikai állam felszámolási kísérletének ilyen nyomai fedezhetőek fel igen markánsan például az 1956-os magyar forradalomban, vagy az általános forradalmi sztrájk nyilvánvaló jeleit felmutató 1980-as gdański hajógyári sztrájkban Lengyelországban - e nyomok feltérképezése azonban egy másik, vagy éppenséggel több dolgozatot igényelne.

Visszatérve a sztrájkjog bevezetésének anomáliájára: az állam, Benjamin gondolatmenete szerint, a sztrájkjog garantálásával hatalmi szempontból dialektikusan jár el: a sztrájkjog biztosításának ugyanis éppen az a jogi-hatalmi célja, hogy a magára a jogrendre veszélyt jelentő erőhatalmat domesztikálja, mintegy önmagába olvassza. A modern, demokratikusnak is nevezett állam erőszak-monopóliuma, jellemzően paradox módon, csak a sztrájkjog biztosításával, vagyis a nem államilag szankcionált erőszak egy formájának elismerésével lehet formailag és tartalmilag is teljesnek ható. A sztrájkjog elemzése világosan rámutat ennek a jogrendnek az alapvető anomáliájára.

A sztrájkjog abban kivételes Benjamin ebben a kérdésben nagyrészt Georges Sorel-re hagyatkozó érvelése szerint, hogy benne az állam (elviek szerint korlátozott formában, de) megengedi az egyénnek és a nem-hivatalos közösségnek az erőszak gyakorlását. Ennek az erőszaknak a legegyszerűbb és leginkább kisstílű formája a zsarolás: ameddig nem emeled a 
bérem, addig felfüggesztem a munkát stb. Nyelvi-logikai alapformája ennek a zsarolásnak a „ha te (nem) $x$, abban az esetben én (nem) $y$ ”.

\section{Az éhenhalás joga. A Hunger címü filmről}

A sztrájkjog társadalmilag megvalósitható formái közül első látásra talán paradox módon az éhségsztrájk bizonyul a legradikálisabb és az állam eszméje szempontjából a legkritikusabb formának, föként abban az esetben, ha halálig tart. Az éhségsztrájk jellemzöen gyakran a fogvatartottak, azaz a jogaikból leginkább kisemmizettek sztrájkformája. Paradoxnak látszik ez a radikalitás azért, mert itt az egyén vagy közösség eröszak-kifejtése fizikai értelemben maga a sztrájkot végrehajtó egyén vagy közösség, és nem közvetlenül a végrehajtó hatalom birtokosai ellen irányul. Azonban azzal, hogy általa nem csupán valamilyen tevékenység, munka van felfüggesztve, hanem a puszta természeti élet, az éhségsztrájk világosan és felismerhetően rajzolja ki az állam hatáskörének alapját és határait. Mert ez a határ az érzéki-természeti élet határa, és semmiképpen sem érinti a szigorú értelemben vett etikai-szellemi szférát. Ezért, hogy az éhségsztrájk gyakran botránykönek bizonyul. Politikai és erkölcsi értelemben a leghatékonyabban egy olyan kultúra világán belül nyilvánulhatott meg a huszadik századi történelem során az éhségsztrájk, amely társadalom fejlödésének alaptendenciáiban a legelevenebben örzi az aszkézis formáinak gazdag hagyományát és tiszteletét, valamint az ember természeti életének relativ és a végsőkig relativizálható értékét, egyszersmind jótékonyan megfertözödött a tizennyolcadik és tizenkilencedik századi nyugat-európai szabadságmozgalmak „, gonosz”, „,destruktiv”” levegőjével - az 1930-as és 1940-es években függetlenségét kiharcoló Indiára és elsősorban természetesen Gandhira gondolok. 
(Walter Benjamin terminológiájához visszatérve azt lehet mondani, hogy amikor ö forradalmi általános sztrájkról beszél, akkor mindig a halálra való készséget is beleérti, a természeti élet hatalmának teljes felfüggesztését, felszámolását, lerombolását. Vigyázzunk azonban, hogy nehogy összetévesszük a halálra való készséget az egyéni hösködéssel; akkor sem, ha előbbi szubjektív feltételei feltehetőleg sohasem mentesek némi „,romantikától”. Rosa Luxemburg is kitér erre az aspektusra már emlitett, az 1896 és 1906 között a cári Oroszországban zajló forradalmi folyamatok elemzéséböl kiinduló, és a sztrájk általános kérdéskörében alapvetö fontosságú írásában: „Annak a szervezett dolgozónak a lelkiállapotával, aki nem hajlandó munkaszünetet vállalni május elsején, amíg elbocsátása esetére elöre nem biztositanak számára pontosan meghatározott segélyt, sem forradalmat, sem tömegsztrájkot szervezni nem lehet. De éppen arról van szó, hogy a forradalmi idöszak viharában a proletárok segélyt követelö gondos családapából >>romantikus forradalmárrá<< változnak, olyan emberré, akinek a legföbb érték is, mármint az életnem is beszélve az anyagi jólétröl-, elenyészö jelentőségü a harci ideálokhoz képest. ${ }^{18}$ A halál bekövetkezésének, vagy a bekövetkezés esélyének jogi-politikai vonatkozásaira más aspektust érintve még több izben visszatérek, amikor a halálbüntetés jogának jogrendet megalapozó erejét próbálom értelmezni Benjamin nyomán.)

A történelmi köztudatban talán még nem ilyen evidens, hogy a nyugati félteke éhségsztrájkjainak történetében kiemelkedö, a modern jogállam alapeszméjét érintő jelentöségü a Bobby Sands által 1981-ben, a belfasti Maze börtönben raboskodó IRA-tagok körében meghirdetett, tíz halálos áldozatot követelö ételmegvonási akciója. Nem ilyen evidens, mert „ügyük” nem tünik olyan tiszta és tiszteletreméltó ügynek, mint Gandhi

\footnotetext{
${ }^{18}$ Rosa Luxemburg, i.m., 158.
} 
függetlenségi akciói. A jelentőség azonban az ügy természetétöl valójában független. Erre a történelmi jelentöségre világít rá Steve McQueen 2008-ban bemutatott Hunger címü filmje. A Provisional IRA hivatalosan 1981. március 1-jén jelenti be a belfasti Maze börtönben raboskodó tagjainak újabb éhségsztrájkját. A sztrájk célja az, hogy a brit kormány újra ismerje el a PIRA-rabok hat évvel azelött felfüggesztett politikai státuszát. A felfüggesztett politikai státusz követelésének jogi-társadalmi-politikai vetületü motivációja az, hogy a sztrájk megkezdésekor a PIRA tagjai köztörvényes bünözökként vannak fogva tartva. A Provisional Irish Republican Army már elnevezésében is utal arra a jogi-hatalmi dilemmára, amely az itt szembenálló felek, a PIRA és a brit kormány között fennáll: míg az egyik fél szerint háborúról, hadifoglyokról, addig a másik fél szerint (jobb terminus hiján) terrorizmusról és bünözőkről van szó. A huszadik század második felének visszatérö, legtöbbször természetesen nem pusztán jogi-hatalmi vetületü dilemmája ez.

Az 1981. év éhségsztrájkja abban különbözik a megelözőektől, hogy a kezdeményezö Bobby Sands szándéka szerint az éhségsztrájkot vállalók egymáshoz képest kéthetes késéssel csatlakoznak majd az akcióhoz (megelözendö, hogy esetleg haldokló társaik iránt érzett szánalomból felfüggesszék azt), és a tárgyalás vagy kompromisszum minden formáját elvetik: vagy célt érnek, és a brit kormány nemzetközi fórumokon is elismeri a rabok politikai státuszát, vagy éhen halnak. Sands az elsö, aki éhen hal a sztrájk megkezdése utáni hatvanhatodik napon; később kilenc társa követi majd öt a halálba; ezek után a Margaret Thatcher vezette brit kormány a rabok minden tárgyi követelését teljesiti, ám jellemzö módon anélkül, hogy hivatalosan elismerné a politikai státuszt. A 2008-ban készült Hunger címü film hozzávetőlegesen ezt a történelmi anyagot dolgozza bele expozíciójába és alapvetö problémafelvetésébe, a film utolsó harmadában pedig szinte kizárólag Bobby Sands haldoklását viszi szinre: rekonstruálja és megkonstruálja azt. 
A huszadik század második felének hatalmi-politikai közbeszédében közismerten jellemzö és problematikusan használt terminus a „,terror”, ,terrorizmus” és ezek származékai. A huszadik század második felének egyszeri államhatalma legtöbbször arra használja (megint csak: jobb hỉján, és időnként leginkább a kétségbeesettek fantáziátlanságát idézö módon) ezt a terminust, hogy megkülönböztesse a nemzeti és nemzetközi hadseregek, illetve még problematikusabb módon a rendörség és egyéb államhatósági szervek által kifejtett szankcionált, alkotmányosan vagy nemzetközi jogi úton szentesitett eröszakot attól a nemszankcionált, nem-szentesitett, söt a büntetö törvénykezés révén meghatározott és a társadalmi közbeszédben kriminalizálandó eröszaktól, melyet valamely olyan egyén vagy csoport fejt ki politikai céllal, akit vagy amelyet az állam erre nem hatalmazott fel. Az erőszak utóbbi fajtája, melyet ez a mindenkori államhatalom újabban terrorizmusként, időnként még mindig, pontosabb terminussal, államellenes bünként nevez meg, leggyakrabban természetesen éppen valóban ez ellen az államhatalom ellen, esetleg annak megdöntésére irányul. Elfogulatlanul és tisztán elméleti alapról tekintve a „kétfajta” eröszak-kifejtésnek ez az egyértelmünek szánt megkülönböztetése igen gyenge lábakon áll. A terrorizmus terminusának démonikus kétértelmüségét (hogy Benjamin kedvelt fordulatát alkalmazzuk) eddig még kevés államhatalom ismerte fel. Ez a démoni kétértelmüség abból a használatból ered, ahogy a hatalmi politika képviselöi a terror(izmus) szót akár ugyanazon a kontextuson belül vonatkoztatják a jogi-természeti, valamint az etikai szférára, azzal a céllal, hogy sokszor meglehetösen zavaros morális igazolást és fölényt biztositsanak az állami szervek által kifejtett, törvényesen szentesitett hatalmi-politikai eröszaknak. Jogigyakorlati értelemben a terror(izmus) terminus legtöbbször a büntetendö, kriminalizálandó cselekvést választja el a politikai cselekvéstöl (például a szintén eröszakra, jóllehet nemcselekvő eröszakra alapuló sztrájktól és a tüntetéstöl). A jogi-gyakorlati alkalmazás esetére releváns terminus-alkalmazási példa a következö, 1981-böl való sajtókommentár, melyet a 
San Francisco Chronicle munkatársa jegyzett fel Bobby Sands halála kapcsán: „A terrorizmus jóval túlmegy a politikai hitvallás puszta kifejezésén. Nem is lehet rá kompromisszumos megoldást találni, ahogyan azt Nyugat-Európa országai és az Egyesült Államok is beláthatták. Bárok, éttermek, szállodák felrobbantása, bankrablások, prominens közéleti személyek elrablása és meggyilkolása: ezek mind büntettek, melyek megoldása a büntetőjogra tartozik.",19

Ez úgy hangzik, mintha maga Margaret Thatcher mondta volna. Legalábbis majdnem úgy. Van azonban egy fontos és pregnáns különbségtétel ehhez képest Thatcher terminológiájában. Thatcher figurája sok szempontból történelmi határeset. IRA-t érintő megnyilvánulásait olvasva-hallgatva úgy tünik, hogy az Egyesült Királyság korabeli miniszterelnöke tisztában volt ennek a terminológiának a hatalmi-politikai sebezhetöségével, éppen ezért, amint lehet, kerüli a ,terror” és ,,terrorizmus” szavak használatát. Inkább egy régebbi, jól bevált (hiszen bizonyos értelemben vérbeli „,konzervatív” politikusról van szó!) megkülönböztetéshez, a politikai/bünügyi dichotómiához fordul, melyben az egyik minőség kizárja a másikat. A „,terrorizmus” helyett pedig rendszerint a jóval általánosabb ,,eröszak" ${ }^{\text {20 }}$ terminust alkalmazza, ha az állam

\footnotetext{
19 "Terrorism goes far beyond the expression of political belief. And dealing with it does not allow for compromise as many countries of Western Europe and United States have learned. The bombing of bars, hotels, restaurants, robbing of banks, abduction and killing of prominent figures are all criminal acts and must be dealt with by criminal law." "The Death of Bobby Sands", San Francisco Chronicle, 1981. május 6.

${ }^{20}$ Ehelyütt hívnám fel e dolgozatban elsőként a figyelmet arra a sokrétủ vonatkoztathatóságot magába sủrítő nyelvi tényre, hogy a magyar 'eröszak' és hozzá valamelyest hasonlóan az angol (tulajdonképpen latin) 'violence' szónak igen eltérő helyi értéke és hangoltsága van az illető nyelvekben, mint a német 'Gewalt'-nak a magáéban. A problémára bővebben visszatérek. Ld. erről mások mellett Jacques Derrida: „Force of Law. The >>Mystical Foundation of Authority<<". Trans. by Mary Quaintance. Cardozo Law Review. vol. 11:919, 198990. p. 920-1046. A 927. oldalon írottak relevánsak itt: "To stay with the question of idiom, let me turn here to a German word that will soon be occupying much of our attention: Gewalt. In English, as in French, it is often translated as $>>$ violence $<$. The Benjamin text that I will be speaking to you about soon is entitled $>>$ Zur Kritik der Gewalt, $<<$ translated in French as $>>$ Critique de la violence $<<$ and in English as $>>$ Critique of Violence $\ll$. But these two translations, while not altogether injustes (and so not altogether violent), are very active interpretations that don't do justice to the fact that Gewalt also siginifies, for Germans, legitimate power, authority, public force. Gesetzgebende Gewalt is legislative power, geistliche Gewalt is the spiritual power of the church, Staatsgewalt the authority or power of the state. Gewalt, then, is both violence and legitimate power, justified authority.” Magyarul csak az elöadás-szöveg második fele jelent meg: ld. Jacques Derrida: „A törvény ereje: az >>autoritás misztikus alapja<<”, in Gulyás Gábor, Széplaky Gerda (szerk.): Az árnyék helye. Tanulmányok a hatalom, a morál és az eröszak kérdéseiröl, Kalligram, Pozsony, 2011, 227-261.o.
} 
ellenségeiröl kíván beszélni. A thatcheri terminológiában ök (mindenekelött a PIRA) az „eröszak emberei”.

„Nem létezik olyan, hogy politikai merénylet, politikai robbantás vagy politikai eröszak. Csak bünügyi merénylet, bünügyi robbantás és bünügyi erőszak létezik. Számunkra itt nincs helye kompromisszumnak. Nem lesz politikai státusz""21 - igy az elsőként 1979-ben miniszterelnökké választott Margaret Thatcher nem sokkal az, 1981-es éhségsztrájk bejelentését követöen a brit alsóházban.

Az idézett megnyilatkozás első fele nyilvánvaló politikai hazugság. (Álnaivitás volna feltételezni, hogy pusztán ,, helytelen fogalomhasználat”.) Létezik olyan, hogy politikai merénylet, létezik politikai robbantás, és mindenekelőtt létezik politikai erőszak. Ez utóbbira példa maga az idézett megnyilatkozás is. Az erőszak monopóliuma a modern jogállam alapvető, alkotmányban rögzített hatalmi bázisa. Az állam akkor kezeli bünügyként az eröszakot, ha az nem egy államilag elismert, alkotmányosan szentesitett, az állam hatásköre alatt álló és jogfenntartás céljából végrehajtott erőszakot, hanem egy államilag nem felhatalmazott egyén vagy csoport által önkényesen, saját természeti (törvénytelen, jogteremtö) céljaik elérése érdekében végrehajtott eröszakot jelent.

A felszines látszat ellenére tehát az eröszak, és nem a terrorizmus, az 1981-es éhségsztrájk során kiélezödö brit kormány-PIRA konfliktus kulcsfogalma. A prométheuszi szituációhoz hasonlóan szentesitett, fennálló és nem-szentesitett, felforgató eröszak konfliktusáról van szó. A fentebb idézett Thatcher-mondatok archív felvételröl hangzanak el a Hunger címü film ama korai jelenetében, amelyben elsöként látjuk az éppen letartóztatott Davey Gillen (fiktiv) IRA-tagot közeli felvételröl, a rabszállitó kocsiban - útban a belfasti Maze börtön felé. A film elbeszélés-technikája a szembenálló csoportokat jellemző gondolkodás- és viselkedésmódokat néhány egyénített karakter szótlan gesztusán, élethelyzetén keresztül

\footnotetext{
21 "There is no such thing as political murder, political bombing or political violence. There is only criminal murder, criminal bombing and criminal violence. We will not compromise on this. There will be no political status."
} 
ábrázolja. Helyettük, a „,kisember” helyett beszél a képtől így még inkább életszerütlenül elütö, viktoriánusan érzéketlen, hatalmaskodó Thatcher-hang. Viszonylagos szótlanságuk ellenére azonban ezek a „,kisember”-alakok nem pusztán az adott társadalmi csoportok (protestáns börtönörök, katolikus bebörtönzött IRA-tagok) típus-képviselöi. Ellenkezöleg: a szélsőségesen uniformizáló (börtön)körülményekkel szemben filmnyelvileg egyénitett gesztusaik révén az emberi lény elfojthatatlan individualitását példázzák inkább. Másrészt nincs bennük semmi rendkívüli, pusztán a helyzet rendkívüli, amelybe kerültek. Bobby Sands alakja a kivétel.

Formailag különösen nagy súlya van annak a ténynek, hogy a nézö a filmidö közel egyharmadának elteltével szembesül elsőként nyilt eröszak-megnyilvánulással. Eddig csak elözöleg kifejtett erőszak nyomait és jeleit láthattuk: a börtönör mossa szétvert bütykeit a csap alatt; a feltehetöleg kiadós veréssel üdvözölt új rab, a már emlitett Gillen vérzö fejjel teszi meg elsö sétáját zárkája felé a börtönfolyosón. Mintha a kamerának volna szégyenérzete. Az elsö, filmnyelvileg explicit, törvényesen kiszabott, feltehetöen törvénytelen módon elkövetett eröszak-megnyilvánulás Bobby Sands alakjára összpontosul. A börtönszemélyzet több tagja üti-veri, majd eröszakosan megmosdatja, megborotválja és haját vágja a minden erejével ellenszegülö Sands-nek. Azért kiemelkedö jelentöségü ez a mozzanat, mert Sands alakján keresztül (a film feltehetö szándékai szerint is) a jogfenntartó állam és az engedetlen egyén közötti konfliktus letisztult formáját nyeri el. A filmbeli Sandsalak a törvényesen szentesitett brutalitást egyáltalán nem krisztusi méltósággal fogadja be és alakitja át más minőséggé; a film nem is nagyon burkolt sejtetése szerint célt is téveszt ezért a Sands-alakot értelmezö ír katolikus-nacionalista fóáramlat, amikor, feltehetöleg a máig igen erös pogány-katolikus Sands-kultusz sugallatainak sokszor gondolkodás nélkül engedelmeskedve, a föhös alakját egy szüken értett vallási-felekezeti szempontból krisztusi 
alakként értelmezi ${ }^{22}$. Nem, a film elsöre szembetünö rétegében ez az alak a jellem feddhetetlen és szigorú következetességével, a gyözelem leghalványabb reménye nélkül lázad szüntelenül félig-meddig önjelölt Prométheuszként a törvényes eröszak és a jogfenntartó eröhatalom ellen. Halálra szánt, reflektálatlan, rögeszmés következetessége a filmbeli Sands alakját inkább a mitikus-tragikus, mintsem a vallási szféra felé közelíti. Ám ez is csak látszat. A film utolsó harmadában az addig csak lappangva jelenlevö mitoszkritikai mozzanatok visszafogott müvészi eszközök révén teljesednek ki.

Thatcher tökéletesen tisztában volt azzal a veszéllyel, mellyel a Bobby Sands vezette PIRA-fogvatartottak makacs elszántsága az állam törvényes berendezkedését fenyegette. Itt nincs helye kompromisszumnak - az állam helyesen fogalmaz Thatcher hangján keresztül. A kompromisszum vereséget jelentett volna. A filmidő harmadik harmadánál, az aranymetszés-jellegü beszélö-jelenetet, a film atmoszférájához képest szokatlanul sok elhangzott szót követöen újabb szótlan jelenet, börtönbeli közjáték következik: egy börtönör takaritja el a börtönfolyosóról a protestáló rabok cellaajtóinak alsó résein vezényszóra kiboritott vizeletet. A takaritó időnként kiválaszt egy-egy cellát, melybe, mintegy bosszúképpen, besöpri az addig a pontig felgyült fertőtlenitöszeres vizeletet a folyosóról. A beállítás azt sugallja, hogy a kamerához közeledö őr elött gyülö fertötlenitett vizelet nemsokára a nézöt önti majd el. Mintha az államilag felhatalmazott, mégis illegitim erőszaktevők bosszút állnának a kamerán, amiért az addigi szemérmességét félretéve, nyilltan, szégyentelenül megmutatta tetteiket. A vágás után felülnézetböl a börtönfolyosó fertőtlenitöszeres-vizeletes padlóját látjuk. Újra megszólal felvételröl Thatcher hangja:

\footnotetext{
${ }^{22}$ A film alaposan helyre is rakja ezt a képzetet, és ezt a színvonalasabb recenziók természetesen észre is veszik. Peter Bradshaw értő és értékelö recenziója a Guardian-ben: http://www.theguardian.com/film/2008/oct/31/hunger, talán még érdekesebb Jim O'Neill recenziója a christiananswers-ön: http://www.christiananswers.net/spotlight/movies/2009/hunger2008.html, vagy A. O. Scott írása a New York Times-ban: The High Cost of Dignity: Recalling the Troubles in Stark Detail: http://www.nytimes.com/2009/03/20/movies/20hung.html
} 
„,Szembesülve hitelt vesztett ügyük kudarcával az eröszak emberei nemrég úgy döntöttek, hogy megjátsszák utolsó lapjukat. Börtönükben maguk ellen fordítják az eröszakot, halálig tartó éhségsztrájk formájában. A leginkább alapvető emberi érzésre, a szánalomra próbálnak hatni, azzal a céllal, hogy feszültséget keltsenek, és felszitsák a keserüség és gyülölet szikráit. "23

Talán a magyar forditáson is érezhetö ennek a megnyilatkozásnak az a sajátos regisztere, amelyet valószinüleg a negatív pátosz minöségével jellemezhetnénk legtalálóbban. Nem véletlen, hogy az angol szövegben Thatcher csak az egyik kategóriát említi azok közül, melyekkel Arisztotelész a tragédia befogadójára tett hatást jellemzi, nevezetesen a szánalmat (pity), és nem szól a félelemröl (terror). A tragédia az első jelentös (müvészet)történeti maradványa annak a romboló kritikának, mellyel az önmaga erejére ébredö egyén a sors által uralt mitikus világrenddel szembefordult. Thatcher és az ebben az esetben általa képviselt állam abban érdekelt, hogy az emberi viszonyok sorsszerü rendjét (az aktuális jogrendet, államot) tartsa fenn. Ha ezt a rendet egy heroikus jellegü gesztus, „elöadás”, társadalmi-politikai performansz fenyegeti, a legrosszabb megoldás volna az állam részéröl (mintegy beismerés- és önfeladás-jelleggel) terrorról, félelemröl beszélni, föként olyan félelemröl, mely a háttérben maradva, kimondatlanul (hiszen a kimondás úgy is szolgálna, mint a mesebeli titkos szó, amely képes megtörni a varázst) magát a jogrendet is biztositja. Ez az államhatalom következetes paranoiája.

A legtöbb sztrájktól eltérően a halálig tartó éhségsztrájk nem értelmezhetö úgy, mint egy társadalmi csoport zsarolási akciója az állammal szemben. Még kevésbé érdemes ebben az esetben jogi értelemben vett bünözésröl beszélni, hiszen az áldozat és az elkövetö azonos,

\footnotetext{
23 "Faced now with the failure of their discredited cause, the men of violence have chosen in recent months to play what may well be their last card. They have turned their violence against themselves through the prison hunger strike to death. They seek to work on the most basic of human emotions, pity, as a means of creating tension and stoking the fires of bitterness and hatred."
} 
igy hát a büntetőjognak nemigen marad kit megbüntetni. Evidens, hogy nem tekinthetö általános sztrájknak. Formailag tekintve ez az éhségsztrájk, függetlenül annak közvetlen politikai eredményétől, tiszta manifesztuma az egyén döntésének az állam szentesített törvényes hatalmával szemben. Thatcher nem késlekedett, hogy ezt a manifesztumot is, az „,erőszak embereinek” többi megnyilvánulásához hasonlóan, eröszakként minösitse. Csalhatatlan hatalmi-politikai ösztönnel érezte meg, hogy ez a helyes terminus. Amennyiben az egyén és az állam közötti hatalmi viszonyokat vesszük számításba, a halálig tartó éhségsztrájk valóban erőszakos tett: azt a jogfenntartó erőszakot támadja meg, amely a jogállam végrehajtó és kényszeritő hatalmának rejtett alapjaként szolgál.

A modern, demokratikusnak nevezett jogrend ugyanis ,, arra törekszik, hogy olyan jogi célokat tüzzön ki minden olyan területen, ahol az egyének [dieser einzelnen Personen] céljait erőszakkal lehetne hatékonyan elérni, melyeket csak a jogi erőhatalom képes ily módon megvalósítani. [...] A maximából következik, hogy a jogrendet aláásó fenyegetés minden olyan eröhatalom [Gewalt], mely az egyének kezében van. Az a veszélye, hogy meghiúsul a jogi cél és a jogszerü végrehajtás? Nem, mert akkor a jog nem általában itélné el az eröszakot [Gewalt], hanem csak akkor, ha jogellenes célokra használják. Azt mondhatjuk, hogy a jogi célok rendszerét nem lehet fenntartani, ha bárhol elöfordul, hogy természeti célokat eröszakos eszközökkel érnek el. De ez még csak puszta dogma. Ám talán dogma volta ellen szól, ha tekintetbe vesszük azt a meghökkentö lehetöséget, hogy a jognak nem azért érdeke monopolizálni az eröszakot az egyénnel [Einzelperson] szemben, mert a jogi célokat akarja biztositani, hanem azért, mert magát a jogot akarja biztositani. Hogy az eröszak, amennyiben nem a mindenkori jog kezében van, nem az általa elérhető célok révén fenyegeti a jogot, hanem már pusztán azzal, hogy valahol a jogon kívül létezik. "24

\footnotetext{
${ }^{24}$ Walter Benjamin, ,Az erőszak kritikájáról”, 31-32. W.B.: G.S. II, 182-3.
} 
Amennyiben a puszta hatalmi viszonyokat elméletileg vesszük figyelembe, egyáltalán nem számít az, hogy Bobby Sands és kilenc társa igaz és jogos ügy miatt haltak meg, vagy sem. Mert nem az erkölcsi igazságosság, hanem az erö(szak) (Gewalt) hívta életre azt a hatalmat, mely büntetéssel sújtja őket és ügyüket. Sands a magányos sztrájk legelemibb formájával, a természeti élet felfüggesztésével száll szembe ezzel a hatalommal, és az egyén és állam közötti harc kimenetele felfüggesztett marad ebben az akcióban - egyebek mellett ezt a megfontolást is sugallják a film szótlan szenvedélytöl fütött záró képsorai. A harc kimenetelének felfüggesztése a Prométheusz-mitosszal analóg. Prométheusz „,fenséges bátorsággal kihívja a sorsot, váltakozó sikerrel harcol ellene, és a monda meghagyja Prométheusznak a reményt, hogy egyszer majd új jogot ad az embereknek"25.

A filmidö közepén, megtörve az addig föként szótlan gesztus-elemekböl épitkezö elbeszélésmódot, egy hosszú, vita-jellegü beszélö-jelenetet láthatunk. A vita résztvevői a halálra készülö Bobby Sands és egy Kilrea-böl származó belfasti katolikus pap. Miután letudták a kötelezö csevegést, Sands rátér a lényegre: bejelenti a papnak elhatározását az éhségsztrájk elindítására vonatkozóan, valamint elmagyarázza neki, hogy ez az alkalom abban fog különbözni a megelözőektöl, hogy a sztrájk tétje ezúttal nem a tárgyalásokon való jobb feltételek kiharcolása, hanem részéröl/részükröl: a halál, a brit kormány/az állam részéről pedig: a kapituláció (a politikai státusz újbóli biztositása a PIRA- és INLA ${ }^{26}$ foglyoknak). A beszélgetés rendkívül sok politikai, vallási, társadalmi és lélektani réteget érint; itt most csak néhány vonatkozásra térek ki. A pap a jóérzésü (és ezúttal: jó eszü) katolikus kispolgár minden arroganciájával és vehemenciájával próbálja védelmezni a puszta emberi létezés (a természeti élet) szentségének avittas dogmáját. Bobby Sands alakja egyedül itt tünik Krisztuséhoz hasonlónak: ahogyan a pap arrogáns leckéztetését hallgatja, a Nagy Inkvizitort hallgató, Dosztojevszkij/Ivan Karamazov képzeletében formálódott

\footnotetext{
${ }^{25}$ Idem, 49.

${ }^{26}$ Irish National Liberation Army.
} 
Krisztust idézi. Hallgatásában lehet a krisztusira emlékeztető irónia, de szavaiban már inkább a mitikus hérosz hübrisze és a tragikus hös (alapvetöen jóslat-paródia jellegü) iróniája hallatja hangját. A pap a lényeget érintően téved, mikor azzal vádolja Sands-et, hogy mártírszerepre tör. Sands pedig a szituáció lényegére tapint rá, mikor úgy fogalmaz, hogy puszta hite a maga egyszerüségében (értsd: puszta formájában) a legerösebb és leghatalmasabb dolog. Sands önmagára kényszeritett alakjának prototípusa nem a mártír, hanem Prométheusz, mely prototípus a legszélsöségesebben idealista (és, ahogy Benjamin egy töredéke is sugallja: kapitalista) filozófiai formáját Nietzsche Übermenschében nyeri el. A film harmadik harmada tanúsitja, hogy a film készitői végül kritikusan engedetlennek mutatkoznak a mitikus hérosz képzetével szemben, amelyet addig mintha, bár fenntartásokkal, de felkarolni látszottak volna. Ahogyan a fájdalmasan lassan haldokló és gyengülő emberi lény hanyatló testét, romló érzéki benyomásait és hallucinációit bemutatják, a természeti lény bukottságának szomorúsága lép a csodálat tárgyaként kinálkozó mitikus heroizmus helyébe. A halál közelségében egy kétségbeejtően szeretetre és törödésre méltó emberi teremtményt látunk: a félelemre és csodálatra számot tartó mitikuskultikus hös helyett.

$* * *$

Az éhségsztrájkról szóló hosszú kitérőből visszatérve vegyük fel újra Az erőszak kritikájáról szóló írás érvelésének a fonalát. A sztrájkjog után a hadijogra tér át Benjamin elemzése. A jognak az erőszak kisajátítására támasztott igénye, valamint az erőszak jogteremtő jellege érvelése szerint a háborús erőhatalomra és a hadijogra vezethető vissza. A hadijog a jog ősformájának bizonyul érvelése szerint. A békekötés szankcionálási kényszere az új jog bevezetését és felhatalmazását jelenti. 
„A $>>$ béke $<<$ szó abban a jelentésében, amelyik a $>>$ háború $<<$ ellentettje (van tudniillik egy egészen más, hasonlóképpen nem-metaforikus és politikai jelentése is, ezt használja Kant, amikor az >>örök békéröl<< beszél), egyenesen a mindenkori győzelemnek erre az ilyen a priori és minden egyéb jogviszonytól függetlenül szükséges szankcionálására vonatkozik. E szankcionálás abban áll, hogy az új viszonyokat új $>>$ jognak $<<$ ismerik el, teljesen függetlenül attól, hogy de facto szükség van-e valamilyen biztosítékra a további fennállásukhoz. Ha tehát a háborús erőhatalomból mint a dolog őstípusából [nach der kriegerischen Gewalt als einer ursprünglicher und urbildlicher Gewalt] következtetést lehet levonni minden természeti cél érdekében alkalmazott erőszakra nézve, akkor minden ilyen erőszaknak jogteremtő jellege van.” (Walter Benjamin, i.m., 35; G.S., 185-6).

\section{$* * *$}

Immanuel Kant tiszteletére és a sorsfogalom további tisztázásának érdekében ide is beszúrok egy terjedelmesebb kitérőt. Az örök békéről (1795-96) szóló filozófiai tervezet első toldalékában, az örök béke garanciájáról szóló gondolatmenet során kerül elö első izben a sorsfogalom, mégpedig a természet és a Gondviselés közötti (tulajdonképpen az ész számára elégtelennek bizonyuló, egy „ismeretlen ok kényszerének” mutatkozó) meghatározásként. Nem a sors, hanem a természet/Gondviselés szolgál az örök béke garanciájául: „Ami e biztosítékkal (garanciával) szolgál, nem csekélyebb valami, mint a nagy müvész, a természet maga (natura daedala rerum), melynek mechanizmusából szemmel láthatóan kiviláglik a célszerüség, az, hogy az emberek meghasonlása által akár önnön akaratuk 
ellenére is egyetértést szándékszik teremteni köztük, amiért is, minthogy egy müködése törvényeit illetöen elöttünk ismeretlen ok kényszerének mutatkozik, sorsnak mondjuk, ám mérlegre téve a világ folyásában megnyilatkozó célszerüségét, mely mintha valami, az emberi nem objektív végcélját megszabó és a világ e folyását elöre kijelölő ok mély bölcsességéröl vallana, Gondviselésnek hivjuk, noha e Gondviselést a természet müvészi berendezéséböl [Kunstanstalten] meg nem ismerhetjük voltaképp, még csak nem is következtethetünk rá belöle, csak (mint a dolgok formájának célokkal való kapcsolatát illetően általában is) hozzágondolnunk lehet és kell, hogy az emberi müalkotások analógiájára lehetöségéröl fogalmat alkossunk magunknak, s ha elképzeljük egybekapcsolódását és összehangzását a tiszta ész által számunkra közvetlenül kitüzött (erkölcsi) céllal, akkor oly eszmére leltünk, amely elméleti tekintetben ugyan szertelen, gyakorlati tekintetben ellenben dogmatikus, valóságát [Realität] illetően pedig szilárdan megalapozott (mint példának okáért az örök béke szabta kötelesség fogalma tekintetében, hogy érdekében fölhasználjuk a természet emlitett mechanizmusát). "27 Ebben a dolgozatban, Kant elképzelésétöl némiképp eltérően és inkább egy újra elgondolásra és megfogalmazásra szánt emberi, semmint isteni, gondviselöi aspektusból kiindulva, a természethez hozzágondolt, elöfeltételezett instancia dialektikus jellegü, és ennek megfelelöen egy fogalompárral: a szabadsággal és a bünnel (avagy a szabadság árnyékával) jellemezhető. Kantnak a következö, Az örök békéröl függelékében szereplö kijelentése, melynek során másodjára szerepel a sors fogalma, helyesen kezeli a fogalom kétértelmüségét, viszont a töle megszokott túlságos bizalommal viseltetik az ész világos és egyértelmü erkölcsi útmutatásának követhetö voltában. Az erkölcsnek valóban tilos meghátrálni a sors/hatalom elött; ám a saját erőit illetően is érdemes őt mértéktartásra inteni, mert az erkölcs ereje, még ha teljesen az idea/filozófia/bölcsesség által

\footnotetext{
${ }^{27}$ Immanuel Kant: „Az örök békéről. Filozófiai tervezet (1795-96).” Ford. Mesterházi Miklós. In uő: Történetfilozófiai írások. Ictus, 1995-97. 278-80.
} 
meghatározott is, még mindig túlságosan is emberi. A következö szövegrésznek tehát inkább az elsö felével, mintsem a másodikkal tudok teljes mértékben azonosulni (külön figyelemreméltó, ahogyan Kant a mítosz nyelvét használja): „, Az erkölcs határnok-istene nem hátrál meg Jupiter (a hatalom határnok-istene) elött; mert emez a sors kezében van még, vagyis az ész nem elég megvilágosult ahhoz, hogy áttekinthetné a meghatározó okok sorát, melyek a természet mechanizmusa alapján elöre bizonyossággal megjelentenünk engednék az emberi cselekedetek és mulasztások sikerét vagy balsikerét (bár kedvük szerint hagynak a sikerben reménykedni minket). Ám hogy mit is kell tennünk, ha (a bölcsesség szabályainak engedelmeskedve) a kötelesség szabta pályán szeretnénk maradni, arra az ész mindenütt épp elég világosan rámutat, s ezzel világosan rámutat a végcélra is." (Kant: $i$. m., 289-90.) A kézirat-töredékekben szereplö mondat tovább árnyalja ezt a képet, és világosan megmutatja Kant kérlelhetetlen polgári ellenállását a sors/hatalom mechanizmusaival (itt: a ,gyakorlat” embereivel) szemben, de azt is, hogy a háborúról (és analogikusan a bünröl) alkotott elképzelése némiképp mégis megmarad a természeti szférán (a szükségszerüségen) belül (a vegetatív létmódra utaló metaforika árulkodik erröl): „,Mert hogy a háború a nyers emberi természetbe (a kultúra kedvéért) ideiglenesen beleplántáltatott, nem bizonyitja még, hogy mint a végcéltól elválaszthatatlan eszközt megfellebbezhetetlen végzés rótta volna rá, és hogy így volna, az a gyakorlat embereinek cselfogása pusztán, mellyel csupán mechanikus állam-és jogismeretüket iparkodnak leplezni és megszépiteni.” (Kant: i. m., 290-91.)

$* * *$

Emlékeztetőül újra idézem a Kant-kitérő előtti Benjamin-szövegrész záró mondatát: „Ha tehát a háborús erőhatalomból mint a dolog őstípusából következtetést lehet levonni minden 
természeti cél érdekében alkalmazott erőszakra nézve, akkor minden ilyen erőszaknak jogteremtő [rechtsetzend] jellege van.”

Az erősebb szava a „törvény” (jog) - ez idáig felületes közhelyszámba menő felismerés; a szankcionálás elengedhetetlenségének belátása viszont megnyithatja a kritikai perspektívát. A béke-szankció révén életbe lépő új jogi viszonyok a győztesre és a legyőzöttre egyaránt érvényesek lesznek. Walter Benjamin gondolatmenetének alakulását ezen a ponton nyilvánvalóan befolyásolhatta a versailles-i békeszerződések friss élménye; a wilsoni etnikai-területi-népszavazási elvek érvényesülésének többé-kevésbé teljes kudarca, a győztesek „,igaza”. Ezekben a békeszerződésekben, talán kézzelfoghatóbban, mint valaha korábban, manifesztálódott a (béke)szerződés és a jogteremtés erőszakos eredete: az egyenlőség elvének szinte már a látszatára sem ügyeltek a békecsinálók. A következmények katasztrofális volta „győztesekre” és „,vesztesekre” egyaránt: ma már nyilvánvaló. A jogteremtés erőszakos eredete teszi azonban még a szociális-gazdasági vagy etnikai egyenlőtlenségek iránt leginkább érzékeny jogegyenlőséget is démoni módon kétértelművé. Ahogyan a természetből sem „nő ki” erőszak, úgy formális jogegyenlőségből még soha, semmilyen módon nem „nőtt ki” magától a szociális egyenlőségre való törekvés, és nem is fog soha, hiszen ez utóbbi sokkal inkább politikai és társadalmi akarat függvénye, mint az előbbi. Persze előbbi nélkül viszont gyakorlatilag bajos elképzelni az utóbbi törekvés lehetőségét; mindenesetre annyi világosnak tünik a szankcionálás nélkülözhetetlenségének belátása felől, hogy önmagában a jog természeténél fogva nem ismer (szociális) egyenlőséget, csak egyenlő nagyságú, megengedett, felhatalmazott vagy tiltott erőszakot.

A jogteremtő erőszak mitikus, gyakran heroikus jellegü. Ezt példázzák többek között az európai forradalmak történetében az elengedhetetlen hősök és hőskultuszok, vagy az 
államalapításhoz (még legújabb kori eseteihez is) kötődő mítoszok. A sors [Schicksal] az, ami „minden esetben alapjául szolgál a jogi erőhatalomnak”. „A jogteremtésben [Rechtsetzung] ugyanis kettős funkciója van az erőszaknak, mégpedig abban az értelemben, hogy a jogteremtés az erőszak eszközével éri el a célját, azt, amit mint jogot megteremt, de nem mond le az erőszakról, miután elérte a célt, megteremtette a jogot, hanem éppen akkor teszi csak a szó szoros értelmében, méghozzá közvetlenül, jogteremtővé, ugyanis nem valami erőszakmentes és erőszaktól független, hanem azzal szükségképpen és belsőleg összefüggő célt tesz meg - hatalom néven - jognak. Jogot teremteni annyi, mint hatalmat teremteni... [Rechtsetzung ist Machtsetzung...]" (50, G.S. 197-8)

A mitikus, archaikusan sorsszerü társadalmi rendekben a kijelölt határok íratlan törvények voltak. Részben ezt jelöli a tabu fogalma. Vegyük egészen komolyan azonban íratlan természetüket: valójában, még képlékenyen szimbolikus jellegük révén, hatalmuk éppen meghatározatlanságukban rejlett, és abban, hogy a megfoghatatlan elöírásokat gyanútlanul megszegőkre, a mitikus/tragikus bünt elkövetőkre (a naiv lázadókra, hogy Rousseau idézett gondolatmenetének egy alternatíváját kínáljuk fel) a szintén meghatározhatatlan és felderíthetetlen eredetű sors ereje mérte rá a bünhődést. A meghatározatlanság kulcsmozzanat. Az antik társadalmak politikai küzdelme az írott jogért maga is átfogó lázadásként értelmezhető a sorsszerü rendek, vagyis a meghatározatlan eredetű erőszak- és hatalom-megnyilvánulások korlátlan uralma ellen. A másik átfogó lázadás, az előbbitől természetesen korántsem függetlenül, a müvészet területén mehetett végbe: elsőként a tragédia, majd a komédia és a mese révén. Az írott jog rendszereiben azonban mind a mai napig (óhatatlanul!) megőrződött az az elemi meghatározatlanság, mely íratlan elötörténeti formáiban, a történeti távlat, valamint az attikai tragédia megformálása révén, világosabban felismerhető. Jól mutatja közvetetten ezt a („,megszüntetve”) megőrzött alapelemet többek 
között a jogi kazuisztika és a XIX. századtól kezdődően elburjánzó ,jogidegen” (pszichiátriai, szociológiai stb.) ítéletmodulációk története. Mindez onnan fakad, hogy a sorsot előrajzoló bủn fogalma ugyancsak két szférára, a természetire (pszichológiaira) és a szellemire (etikaira) lett (valóban és újra csak démonikusnak mondható módon) vonatkoztatva. A két szféra elválasztását kísérlik meg például az olyan jellegü modern, már a közbeszéd elemeinek tekinthető jogi-pszichológiai-pszichiátriai terminuspárok, mint: beszámítható/beszámíthatatlan, elöre megfontolt (aljas) szándék/hirtelen felindulás stb. Franz Kafka müveiben, különösképpen $A$ perben és $A$ kastélyban sürítve, mintegy az időt, a történelmet felgöngyölítve jelentkezik az íratlan és írott jog rejtett kapcsolatának ez a sajátossága. „Itt megvan ugyan az írott jog a törvénykönyvekben, de csak rejtve, és e törvényekre támaszkodva az előidők [die Vorwelt] még korlátlanabbul gyakorolják hatalmukat.” - írja szintén Walter Benjamin Kafka írásai kapcsán ${ }^{28}$. Az a már jegyzetben említett modern alapelv is az íratlan jogi hatások megőrzéséről tanúskodik, hogy a törvény nem ismerése nem menti föl az elkövetőt a büntetés alól. Ami biztosítja a folytonosságot az íratlan és az írott jog között, az mindenekelőtt a bün fogalmának a (potenciálisan végtelen) képlékenysége. A bünfogalom képlékenysége a bün meghatározhatatlanságából (,,eredendő” voltából) adódik. A bünfogalom eredendő meghatározhatatlansága, képlékenysége megnyitja az utat a fogalom teljes feloldódása, mindenre alkalmazhatósága előtt. Ambivalens, vallási és jogi (szellemi és „természeti”) jellege, hegeli értelemben vett „rossz végtelensége" pedig potenciálisan végtelen számú és nagyságú (hatalmi) visszaélésre ad alkalmat. Az európai történelemben talán a XV., XVI. és XVII. században elterjedő boszorkányüldözések kínálják az első ijesztően kiterjedt és határokon átívelő példát ennek a folyamatnak a kibontakozására. Rátelepedve a lokális konfliktusok közösségen belüli tradicionális rendezésére a bárhol felfedezhető bün ekkor, a XV-XVII. századi Európában

\footnotetext{
${ }^{28}$ Walter Benjamin: „Franz Kafka. Halálának tizedik évfordulójára.” Ford. Tandori Dezső. In Walter Benjamin: i.m. 781-817. (787). (első megjelenés: 1934). G.S. 422.
} 
válik elsőként mindenre alkalmazható csodafegyverré a hatalom és a jog közvetítése révén a vádlók kezében. Gustav Henningsen a XVII. század eleji baszkföldi boszorkányhisztériát tárgyaló könyvének epilógusában ezzel a problémával kapcsolatban arra hívja fel a figyelmet, hogy meg kell különböztetni egymástól az archaikus népi hiedelem-együttesként felfogható boszorkányságot és a járványos boszorkányhisztériát. „A két jelenség rokonságban áll, de az a közkeletű vélemény, miszerint az utóbbi csak az előbbinek a felfokozott változata, a dolgok elfogadhatatlan leegyszerüsítése.” A boszorkányhisztéria éppen az értelmiségi-hatalmi elem miatt válhat kiterjedt járvánnyá. „A kollektív boszorkányhisztériát úgy határozhatjuk meg, mint az üldözési ösztönkésztetés kirobbanó formáját, melyet a népi hiedelmek és a bizonyos értelmiségiek által a boszorkányságról kidolgozott eszmék időleges találkozása, egybeesése vált ki. A konkrét európai esetben azt mondhatjuk, hogy a falusi népességben élö, annak sajátját képező boszorkányhiedelmek és a teológusok által a boszorkányságról kifejtett, intellektuális síkon mozgó elméletek elegyedése volt az, ami az emberek ezreinek elméjét megzavarta. A demonológia, a teológusok és jogászok tudós okoskodásainak, vitáinak és vizsgálódásainak e terméke és tárgya, mindaddig ártalmatlan volt, amíg az értelmiségi szférán belül maradt; nyomban kártékonnyá lett azonban, mihelyt a prédikátorok a szószékröl és a bírók a törvényszéken megpróbálták az elvont fogalmakat a napi életben előadódó konkrét esetekre alkalmazni és viszont. Az ilyen típusú helyzetek kedveztek a kollektív mentális változásoknak, új boszorkányságmintákat hozva létre, melyek villámgyorsan termelődtek ki, s termékük, a boszorkányhisztéria, egy csapásra magával ragadta mind a köznépet, mind a müvelt elitet." ${ }^{29}$ A boszorkányság mitológiája és démonológiája nem népi-archaikus elem, hanem intellektuális konstrukció, mely többek között lehetővé tette az üldöztetések járványos

\footnotetext{
${ }^{29}$ Gustav Henningsen: A boszorkányok ügyvédje. A baszk boszorkányság és a spanyol inkvizició (1609-1614). Ford. Szuhay-Havas Ervin. Kossuth, 1988. 280-281.
} 
elterjedését is a vád és a „bün” csodálatos képlékenységének segítségével. A sorsfogalom kritikáját a bủnfogalom vonatkozó kritikájával kell majd időről időre kiegészítenünk.

Míg a természeti célokra alkalmazott mitikus erőszaknak (a hatalom megalapozásának) jogteremtő (rechtsetzend) ${ }^{30}$ funkciója van, addig a már fennálló jogi viszonyok között, kifejezetten jogi célokra alkalmazott erőszaknak (amelyre az államot immár jogszerủen fennálló erőszak-monopóliuma hatalmazza fel) jogfenntartó (rechtserhaltend) funkciója van. A jogfenntartó funkció hadijogot érintő példája (miként a jogteremtőé a békekötés szankcionálása volt) a militarizmust lehetővé tevő általános hadkötelezettség. Ezért mondhatja Benjamin, hogy minden jog a „sorsszerüen megkoronázott erőszakból [schicksalhaft gekrönte Gewalt]"31 ered. Minden felszíni ellentmondás ellenére a természetjog és a pozitív jog erőszak-elvei kiegészítik egymást. ${ }^{32}$

Az antik, mitikus sors-elképzelés (vagy még inkább: sors-érzet) a történeti torzulások, és a felügyelet hatalmi-ellenőrző technológiáinak modern, ugrásszerü fejlődése következtében egyre inkább látens módon uralkodik a modern jogrendben és büntetés-végrehajtásban. Ez az uralom, mivel megnyilvánulásai nem olyan szembetünők, nem nyíltan rituális jellegủek, mint az íratlan törvények feltehető idején, körmönfontsága, egyre inkább személytelenedő jellege, rutin- és hálózatszerűvé válása, valamint látens mindenütt-jelenvalósága révén valójában még hatékonyabb, még inkább érvényes az írott jog, azon belül is a pozitív jog által kiegészített természetjogi elveken alapuló modern, demokratikusnak nevezett államok

\footnotetext{
${ }^{30}$ Walter Benjamin e terminusa kizárólag ebben az írásában szerepel.

${ }^{31}$ G.S. 188.

32 A büntetés ősi jogával kapcsolatban hasonló megkülönböztetéseket eszközöl, és hasonló következtetésekre jut Bibó István Etika és büntetőjog címü 1938-as dolgozatában. Miután elválasztja egymástól a természetjog apriorisztikus és a pozitivista jog a posteriori büntetésfogalmát, a tanulmány a következő feladatot tüzi ki: „A következőkben azt az utat fogjuk keresni, mely a büntetés értelméről szóló klasszikus vitakérdés teljes felszámolása felé vezet. A két szembeállított tétel mindegyikéböl ki kell emelnünk azt a lényeges momentumot, mely rávilágít a büntetés funkciójára, s rá fogunk jönni, hogy e momentumok nem ellentétesek egymással." Bibó István: „Etika és büntetőjog”, in uő: Válogatott tanulmányok, I. kötet, Magvető, 1986, 172.
} 
társadalmaiban. Ez többek között a kafkai életmü egyik legfontosabb civilizációtörténeti tanulsága. Ez annál inkább igaz, hogy maga a pozitív jog is régóta kritika tárgya a modern jogelméleten és még a modern joggyakorláson belül is.

Az íratlan jognak ez az anakronisztikus uralma ugyanis Benjamin érvelése szerint nem ellentétes a felvilágosodás etikai (kanti) programjával, a kategorikus imperatívusz látszólagos kérlelhetetlenségével. „Mert a pozitív jog, amennyiben tisztában van gyökereivel, nagyon is megköveteli, hogy minden egyén személyében elismerjék és előmozdítsák az emberiség érdekét. A pozitív jog ezt az érdeket valami sorsszerü rendnek ${ }^{33}$ a kialakításában és fenntartásában látja [in der Darstellung und Erhaltung einer schicksalhaften Ordnung]” (37, G.S. II. 185, kiem. tőlem). A sors-funkciót a jogfenntartó erőhatalom intézményei és gyakorlatai (és Foucault szellemében hozzátehetjük: ezek kirajzásai az úgynevezett magánszféra, civil közszféra és a „szabad” piaci-üzleti versenyszféra területeire) biztosítják: a jogfenntartó erőhatalom „úgy bizonyul fenyegetőnek, mint ahogy a sors, hiszen a sorstól függ, hogy utoléri-e a bünözőt [der Verbrecher verfällt]" (Az erőszak kritikájáról, 38, G.S. 2, 188). És a modern felügyelet, mint az antik sors, szándéka és célkitüzése szerint potenciálisan mindenütt jelen van, és mindenen uralkodik. De aktuálisan nem minden esetben válik, válhat ez nyilvánvalóvá. Itt marad tehát, és kell is maradnia valamilyen meghatározatlanságnak, amely biztosítja a fenyegetést. Többek között a fenyegetés meghatározatlanságának a felfüggesztése miatt

\footnotetext{
${ }^{33}$ Idekívánkozik egy újabb szövegrész Az örök békéről szóló filozófiai tervezet függelékéböl, mely talán a modern bürokratikus attitüd egyik első érvényes és általános leírása: ,a moralizáló politikusok [ellenben] azzal, hogy jogsértő államelveiket szépítgetik, arra hivatkozván ürügyként, hogy az emberi természet alkalmatlan az ész elöirta eszmét követve a jóra, amennyire rajtuk áll, a javulást lehetetlenné, a jogsérelmet pedig örökössé teszik. Ezek az államügyekben kiokosult férfiak a praxis helyett, melyre oly rátartiak, praktikákkal élnek, hisz csak az jár a fejükben, mint vethetnék martalékul a népet, $s$ ha kell, az egész világot az épp uralkodó hatalomnak, csak hogy annak szája íze szerint szólhassanak (nehogy önnön javukat kockára tegyék); ahogy azt a vérbeli jogászok is szokták (a mesteremberek, nem a törvényhozók), ha felkapaszkodtak a politikáig. S mert nem az a dolguk, hogy a törvényalkotással bajlódjanak, hanem hogy az ország törvényeinek épp előadódott parancsolatait végrehajtsák, számukra bármiféle épp hatályos törvényes alkotmány a legjobb alkotmány is egyben, $\mathrm{s}$ ha azon felsőbb helyről változtatnak, akkor ez újabb a legjobb; s benne minden, úgy, ahogy van, a maga illő mechanikus rendje szerint van.” (Kant: i. m., 294-95.) Egyszerü képletként összefoglalva: egy társadalomban minél több az esztelen, reflektálatlan végrehajtás, annál kevesebb a szabadság. A(z ön)kritikátlan köz-szolgálat észrevétlenül elvtelen hatalom-szolgálattá válik.
} 
szokták a totalitárius rezsimeket „illegitimnek”, vagyis jogtalannak, „rablóállamnak” nevezni. Továbbá, bár ennek a fejezetnek ez nem szorosabban veendő feladata, alapos pszichológiai elemzéssel (Søren Kierkegaard ebben az irányban elvégzett kutatásait, főként A szorongás fogalmát, valamint $A$ halálos betegséget alapul véve) kimutatható volna, hogy minden jogi erőhatalom, eseti intézkedések során jórészt tudattalanul, önnön eredetéről megfeledkezve, de a legbiztosabb bázisként a halálfélelem egyetemességére apellál: az egyetlen kikezdhetetlen bizonyosságtól való félelemre, melynek bekövetkezési ideje másrészről a legbizonytalanabb; innen a félelmetes fenyegetéshez szükséges meghatározatlanság. A halálfélelem lappangó jelenlétére való apellálás még a legártalmatlanabb törvényi szabályozásban is jelen van. Ez az átható összefüggés részben megmagyarázza azt az egyébként egyáltalán nem magától értetődő tényt, hogy az állampolgárok túlnyomó többsége, legyen bármilyen államnak polgára, ösztönösen jogkövető magatartást tanúsít. Amennyiben és ameddig állampolgár. Mindenféle jogi gyakorlatban, még az angolszász precedensjogban is kardinális kérdés ezért a jog hatékonyságára nézve a halálbüntetés és a pallosjog: az apriorisztikus, proto-természetjogi büntetéselv alappillérei. „A halálbüntetés az, amelyik a leginkább kihívta maga ellen a kritikát, amióta a pozitív jog érvénye kétségessé vált. A halálbüntetés mellett szóló érvek a legtöbb esetben nem voltak lényegbevágóak, de a mögöttük rejlö indítékok mindig elvi jelentőségüek, és azok is maradnak. A kritikusok érezték - bár talán nem tudták volna megindokolni, sőt valószínűleg érezni sem akarták -, hogy a halálbüntetés elleni támadás nem egy büntetőjogi tételt, nem törvényeket, hanem magának a jognak az eredetét [das Recht selbst in seinem Ursprung] kezdi ki. Ha ugyanis a jog az erőszakból, a sorsszerủen megkoronázott erőszakból ered, akkor nem nehéz megsejteni, hogy a legfőbb, az élet és halál fölötti erőhatalomban [Gewalt], ott, ahol az megjelenik a jogrendben, a jog eredete ütközik ki reprezentatív módon a már fennálló viszonyokon, és termékeny módon 
megnyilvánul [manifestieren] bennük. [...] De a halálbüntetésnek valójában nem az az értelme, hogy megtoroljon valami jogsértést, hanem az, hogy új jogot statuáljon. Mert az élet és halál fölötti hatalom [Gewalt] gyakorlásával sokkal inkább megerősítést ad magának a jog, mint más büntetések végrehajtásával. De ebben egyúttal valami avíttság nyilvánul meg a jogban, különösen a finomabb érzület számára, mert az végtelenül távolinak érzi magától azokat a viszonyokat, melyek között az ilyen büntetés végrehajtása a sors sajátos fenségéről tanúskodott.” (38. G.S. 2, 185.)

Az választja el tehát a halálbüntetést az összes többi büntetéstől, hogy az lényege szerint nem eszköz, hanem elsősorban megnyilvánulás. Ilyen értelemben, történjék titokban akár, mindig lényegi marad benne a rituális, mitikus, reprezentáló elem. Nem pusztán egyik jogfenntartó eszköze a szankcionált jogi erőhatalomnak, hanem magának ennek a hatalomnak, pontosabban e hatalom eredetének a manifesztuma és megerősítése. A természeti élet feletti korlátlan uralom, a végzet értelmében értett sors (Ananké), és ezen keresztül közvetve a jogi ítélkezés korlátlan uralmának látszatlehetősége nyilvánul meg benne. Rousseau az élet és halál joga kapcsán már idézett gondolatai kifejtése után nem sokkal ösztönös, ám felemás érvényü politikai érzékkel megjegyzi - jóllehet nem érvel e megjegyzés mellett -, hogy csak meggyengült jogi erőhatalom büntet sürün halállal: „A halálos ítélet gyakorisága mindig a kormányzat gyengeségének a jele”. (Rousseau, i.m., 47.) Ez részben igaz lehet a megreformált, demokratikus közhatalom nevében fellépő büntetésvégrehajtás esetében, ám a monarchikus-reprezentáló hatalom számára nyíltan, és nem látens módon létkérdés a halálbüntetés, akárcsak a pallosjog. Persze ez nem jelenti a monarchia jog- és hatalomgyakorlása számára sem azt, hogy a halálos ítéletek gyakoriságát feltétlenül fokoznia kell. A „klasszikus korban”, különösen a „felvilágosult abszolutizmus” büntetés-végrehajtásában a kínhalál végtelenül felaprózott fájdalom-színháza látja el a 
megingathatatlannak vélt hatalmi aszimmetriát kifejező hatalmi-operátori funkciót. A háborús jog és a büntetés ősi joga a királyság kínhalál-rituáléjában nyíltabban mutatja fel közös eredetét, mint a modernebb képviseleti közhatalom büntetés-végrehajtásában. „A büntetés joga tehát a jog egyik olyan oldala lesz, amelyet az uralkodó magának tart fenn, hogy háborúzzék ellenségeivel: a büntetés >>a pallosjogból ered, az élet és halál fölötti abszolút hatalomból, amelyről a római jogban merum imperium néven tesznek említést $<<34$. Ez azt is jelenti, folytatja Foucault, hogy a ,jogtudósok” állításával szemben a kínhalál elsődleges funkciója nem ,preventív”, nem példastatuáló, hanem reprezentálóterrorisztikus jellegü volt. A politikai funkció fontosabb volt benne, mint az igazságszolgáltatási: utóbbinak csak az előbbi adott életet. „A büntető szertartás tehát teljes egészében $>>$ terrorizáló $<<$ [...] A kínhalál gyakorlatát $[\ldots]$ nem a példa statuálása tartotta fenn abban az értelemben, amit annak idején az ideológusok adtak neki (szerintük a büntetés bemutatása semlegesíti a büntettet), hanem a rémület politikája: az uralkodó fékezhetetlen jelenlétét mindenki számára érzékelhetővé kell tenni a bünös testén. A kínhalál nem az igazságosságot állította vissza, hanem a hatalmat mozgósította újra.” ${ }^{\circledR 3}$ A jog és az erő(szak) funkciói leplezetlenül válnak eggyé, pontosabban szét sem válnak a király „fegyveres igazságszolgáltatásában”. „Ez az aprólékos szertartásrend nyíltan nemcsak törvényszéki, hanem katonai jellegű is. A király igazságszolgáltatása fegyveres igazságszolgáltatásnak mutatkozik. A bünöst büntető kard egyben az a kard, amely elpusztítja az ellenséget." ${ }^{36}$ A „klasszikus kor” abszolút monarchiájában valójában nem összemosódik, hanem még el sem válik világosan egymástól az elítélt bünös és a legyőzendő vagy elpusztítandó ellenség képzete.

\footnotetext{
${ }^{34}$ Michel Foucault, i.m., 65-66. Foucault a következő szövegből idéz itt: P. F. Muyart de Vouglans: Les Lois criminelles en France, 1780. XXXIV.

${ }^{35}$ Foucault, i.m., 67.

${ }^{36}$ Foucault, i.m., 68.
} 
Az újabb kori történelem felkínál egy példát, amikor egy önmaga közhatalmi jogfenntartó eszközeiben végzetesen nem bízó és részben éppen ezért a végletekig militarizált politikai erőhatalom, a német harmadik birodalom az élet és halál fölötti korlátlan uralmat akarta egyszerre látens, ám totális módon egy egész, ráadásul szétszórt és amorf közösség felett módszeresen és technológiailag is megalapozva kinyilvánítani a zsidóság megsemmisítésére tett kísérletben. 


\section{Ananké}

„Ki a Jognak $\mathrm{s}$ az isteneknek adósa, jaj annak: a sorsa halálos, a sorsa halálos!"

Euripidész: Hekabé (Horváth István Károly ford.)

„másokkal van tele valamennyi temető”

Mihail Bahtyin: A szerző és a hős

(Patkós Éva ford.)

A büntetés-végrehajtás modern intézménye, a börtön, totális hospitalizáló jellegének megfelelően, és mint a jogilag meghatározott „szabadságtól” való megfosztás, minden szándékolt intézkedésével, valamint akarattalan, mechanikus hatásaival is a sors és az „emberfeletti” mitikus erők érvényesülésének rabszolgája. A nemzetiszocialista megsemmisítő-táborok gyakorlata arra irányul, hogy maga ez az érvényesülés is totális legyen, ezért azt is gondolhatnánk, hogy ezek a táborok mind a mai napig a modern büntetés-végrehajtás eszményi megvalósulását jelentik. Le kell azonban határozottan szögezni, hogy a megsemmisítés ilyen egyértelmüen kitüzött és kimunkált célja a nemzetiszocialista táborokon kívül példa nélküli a büntetés-végrehajtás történetében. 
Kegyetlenül hangzik, de: az eredménytől (a megsemmisítettek számától) függetlenül. Ez a jó szándékú kegyetlenség ${ }^{37}$ veszi el az élét azoknak a „történelmi jelentőségről” folytatott „vitáknak”, melyekben hatékony érvként szerepelhet az a tény, hogy például az egyébként hosszabb ideig müködő szovjet munkatáborokban többen haltak meg, mint a nemzetiszocialista megsemmisítő-táborokban, hogy az ottomán török népirtás (melynek áldozatai örmények, asszírok, anatóliai görögök, zsidók voltak) a nemzetiszocialistákat megelőzve legalább olyan kegyetlenséggel elkövetett, etnikai gyülölködés által vezérelt népirtás volt, mint amilyent a KZ-táborok produkálni tudtak, vagy hogy a koncentrációs tábor intézményét valójában a brit gyarmatosító imperializmus találta fel. A megsemmisítőtáborok megkülönböztető jegye nem a tényleges hatékonyság, sem a gyülölködési motiváció természetrajza, sem nem a kegyetlenség. Nem ezek avatják a Soa névvel illetett folyamatot történelemfilozófiai szempontból a legmeghatározóbb eseménnyé Jézus keresztre feszítése óta, ahogy Kertész Imre szokott fogalmazni esszéiben, kissé Pilinszky János gondolkodását idézve meg. Hogy mi avathatja azzá mégis, arra néhány távoli utalást tettem az előző alfejezet végén. Ezt a kitüntetett történelemfilozófiai jelentőséget azonban nem szabad, vagy legalábbis nem igazán célravezető egy jól fazonírozott lineáris oksági magyarázat kereteire redukálni. Ahogy a történelmi eredők, úgy az eredmények és következmények is szerteágazóak. Fogalomkritikai szempontból: a bűnfogalom teljes feloldódása, és ennek révén az etikai szférát maradéktalanul hatalmába kerítő, így azt végső soron meg is semmisítő jogi-hatalmi ítélkezés eredményezte azt, hogy a büntetésvégrehajtás szélsőséges gyakorlata tetszőlegesen bárkire alkalmazhatóvá vált. ${ }^{38}$ A huszadik

\footnotetext{
${ }^{37}$ Erre a ,jó szándékú kegyetlenségre” apelláló elbeszélői attitűdre jó példa Kádár Gábor és Vági Zoltán nagyszerü könyve, A végső döntés. Berlin, Budapest, Birkenau 1944 (Budapest: Jaffa, 2013).

${ }^{38}$ Jean Améry $A$ kínvallatás című vallomásos esszéjének kitérőjében a nemzetiszocializmus megkülönböztető jegyét, ,esszenciáját”, személyes, a belgiumi breendonki erődben szerzett tapasztalataira alapozva, de azoktól elmondása szerint mégiscsak függetlenül, a kínzásban találja meg. Én nem találok ilyen egyetlen terminussal lefedhető esszenciát. A nemzetiszocialista rendszer történelmi unikalitását tekintve osztom Améry véleményét, érvelését és indoklását azonban nem mindenben tudom követni, még ha tanúságtétele és a tapasztalás átruházhatatlan egyediségének érzékletes közvetítése tiszteletre és értelmezésének elfogadására kötelez is vele szemben. Ami számára a személyes, egyedi tapasztalás valósága, az számomra a történelmi tapasztalás valósága,
} 
század, és főként annak első fele, tudjuk jól, a kitelepítésekkel, népirtásokkal és

tömeggyilkosságokkal járó etnikai tisztogatások évszázada is. Az azonban nemcsak ebben

az évszázadban, hanem a történelemben is egyedülálló, ahogy a német nemzetiszocialisták

és európai kollaboránsaik egy teljes nép kiirtását tüzték ki célul; és ezt nem pusztán hatalmi

hőzöngésnek (annak is), utópikus vágyálomnak (ha tudattalanul, de annak is), hanem

technológiailag megvalósítandó programnak tekintették. A kérdést érintő megszólalásokban

megszokott, időnként félrevezető és hamiskás, önmaga fenségességében gyönyörködő

pátosztól jórészt mentesen, prózai józanságra törekedve foglalja össze magyar szempontból

talán elsőként az ehhez a jelentőséghez hozzájáruló tények egy részét Bibó István

Zsidókérdés Magyarországon 1944 után címü 1948-ban megjelent írásában: „1944. március

19-én azonban megkezdődött Magyarország német megszállása, s háromnapi habozás után

a kormányzó a Sztójay-kormány kinevezésével beadta a derekát. A megszállók hamarosan

elhatározták a magyar zsidóság deportálását és kiirtását. A megszállók után nemsokára

megjelent a megkülönböztető jel viselését elrendelő rendelet, ezt követte a zsidók gettóba

tömörítése. A deportálást a németek a nyilas irányítás alatt álló magyar közrendészeti

hatóságok, főleg a csendőrség segítségével hajtották végre. Ez gyakorlatilag úgy történt,

és ezért leírásom jóval közvetettebb, és nyilvánvalóan kevésbé érzékletes. Egyébként végső soron ott mégis rokonítható a gondolatmenetünk, hogy a kínzás is egyik megjelenési formája a természeti élet, a „test” feletti korlátlan jogi-hatalmi uralomnak, amely korlátlan és gátlástalan uralom eszméjét kétségkívül a

nemzetiszocialista rendszer közelítette meg leginkább. Jean Améry tanúságtételében a fájdalom lesz ennek fő kritériuma. „Akit ugyanis kínzás közben legyürt a fájdalom, az úgy tapasztalja meg a testét, mint soha annak előtte. Húsa totális valósággá válik az önmegtagadás során. Olyan életmomentum a kínzás, amely enyhített formában már a segítségre váró betegek számára is részben jelenvalóvá és tudatossá válik, és a mondásban, hogy addig vagyunk jól, amíg nem érezzük, hogy van testünk, valóban vitathatatlan igazság fogalmazódik meg. De csak a kínvallatás során lesz teljes az ember hússá válása: a fájdalmában ordító, az erőszak alatt összeroskadó, segítségre nem számító, önvédelemre képtelen megkínzott csupáncsak test már, és semmi más. [...] Nagy a kísértés, hogy továbbfüzzük ezt a gondolatot. Azt mondottuk, a fájdalom testi mivoltunknak az elképzelhető legnagyobb felfokozása. De úgy gondoljuk, talán ennél is több: maga a halál. A halálhoz nem vezet bennünket logikai út, de legyen szabad azt gondolni, hogy a fájdalom érzelmi utat alakít ki bennünk hozzá. A végén ehhez az egyenlethez jutunk: test = fájdalom = halál, ez pedig a mi esetünkben arra a feltevésre redukálható, hogy a kínvallatás, aminek során a másik által testté leszünk, eltörli a halál kontradikcióját, és lehetővé teszi, hogy megtapasztaljuk önnön halálunkat. Csak a személyes tapasztalatot hozhatjuk föl rá mentségül, és magyarázatképp hozzá kell füznünk, hogy a kínvallatás a kitörölhetetlenség vonásával rendelkezik. Akit megkínoztak, megkínzott marad. Kitörölhetetlenül beleégetődött a kínzás, akkor is, ha nem marad klinikailag kimutatható nyoma. A kínvallatás örök emléke jogosítja fel a megkínzottat a spekulatív elrugaszkodásokra, melyek nem feltétlenül magasra ívelök, de mégis számot tarthatnak némi érvényességre.” Jean Améry: „A kínvallatás”. In uö: Túl bünön és bünhödésen. Esszék. Ford. Blaschtik Éva. Budapest: Múlt és Jövö, 2002. 55-56. 
hogy a deportálás módját és menetrendjét a németek szabták meg, a zsidók összeszedését és vagonba rakását a csendőrök végezték igen kegyetlenül, a szerelvényeket a németek vették át s vitték ki; a magyar hadsereg és a magyar közigazgatás pedig, kedvtelenül vagy szívesen, embertelenül vagy emberségesen, elvégezte azokat a másodrendű feladatokat, amelyeket a deportálás felvetett: táborok felállítását, élelmezését, iratok kiadását és felülvizsgálatát, mentesítések elbírálását, szerelvények irányítását stb. Már maga az összeszedés, az eldugott értékekre irányuló esetleges vallatás, a vagonba rakás és az elszállítás a legtöbb helyen borzalmas feltételek között történt, amibe terhes asszonyok, szülő nők, betegek, gyermekek és öregek [például a kilencvenéves Löw Immánuel szegedi főrabbi - L. Z.] sokasága pusztult bele s fizikailag erős emberek sokasága őrült meg. A deportáltak túlnyomó része német megsemmisítő táborokba került, az emberi méltóság semmibevevésének olyan körülményei közé, melynek párját a történelem, az ókori és keleti rabszolgaság és a gladiátorjátékok számbavételével sem ismerte eddig: az embereknek korra és nemre való tekintet nélkül, kopaszon és meztelenül való kiválogatása után, szinte elképzelhetetlen élelmezési és tisztasági viszonyok közepette, gázkamrákon, kőbányákon, agyonzsúfolt barakkokon, napokig tartó gyalogmeneteken, tábori bordélyházakon és embereken kísérletező orvosi laboratóriumokon keresztül irányították őket az ott szokásos halálnemek, a gázhalál, a tűzhalál, a tarkólövés, az agyonveretés, az agyonkínzatás, az agyondolgoztatás, az éhhalál, a fagyhalál és az orvosi kísérletek áldozataiként való elpusztulás felé. Az egész megnagyobbodott Magyarországról összeszedett deportáltak száma körülbelül hétszázezer körül volt; ezeknek túlnyomó része német megsemmisítő táborokban pusztult el; vagy százezer-egynéhány azok közül, akik mindezt túlélték, vagy szelídebb táborokba, mezőgazdasági munkára kerültek, tért vissza, a többi Németországban s onnan egyéb külföldre szóródott szét." 39

\footnotetext{
${ }^{39}$ Bibó István: „Zsidókérdés Magyarországon 1944 után”. In Bibó István: Válogatott tanulmányok. Corvina, 2004. 230. o.
} 
Bibó ekkor, 1948-ban, nyilván a megfelelő történeti források híján is, még igen megengedően is fogalmaz a magyar fél felelősségéről akkor, amikor a deportálásra és kiirtásra vonatkozó döntést egyértelműen a „megszállóknak” tulajdonítja. Kádár Gábor és Vági Zoltán könyve, A végső döntés. Berlin, Budapest, Birkenau 1944 a döntés közös felelősségére hoz fel érveket és bizonyítékokat. „A holokauszt során soha annyi embert nem deportáltak olyan rövid idő alatt, mint 1944 tavaszán Magyarországról. Ahogy látni fogjuk, a magyar zsidók deportálására egy többlépcsős, evolutív német-magyar döntéssorozat eredményeként került sor." ${ }^{40}$ A magyarországi holokauszt fő döntéshozói és kivitelezői német részről Adolf Eichmann, magyar részről pedig a belügyminisztériumi államtitkári rangjánál aránytalanul nagyobb (véleményformáló) tekintéllyel és hatáskörrel rendelkező Endre László. „,[1944 április 22-én] Az Endre család szentkúti birtokán teljes körü, kétoldalú megállapodás született a magyarországi német biztonsági szervek és a belügyminisztérium vezetésének csúcstalálkozóján. [...] A résztvevők Endre és Eichmann párhuzamos erőfeszítéseinek hatására elfogadták az elképzelést, hogy az összes magyar zsidót Auschwitz-Birkenauba deportálják. Erről, az immár konszenzuális és végső döntésről, április 23-án hajnali fél 2-kor Veesenmayer [budapesti német nagykövet] értesítette Berlint. [...] A következő 9-10 hétben a radikális zsidótlanítási politikának nem volt valódi alternatívája. A szentkúti végső döntéssel kapcsolatban széles körü konszenzus alakult ki. A zsidók elhurcolását egyaránt támogatta Berlin és Budapest, a végrehajtásba lelkesen kapcsolódtak be a magyar és német hivatalok. Miközben országszerte gőzerővel folytatódott a gettósítás, május közepén beindult a holokauszt legnagyobb deportálási akciója, amely még Auschwitz-Birkenau történetében is példátlan méretü tömeggyilkosságba torkollott."41 A lezárásban pedig a többször megjelenő kíméletlen, megvilágító erejü szarkazmussal állapítja meg a következőket a szerzőpáros: „A magyar

\footnotetext{
${ }^{40}$ Kádár Gábor - Vági Zoltán: A végső döntés. Berlin, Budapest,Birkenau 1944. Budapest, Jaffa Kiadó, 2013. 146.

${ }^{41}$ Idem, 147-8.
} 
holokausztra a német megszállás nélkül minden valószínűség szerint nem került volna sor. De arra talán még a legoptimistább gyilkosok sem számítottak, hogy az invázió utáni tizenkettedik napon (március 31.) már döntés születik az általános gettósításról, további tizenhárom nap (április 13.) elég lesz ahhoz, hogy a teljes magyar politikai vezetés, kormányzóstul, miniszterelnököstül hozzájáruljon 100 ezer állampolgára deportálásához, és csupán újabb kilenc napnak (április 22.) kell eltelnie addig, hogy a magyar királyi belügyminisztérium teljes vezetése kedélyes, vidéki környezetben vacsorázgatva, lelkesen mondjon igent a holokauszt történetének legátfogóbb deportálási akciójára, amely a leghatalmasabb náci megsemmisítőtábor, Auschwitz-Birkenau fennállásának legvéresebb mészárlásához vezetett." 42

Könyvükben a szerzők alapos forráskritikai elemzéssel és hathatós érveléssel vezetik elő az általuk találóan (bár talán kissé megengedő eufemizmussal) „elfeledett hagyománynak” nevezett ellentörténelmi tablót a Kárpát-medencében a középkortól kezdődően válságos történelmi szituációkban újra és újra kibontakozó etnikai tisztogatások, kitelepítési tervek, spontán pogromok sorának számbavételével. Az érvelésük nem azt a leegyszerüsítő és történetietlen elképzelést támogatja, hogy a pogromoktól egyenes vonalú egyenletes mozgás vezetne az Auschwitz-Birkenauba induló vonatokig, hanem inkább világosan rámutat arra, hogy amennyiben a zsidóirtási koncepció magja nem ilyen jól előkészített talajba hullik bele, annyiban szárba szökkenése sem lehetett volna ilyen példátlanul gyors.

Hasonlóképp, ha megengedhetetlen túlzás is azt mondani, hogy a modern büntetésvégrehajtás intézményeinek világosan artikulált, operacionális célja megegyezne a megsemmisítő-táborok céljával, akkor azt mindenesetre már kockázat nélkül kijelenthetjük, hogy a modern, izoláló/hospitalizáló büntetés-végrehajtás mélyén munkáló titkolt, még inkább elfojtott eszményt (a „tiltott vágyat”) legesleginkább a megsemmisítő-táborok

\footnotetext{
${ }^{42}$ Kádár-Vági, i.m., 255-6.
} 
gyakorlata közelítette meg, akár tetszik ez a kortárs, demokratikusnak nevezett jogállam feltétlen híveinek, akár nem.

A következőkben azt a szépirodalmi művet igyekszem kritikailag értelmezni, mely az imént felvillanó történelmi katasztrófa-konstellációnak alapvető fontosságú, s mind a mai napig jórészt rejtetten munkáló következményeire, egyáltalán, fő történelemfilozófiai problémakomplexumára képes a maga sajátos forma-tartalom egységével érvényesen utalni. Ez Kertész Imre Sorstalanság címü könyve.

A Sorstalanság címü könyv főszereplőjének, Köves Gyurinak felgyorsított fegyencszocializációja (az idő gazdasági szempontból felfogott szerepét is tekintve) a fegyencszocializációk eszménye. Minden életjelenségen eluralkodik a sorsszerű rend, az ősigék közül pedig, legvégül totális értelemben, Ananké uralkodik. Mindez a cselekmény szerint természetesen nem egy csapásra történik, hanem körmönfont lassúsággal: a „normálisnak” mondható polgári viszonyok közül egymást át- és elfedő események során, elliptikusan és ironikusan felépülő emlékező elbeszélésen keresztül kerül a főszereplő a megsemmisülés határára - és azután vissza az immár kísértetiesen „normálisnak” mutatkozó polgári viszonyok közé.

A sors-mechanizmus beindulását és hatékony működését nem pusztán a szükségszerünek mutatkozó esetlegességek (mint például a második fejezetben az első csók a légoltalmi pincében), a szinte nyíltan ironikus-szatirikus jellegű megjegyzések (például a sárga csillaggal kapcsolatosak az első fejezetben), hanem azok a szókratészi iróniát (az elhallgatást) kiélező, a platóni anamnézist és mítosz-paródiát idéző jóslatszerü képek is nagyban elősegítik, melyek mintegy „félre”-szerüen törik meg az aszketikus és eszköztelen 
elbeszélő prózanyelvet (mely utóbbit pedig a könyv elörehaladtával egyre inkább ellenpontozza a leíró próza képi gazdagsága). Az első fejezet elején, miután az iskolából apja kérésére elengedték, a főszereplő máris alvilági látogatást tesz egy mellékutcában, az éppen munkaszolgálatra készülődő apja „tulajdonában” lévő fapincébe, ahova „meredek lépcső visz le a homályba”. Lenn az üzletet éppen átvenni készülő, és egyébként főként a mostohaanya jelenlétében gyanúsan zavartan viselkedő Sütő úr (akinek „faji tekintetben [...] teljesen rendben a szénája”) mint egy alvilági jelenés tünik fel hirtelen a mély sötétségbe (a felnőttek világába) ekképpen alászálló, éppen felpillantó Köves Gyuri szemébe (még Sütő úr elnagyolt arcleírása is a középkori és barokk színjátszás intrikushivatalnok-ördög figuráját villantja fel egy sejtelemszerü képben). „Egy pillanatra a szemem is lehunytam, mert kissé még káprázott az odafönti napsütéstől. Azalatt apám mondott valamit, mire kinyitottam, Sütő úr. Barnás színezetü, kerek arcán - a keskeny bajuszkával meg a kis hézaggal az elülső két, széles, fehér foga közt - mindenütt sárgásvörös napkorongok ugráltak, mint fölfakadó kelések.” (Sorstalanság, 7-8.) Bár feltételezhetjük, hogy az elbeszélés idejében alakot öltő Köves Gyuri is találkozott már fölfakadó keléssel, mégis erős a gyanú, hogy a hasonlat utótagja az emlékező Köves Gyuri tapasztalásából adódik, és az ő „közbeszólásának”, „félré”-jének tekinthető. A könyv figyelmes újraolvasásakor, a vég ismeretében pedig határozottan ironikus jóslatjellege lesz a képnek. ${ }^{43}$ A tartaroszi világ többször is hírt ad magáról az expozíció során; még az első

\footnotetext{
${ }^{43}$ Vegyük észre, hogy ez nem egészen ugyanaz az ironikus müködés, mint amelyet Molnár Sára (egyébként alapvetően joggal) állapít meg a könyv nyelvi müködése kapcsán: „A Sorstalanságban a nyelv munkája teremt ironikus-komikus hatásokat: egyrészt a szituációhoz nem illö hangnem [itt azért felmerül az emberben, hogy milyen „hangnem” illene vajon? Van valamilyen, akár tagadásokkal körülírható hangnem, ami egy szituációhoz bizonnyal illik? - L.Z.] (az olvasó érzékeli, hogy a fiú által megtanult és használt szavak nincsenek összhangban azzal, ami történik [ugyanúgy: milyen szavak volnának „összhangban” azzal, ami történik? stb. - L.Z.]), másrészt pedig a színházban működő drámai irónia hatásfunkciója is nyomon követhető, mikor a közönség (ez esetben az olvasó) többet tud, mint a színjátékban résztvevők (ez esetben a regényhős), és a végkimenetelt is sejti. [...] Sőt, a regény nyelve is többet tud, mint maga a hős, aki azt használja, tökéletlenül.” Molnár Sára: „Az emlékezés bolondsága. Sorstalanság” In uő: Ugyanegy téma variációi. Irónia és megszólitás Kertész Imre prózájában. Kolozsvár: Koinónia, 2005, 42-3. Az utolsóként idézett mondat valamelyest pontosít az összképen, de érzésem szerint még mindig redukálja a könyv nyelvi rétegzettségét; erről majd később próbálok bővebben szólni a föszövegben. Ehelyütt legyen elég annyi, hogy a fentebb említett „ironikus jóslatjelleg” semmiképpen sem az olvasó „regényhőssel” szembeni többlettudásában képződik, hanem az olvasás lineáris folyamata során
} 
fejezetben a családi vacsoratársaságból hallgatásával és egyszerü, szeretetteljes gesztusaival kiváló nagyapát nyeli el a családi-felnőtt alvilág homálya (,egyszer se hallottam megszólalni, de ahányszor arrafelé esett a pillantásom, mindig ott láttam, ugyanabban a sarokban, ami lassanként elhomályosult...”, 23. o.); Gyuri érzékelése számára maga a családi vacsora kifejlete is ebbe a homályba burkolózik, melyben képtelen eligazodni („Már csak egy-egy arc vagy mozzanat összefüggéstelen töredéke jutott el hozzám, mintegy kiválva a köröttem levő ködböl...”, 31. o.); vagy ilyen, a nyiladozó nemiséget érintő alvilági híradás a futólag már említett első csók ,,a légoltalmi óvóhelyen, pontosabban az onnan nyíló egyik elhagyatott, félhomályos pincejáratban” (42.). Ez utóbbi esemény egy másik, lényeget érintő szempontból is igen jelentős, ugyanis ezzel kapcsolatban bontakozik ki első ízben a sorsképzet logikai-spekulatív tematizálása is: a csók másik résztvevője, Annamária, ahogy ez a romantikától közvetlenebbül-naivabban és tisztábban érintett leánykamaszkorban igen megszokott, hamar, egy nap alatt eljut a véletlennel való indoklástól a végzetszerünek a felismeréséig. (42.o.: „, - A bomba volt az oka az egésznek így vélte.” 43-4.o.: „, - Úgy látszik, így kellett történnie. - Különös, már-már szigorú kifejezése volt az arcának, s nem is vitattam nézetét, habár inkább értettem egyet azzal, amit tegnap mondott, hogy a bomba volt az oka. De persze semmit se tudhatok, s úgy láttam, őneki így jobban tetszett.” Az eleve agnosztikus/sztoikus hajlamú Gyuri itt még, ingadozva bár, de az esetlegesség magyarázata felé hajlik, azonban „érzelmi okokból” a szükségszerünek enged). Az expozíció lezárásában, a második fejezet végén aztán már nem a puszta tematizálás szintjén, hanem a filozófiai problémafelvetés méltóságával mutatkozik meg a sorsképzet Gyuri és a nagyobbik nővér kvázi-platóni dialógusában. Az első fejezetben még csupán ironikus megjegyzések alkalmának mutatkozó sárga csillag itt az

rajta-benne is működik; csak a „vége” felöl nézve lesz racionalizálható, de akkor már magától értetődően a szereplö-elbeszélő számára is. Egyébként is általában az a derengő benyomásom, hogy a Sorstalanság legtöbb értelmezője tendenciózusan naivabbnak érzékeli a „regényhőst”, azaz a szereplő-aspektust (és ezzel együtt nem különbözteti meg kellöképpen az emlékezö-elbeszélö-aspektustól, pontosabban nem érzékeli a két aspektus folytonos egymásba játszását), mint amilyen az talán valójában. 
egész szituációt uralja baljós „fényével”. Hogy a sárga csillagot viselő ember bensejében ugyanúgy, ahogy a koldus vagy a királyfi ruhájában, nincs valami lényegileg más, ez a nagyobbik nővér számára, aki a fiatalok közül a legfogékonyabbnak mutatkozik a sorsképzet súlyosságával, a „bün” mélybe húzó erejével kapcsolatban, joggal elviselhetetlen gondolat. A még ártatlanul szabad Gyuri számára pedig joggal evidens. De mivel mélyebb megismerést érint, kimondása a felszínen (az elbeszélés technikájában, szerkezetében) úgy tételeződik, mint az eredendő bün, mely a sors-mechanizmust aztán a harmadik fejezettől visszafordíthatatlanul pályára állítja. Ez az expozíció technikai funkciója. Az elbeszélés idejében alakot öltő Gyurit ennek megfelelően a maga kettős értelmével érinti meg a bűntudat és a szabadság sejtelme: ,Zavarban voltam, mert hisz én voltam a hibás, de hát nem tudhattam, hogy ez a gondolat ennyire fontos lehet néki. Már szinte a számon volt, hogy így szóljak: ne törődjön vele, hisz az én szememben mit sem jelent mindez, én nem vetem meg a fajtájáért; de mindjárt éreztem, ezt azért kissé nevetséges volna mondanom, s

ezért aztán nem is mondtam. Csakhogy mégis, bántott, hogy nem mondhattam, mert abban a pillanatban valóban ezt éreztem, egész függetlenül helyzetemtől, hogy azt ne mondjam: szabadon.” (48-9.) A büntudat (a bün) azonban, és vele együtt a sorsképzet a történelmi konstellációval összhangban felülkerekedik: „most először történt velem, hogy olyasmit éreztem, ami azt hiszem, csakugyan, egy kissé a szégyenkezéshez hasonlított.” (49.)

$$
* * *
$$

A középkori és barokk szomorújátékból meritö (proto-)romantikus végzetdráma (föként a calderóni) kapcsán ír Walter Benjamin a sajátos, pogány-katolikus sorsképzet szerepéről: „A végzet [Schicksal] ugyanis nem természeti történés, éppoly kevéssé, mint ahogy nem is 
tisztán történelmi. [...] Elemi természeti erö [Naturgewalt] a históriai történésbe ágyazva, mely teljes egészében nem természet, mivel még felfedezhető a teremtés állapotán a Kegyelem Napjának visszfénye. De az ádámi bünbeesés [Verschuldung] pocsolyájában tükrözödik. [...] A sors gondolatának lényege inkább az a meggyöződés, hogy a bün [Schuld], mely ebben az összefüggésben mindig a teremtmény lényegéhez tapadó bünt [kreatürliche Schuld] - keresztény értelemben: az eredendö bünt [die Erbsünde] -, nem pedig a cselekvő személy erkölcsi mulasztását jelenti, bármily futólagos megnyilatkozás révén is, kiváltja az okozatiságot, a feltarthatatlanul lejátszódó, végzetes események [Fatalitäten] eszközét. A sors [Schicksal] a történés entelekheiája a bün [Schuld] területén.”

Mind az elbeszélö-emlékezö, mind az elbeszélés eseményidejében alakot öltő Köves Gyuri leggyakrabban használt határozószava a „természetesen”. Ezt a „,természetet” így, mitikusan, helyenként a mitikus értelemre reflektáló iróniával, majd, a lezárás során egy kitüntetett helyen, a legmélyebb humorral átitatva érdemes érteni. (Ld. többek között: Sorstalanság, 147, 233.)

A kitérö elején idézett szöveghely közelében ír Walter Benjamin a szertelen esetlegesség szerepéröl a cselekményszövésben: „Ha valaki ezt gondolná: >>Amikor valószínütlen véletlenekkel, kiagyalt helyzetekkel, túlságosan bonyolult intrikákkal... találkozunk, vége... a sorsszerüség benyomásának $<<$, alapvetöen tévedne. Mert éppen azok a távoli kombinációk, melyekről minden elmondható, csak az nem, hogy természetesek, éppen azok felelnek meg a különböző sorsoknak a történés különbözö területein. [...] Werner teológiai célzata nem pótolhatta olyan pogány-katolikus konvenció hiányát, mely Calderónnál az élet apró bonyodalmaival egy asztrális vagy mágikus végzet [Schicksal] hatékonyságának bizonyítására szolgál. "44

\footnotetext{
${ }^{44}$ Walter Benjamin: „A német szomorújáték eredete.” 322-3. GS 1, 306-7.
} 
A Sorstalanság elbeszélésmódjának tendenciózussága jóval visszafogottabb, de azért nem véletlen, hogy az elbeszélö a sors-mechanizmust (és a deportálást) megállithatatlan pályára állitó harmadik fejezet elején többször is az események szokatlanságára hívja fel a figyelmet, elsőként méghozzá a fejezet nyitómondatában: „Másnap egy kissé furcsa esetem volt.” (Sorstalanság, 51.) Valamint: „Általában az ö véleményük is az volt, amit magam is körülbelül hasonlóan láttam, hogy egészében véve az ügy kissé szokatlan, de hát bizonyára tévedés vagy valami efféle lehet.” (55.) Utóbbi közlésben a gyanútlanság is fontos elem.

A harmadik fejezet felütése indítja be a megállíthatatlannak mutatkozó sorsmechanizmust. Ahogyan Goethe Orfikus ösigék címü versciklusában, Erósz itt sem mutatkozik erösebbnek Ananké hatalmánál (és csakúgy, mint ott, csak Elpisz képes túlmutatni majd rajta). A családtól, az épp csak kibontakozni készülő „,szerelemtől”, a „magánélet” vonatkozásaitól a „közélet”, a „politika”, az állam (a magyar, majd a német) démonikusnak mutatkozó képviselői egyre növekvő igénnyel veszik át az életszervezés feletti hatalmat. A familiáris vonatkozások elkerülhetetlen felbomlása miatt ötlik fel a fejezet lezáró mondatában a szereplő Köves Gyuri képzeletében a „futó gondolat” mostohaanyja arcáról, ,amikor ráeszmél majd, hogy ma este már bizony hiába számít rám a vacsorával." (73.)

Sokat mondó ellenpontozással a közvetlen miliö leírása e váltás kezdetekor már nem idézi az alvilági homályt és ködöt (hiszen a jóslat-funkció, miként a tragédia cselekményének napvilágánál is, megkezdte beteljesülését; jóllehet a távolban, mintegy a horizont figyelmeztetéseként, ott állnak a gyárkémények): minden szikár napfényben áll; sőt a kamasz fiúk „véletlenszerüen” összegyült, mindennapi rutinjukból hirtelen-váratlan 
kiszakadt csoportja még egy sajátos bukolikus idillt is megidéz egy pillanatra. A tragikus hős a döntés fényében áll; ezúttal a fény vakítja el azokat, akik döntésre képtelenül sodródnak az események, a történelem úgynevezett áramával. A vámháznál posztoló rendőr alakja „tudatlanságánál” fogva rokon a fiúkéval: benne még pusztán a felelősségtől való menekülés szinte ,ártatlannak” tetsző démoni elve érvényesül. A bünösen ártatlan sodródás a készülődő történelmi vihar sorsterében: ez az a magatehetetlen magatartás, amelyet a korabeli úgynevezett ${ }^{45}$ többségi társadalom nagy részéről visszatekintve valóban csak a legnagyobb jóindulattal feltételezhetünk. „,>>Rozi<<, miután néhány fiú már biztatta, meg is tudakolta a rendőrtől: nem lesz-e baj, ha elkésünk a munkából, s hogy tulajdonképp mikor szándékszik minket tovább, a dolgunkra bocsátani. A rendőr cseppet se haragudott a kérdésért, de hát azt felelte, ez nem rajta, nem az ő elhatározásán múlik. Mint kitünt, valójában ő se tudott sokkal többet minálunk: bizonyos $>>$ további parancsot $<<$ említett, ami majd helyébe lép a régebbinek, melynek az értelmében addig egyelőre neki is, nekünk is várakoznunk kell - nagyjából így magyarázta el.” (55.) Szeretnék emlékeztetni Kant gondolatára az úgynevezett gyakorlat embereiről: reflektálatlan, ,ártatlan” parancsvégrehajtásukkal bármilyen hatályos törvény sorsmechanizmusát esztelenül indítják be ők. A vég ismeretében persze könnyü ítélkeznünk az effajta ,ártatlanság” felett; és az etika kérlelhetetlensége előtt a rendőrnek, pontosabban a rendőr egyenruhájában lévő ember etikai mulasztásának valóban nem lehetne mentsége; tekintve azonban, hogy lényegében költött figuráról van szó, akire képtelenség etikai ítéletet alkalmazni (még ha olyasfajta költött alak is ő, akinek a szokásosnál erősebb történelmi referencia-igénye van), a

\footnotetext{
${ }^{45}$ Ügynevezett, mert a „„öbbségi” jelző azt a lehetőséget foglalja magában, mintha a korabeli Magyarországon élt zsidók és cigányok nem lettek volna magyarok. Még ami a korlátozott jogkörü állampolgárságukat illeti, úgy is azok voltak, állampolgárságuktól sem a Sztójay-kormány, sem a nyilasok nem fosztották meg őket. Persze a kérdés nem egyszerü, és a „mi a magyar?” egész túlterhelt kérdéskörét maga után vonja, amelyre ebben az írásban nem térhetek ki. Egy regénybeli csendör-alak visszataszító elszólásán keresztül a Sorstalanság is reagál lakonikusan, a maga fekete humorával a problémakörre. Másrészt természetesen a könyv egyik ki nem mondott alapfeltevése szerint a korabeli magyarországi és (legalábbis a közép- és kelet-)európai társadalom egészéről (beleértve a zsidóságot is), néhány egyéni kivételtől eltekintve, elmondható, hogy asszisztált. Ez volt a normális; a kivétel, az ellenállás, a „makacsság” pedig a nem-normális, az őrültség. Itt megint Tadeusz Borowski (kő)világával érintkezik a Sorstalanság világa.
} 
könyvben megjelenő, erőszak-szervezeteket képviselő alakokhoz hasonlóan alakját nem morálisan megítélnünk, hanem a cselekmény szövetéböl kiszálazva megértenünk kell. Ebben az értelemben érvényes és szemléletes a rendőri attitűd hasonlósága a kereskedőkéhez, akik „,miután maguk közt előzőleg a nehéz időkről meg a lanyha üzletmenetekről tanakodtak”, végül is már csak a ,gondterhelt kedvetlenséget”, valamint „mintegy a dolgok változtathatatlan rendeltetésébe” való „kényszerü belenyugvást” érzik. (Sorstalanság, 68.)

A vámházba érkező felnőttek leírása során a szellemi meghatározások felől átmenetek révén halad az elbeszélő az érzelmi-animális jellemzőkig; a felnőttek mintegy a sorssal szembeni attitüdök típusskáláját mutatják be már az elbeszélésnek ezen a szakaszán is: míg az „Utas” a hallgatásba burkolózó, ám valójában idejében cselekvésre kész szellem kiváró türelmét, a „Szakértő” a szervilis tudálékosság terméketlen kötekedését példázza, addig a leginkább beszélő nevü „Balszerencsés” ember a sorsmechanizmuson való spekuláció végeláthatatlan labirintusába menthetetlenül elvesző „kafkai” típust hozza, akinek „,ezer apró, kérdő ráncba” rendeződő homloka „szomorú, csapdába esett rágcsálóhoz hasonlított kissé” (64.); az eleve „fókaarcú” emberként megnevezett figura pedig az „utas” szimmetrikus ellenpontjaként nem a szabályszegés bátorságát, hanem a jellemtelenségre való apellálást „választja”, így az ő „furcsa mozdulatára” vonatkoztatott kép idézi meg legnyíltabban az animális-alvilági régiókat (beszéde pedig alighanem öntudatlan hasbeszélés): ,azután végül is csak kívülről matatott, futkosott és kaparászott egy ideig a melle táján a keze, ritkás szőrzetü nagy pók, vagy még inkább amolyan kisebb tengeri szörny módján, mely mintegy a rést kereste, hogy a kabátja alá iramodjon. Ö maga ezalatt még mindig beszélt, és az a bizonyos mosoly is egyre ott volt még az arcán.” (66.) A 
könyvben egyébként az állatokat megjelenítő, jórészt metonimikus képek tendenciózusan a szellem hiányára utalnak mindenütt.

A mitikus vonatkozások a városban való menetelés során aztán újult és egyre inkább megsokszorozódó erővel támadnak fel. Ahogy a nap szép tiszta nyári délutánra fordul, a város átláthatatlan labirintussá válik, melyből a kivezető utat csak az „Utas” „hosszú szökkenése”, cselekvésének meglepő egyszerüsége - szabadsága találja meg (70-71.). Az alvilág kapuja ezúttal „szürke épületek útvesztőjére”, majd egy kaszárnyaudvarra vezet - az erőszak-szervezetek képviselőinek démonikussága pedig a rendőri ál-tudatlanság felelőtlenségétől a csendőri anakronisztikus-reprezentáló, hatalmaskodó felelőtlenségig süllyed (72-3.).

A csendőri attitüdben (negyedik fejezet) már nyíltan (és a német SS-tiszteknél ügyetlenebbül, bumfordibban, kevésbé elegánsan és ezekkel összefüggésben kevésbé hatékonyan) munkál az Ananké-igény. Mintha egy ügyefogyott és kisstílü sorsügynök beszélne: „Senki se higgye - figyelmeztettek a vizsgálat délelőttjén a csendőrök -, hogy elrejtheti elölük a bűnét, a pénzt vagy az arany- és értékneműeket.” (79.) A „Szakértő” morálisan vak, üres intellektualizmusa be is dől ennek a felszíni különbségnek: „Még a [német] tiszt $>>$ modoráról $<<$ is külön szót ejtett: ellentétben a csendőrök >>otrombaságával $<<$, azt >>józannak, mérsékeltnek és minden tekintetben kifogástalannak<<írta le. Egy másik kérdésre válaszolva ismerte el azt is, hogy $>>$ természetesen nincs egyéb garancia $<<$, mint csupán ez a tisztről való benyomása; de, mondta, hogy pillanatnyilag ennyivel kell beérnie, s nem hiszi, hogy tévedett volna. Föltéve - tette még hozzá -, ha nem csal az emberismeretem -, de inkább úgy, hogy a magam részéről legalábbis, ezt az eshetőséget csakugyan, meglehetősen valószínütlennek éreztem.” (88.) 
Az elbeszélésmód, pontosabban az „emlékezésmód” egyre szatirikusabbá váló iróniája a sors növekvő hatalmával egyenes arányban nő, és minél rejtőzködőbb és erősebb az utóbbi, annál nyíltabban és kíméletlenebbül munkálkodik az előbbi. Az Auschwitz felé tartó vonatút során az „utolsó”, a magyar határnál feltűnő csendőr ,,jó szándékáról” már nehéz nem ironikusan értesülni, aki állítólagos víz-monopóliumáért cserébe még a maradék értéket is ki akarja zsarolni a szállítmány tagjaiból, de nem jár „sikerrel”; és akinek végső, vaktában odavetett ítélete megint csak a kegyetlenül szatirikus-ironikus jóslat-funkciót tölti be: „S fölháborodástól meg utálkozástól is csak úgy fulladozó hangon ezt a kívánságot intézte még hozzánk: - Akkor dögöljetek csak szomjan! - Később különben ez meg is történt - a mi kocsinkban legalábbis így beszélték. [...]” (95.)

Az utólag-történelmileg önmaga földrajzi jelentőségét jócskán túlnövő, csak a vallási szimbólumok erejével összevethető Auschwitz (Oswiecim) nevet viselő városkába való érkezés során az újra csak az alvilági homályt idéző hajnali látképbe a napfény mint az ítélet trombitaszava, és egyúttal mint a nietzschei hatalomakarás hajnalpírja világít be. Csak a történelemfilozófiai perspektíva teszi nyilvánvalóvá az itt rejtetten jelenlévő torzulásokat. A képi-gondolati vonatkozásaiban gazdag, finom iróniával dolgozó leíró prózai betét ezúttal már nem pusztán a szereplő Köves Gyuri tapasztalati horizontját meghaladó elbeszélő közbeszólása, hanem az írói reflexiós technika pillanatnyi megmutatkozása is az elbeszélés szövetének felfeslése mögül. „A hajnal odakinn hűvös és jó illatú volt, a széles mezők fölött szürke ködök, majd váratlanul, de akárcsak egy trombitaszó, éles, vékony, piros sugár érkezett mögülünk valahonnan, s megértettem: a napfelkeltét láttam. [...] Láttam, mégpedig két szót is a kezdődő fényben, az épület keskenyebbik, a menetirányunkkal szembenéző oldalának tető alatti felületén: >>Auschwitz-Birkenau<< - ezt olvastam, a németek hegybogas, cirkalmas betűivel írva, a duplán hullámos választójelükkel összekötve.” (97-8.) 
A Platón barlangjából kiszabaduló, a hirtelen fénytől elvakuló filozófushoz hasonlóan a vonatból a „napfénybe, a szabad levegőre” kiugró Köves Gyuri látását is elhomályosítja az auschwitzi „,igazság” egyelőre befogadhatatlan felfénylése: „Mindjárt el is vakultam kissé ettől a hirtelen tágasságtól, az égnek meg ennek a síkságnak az egyformán fehér, szememet fájdító ragyogásától.” (102.) És nem sokkal később: „A méretek, ennek a síkságnak az egész kiterjedése is megint meglepett, ahogyan körülnéztem. Már azonban - a sok ember közt meg ebben a kápráztató fényben is - igazán pontos képet nemigen nyerhettem róla..." (1056.) Együtt lélegzik ezzel a látási-befogadási nehézséggel az emlékező-elbeszélő, sőt az író törekvése, hogy a történések igazságtartalmát a történelem úgynevezett áradatából, forgatagából kinyerje. Víz alatt látni nehezebb, lélegezni pedig nem is lehet: csak a tüdődben megmaradó levegőből élsz, azt kell beosztanod, amíg tudod, amíg időről időre a felszínre tudsz jutni. Mert a gyorsan tovasodró történések legpontosabb képe az alvilágimitikus-kaotikus erőket mozgósító sztüxi vízáradat és karneváli forgatag: „,valami kásásan fortyogó, örvénylő áradat vitt, sodort, ragadott magával” (103.); „végül a nőt - vagy még leányt inkább - az áradat szakadatlan ostroma valahára mégiscsak leválasztotta, elvitte és magába nyelte” (104.); „,[m]indezek a képek, hangok, események meg is zavartak, el is szédítettek kissé ebben a végezetül már egyetlen furcsa, színes, mondhatnám, bolondos benyomássá összekeveredő forgatagban; más, meglehet, fontosabb dolgokat ezért is voltam csak kevésbé képes figyelemmel kísérni...” (104.) A képek, hasonlatok tendenciózusan mitikus, félelmetes természeti elemként ábrázolják az auschwitzi gépezetet (gondoljuk csak meg, mennyivel gyakoribb ez utóbbi gépezet-metaforika a történeti vagy esztétikai leírásokban a koncentrációs táborok kapcsán; a Sorstalanságban azonban csak elvétve bukkan fel: a következö, vonattal kapcsolatos hasonlat is csak megszorításokkal sorolható ide). 
A hatodik fejezet elején, mikor Köves Gyuri első, huzamosabb ideig tartó munkatáborába, Zeitzba kerül, a vonat metaforája még magába süríti az Ananké (álló vonat) és a Tükhé (robogó vonat) képzeteit: „Csak Zeitzban láttam be, hogy a rabságnak is vannak hétköznapjai, sőt, hogy az igazi rabság csupa szürke hétköznap tulajdonképpen. Mintha már lettem volna efféle helyzetben körülbelül, mégpedig a vonatban egyszer, még Auschwitzba menet. Ott is az időn, no meg kinek-kinek a maga képességein múlt minden. Csakhogy Zeitzban - hogy példámnál maradjak - azt kellett éreznem: megállt a vonat. Más oldalról viszont $-\mathrm{s}$ ez is igaz - meg oly sebességgel robogott, hogy követni se bírtam a sok változást, előttem, körülöttem, de még saját magamban is. Egy valamit legalább elmondhatok: magam részéről a teljes utat megtettem, minden esélyt, ami csak ezen az úton adódhat, becsülettel kipróbáltam.

Mindenesetre új dologba legelsőbben mindenütt, még egy koncentrációs táborban is jó szándékkal fogunk - én legalábbis így tapasztaltam: egyelőre elegendő jó rabbá válnom, a jövendő majd azután meghozza a többit...” (171-2, kiem. tőlem)

A felkínálkozó összes lehetőséget (a Tükhé minden felfénylését) megragadni, hogy jó rab legyek - ez a (végső soron ,„polgári”) program Köves Gyuri számára hamar kivihetetlennek mutatkozik. Ahogyan a kortárs büntetés-végrehajtásnak sem célja az, hogy jó rabokat teremtsen (a reszocializáció vagy reintegráció terminusaival körülírható eljárás eszményi célja talán az „engedelmes állampolgár” fogalma alá hozható), úgy a megsemmisítés célját kitűző (bár nevében ezúttal a „munka” terminusával a valódi célt úgy-ahogy, a maga cinizmusával elfedő) tábor sem akar magának jó rabokat, annál inkább megsemmisítetteket.

Az egyelőre szelíden jelentkező zeitzi vonat-hasonlatnál árulkodóbban hirdeti az Anankéképzet korlátlannak mutatkozó hatalmát egy korábbi, az ötödik fejezetben elmesélt epizód, 
amely azt is egyértelművé teszi, hogy ez a totális sorsképzet még jobban uralkodik az elnyomókon (megsemmisítőkön), mint az elnyomottakon (megsemmisítésre szántakon). (És lényegében, ebben az izolált helyzetben, az előbbieken keresztül uralkodik az utóbbiakon.) A gázkamrákban való meggyilkolást megelőző eljárásról van szó, amelynek során a hatalom ágensei a legkörültekintőbb figyelemmel próbálják elterelni a megsemmisítésre szántak figyelmét elkerülhetetlen sorsukról. Tadeusz Borowski elbeszéléseiben vagy Claude Lanzmann Shoah címü filmjében is találkozunk ezzel a jelenséggel. Miért van szüksége a rendszernek ezekre a kínosan aprólékos látszat-intézkedésekre? A magától értetődő válasz az lenne, hogy tudatlanságuk révén kevesebb ellenállásra számíthat a megsemmisítésre szántak részéről, valamint hatékonyabb hullatermelést remélhet. Gyakori is ez a magyarázat, mely azonban talán egyszerre túl sokat és túl keveset magyaráz meg. Az intézkedések túlburjánzó aprólékossága némileg ellentmond ugyanis a gazdaságosság egyébként egyre szigorúbban és minden téren érvényesülő követelményének. De nemcsak erről van szó: a barokkos áradatú hazudozás és a látszatintézkedések nem pusztán pragmatikus/operacionális célokat szolgáltak, hanem azt a tudattalan szeméremérzetet, azt a szégyenérzet eltitkolására való igényt is bizonnyal kielégíthették, mely az egyéni (vagyis az egyetlen valós) felelősségtől menekülő, a parancsra gyilkoló/büntető/élő démonikus ember („emberalatti”, vagyis csakis hierarchiában értelmezhető ember) eloldozhatatlan sajátja. ${ }^{46} \mathrm{~A}$ démonikus rend által uralt lélek legemésztőbb gondja mindig is a szellem (a szabadság) elfojthatatlansága, melyből a felelősség átruházási kísérleteinek feltartóztathatatlanul egymásra következő kudarcai származnak. Ezen a ponton érintkezik a megsemmisítő

\footnotetext{
${ }^{46}$ A modern igazságszolgáltatás és büntetés-végrehajtás egyik alapmotívumaként többször hangsúlyozza egy hasonló szégyenérzetnek a jelenlétét Michel Foucault Felügyelet és büntetés címü könyvében. „A modern igazságszolgáltatás és végzői szégyellik, hogy büntetnek, bár ez nem mindig zárja ki a buzgóságot; ez a szégyenérzet szüntelenül növekedik; ez az a seb, amely körül a pszichológusok és az erkölcsi ortopédia kishivatalnokai nyüzsögnek.” Michel Foucault, i.m., 17-18. Persze alapvető különbség a modern igazságszolgáltatás és a nemzetiszocialista totális büntetés-végrehajtás között, hogy utóbbi nem igényelte, sőt nyilvánvalóan kizárta, hogy az ,erkölcsi ortopédia kishivatalnokai” nyüzsögjenek az okozott seb körül.
} 
táborok közösség-lélektani alapállása a késő középkori és kora újkori összeurópai boszorkányhisztériák hangoltságával.

„A hisztérikus lélek keres valakit - vagy valakiket -, akikre minden felelősséget ráháríthasson, s magát minden felelősség alól felmentse: mumusokkal népesíti be maga körül a világot. Ugyanúgy, ahogyan a primitív ember az öt érő természeti szerencsétlenségeket, melyeknek okait a maga tapasztalati anyagával megmagyarázni nem képes, intencióval ruházza fel, mágikus erőknek, rosszindulatú szellemeknek tulajdonítja. [...] A hisztérikus ember és a hisztérikus közösség e tekintetben teljesen úgy viselkedik, mint a primitív, csak éppen a primitív nem képes megérteni az igazi okokat, a hisztérikus pedig nem akarja megérteni őket." - írja Bibó István A német politikai hisztéria okai és története című mértékadó munkájában ${ }^{47}$. Ha az etika kérlelhetetlensége felöl közelítünk ehhez a problémához, akkor az ítéletet a következőképpen foglalhatjuk össze: a hisztérikus, avagy démonikus léleknek (ellentétben a primitívvel, az ,ártatlannal”) nincs és nem is lehet mentsége. De pszichológiailag, akár empátiával is, mindenesetre mindenképpen (müvészileg) közvet(ít)ett módon közel lehet férkőzni hozzá; hiszen részben erről szól, és ezért megbotránkoztató mai napig is a konformista (önmagát bármennyire is „toleránsnak” gondoló vagy képzelő) tudat számára Jean Améry, Tadeusz Borowski vagy épp Kertész Imre munkássága.

Köves Gyuri képzeletében nem hiába egy felelőtlen diákcsínyhez válik hasonlatossá ez a gondosan kitervelt operáció. Az sem véletlen, hogy az elbeszélő emlékezése szerint, és ezt esküvel is sietne nyomatékosítani, az auschwitzi, később átmenetinek bizonyuló barakkjához tartó úton, rabéletének első, általa is tudatosult napján senki idegennel nem beszélt (139.), pontosabb értesülései mégis ezen az úton, mintegy „pletykálásra”

\footnotetext{
${ }^{47}$ Bibó István: „A német politikai hisztéria okai és története.” In Bibó i.m. 9-76. (17.) (1942-44)
} 
hagyatkozva alakultak ki - mintha csak leütésre kínálná az elbeszélő a magas labdát az úgynevezett holocaust-tagadók szemellenzős bornírtságának (akiknek egyikével a zárófejezetben (306-7.o.) majd találkozik is a főszereplő): „Mindez nem egyszerre, inkább apránként jutott értésemre, mindig újabb részletekkel kiegészülve, némelyeket vitatva, másokat helybenhagyva, s újabbakkal is megtoldva.” (140.) A szatirikus kardél ritkán vágott irodalomban olyan kegyetlenül és ritkán ejtett olyan mély sebet, mint a következő sorokban (és van még néhány hasonló szöveghely, amelyet ezúttal nem idézek) - és emiatt, nem pedig valami tételesen artikulált filozófia miatt (hiszen mủalkotás nem nyújthat közvetlenül filozófiai tant, legfeljebb tiszta formára hozott problémafelvetésével utalhat rá) indokolt azt mondani, amit Spiró György egyébként jó érzékkel megjegyzett a könyv kapcsán, miszerint az „már-már az irodalom korlátait is szétrobbantja”48: „Ott szemközt jelen pillanatban épp a mi vonatunkból való útitársaink égnek, mindazok, akik autóra kérezkedtek, akik továbbá öregség vagy egyéb ok miatt az orvos elött alkalmatlannak bizonyultak, valamint az aprónép és velük jelen vagy eljövendő anyák, akiken ennek már látható a jele, amint mondták. Az állomásról ők is a fürdőbe mentek. Öket is fölvilágosították a fogasokról, a számokról, a fürdés módozatáról, ugyanúgy, amiképpen minket. A borbélyok is ugyanúgy ott voltak - mint állították -, és a szappant is a kezükhöz kapták. Aztán ők is bejutottak a fürdőhelyiségbe, ahol, hallom, ott is ugyanúgy megvannak a csövek meg a zuhanyok: csakhogy ezekböl ott őrájuk nem vizet, hanem gázt engednek. [...] Közben - hallom végig igen szívesek hozzájuk, gondoskodás, szeretet veszi őket körül, a gyermekek labdáznak meg énekelnek, s az a hely, ahol megfullasztják őket, igen szép, gyep, liget meg ágyások közt fekszik: ezért is keltette mindez némiképp bizonyos tréfák, valahogy affajta diákcsíny érzését bennem. Ehhez járult még hozzá, ha meggondoltam, hogy mily ügyesen öltöztettek például engem is át, csupán a fogas meg a rajta lévő szám ötletével, vagy mint

\footnotetext{
${ }^{48}$ Spiró György: „Non habent sua fata. A Sorstalanság - újraolvasva. In Élet és Irodalom, 1983/30.
} 
ijesztettek rá a tulajdonnal bírókra például a röntgennel, ami végezetül is puszta szó maradt mindössze. Persze, beláttam, mindez mégse egész tréfa, ha más oldalról nézem, hisz az eredményről - hogy így fogalmazzam - a magam szemével, meg főképp az egyre hánytorgó gyomrommal is meggyőződhettem; de hát ez volt az érzésem, s alapjaiban - így képzeltem legalábbis - ez se igen történhetett oly nagyon másként. Végtére is csak itt is összeültek, mondhatnám: összedugták a fejüket igen valószínüen, ha ugyan nem is épp diákok, természetesen, hanem meglett, felnőtt emberek, esetleg, sőt minden bizonnyal, ha meggondolom, urak, tekintélyes öltözékben, szivarral, rendjelekkel, csupa parancsnok vélhetően, akiket e percben nem lehet zavarni - így képzeltem. Egyikük aztán kigondolja a gázt: egy másik mindjárt a fürdőt, egy harmadik a szappant, egy negyedik megint a virágokat teszi hozzá, és így tovább. Némelyik ötletet esetleg huzamosabban vitathattak, javítgathattak, míg másoknak viszont mindjárt megörültek, s felugorva (nem tudom, miért, de ragaszkodtam hozzá: felugrottak) egymás tenyerébe csaptak - mindez igen jól elgondolható volt, legalábbis az én számomra. A parancsnokok képzelete aztán sok buzgó kéz, nagy sürgés-forgás nyomán válik valósággá, s a mutatvány sikeréhez, látnom kellett, semmilyen kétség nem férhet.” (139-41.)

Ha elgondolkodunk a szentkúti, a magyar holokausztra vonatkozó végső döntés minden valószínűség és beszámoló szerint kellemes és baráti körülményeiről, az emlékező-elbeszélő Köves Gyuri nekilóduló képzelete nem is állhat annyira távol a valóságtól. Az egyénített itt és most perspektívája azonban ebben a szövegrészben hatalmasra nyílik, mind ami a térbeli, mind ami az időbeli összefüggéseket illeti, azonban a pillanat örökkel randevúzó parányává sürüsödik, amennyiben a döntés etikai kategóriája felől nézzük. Más szavakkal szólva: a döntés és kitervelés banális-szatirikus, ám egyszersmind naiv igényü ábrázolása arra is utal, hogy a legapróbb, legtriviálisabbnak tünő tettben vagy mulasztásban is benne van, mint egy 
eltüntethetetlen parány, az egész Soa. És a Sorstalanság nyelvi müködése időről időre meg is nyitja ezt a perspektívát hasonló alattomossággal, bár az elbeszélésmód más ritmikájával, mint például ahogy azt Tadeusz Borowski elbeszélője, az elgázosítandó emberanyagot, „transzportot” fogadó és terelő táborlakó hangján és perspektívájából megszólaló elbeszélő műveli Hölgyeim és Uraim, parancsoljanak a gázba fáradni című elbeszélésében. Utóbbi esetben sokkal gyorsabbnak és hirtelenebbnek tünik ez a mozgás, föként az egyébként is gyors „vágásokkal” dolgozó jelenetezés miatt is. Az áradó víz metaforája itt is feltünik, amely még élesebb kontrasztot jelent, ha belegondolunk a többnapos, akár egy hétig tartó étlen-szomjan-zsúfoltan eltöltött vonatút után a levegőtlen kocsikról leszédelgő (vagy bizonyos esetekben holttestként lezuhanó) emberek szomjúságának valójában elgondolhatatlan mértékébe. Az elbeszélésmód hirtelen fokalizációs tágulása révén az itt és most érzetét keltő elbeszélés csaknem észrevétlen, alattomos és gyors lépések során történelmi távlatúvá nyílik, a történések sodrásában szinte képtelennek tünő mozgással előreszalad egy tágas retrospektív perspektíva mögé, hogy aztán újra visszaszüküljön a szemtanú és résztvevő szituációtól eloldozhatatlan nézőpontjára, aki megkapja a tetthely megtisztítására vonatkozó parancsot az illetékes SS-tiszttől. „A tábor íratlan törvényei alapján a halálba menőket az utolsó pillanatig becsapjuk. Ez az irgalom egyetlen megengedett formája. Irtózatos hőség van. [...] Tarka tömeg özönlik ki a vagonokból, akár az ostoba, vak folyó, amely új medret keres magának. De mielőtt a friss levegőtől, a fák illatától kijózanodnának, már elvesszük csomagjaikat, lehúzzuk róluk a télikabátot, az asszonyok kezéből kitépjük a retikült, az esernyőt. [...] Mögöttünk egy SS áll, nyugodt, fegyelmezett, hivatalos. [...] A hangja csupa gyöngédség, a karcsú nádszál idegesen hajlong a kezében. [...] Egy asszony lehajol, felkap egy retikült. Zizzen a nádpálca, a nő felsikolt, megbotlik, a tömegbe zuhan. Az utána futó kisgyerek vékonyka hangon kiáltja: „Anyuci”aprócska, borzas hajú kislány. 
Szaporodnak a bőröndök, batyuk, hátizsákok, plédek, ruhanemük, retikülök, a földre hullva szétnyílnak, szivárványszínü bankjegyek, órák és arany fordul ki hasukból, a vagonajtók előtt kenyérhegyek magasodnak, csillognak a lekvárosüvegek, gyülik a sonka, kolbász, a kavicsot cukor borítja. Az emberrel megtömött autók pokoli berregéssel hajtanak el, asszonyok jajveszékelésétől, gyermekek sírásától s a hirtelen magukra maradt férfiak ostoba hallgatásától kísérve. Azok, akiket jobbra küldtek, a fiatalok, az egészségesek, a lágerbe mennek. Majd ők is gázba kerülnek, de előbb megdolgoztatják őket.

A teherautók térülnek-fordulnak, pihenés nélkül. Szünet nélkül szirénázik a vöröskeresztes autó. A motorházra festett hatalmas, véres kereszt olvadozik a melegben. Fáradhatatlanul nyeli a kilométereket: szállítja a gázt, amivel majd megölik ezeket az embereket.

A lépcsőnél álló kanadásoknak egy percnyi pihenőjük sincs, ők választják külön a gázba menőket azoktól, akik a táborba mennek, az előzőket a lépcsőre tuszkolják, majd a teherautóra gyömöszölik, mindegyikre körülbelül hatvanat.

Oldalt simára borotvált fiatal SS áll, kezében jegyzetfüzet; valahányszor kigördül egy autó, kis vonalat húz a füzetbe, tizenhat autó durván ezer ember. Az SS pontos, árad belőle a nyugalom. Nem megy el autó az ő tudta, no meg a kis vonalka nélkül: Ordnung muss sein. A kis vonalak ezressé tömörülnek, az ezrek egész transzportokká, amelyekről majd röviden így emlékeznek meg: a ,thesszaloniki”, a „strassbourgi”, a „rotterdami” transzport. [...] A transzportok hetekké, hónapokká, évekké szaporodnak. Ha véget ér a háború, számba veszik az elégetetteket. Négy és fél milliót számolnak össze. A háború legvéresebb ütközete, az egy emberként küzdő, egyesült Német Birodalom leghatalmasabb győzelme. Ein Reich, ein Volk, ein Führer - és négy krematórium. De Auschwitzban tizenhat, naponta ötvenezer ember elégetésére alkalmas krematórium épül. A tábor terjeszkedik, míg csak árammal telített drótkerítése meg nem torpan a Visztula partján, háromszázezer rabruhás ember lesz a 
lakosa, s Verbrecher-Stadtnak, a Bünözők Városának keresztelik. [...] Kiürültek a vagonok. A sovány, himlőhelyes SS nyugodtan benéz a kocsiba, kelletlenül csóválja a fejét, végignéz rajtunk, és befelé mutat. - Rein! Tisztítsák ki!"49

$* * *$

Részösszegzésképpen megismétlem: a felgyorsított és tökéletesített fegyencszocializáció, valamint a halálbüntetés lappangva is sarkalatos természete a büntetőjog és a büntetésvégrehajtás struktúrájában nem jelenti azt, hogy a modern büntetés-végrehajtásnak kifejezetten, operacionálisan követendőnek tekintett mintaképe lenne a koncentrációs táborok gyakorlata, de azt bizonyosan, hogy az előbbiben részben nyíltan, de még inkább rejtetten munkáló tendenciák a legkorlátlanabbul az utóbbiban jutottak érvényre. Jelenleg is müködő börtöneinkben nem elvi lehetőségként, absztrakcióként vagy barbár fenyegetésként, hanem csökevényes formában bár, de a lehető legreálisabban van jelen a koncentrációs táborok gyakorlata. Amellett talán már nem kell érveket felsorakoztatnom, hogy a modern büntetés-végrehajtás és a modern demokratikusnak nevezett jogállam egymástól elválaszthatatlanok. A koncentrációs táborok a modern, jelenleg is érvényben lévő büntetésvégrehajtás önmaga előtt is titkolt eszményét leginkább megközelítő intézmények voltak. Ez az eszmény nem más, mint a jó eszményének (a par excellence etikai ideának) torzult formája. Állami-jogi úton, valamint ettől elválaszthatatlanul büntetőjogi úton elérendő közjóvá torzult formája. Az erkölcsi ítélet, az igazságosság bensőségességének, spontaneitásának összezagyválása a büntetőjogi ítélet külsődleges természeti következményeivel történelmileg (hogy az irónia is megkapja a maga jussát:) végzetesnek bizonyult. Az eredendő bűn vallási dogmájának jogi-hatalmi, torzult értelmezése teljes

\footnotetext{
${ }^{49}$ Tadeusz Borowski: „Hölgyeim és Uraim, parancsoljanak a gázba fáradni”. Ford. Fejér Irén. In Tadeusz Borowski: Kövilág. Válogatott versek és elbeszélések. Budapest: Múlt és Jövő Kiadó, 1999. 211-213.
} 
diadalt ült, és ez a természeti „bün” fogalmának teljes feloldódásához vezetett. Valóban maga a létezés vált bünné. Történetesen többek között a szellemi és fizikai fogyatékosként, homoszexuálisként, valamint a még elmosódottabban meghatározható (de annál nagyobb meghatározási „szabadságot” biztosító!) zsidóként, cigányként való létezés, de ezen a sémán belül bünné válhat mindenfajta természetivé tett és nemcsak deviánsként értelmezett létezés, például a koldusként vagy királyfiként való létezés éppúgy, mint a cigányként vagy zsidóként való létezés; és minden jogilag-hatalmilag, tehát természetileg bünössé tett létezést jogilag-hatalmilag, a természeti élet feletti korlátlan hatalom kinyilvánításával kell megbüntetni. A jog és a (mitikus eredetü) erőhatalom közös és végső soron szétbonthatatlan eredete a maga leplezetlenségében nyilvánult meg a megsemmisítő-táborok gyakorlatában. Persze csak azután, miután fény derült ennek a gyakorlatnak a természetére, és ez utóbbi cseppet sem volt szükségszerü, hiszen a táborok müködtetői éppen a nyomok eltüntetésére törekedtek. Értelmezésem szerint eme belátás szerteágazó és szétburjánzó következményeinek érvényes és formailag teljes ábrázolása a Sorstalanság című könyv (logikai értelemben) negatív civilizációtörténeti, illetve történelemfilozófiai, fogalom- és ismeretkritikai hozadéka. A pozitív hozadékról később lesz szó.

Köves Gyuri történetére pontosabb azt mondani, hogy csak a lehető legközelebb jut el ehhez a torzult eszményhez, hiszen a tényleges megsemmisülésig nem jut el (ez esetben magától értetődően történet sem lenne), vagy, még pontosabban, a haszid történetek nyelvén szólva, ebből a Semmiből újabb Valami lesz: „valami szokatlan, rendellenes, valami félszeg, mondhatnám ügyetlen érzés - meglehet, a szeretet tán, azt hiszem.” (Sorstalanság, 235.) Mert a bün fogalmának teljes feloldódásában valami ügyefogyott remény is megmutatkozik. 
Amikor az elbeszélő-emlékező felidézett és megidézett énje a legközelebb jut a megsemmisüléshez, a sáros földön mozgásra képtelenül, már fájdalmat sem igen érezve, a Buchenwald fölötti szürke eget nézegetve megtapasztalja a koncentrációs táborok sajátos, az Immanuel Kantéhoz képest kevésbé kontrasztos, szürkébb transzcendenciáját. Az etikai szférát, a logosz voltaképpeni emberi tartományát már rég elárasztotta a fizikai tehetetlenség és a puszta túlélési ösztön homályos, ám minden megfontolást uraló késztetése. A szabad ég, valamint a fény-sötétség kettőssége mindenesetre ezt a képet is uralja. A szürke felhőzetet meghasító „fényesebb lyuk” a tehetetlenségében immár békésen el-eltűnődő Gyurit az élet és halál fölött ítélkező auschwitzi orvos szemére emlékezteti. Ez olyan volt, írja az emlékező-elbeszélő, „mint valami mélység hirtelen sejtelme, amelyből ilyenkor mintha egy sugár vetülne odaföntről rám, egy gyors, fürkész tekintet, egy meghatározhatatlan színü, de mindenesetre kétségkívül világos szem - némiképp egy kissé az orvoséhoz hasonló, aki elébe egykor, még Auschwitzban kerültem.” (236.). Az orvos és Gyuri sajátos szemkontaktusáról és az előbbi szürkéskék eget idéző szemszínéről még a negyedik fejezetben értesülünk: „Az orvoshoz is mindjárt bizalmat éreztem, mivel igen jó megjelenése s rokonszenves, hosszas, borotvált arca volt, inkább keskeny ajkakkal, kék vagy szürke, mindenesetre világos, jóságos tekintetủ szemmel. Jól megnézhettem, mialatt ő meg a kesztyüs kezét kétoldalt az arcomhoz támasztva, hüvelykjével a szemem alatti bőrt húzta kétoldalt kissé lejjebb...” (110.) Az auschwitzi orvos élet és halál fölött bitorolt orvosi-bírói (panoptikus) hatalmat képviselő tekintetében az isteni ítélet és kegyelem látszata tükröződik vissza torzultan, „túlságosan is emberi” módon, túlságosan szürkén, a koncentrációs táborok látszatvilágában - ,jóságosan”. A szem szimbóluma ezúttal a gnózis misztikus beavatását, az ezoterikus-intellektuális szemléletet idézi, az emberi tudás túlságos magabízását; a fény-sötétség kettősével homályosan-sejtelmesen jelző ég pedig torzult, de, ha szabad így fogalmaznom, az etikai idea fényének eloldozhatatlan árnyéka szempontjából 
a legérvényesebb ábrázolási formában nemcsak Kant erkölcsi élményének homályosabb, elhallgatott oldalát, hanem a kizárólag negatívan megnyilvánuló, a démoni világrenddel leszámolni szándékozó agnosztikus szókratészi daimónt, ez esetben és így tehát a démonikusat is. És megidézi mind a formális, mind a daimonikus etika elégtelenségét is. Az auschwitzi orvos operacionális szeme számára érzékelhetetlen az etikai idea józan fénye jóllehet szemének fénye is ezen idea szürkülő, démonikus homályba vesző árnyéka miatt tünhet fel ,jóságosnak”. Kant párhuzama a csillagos ég és az erkölcsi törvény (a kategorikus imperatívusz, a formális parancs) között jelenik meg. Kant ege éjszakai ég: az éjjel minden mást, minden „fölöslegest” és „értelemzavarót” elrejt, és az éjszaka sötétjében (az önmagát izoláló „világi szerzetes”-individuum üres formájában) világosan megkülönböztethetően világít a parancs, az etikai idea vezérlő csillag-konstellációja ${ }^{50}$. Nem véletlen, hogy $A$ gyakorlati ész kritikájának zárszavában, a csillagos ég és az erkölcsi törvény párhuzamáról szóló, oly gyakran idézett mondat után rögtön a homály elleni védekezésről ír a szerző: „Kedélyemet két dolog tölti el egyre újabb és fokozódó csodálattal s tisztelettel, minél gyakrabban és kitartóbban gondolok rájuk: a csillagos ég fölöttem és az erkölcsi törvény bennem. Egyiket sem szabad mintegy homályba vagy fantasztikumba burkolva, látókörömön kívül keresnem, és pusztán sejtenem; magam elött látom, s közvetlenül létezésem tudatához kapcsolom őket." ${ }^{51}$ Mintha csak sosem volna felhős az ég. ${ }^{52}$ Csakhogy:

\footnotetext{
${ }^{50}$ Walter Benjamin A német szomorújáték eredete címet viselő munkájának ismeretkritikai előszavában nem csillagokhoz, hanem csillagképekhez hasonlítja (legalábbis viszonyjelleggel) az ideákat. Érdemes ezt a szakaszt hosszabban idézni, mert többek között a törvény és idea világos szétválasztásával a kanti etika kritikai kiegészítését készíti elő, jóllehet vagy éppen emiatt terminológiájában mutatis mutandis sokat kölcsönöz onnan: „Az ideák úgy viszonyulnak a dolgokhoz, mint a csillagképek a csillagokhoz. Ez először is azt jelenti: az előbbiek az utóbbiaknak sem fogalmai, sem törvényei gyanánt nem értelmezhetők. Nem a jelenségek megismerésére valók, s a jelenségek semmiképpen sem szolgálhatnak az ideák állagának kritériuma gyanánt. A fenomének jelentősége az ideák szempontjából inkább a jelenségek fogalmi elemeiben merül ki. Miközben a jelenségek létük, közös mivoltuk, eltéréseik révén meghatározzák az őket felölelő fogalmak terjedelmét és tartalmát, az ideákhoz füződő viszonyuk annyiban a fordítottja ennek, hogy az idea a jelenségek - helyesebben szólva azok elemeinek - objektív értelmezéseként határozza meg elöször ezek egymáshoz tartozását. Az ideák örök csillagállások, s amikor úgy fogjuk fel az elemeket, mint pontokat az effajta konstellációkban, felosztottuk és ugyanakkor megmentettük [gerettet] a jelenségeket.” (204-5. GS 1, 212-3.)

${ }^{51}$ Immanuel Kant: A gyakorlati ész kritikája. Ford. Berényi Gábor. Budapest: Cserépfalvi, 1996. 213.o.

52 „A német fasizmus elméletei. Az Ernst Jünger szerkesztette $>>$ Háború és harcos $<<$ címü gyüjteményhez” címü németül 1930-ban megjelent írásában Walter Benjamin akkor már halott barátja, a protestáns teológus,
} 
bár az etika szava világos, de nem az övé az utolsó, sem nem az első szó. Az etika a logosznak lehet megismerője, de nem teremtője. A logosz, a legtágasabban értett nyelv, a „teremtés nyelve”, a „valóság”, a „szituáció” megelőzi az etikát, mely utóbbi aztán a bün felmerülése nyomán megismerési igényével mintegy visszahajlik a nyelvre, a „valóságra”, a „szituációra”. És: az etika valójában a veszély helyén (leginkább: a halál közelében), a „szituációban” nyilatkozik meg, nem a törvény puszta formájában. A látókörömön kívüli sejtelem akkor is megelőzi és bevégzi az etikai reflexiót, ha nem esek bele a Kant által leginkább rettegett miszticizmus, szellemidézés vagy dogmatizmus szakadékába. Kant csillagos egéhez képest a Buchenwald fölötti szürkébb ég épp azt jelzi, hogy a látszólag oly kontrasztosan megmutatkozó kategorikus imperatívuszban, annak legbensejében mindig marad valami kimondhatatlan, valami rejtetten megnyilvánuló; a titok, a hallgatás és a zárkózottság monomániás-démonikus elve a kanti erkölcs rejtett tartalmi középpontjában helyezkedik el - a kanti etika mélyen, de annál meghatározóbban megbúvó agnosztikus vonulata Wittgenstein Tractatusában teljesedik ki majd jó száz év elteltével. Az önmagát magának akaró szerzetes-fillozófusi aszketikus kedély transzcendens élményét a buchenwaldi koncentrációs tábor nedves kövezett talaján a felhalmozott, csaknem megsemmisített, halálközeli testeinek legalábbis egyikében a maga szürkébb, szegényesebb, ám nyíltabban démonikus módján, és módosult tartalommal idézi fel. A transzcendencia tartalma halál és szeretet végső rokonságának sejtelme. „Erős a szeretet, mint a halál, kemény, mint a sír a buzgó szerelem”, írja az Énekek éneke költője. (A halál és a félelem

politikus és író Florens Christian Rang szavait idézi tanúként szemben a háború „ősgermán” kultuszát hirdetőkkel: „A démonikus sorshit, hogy hiába az embererény - , a fény hatalmainak győzelmét istenek világégésében szétlobbantó dac sötét éjszakája... a csatatéri halál hitvallásának, hogy az életet semmibe véve dobjuk oda az eszméért, látszólagos akarás-pompája - , ez az évezredek óta ránk tornyosuló felhőterhes éjszaka, amely csillagok helyett csak villámot küld útmutatóul, fülsiketítő, bénító villámlást, hogy utána még sötétebben gyürüzzön körül az éjszaka: a világ-halál iszonyatos világnézete a világ-élet helyett, amely a német idealizmusfilozófiában az iszonyatot azzal a gondolattal enyhíti, hogy a felhök mögött csillagos az égbolt - a német szellemnek ez az iránya a legeslegmélyén akarat nélküli, nem gondolja, amit hirdet, meghunyászkodás, gyávaság, semmiröl-tudni-nem-akarás, élni-nem-, de halni-sem-akarás... (ein Nichtwissenwollen, Nichtlebenaber auch Nichtsterbenwollen)". Az idézet forrását nem találtam meg, a szövegben nincs jelölve. Idézi Walter Benjamin: „A német fasizmus elméletei. Az Ernst Jünger szerkesztette $>>$ Háború és harcos $<<$ címü gyüjteményhez”. Ford. Köszeg Ferenc. In WB: Angelus Novus. 613-614. 
rokonsága nyilvánvalóbb, ám felületibb. A félelem és a szeretet együttműködése az aggódás passzivitásában és a gondoskodás aktivitásában nyilvánul meg. Nem sokkal a szürke eget megidéző rész előtt: „De mondhatom, tettekkel sem takarékoskodott, kinek csak képességéből tellett, s hozzám is adogató kezek irgalmas szorgoskodása juttatta például el, ki tudná, mi távolságból, a sárgaréz konzervdobozt, mikor bejelentettem: vizelnem kell.” (Sorstalanság, 235.) A hasonló állapotokat szokás sokat mondóan a sorsközösség szóval is jelölni.) Holt tetemként látod az embert, és szeretetként az életét, ha Isten színe előtt látod. Platón Államának tizedik könyvében lezárásképpen Szókratész elmeséli a pamphüliai Ér eszkatologikus látomását. A történet palinódiának tekinthető: a tizedik könyv elején Szókratész megindokolja, hogy miért kell száműzni a tökéletes államból a költőket és a költészetet, majd ugyanennek a könyvnek és magának az államról szóló terjedelmes, sokszor inkább monológnak tetsző dialógusnak a végén maga is a költői nyelvhez fordul, amikor arról kíván beszélni, hogy mi vár az igazságtalan és az igazságos lelkekre haláluk után. „Elmondom hát, ha nem is Alkinoosznak, de egy igen vitéz férfiúnak, a pamphüliai Érnek, Armeniosz fiának, az elbeszélését. Ö ugyanis valamikor régen háborúban elesett, s mikor tíz nap múlva a már feloszlott holttesteket összeszedték, őt épen találták meg, hazaszállították, s mikor el akarták temetni, s már a máglyán feküdt, tizenkét napos hulla létére föléledt, s föléledvén elmesélte, amit a másvilágon látott. [...] Mikor ő a bírák elé lépett, azt mondták neki, hogy az ő feladata lesz majd hírül vinni az embereknek az ott történteket; tehát megparancsolták neki, hogy jól hallgasson és figyeljen mindenre azon a helyen." ${ }^{\circ 3}$ Az elbeszélés nagy része azonban az ígérettel szemben nem az igazságtalan és igazságos lelkek túlvilági sorsának a differenciálásával foglalkozik, hanem sokkal nagyobb hangsúlyt helyez az újjászületés mítoszára. Az újjászületések ritmikáját is a végzet, az Ananké orsója szabályozza; az újjászületések mozgását egy többszintű körforgás jeleníti

\footnotetext{
${ }^{53}$ Platón:,Állam.” Szabó Miklós fordítása. Platón összes művei, II. kötet. Budapest, Európa, 1984. 700.
} 
meg, melynek ritmusát és statikus polifón dallamát a szirének és a szüz, ,ártatlan” Moirák éneke adja. „Az orsó az Ananké ölében forog. Mindegyik körön fenn egy-egy szirén ül, aki a körrel együtt körben forog, s közben mindig egy és ugyanazt a hangot hallatja; a nyolc hang aztán egy összhangban zeng össze. Másik három nőalak pedig körben ül, egymástól egyenlő távolságra, mindegyik egy-egy karosszékben: ezek a Moirák, Ananké leányai, fehér ruhában, fejükön szalagdísszel: Lakheszisz, Klóthó és Atroposz, akik a szirénekkel összhangban énekelnek; éspedig Lakheszisz a múltról, Klóthó a jelenről, Atroposz pedig a jövőről." ${ }^{\circledR 4}$ Ez a körforgások és szólamok statikus és rendezett összhangzatát leíró elbeszélés egyben a félelmetes és alaktalan káosszal, a halál formátlanságával szemben álló, és azt magában feloldó, a kakofóniából harmóniát komponáló, megnyugtató kozmosz modelljét is megjeleníti. Az odaérkező lelkeket Lakheszisz fogadja, átadja nekik a sorshúzó cserepeket, melyek sorrendbe állítják őket, majd e sorrend alapján választhatnak az életformák közül. „Nem titeket fog a daimón kisorsolni, hanem ti fogtok magatoknak daimónt választani” mondja nekik Lakheszisz. De ne feledjük: ez a választás vak. A Moira szavai jellegzetesen kétértelmüek. „Mikor valamennyi lélek kiválasztotta már az életformáját, a sorsolás sorrendjében Lakheszisz elé járultak; s ő mindegyikük mellé kísérőül odaállította azt a daimónt, akit ki-ki választott, hogy az vigyázzon életére és teljesítse be választott sorsát. Ez a daimón először is Klóthóhoz vezette a lelket, s az ő keze és orsójának a pergése alatt hitelesítette azt a sorsot, amelyet az illető választott; ezt megérintve, tovább vezette őt Atroposz fonásához, hogy a megfont fonalat változatlanná tegye; innen - anélkül, hogy megfordult volna - Ananké trónjához ment, azon áthaladt, s mikor ezen a többiek is átmentek, valamennyien a Léthé síkságára vonultak, nagy forróságon és szörnyen fojtogató levegőn keresztül, mert ott sem fa, sem semmiféle növényzet nem volt. Itt táboroztak estefelé az Amelész folyó partján, melynek vizét semmilyen edény nem tudja magában

\footnotetext{
${ }^{54}$ I.m., 704.
} 
tartani. Ennek a vizéböl mindenkinek innia kellett egy bizonyos mennyiséget; de akit a józan esze vissza nem tartott, az többet is ivott a kiszabott mennyiségnél; aki aztán ivott belöle, mindent elfelejtett. Mikor lefeküdtek, s éjfél lett, mennydörögni s a föld rengeni kezdett, s ekkor hirtelen az egyik erre, a másik amarra fölfelé sodródott, szökellve, mint a csillagok, hogy megszülessék. Neki nem engedtek inni a vízből; de hogy merre és miképp jutott vissza testébe, azt nem tudja, csak reggel hirtelen fölnyitotta a szemét, s látta, hogy ott fekszik a máglyán."55

\footnotetext{
${ }^{55}$ I.m., 708-9.
} 


\section{Elpisz/Logosz}

Remény, TESz.: 1138/1329. „Ismeretlen eredetü. A remény nagyszámú korai származékai alapján feltehető, hogy jóval korábbi, mint a források mutatják. A régi nyelvben ritka szó volt, helyette a reménység származékot használták. A nyelvújítók nem ismerték, s a reménység, reménykedik stb. származékokból ismét elvonták. - Török származtatása téves.”

„KARVEZETŐ

De mondd, nem tettél semmi mást ezen kívül? PROMÉTHEUSZ Azt, hogy végóráját ne sejtse senki meg.

KARVEZETÖ

Ilyen betegség ellen mily gyógyírt találsz?

PROMÉTHEUSZ

Az emberek lelkébe loptam vak reményt."

Aiszkhülosz: Leláncolt Prométheusz (Trencsényi-Waldapfel Imre ford.)

„... a csöppség csak áll, csak áll reménytelenül, vagy van remény a pusztai harangvirágban, amint áll a hajnalban és rezegve nyílik a nap alatt?”

Móricz Zsigmond: Árvácska 
Idézzük fel újra azt, amit Walter Benjamin a halálbüntetés jelentőségéről ír a jogi erőhatalom vonatkozásában: „A halálbüntetés az, amelyik a leginkább kihívta maga ellen a kritikát, amióta a pozitív jog érvénye kétségessé vált. A halálbüntetés mellett szóló érvek a legtöbb esetben nem voltak lényegbevágóak, de a mögöttük rejlö indítékok mindig elvi jelentőségüek, és azok is maradnak. A kritikusok érezték - bár talán nem tudták volna megindokolni, sőt valószínüleg érezni sem akarták -, hogy a halálbüntetés elleni támadás nem egy büntetőjogi tételt, nem törvényeket, hanem magának a jognak az eredetét kezdi ki. Ha ugyanis a jog az erőszakból, a sorsszerüen megkoronázott erőszakból ered, akkor nem nehéz megsejteni, hogy a legfőbb, az élet és halál fölötti erőhatalomban, ott, ahol az megjelenik a jogrendben, a jog eredete ütközik ki reprezentatív módon a már fennálló viszonyokon, és termékeny módon megnyilvánul bennük. [...] De a halálbüntetésnek valójában nem az az értelme, hogy megtoroljon valami jogsértést, hanem az, hogy új jogot statuáljon. Mert az élet és halál fölötti hatalom gyakorlásával sokkal inkább megerősítést ad magának a jog, mint más büntetések végrehajtásával.” Az ítélkezés korlátlan uralmát a halálbüntetésnek a modern jogi berendezkedésben immár látenssé vált strukturális alapja biztosítja be a jogi erőhatalom számára. Egyáltalán az, hogy (egy társadalmilag intézményesített funkciót ellátó) ember másik (az intézményesített funkció által redukált/definiált) ember fölött jogilag ítélkezzen, amely teljesen eltér egy cselekedet vagy mulasztás etikai megítélésétől, és amely jogi ítélkezés eredménye csakis az emberi létezés természeti (fizikai és pszichológiai) szféráját érintheti, sosem az etikait vagy ne adj' isten a vallásit, a halálbüntetésben egyértelműen és a legszélső érték felmutatásával újra-alapozó jelleggel megnyilvánul. 
A végzet szó (a bírósági értelemben vett végzés rokona) alakjában magában hordozza azt az összefüggést, hogy a triviális tudat számára a sors legbiztosabb ütőkártyája végső soron mégiscsak a halál elkerülhetetlen, egynemü egyetemessége. A nemzetiszocialista rezsim érezte ezt: a totális torz-Ananké igényével lépett fel. Torz ez az Ananké, hiszen, mint Platónnál láthattuk, a filozofikus gondolat által átvilágított mitikus eredetủ Ananké az önmagán túlnövő természet megtestesítőjeként élet és halál körforgását uralja, nem a halál egynemü egyetemességét terjeszti ki mindenre. A nemzetiszocialista rezsim azonban épp azokat az eröket totalizálta, amelyeket a posztmitikus, tehát a filozófia születésével egykorúnak tekinthető gondolkodás legyőzöttnek állított, gondolt, vagy legalábbis remélt. Bár ez a rezsim felrúgta a modern jogi eljárásrend sémáit, utóbbiak, és még inkább az általuk szankcionált büntetések ugyanazon eredetü erőkre támaszkodnak. Ha azonban ezeknek az erőknek a bosszújaként (mondjuk a polgári jogállamot érő bosszújaként) értjük a megsemmisítő-táborok múködését, akkor azon nyomban újra megadjuk magunkat az őket uraló látszat-logikának.

A Sorstalanság expozícióját záró családi búcsúvacsora két legszószátyárabb alakja, a jól értesült kispolgár ex-újságíró (és jellemzően most lóversenyirodát, szerencsejátékot üzemeltető) Vili bácsi és az „ortodox”, doktriner „vallásos” Lajos bácsi egyaránt önmaga feletti, láthatatlan erőre hivatkozva próbálja hitelesíteni mondanivalóját (mindkét figurának meglesz a maga önmaga miatt hiteles ellenpontja a könyv világában: Vili bácsié a lezáró részben szereplő riporter, míg Lajos bácsié a rabbi). A nevükben feltehetőleg nem pusztán a rokonsági fok jelzése miatt szerepel a „bácsi” kitétel, hanem családi, belterjes és a familiáris vonatkozásoktól eloldozva átlátszóan esendő tekintélyüket is mutatja a tiszteletteljes 
becézés. Vili bácsi a kereskedő kispolgár zsidó típusát hozza, szinte azt lehet mondani, százhúsz százalékkal, de éppen a túlzás révén túl is mutat a típuson a mitikus ábrázolás irányába. Minden esemény magyarázatát a gazdasági, sőt a még szükösebb piacikereskedelmi szféra kauzalitására redukálja. Más jellegű magyarázatkényszer uralja Lajos bácsit, akinek alakján keresztül az író az „ortodox” zsidó (de tulajdonképpen bármilyen, a rituálisba és dogmába merevült „,vallásos” gondolkodás) típusát mutatja be a túlzás révén. Lajos bácsi alakjának jelentősége felülmúlja Vili bácsiét. A Köves Gyurit férfivá avatni szándékozó hamis ${ }^{56}$ bar mitzvah ${ }^{57}$ jelenetben kézzelfogható a rítus mechanikus kiüresedése: Gyuri az érthetetlen ima ismétlésekor (ésszerü módon) kizárólag az érzéki ingerre képes figyelni: ,az egészből tulajdonképp csak ezeknek a nedvesen vonagló, húsos ajkaknak a látványa meg egy idegen nyelv zöreje maradt végül meg bennem” (29); itt a kép bujasága csak fokozza az érzéki benyomás uralkodó jellegét: nem kevésbé az utána következő figyelem-eltolódás a szemközti gangon tovasiető „nagyobbik nővér” látványa felé. Ez utóbbi egyben az egyik jóslatszerü kép is a történetvezetésen belül, melyek poétikai funkciója, mint már többször utaltam rá, a sorsszerüség képzetének erősítése. Lajos bácsi felvezető monológjának „filozofémái” voltaképpen ízig-vérig pogány mitikus sémákat követnek, amely sémák a fasisztoid-kispolgári gondolkodásnak is látens-elfedett alappillérei (vagyis fel sem merül bennük egy magasabb rendü szabadságfogalom lehetősége) - csak

\footnotetext{
${ }^{56}$ Hamis, mert ahogyan azt Lajos bácsi levezényli, az a vallási és pszichológiai vakság szélsőséges esete. Egy olyan gyermek számára, aki egy szót sem ért héberül, és életének kereteit eleddig nem a zsidó vallási elöírások határozták meg, az értetlenségen és az ebből fakadó zavaron kívül semmit nem jelenthet az, ha felnőtté válását számára érthetetlen szavakkal és többé-kevésbé (nyilván érti Gyuri azt, hogy imádkoznak, csak az ima tartalmát nem) értelmezhetetlen rítussal pecsételik meg.

${ }^{57}$ Lajos bácsi az emlékezö-elbeszélő által közvetített monológjának értelmezésemet közvetlenül alátámasztó részei (kiem. tőlem): „Utána viszont pár érdekes és meglepő dolgot tudtam meg tőle. Azt például, hogy életemnek egy bizonyos korszaka, amit a >>gondtalan, boldog gyermekéveknek $<<$ mondott, ezzel a mai, szomorú nappal immáron lezárul számomra. [...] Akkor a tudomásomra hozta, hogy apám távoztával mostohaanyám támasz nélkül marad, s bár a család $>>$ rajtunk fogja tartani a szemét<<, mégis, a fö támasza néki ezentúl én leszek. Bizony - mondta -, idő elött kell majd rájönnöm arra, hogy >>mi a gond és mi a lemondás $<<$. Mert hát nyilvánvaló, hogy ezentúl nem mehet majd olyan jól a sorom, mint eddig $-\mathrm{s}$ ezt nem is kívánja titkolni elöttem, mivel $>>$ felnött módján $<<$ beszél velem. - Most már - így szólt - te is a közös zsidó sors részese vagy..." (26) Vagyis Lajos bácsi meglátása szerint az apa sorsszerü eltávolítása (melyet a nemzetiszocialista logika Ananké-igénye teljességgel alátámaszt) avatja Gyurit a törvény, a parancsolatok fiává (ez a „bar mitzvah” jelentése), „felnőtté”, felelősséggel bíró emberré. Ezt talán kényszeres oktulajdonításnak nevezhetnénk.
} 
épp az ellenkező végleteken áll egymással szemben e két gondolkodásmód a sematizmuson belüli kontinuumon. Lajos bácsi „filozofémáinak” „ártatlanságát” ebben a történelmi konstellációban pusztán előadójuk zsidó származása biztosítja: „Most már - így szólt - te is a közös zsidó sors részese vagy -, majd bővebben is kitért erre, megemlítve, hogy ez a sors >>évezredek óta tartó szakadatlan üldöztetés $<<$, amelyet azonban a zsidóknak >>belenyugvással és áldozatos türelemmel kell fogadniok $<<$, minthogy azt Isten mérte reájuk a hajdani büneik miatt, s épp ezért csak Ötőle várhatják a kegyelmet is; Ő viszont addig azt várja tőlünk, hogy ebben a súlyos helyzetben mindnyájan helytálljunk, azon a helyen, amelyet Ö jelölt ki számunkra, >>erőnk és képességeink szerint $<<"$ (26-7). Itt is világosan kitünik a mitikus alaptendenciájú gondolkodásnak az a sajátossága, hogy nincsen igazságigénye. „Tényszerűen”, példák sajnos unásig elősorolható tömkelegével igazolható a zsidók ,évezredek óta tartó szakadatlan üldöztetése”, ezt sorsnak bélyegezni azonban azt jelenti, hogy lemondunk a megértésről (az igazság igényéről). Ha lemondunk az értelmezésről és a megértésröl, akkor daccal (önmagunkra kényszerített mártírszerepben, kvázi-heroikusan) türjük a ki-tudja-honnan (melyik rendőr, csendőr, kápó, SS-tiszt korbácsa által; és még inkább: melyik testetlen, jobban mondva testeket átható és körülvevő bürokratikus, ellenőrzési, felügyeleti, büntetési mechanizmus által) ránk mért sorsot, vagy kvázi-prométheuszi módon fellázadunk ellene. Itt az előbbiről van szó. Lajos bácsi „vallásos” rögeszmékkel teletűzdelt eszmefuttatása a „közös zsidó sorsról” a mitikus gondolkodás felől nézve helyes, sőt elkerülhetetlen. Éppen azért, mert annak teljességgel a foglya. Ugyanolyan „helyes”, mint a nemzetiszocialista ideológia. Tulajdonképpen ugyanazt mondják - a két véglet felöl.

Mi a különbség a mitikusba, rituálisba, dogmába merevült gondolkodás és a nemzetiszocialista világkép démonikussága között? Bibó már idézett terminusával élve többek között az, hogy utóbbi menthetetlenül hisztérikus is. A pszichoanalízis ezt a 
különbséget az elfojtás terminusával jellemezné. De ez a terminus a

problémakomplexumnak csak egy, jóllehet igen fontos aspektusát képes ábrázolni.

Történetfilozófiai dinamikával kell tetszhalott-elvont létezésükből újragalvanizálni a pszichológia és a szociálpszichológia bizonyos terminusait.

„A hisztérikus világkép zárt és tökéletes: megmagyaráz mindent, és igazol mindent, $\mathrm{s}$ mindaz, amit állít, s mindaz, amit elöír, tökéletesen megfelel egymásnak." (Bibó, 17.o.) A végletekig operacionalizálható önmagába zártság a démonikus rend által uralt hisztérikus lélek és a fasisztoid rendszerek legsajátabb vonása.

Bibó már a versailles-i békeszerződés kapcsán felhívja a figyelmet, hogy nemigen van hibásabb és terméketlenebb fellépés egy ilyen rendszerrel ${ }^{58}$ szemben, mint a morális felelősséget egyoldalúan meghatározó, büntető (sors-)logika. „A hisztérikus lelkiállapottal nem tehetünk rosszabbat, mint hogy erkölcsi ítélkezésnek és degradálásnak vetjük alá. A hisztérikus lélek amúgy is önmagából nyer kielégülést, önmagába zárt világban él, amelynek nevében mindig képes magát igazolni, az erkölcsi elítélés tehát csak arra indítja, hogy a maga hisztérikus világképét még zártabbá tegye.” (Bibó, 56. o.) A Sorstalanság elbeszélőjének alapmagatartása szereplői bemutatása során „öntudatlanul” is a magáénak mondhatja ezt a belátást (a szerzői szándéknak, ellenben, feltételezhetően igen is sok öntudatot tulajdoníthatunk ebben a tekintetben). Ezt az alapmagatartást az a csak részben technikai megoldások révén élő formai alapjegy biztosítja az elbeszélő-emlékező számára, melyet Pier Paolo Pasolini elképzelése nyomán a nem grammatikai értelemben vett szabad függő beszéd komplex terminusával írhatunk le. Erről nemsokára bővebben. Visszatérve a bibói gondolkodásra: amennyiben az erkölcsi ítélet fórum és hatáskör formájában nyilvánul meg, úgy lényegében alárendeli magát a büntetőjogi-farizeus elvnek, és spontaneitását,

\footnotetext{
${ }^{58}$ Bibó értelmezésében a weimari köztársaságot megelőző wilhelminus német birodalom és hatalomkultusz (legalábbis társadalomlélektani és politikai értelemben) organikus előzménye a nemzetiszocialista eszmék csapdájának. Hozzá lehetne ehhez tenni, mintegy átmenetként, a weimari köztársaság Hindenburg- és háborúkultuszát is. De a gondolatmenetet tágabb összefüggésbe helyezve azt mondhatjuk, hogy ez a hisztéria korlátozottabb és látensebb formában egészen mindennapos Közép- és Kelet-Európában.
} 
szituációhoz kötött érvényét, konkrét szabadságát veszíti el - absztraktummá és

abszurdummá válik. Ezt Bibó az erkölcs büntetőjogi redukciójaként határozza meg: „amikor azt mondjuk, hogy az erkölcs fórum, az erkölcs hatáskör, ezzel megfosztottuk attól a közvetlenségtől és emocionális jellegtől, ami a joggal szemben az erkölcs legnagyobb erejét jelenti, s ugyanakkor megterheltük a jogi értékítéletek jellegzetes vonásával, azzal ti., hogy bennük erkölcsi és társadalmi tények logikai állítás és tagadás ellentétévé redukálódnak.” (Bibó: Etika és büntetőjog, 169.) Ez a redukció potenciálisan fenyeget minden formális etikát, legyen bár az olyan finoman kidolgozott és pontos is, mint amilyen Immanuel Kanté.

Ha a formális etika elméleti szigorúsága is csődöt mond, akkor feltehető a kérdés, hogy végül is mi szegül ezzel a totálisan zárt látszatvalósággal, az Ananké-igénnyel, a halál egyetemességével szembe ${ }^{59}$ Egyfelől az értelem világos (morális) szava, mely, ahogy Benjamin nyomán fogalmazhatunk, minden egyes szituációban speciálisan általános érvényü, de sohasem általánosítható, nem „másolható” le, nem ,alkalmazható” egyetlen másik, mégoly hasonló szituáció esetében sem; másfelől, a legvégső esetben, a halhatatlanság reménye. De utóbbi csak addig, amíg remény, és nem igény. És e reménynek, minden remények közül a legtitokzatosabbnak és legésszerütlenebbnek, e reménynek magának is van egy belső dialektikája. Kant formális etikája a maga rendszerén belül joggal posztulálja a halhatatlanság ideáját, hiszen formálisan semmi más nem alapozhatna meg etikai igényt. De valójában úgy tűnik, hogy „,csak a reménytelenért”, csak a már meghaltakért (és más összefüggésben áttételesen is, a bennünk elhaltakért) adatott nekünk ez a remény, sosem magunkért, még élőkért (ugyancsak áttételesen: sosem bármilyen

\footnotetext{
${ }^{59}$ Bibó így folytatja a fentebbi, német politikai hisztériával kapcsolatos gondolatmenetet: „A hisztérikus világképet semmiféle erkölcsi ítélkezéssel nem lehet áttörni, csak egyetlenegy valamivel, a legdurvább és legegyszerübb tények erejével, pontosan úgy, ahogyan hisztérikusan sikoltozó nőket nem lehet fejcsóválással, erkölcsi helytelenítéssel vagy büntetéssel megfékezni, de igenis lehet egy vödör hideg vízzel.” („A német politikai hisztéria...”, 56.) Majd nem sokkal később: „Versailles volt az, mely a németekbe belegyökereztette azt a hitet - és ez a hit általános a nem hitlerista németekben is -, hogy a nemzetközi életben az erkölcsi ítélkezés lehetőségéhez nem kell más, mint egy győztes háború...” (57.)
} 
aktuális akarati vonatkozású tényezőért). E reménynek ugyanakkor az az alapvető paradoxona, hogy mégis csakis a jövőre, csakis a lezáratlanra és lezárhatatlanra vonatkozhat. Egy általános igényü müvészetfilozófia vonatkozásában érinti ezt a problémát Mihail Bahtyin A szerző és a hős című művében. A halhatatlanság kérdését előhívó, „időbeliségbe vetett” lélek esztétikai problémaként közelíthető meg. Bahtyin terminológiájában ezzel szemben a szellem az idealista filozófia „reflexív” szelleme, amelyre nem vonatkoztatható az esztétikában (az érzékelésben) meghatározó szereppel bíró időbeliség; a gnoszeológia transzcendentális én-je pedig „merőben formális jellegü”. „Ugyan most nem érintjük a vallási-metafizikai problémát (a metafizika csakis vallási lehet), de a halhatatlanság kérdése kétségkívül a lélekre vonatkozik, s nem a szellemre - az időben zajló belső életnek arra az individuális és értékhordozó egészére vonatkozik, amelyet a >>másikban<< élünk át, s amelyet a müvészetben a szavak, a színek, a hangok írnak le és ábrázolnak. A lélek közös értéksíkban van a >>másik $<<$ külső testével, és elválaszthatatlan tőle a halál és halhatatlanság momentumában (feltámadás a testtel együtt). A lélek belső adottságként, bennünk már jelenvaló, értékhordozó egészként nem létezik [ha jól értjük, ez lenne inkább itt a „szellem” hatásköre - L.Z.], magunkra vonatkoztatva nem találkozunk vele, önreflexiónkból - amennyiben a mienk - [...] nem születhet lélek, csak rossz és szétszórt szubjektivitás, olyan valami, aminek nem szabad lennie, ami a feladott értelem eltorzítása az adottságban." ${ }^{60}$ Bahtyin világosan kimondja azt is, hogy a lélek saját halhatatlanságára vonatkoztatott reménye (mely önmagában is képtelenség), magába zárva maradva, külső megerősítés híján semmis. „Az időben lezárt élet reménytelen az őt sarkalló értelem szempontjából. Egy élet a maga bensejéből reménytelen, csakis kívülről részesülhet a könyörülő igazolásban, tekintet nélkül az el nem nyert értelemre. Míg egy élet meg nem szakad az időben (az élet önmaga számára nem lezárul, hanem megszakad), belülről az a

\footnotetext{
${ }^{60}$ Mihail Bahtyin: A szerző és a hős. Ford. Patkós Éva. Bp.: Gond-Cura Alapítvány, 2004. 174.
} 
remény és hit élteti, hogy nem esik egybe önmagával, az értelem vonatkozásában önmaga előtt áll, s e tekintetben - jelenvalóságának szempontjából - az élet őrült, hiszen teljesen alaptalan ez a hit és ez a remény az élet jelenvaló létének szempontjából." ${ }^{61}$ A lélek, amelyre egyedül vonatkoztatható a halhatatlanság (és a halál) problémája, olyan azonban, mint a zsidó eszkatológia és időtudat Messiása: a jövő minden pillanata kiskapuként tárul számára, amelyen beléphet.

Bár a bizonyosság itt kizárt, mégis, elhalt, ésszerütlen remények éledhetnek újra a cselekvő emlékezés révén - a holtak emlékezete segít hozzá bennünket ahhoz, és rója ránk a felelősséget, hogy a megváltásból ilyen szerény és visszaigazolhatatlan módon kivegyük részünket. Többek között erre utalhat a „koncentrációs táborok boldogsága”, amelyről Köves Gyuri beszél, és amelyről ebben az esetben csak a „túlélő”, nem a még-nem-, hanem a már-nem-halott, az emlékezés kövét görgető adhat számot. A Sorstalanság a névtelen tömegsírokra helyezett kavics. Az emlékezés parancsa, ahogyan a könyv címe, a történelem előtt és a történet gerincén áll: a kő szimbóluma ezt ezúttal minden kétértelmüségtől mentesen, világosan mutatja. Az emlékezés csak a múltat kutathatja, de ez a kutatás a potenciálisan katasztrofális és beláthatatlan jövőre irányul. És ez a történelem tanulmányozásának alapmotívuma.

A „Köves” több és kevesebb is, mint beszélő név. A beszélő nevekhez funkcionálisan tartozó „feladat” csak ironikusan rejlik benne - mégpedig azáltal, hogy ebben az esetben a nevet először el kell veszíteni, a sors által legmélyebbre taszítva egy fegyenc sorszámára cserélni, hogy a majdan „visszanyert” (megszüntetve megörzött) névben rejlö „feladat”, az emlékezés tételeződjön. A névben rejlő másik, mitikus-alvilági jelentésréteg ott kísért a sorszámként bủnhődő elítéltben, a felfüggesztett névben is: ez pedig a követ hiábavalóan

\footnotetext{
${ }^{61}$ Bahtyin, i.m., 208.
} 
görgető Sziszüphosz alakja, a „fegyenc”, az „elítélt” archetípusa. Albert Camus írja, hogy Sziszüphoszt boldognak kell elképzelnünk. Célja a küzdés maga, anélkül, hogy bízhatna bármiben, vagyis remélhetne bármit is. De ahogyan az „emberfeletti” feladattal birkózó mitikus hérosznál több és kevesebb is az ember, úgy annak tipikus „,boldogságánál” több és kevesebb is az, amiben az ember boldogsága otthonra lelhet. Az emlékező-elbeszélő Köves Gyuri a „hegy tetején”, a zárómondat előtt a „koncentrációs táborok boldogságát” említi. Hogy itt lényegében más, a Camus által Sziszüphosznak tulajdonított boldogságtól eltérő boldogságról legyen szó, azt éppen az emlékezés biztosítja.

Az emlékezés szintén több és kevesebb is, mint feladat: a tapasztalásból kibomló parancs. Az emlékezés parancsa a tapasztalásban megismerhető/megképződő sorstalan névnek (ahogy Mihail Bahtyin mondaná: az égbe írt névnek) a beláthatatlan jövőben remélhető helyreállításával analóg. Pontosabban azzal azonos.

„Az vagyok, akit W.B.-nek hívnak, vagy pusztán egyszerüen W.B.-nek hívnak? A két kérdés egy érme két oldala, de a második elkoptatott, az első pecsétragyogású. Az első megfogalmazás azt mutatja meg, hogy a név egy bizonyos mimézis tárgya. Ám ennek a mimézisnek persze az a különös természete, hogy soha nem azon, ami jön, hanem mindig csak azon, ami volt, vagyis a megélt dolgon mutatkozik meg. Egy megélt élet habitusa: ez az, amit a név megőriz, de elő is rajzol. A mimézis fogalmával már azt is kimondtuk, hogy a név birodalma a hasonló birodalma. És mivel a hasonlóság a tapasztalat organonja, ezért: a nevet csak tapasztalati összefüggésekben lehet megismerni. Csak ezeken válik megismerhetővé a név lényege, azaz nyelvi lényege."62

\footnotetext{
${ }^{62}$ Walter Benjamin: „Passzázsok”, [Q’, 24]. In uő: „, A szirének hallgatása”. Ford Szabó Csaba. Bp. Osiris, 2001. 207. A hasonlóságról, mimézisről mint a tapasztalat organonjáról lásd ehhez: Platón: Parmenidész, 132 d
} 
A név filozófiája a nyelvi-szellemi szférában meglévő analógiája a jellem természeti (testi-lelki) kategóriájának, míg a bün filozófiája ugyanígy a nyelvi-szellemi analógiája a sors természeti (testi-lelki) jelekben megnyilvánuló kategóriájának. A büntől való elemi érintettsége révén a sors rendje abban különbözik azonban a szintén természeti jellem következetességétől, hogy előbbit teljesen uralja a démonikus, míg a jellem nonszenszkomikus következetessége, „makacssága” a démonikus-mitikus világrend felett aratott győzelem első, naiv-ártatlan, öntudatlanul gyermeki jele. A sors rendje a már mindig eleve bünbe esett természet. Az ártatlanul következetes jellemhez a boldog, mesebeli névtelenség, a szabadsághoz a (titkos) név, a megismerő-megnevező-tapasztaló nyelv, míg a sors világához a szfinx talánya, az ezoterikus beavatottak számára megfejthető rejtjel, a mitikus szám tartozik hozzá eloldozhatatlanul: „Az, ami a zöld posztóra festett összes számjegyből nézi a játékost - a boldogság -, itt minden női testből a nemiség kimérájaként kacsingat rá: mint az ő esete. És ez nem más, mint a számjegy, mint a rejtjel, amelyben éppen e pillanatban lesz nevén nevezve a boldogság, a szerencse, hogy aztán rögtön egy másik rejtjelbe ugorjon át." ${ }^{\text {63 }}$ Benjamin a szerencsejátékosban és a kurvában nevezi meg itt a két archetípust, amelyek a sorstól való öröm kicsikarásának alapattitüdjeiként értékelhetőek persze az ellenkező pólusokról. Nem övék a szám birodalma, hanem inkább a szám uralja őket (természetesen kapitalista értelemben is). A szám-kombinációk által meghatározott sorssal szemben áll a numerikusan értelmezhetetlen név. „Ez a magában való szent, józan, sorstalan - a név - nem ismer nagyobb ellenfelet, mint a sorsot, amely a kurválkodásban elfoglalja posztját, és a babonában megteremti magának arzenálját. A játékosban és a szajhában ezért van ott a babona, ami a sors alakzatait állítja fel, és ami minden parázna szórakozást sors-eszelősséggel és sorsot vágyó kéjsóvárgással tölt el, és még az örömöt is a sors trónja elé alázza." ${ }^{\circ 4}$

\footnotetext{
${ }^{63}$ Idem, 220.
}

${ }^{64}$ Ibidem. 
A sors által megbabonázott is elveszíti „,nevét”, hogy (névtelen) tömegként egy típust és egy tipikus öröm-elvet teljesítsen be, azonban a kurva és a játékos mellett (és gyakran velük együtt, egy „személyben”) ott a harmadik, a Benjamin által nem említett, sorstól sújtott archetípus, a nevétől megfosztott, sorszámmal ellátott alak, a fegyenc, az elítélt archetípusa. Ezeket a sors-archetípusokat a jellemtípusoktól éppen az individuális jellemzők hiánya, az uniformitás különbözteti meg. A névtől való megfosztottság egészen a fiziognómiai megkülönböztető jegyek elvesztéséig terjed: az egyenlőség eszméjének sajátosan fonák manifesztációját teremtve meg. Túl és innen jogon és társadalmon. Közvetlenül erről, közvetetten pedig az elbeszélés-emlékezés nehézségeiről is informál a vonattal „haza”-felé tartó Köves Gyuri első interakciója magyar nyelvü táboron kívüliekkel: „Kiszálltam egy városban, ahol a cseh szó mellett már magyart is sokat hallottam, s amíg az ígért esti csatlakozást vártuk, az állomás környékén asszonyok, öregek, férfiak, különféle emberek gyültek körénk. Érdeklődtek: koncentrációs táborból jövünk-e, és sokunkat faggattak, így engem is, nem találkoztam-e ott véletlenül hozzátartozójukkal, bizonyos ilyen vagy olyan nevü emberrel. Mondtam nékik, hogy koncentrációs táborokban általában nincs igen nevük az embereknek. Akkor meg iparkodtak külsejüket, arcukat, hajuk színét, jellemző vonásaikat leírni, s próbáltam megértetni vélük: hiábavaló, hisz koncentrációs táborokban többnyire igen megváltoznak az emberek." (Sorstalanság, 306.) Korábban kapunk arra nézve közlést, hogy ez a változás konvergáló jellegü, amennyiben a rabok egyéni vonásaikat vesztve egyre inkább egymásra kezdenek hasonlítani: vagyis ha a munka szabaddá, a munkakörülmények egyenlővé teszik a táborlakókat, akkor a neve-vesztett sorszámuk pedig fegyencruhaként szabja rájuk test-véri (uniform) sorsukat. Később, a Sorstalanság emlékező-elbeszélőjének és főszereplőjének időt kifeszítő gesztusában, mellyel a „,normális” „polgári” viszonyok hívogató ölébe visszatérve elutasítja azt a lehetőséget, azt a csábítást, hogy „,pusztán csak ártatlan” (331) legyen: ebben benne van az a mozzanat, mely 
a sorsot, valamint a hozzá tartozó fegyenc-létet és sorszámot a tapasztalás révén a szabadságba, a névbe integrálja - és az elöbbiek korábban korlátlannak mutatkozó hatalmát épp eme integráció folytatása, a kitartó rekonstrukciós és konstrukciós (képzeleti) munkát követelő emlékezés révén függeszti fel. Ebben a mozzanatban (a folytathatatlan élet folytatásaként: a könyv gerincén) sejlik fel a főhős neve mögötti rejtjeles írásként az íróé.

Az emlékező-elbeszélő alapattitüdjét azonban az emlékezés parancsával összhangban egy másik, nem pusztán technikai megoldások révén létrejövő eredő is meghatározza - részben ez magyarázza azokat a közlésmozzanatokat, amelyek az idézőjeles, riportszerü tudósításokat adják egy-egy kiemelt figura nyelvhasználatáról, valamint azokat a lírai stilisztikai kidomborodásokat is, melyeket hiába tulajdonítanánk akár egy koraérett kamaszkorú fiú elbeszélőnek. A szerző, az elbeszélő, valamint a figurák nyelvhasználatának peremvidékein létrejövő nyelv az, amelyet Pier Paolo Pasolini terminológiája nyomán nem grammatikai értelemben vett (tehát nem pusztán technikai, hanem tartalmi-formai jelentőségű) szabad függő beszédnek nevezhetnénk. Az én-elbeszélés szabad függő beszédű formájának (vagyis a lírai, epikai és drámai jegyek prózai józanságú egybeformálásának) prototípusa Dante Isteni színjátéka. E formával való analógiája magyarázza a Sorstalanság elbeszélőjének látszólagos szenvtelenségét, távolságtartását, nem pedig egy jó előre fejben tartott sztoikus filozófiai program. A holtak birodalmába ezúttal az emlékezet és képzelet rekonstrukciós és konstrukciós munkája révén tesz látogatást a szerzőből emlékezőelbeszélővé és főszereplővé, tehát tanúságtevővé is változó alak. Pasolini ezt a magatartást Dante kapcsán „kiegyensúlyozott távolságtartásnak” nevezi. Ez nem jelent filozófiai értekezéstől megkövetelhető elfogulatlanságot - hiszen akkor hiányozna a drámai szituáció, a személyes jelenlét, a tanúságtétel alakzata. De nem jelent „tudományos” érzelemmentességet sem, vagy a szenvedély hiányát, amely érzelem-mentességnek túlságos jelenlétét a Sorstalanság néhány olvasója, talán valami tudattalan vulgár-romantikus 
esztétikai kánon jegyében (amely ezt az „érzelmességet” az úgynevezett „,ágerirodalomtól” és „holokauszt-filmektől” egyértelmüen, kérlelhetetlenül elvárja), szinte számon kérni látszott az elbeszélésmód kapcsán. Ellenkezőleg: ez a forma, a „kiegyensúlyozott távolságtartás” szavatolja az érzések józan tisztaságát. Pasolini Dante költői szándékáról írott mondatait egy lényeges különbséggel érvényesnek gondolom Kertész Imre írói „szándékára” is:

„De a kiegyensúlyozott távolságtartás vastörvénye nemcsak oda vezet, hogy - egy olyan általános tervrajzon belül, amely nem teszi lehetővé a bizonyos érzelmi szabadságon alapuló részleges improvizációt - Dante erkölcsi és érzelmi magatartása hősei és az általa elbeszélt tények tekintetében mindig változatlan, hanem oda is vezet, hogy Dante önmagával szemben, illetve saját érzéseivel szemben is - legyen szó bár ádáz pörlekedésről, türtőztetett szánalomról, ártatlanul őszinte részvétröl, a létezés apró mozaikkockáinak egyszerre komor és óhatatlanul gyöngéd visszaidézéséről - kiegyensúlyozott távolságot tart fenn.

Mindezt úgy tudta elérni, hogy belegyúrta az anyagba, azaz saját költeménye hősévé tette önmagát.

Ezért az érzelmek sohasem az ő saját, hanem a költeményben szereplő Dante érzelmei: az egyes szám első személyben elhangzó $>>A j$, Pisa $<<$ kezdetü kirohanás például a látszattal ellentétben nem a szerző-Dantétól származik, hanem a hős-Dante egyik >>szabad függő beszéde $<<$.

Innen hát abszolút stilisztikai következetessége: az, hogy a költemény egészével szemben fönntartja a kiegyensúlyozott távolságot, attól a pillanattól kezdve, hogy mint szerző nyelvialkotóként részt vesz benne." 65

\footnotetext{
${ }^{65}$ Pier Paolo Pasolini: „Dante költői szándékáról.” Ford. Lukácsi Margit. In Pasolini: Eretnek empirizmus. Bp. Osiris, 2007. 145.
} 
A két mű között kétségtelenül fönnálló lényeges különbség pedig első látásra triviális: míg szerző és főhős azonos nevü az Isteni színjátékban, addig ez nem mondható el a Sorstalanságról. Ennek oka viszont kétségkívül az, hogy a név és a névváltás problémája a Sorstalanság alapproblémájának tekinthető. A név problémájáról már volt szó. A névváltás az önéletrajz klasszikus formájának lehetetlenségéhez kapcsolódik elsősorban. Mert a mű anyaga könnyen kínálná magát egy önéletrajzi formának. De ahogyan egy életrajzi anyag konstruktív tartalmi átformálását sem egyedül a még élők iránt esetleg érzett tapintat indokolja, úgy itt egyáltalán nincsen szó arról, hogy a szerző szemérmessége, félénksége vagy aggályoskodása indokolná azt, hogy önmagát megkettőzve (sőt megháromszorozva) én-főhősét álnévvel szerepeltesse. (Kertész Imre nyílt és aggálytalan közéleti megnyilvánulásai - tartalmuktól függetlenül - sem támasztják alá ezt a magyarázatot.) A névváltásnak tehát mélyebb formai-tartalmi oka kell hogy legyen. Fikció (képzelet) és valóság, élet és irodalom banális és filozófiailag végső soron tarthatatlan szembeállítása nemhogy nem lehet elegendő e probléma megragadásához, inkább álmegoldásaival elfedi azt. A Sorstalanság egyetlen valódi rokona a magyar irodalomtörténetben Móricz Zsigmond Árvácska címü könyve. Ahogyan utóbbiban az életrajz, úgy előbbiben az önéletrajz szolgáltatja - nem a tartalmat, hanem az anyagot. ${ }^{66} \mathrm{Az}$ (ön)életrajzi anyag és a tartalom-

\footnotetext{
${ }^{66}$ A K. dosszié lapjain Hafner Zoltán arra vonatkozó felvetésére reagálva, hogy a „Sorstalanságot mind a kritikusok, mind az olvasók >>önéletrajzi regénynek $<<$ szokták nevezni”, Kertész Imre válaszában részletesen is kitér erre a problémára: „Helytelenül [nevezik önéletrajzi regénynek], mert ilyen müfaj nem létezik. Vagy önéletrajz, vagy regény. Ha önéletrajz: akkor felidézed a múltadat, minél lelkiismeretesebben igyekszel ragaszkodni az emlékeidhez, rendkívül fontos számodra, hogy mindent úgy írj le, ahogyan az valóságosan is megtörtént, mint mondani szokás: hogy semmit se tegyél hozzá a tényekhez. A jó önéletrajz olyan, akár egy dokumentum: korrajz, amelyre $>>$ támaszkodni lehet $<<$. A regényben viszont nem a tények a fontosak, hanem egyedül az, amit a tényekhez hozzáteszel.” Itt igazából az lenne talán kérdéses, hogy olyan önéletrajz létezik-e, amelyet Kertész válaszában feltételez. De jóindulattal elfogadhatjuk ezt az önéletrajz ideálképének, amely felé a „jó” önéletrajz törekszik. Figyelemreméltóak azonban az önéletrajzi anyagból megformált regénnyel kapcsolatos megjegyzések a továbbiakban is. Mikor Hafner az előző mondatokra kicsit meglepődve (vagy meglepetést tettetve) úgy reagál, hogy tudomása szerint a regény „,teljes mértékben hiteles” és ,,a történet minden eleme dokumentumokon alapszik”, Kertésznek megadja az alkalmat, hogy tovább cizellálhassa ezt a különbséget: „Ez nem mond ellent a fikciónak. Sőt. [...] A [...] valóság-cserepek természetesen a fikció esetében is rendkívül fontosak. De a lényeges különbség mégiscsak az, hogy míg az önéletrajz valamire visszaemlékezik, a fikció megteremt valamilyen világot." Hozzátehetjük: ez az alternatíva kissé kimódolt, hiszen éppen a Sorstalanság esetében válik ragyogóan világossá, hogy az emlékezet és a müvészeti megformálás egymást erősítik. Később pontosítja is ezt a különbséget Kertész: „A regényben nekem kellett kitalálnom és létrehoznom Auschwitzot.
} 
forma viszonya analóg a két müben. A ,kiegyensúlyozott távolságtartás”, amely a müvek valódi morális tartalmának hitelét szavatolja, ha óhatatlanul eltérő technikai és stilisztikai megoldások révén is, de mindkét müben meghatározó elbeszélői alapattitüd. Móricz az Állami Árvácska névben magát a névtelenséget nevezi nevén. A névtelenséget már az „Első zsoltár” kezdő lapjain említi az elbeszélő: „,- Csöre. Csak így kiált neki, ez a neve a kis névtelennek, valahogy ez ragadt rá, Csöre! az állami árvára, Csöre!"67 Ez a névtelenség ellentmondásos, mert problémát hordoz: a mesehősök névtelenségével, mely névtelenség a mese lezárásakor távolba vesző (reményre utaló) boldogságuk („,míg meg nem haltak”, és: „itt a vége, fuss el véle!”) záloga, annyiban rokon, amennyiben a mü zárásában ez utóbbi névtelenség az elbeszélő megváltó „,szándéka” szerint az olvasótól áthidalhatatlan távolságra kerülő feloldozó halál záloga lesz. Az Árvácska figurájában azonban a legtöbb mesehőssel ellentétben már születésekor a reménytelenség reménye ölt kézzelfoghatóan alakot. Ez az állam (és az államot itt értsük egészen tizenkilencedik századi, reformkori módon, tehát halljuk bele a társadalmat is) révén eleve elrendelt sors már a névtelenségbe született: nincs név-emléke (a Csöre pusztán névnek látszik, de elementáris jelentésnélküliségével, az anyanyelv minimálisra redukált birtoklására való utalásával nyilvánvalóan nem lehet valódi mimézis alapja: a valódi mimézis majd az Állami Árvácska névre vonatkozik). Az Állami(-társadalmi) Árvácska névben és lényben, amennyiben a név a közösséggel való érintkezés minden vetületét meghatározza itt, az állam és társadalom szeretetre való képtelensége ölt alakot. (Az) Árvácska halála nem az államot és a társadalmat oldozza fel a mitikus áldozat jegyében, hanem magát (az) Árvácskát menti meg az állam és társadalom halálos öleléséböl. Bár a felületes látszat arra utal, hogy a közösség (a társadalom) szempontjából tekintve mitikus áldozatról van szó, az ártatlan (ez esetben a

Nem támaszkodhattam a külső, a regényen kívüli úgynevezett történelmi tényekre. Mindennek hermetikusan, a nyelv és a kompozíció varázslatával kellett létrejönnie.” Kertész Imre: K. dosszié. Szerkesztette Hafner Zoltán. Magvető, Budapest, 2006. 12-14.

${ }^{67}$ Móricz Zsigmond: „Árvácska.” In uő: Pillangó / Árvácska. Bp. Szépirodalmi, 1976. 212-3. 
gyermek) kiengesztelő haláláról, mégis, a mü nem is annyira rejtett intenciói szerint ez az áldozat a közösség felé nézve inkább tanúságtevő és egyben a közösség egészét vádló (sőt, a prózapoétikai tendencia szerint megsemmisítő-apokaliptikus) jellegü, a mártír szó eredeti (patetikus felhangoktól igen, de valódi pátosztól nem mentes) értelme szerint. A Sorstalanság főszereplője viszont már semmilyen értelemben sem áldozat; az áldozatként való beállítás ellen (a korlátolt polgári reflexet mai napig megbotránkoztató módon) nemhiába tiltakozik Köves a Steiner és Fleischmann bácsikkal való lezáró közvetített dialógusban és reflexióiban. Ironikusan még röstelkedik is ezért a tiltakozásért: hiszen úgy volna „teljes a története”, úgy nem volna benne hiba, ha valóban áldozat volna: „Az egyetlen folt, mondhatnám szépséghiba, az egyetlen esetlegesség, amit netán a szememre vethetnek, az, hogy most itt beszélgethetünk - de hát erről nem én tehetek.” (Sorstalanság, 330.) Az egyszerünek ható, azonban rendkívüli konstrukciós lehetőségeket magában rejtő Köves György névben a teljes névvesztés emléke él elevenen. Ezért láthat el ez a név az Árvácskától eltérően kettős, főhősi és emlékező-elbeszélői szerepkört egyaránt. És csak egy ilyen név-alak, akinek puszta nevében is él önmaga elvesztésének (nyelvi) tudata, csak ez a szellem-lény lehet az emlékezés közvetítője, tiszta médiuma is egyben - amely közvetítés szellemi tisztasága a klasszikus önéletrajz nyelvileg problémátlanabbul önazonos énelbeszélőjétől megtagadtatott volna.

A holtak birodalmából az „életbe” visszatérő, főszereplő Köves Gyuri számára a „rendes”, „polgári”, „hétköznapi” világ egyetemes bornírtsága ellen megmarad az értelem, a világos emlékezés szavának a lehetősége. A mủ cezúrája, amelyen minden megfordul, az a pont, ahol az elbeszélő-emlékező kimondva ráébred erre a lehetőségre, adottságra. Ez pedig a már idézett, didaxis határát súroló monológ sors és szabadság viszonyáról, amely a két szférát magától értetődő, de mintegy a beszélőt magát is meglepő pontossággal különíti el 
egymástól. De nem puszta tantétel-deklarációról van szó; a forma megmutatja ezt. Ugyanis ebben az esetben a kimondás szituációjának is mélyebb formai és nem pusztán technikai funkciója van: a kimondással egyidejü a ki-nem-mondás, a kimondhatatlanság, a közlésfunkció csődjének megállapítása is: hiszen a hallgatóság, az öreg Steiner és Fleischmann bácsi (akik, mint tudjuk, ott „,vannak mindenütt”) nem érti, és a saját világából nem is értheti a sors és a szabadság elkülönítését és kölcsönviszonyát, így a főszereplő felismerése a regény világán belül pusztába kiáltott szó marad. Főszereplő, emlékezőelbeszélő és szerző egy villanásnyi, időt kimerevítő pillanatban itt eggyé válnak. A tragikus iróniához hasonló erő munkál ebben a kölcsönös értetlenségben; a főszereplő szavainak performatív (többértelmủen fordított) hatása Kasszandra alakját idézi. A cezúra maga az értetlenség, a nyelv közlésfunkciójának termékeny csődje. A szerző, az emlékező-elbeszélő és a főszereplő közelsége a tragikus iróniához képest azonban intenzívebb személyességet teremt, miközben magának a személyességnek a kérdését is a végsőkig feszíti. Ennek az önmagát felemésztő személyességnek (nagyrészt a „,kiegyensúlyozott távolságtartás” attitüdjével jellemezhető) külsődleges hatását legpontosabban a metafizikai humor kategóriájával írhatjuk le. A számszerüsített fegyenclét integrációja a nevét „visszakapó” személyességbe ebben a törésben jelentkezik, ezzel a cezúrával indul meg: a regény élete itt kezdődik. A fegyencléttel megtört személy, a sorszámozható név: kikiáltják igényüket az elés felismerésre. A huszadik századi történelem adta a legvilágosabb leckét arra nézvést, hogy a sorszámozhatóság egyetemessé tehető, hogy minden egyes személy potenciális fegyenc. „Mindannyian veszélyben vagyunk”, mondta Pier Paolo Pasolini 1975. szeptember 1-jei, meggyilkolásának éjjelét megelőző utolsó interjúja során. Tételesen így volna kikerekíthető a regény végszava, mely valójában, ami a tartalmi esszenciát illeti, az első szó. Legjellemzőbb külső jegye e szónak a közlésfunkció csődje, az értetlenség (a logosz elvesztése): a nyelvcezúra. A forma e cezúra, valamint a lezáró retorikus feltételes mondat 
révén, mely a felejtés kísértésével kacérkodik, és amely előtt közvetlenül a szerző, elbeszélő és főszereplő újra szétválnak, nyitva hagyja, sőt kiélezi azt a problémát, hogy a regény világán kívül mi történik ezzel a szóval. A szerző, miután bátorítólag megszorította, újra elengedi főhőse-elbeszélője kezét.

$$
* * *
$$

A szereplő Köves Gyuri lépés-metaforája, szemben Steiner bácsiék szavajárásával: ,jött ez, jött az, jött amaz”, a két szféra időszemléletének összeegyeztethetetlenségét mutatja meg. „A két öreg meg ezalatt elmondta: >>bizony, itthon sem volt könnyü $<<$. Elbeszélésükből egészében valami kusza, zavaros és követhetetlen esemény benyomását, ködös körvonalait nyertem, amit lényegében nem nagyon láthattam, érthettem. Inkább csak egy szó gyakori, már-már fárasztóan sürü ismétlődését vettem a mondókájukban észre, mellyel minden újabb fordulót, változást, mozzanatot jelöltek: így például >>jött $<<\mathrm{a}$ csillagos ház, >>jött $<<$ október tizenötödike, $>>$ jöttek $<<$ a nyilasok, $>>$ jött $<<$ a gettó, $>>$ jött $<<$ a Duna-part, $>>$ jött $<<$ a felszabadulás. No meg a szokott hibát: mintha ez az egész elmosódó, valósággal elképzelhetetlennek tetsző és részleteiben - ahogy néztem - immár őnékik maguknak is teljességgel visszaállithatatlan esemény nem is a percek, órák, napok, hetek és hónapok rendes medrében, hanem úgyszólván mind egyszerre, valahogy egyetlen kavargásban, szédületben, mondjuk egy amolyan furcsa, váratlanul duhajra fordult délutáni összejövetelen esett volna például meg, mikor a sok résztvevő - hogy, hogy nem hirtelenjében mind eszét veszti, és végül már azt se tudja tán, mit is csinál.” (Sorstalanság, 324-5., kiem. tőlem.) A karneváli kép megint csak a mitikus gondolkodásra utal, amely a sors rendjének csak alkalmankénti felfüggesztését ismeri (az ünnepben és az áldozatban). A sorsából kitekinteni képtelen ember időszemléletét és homályos emlékezetét jellemzik azok 
a mozzanatok, melyek az események sorát kibogozhatatlan komplikációként, csak az ezoterikus beavatottak (az események aktuális lezárásától függően: a jósok, bölcsek, jövendőmondók; a költők, a zseniális politikai vezetők, a historizmus történetírói, stb.) számára értelmezhetőként való bemutatását szolgálják. Valamint arra a folyamatra is utal az idegenkedő viszony, amellyel Köves Gyuri Steiner bácsiék beszámolóját fogadja, ahogyan egyáltalán a múlt mint olyan létrejön a sors rendjében; még pontosabban arra, ahogyan ez a rend uralja a múltat, és sziklaként (ez a Steiner bácsi nevében is fellelhető kő szimbólumának sajátos értelme is lehetne) elállja az utat a megértés elől.

És nem pusztán a megértés, hanem a megváltás elől is. Ez a sorsképzet által uralt idő-, történelem- és életszemlélet ciklikus és teleologikus; télosza hozzáférhetetlen felsőbb erők által meghatározott, körkörössége hiábavaló végtelenség. A jogfenntartó erőhatalom fokozatosan gyengíti az őt létrehívó jogteremtő erőhatalmat, egészen addig, míg egy új, erősebb jogteremtő erőhatalom azt el nem törli, és a folyamat kezdődik elölről az egyéni életek, „,sorsok” iránt tökéletesen érzéketlenül. A télosz, a „haladás”, a végzet feltartóztathatatlanul jön és jön egyre közelebb a tehetetlenül és/vagy felelötlenül, sorsában döntésre képtelenül tengődő emberhez. Persze ez sematizmus, de létező, aktív, egészen közkeletü történelem-, politika- és életszemléleti sematizmus. A kortárs közéleti eseményeket befogadó (és azokat még csak véletlenül sem vagy pusztán látszólag alakító) egyszeri (magyar? kelet-közép-európai?) állampolgár legevidensebb, legkiirthatatlanabb ismeretszerzési rutinjának sematikus kerete.

Walter Benjamin Sors és jellem címü, 1921-ben megjelent, a sorsfogalom megképzése szempontjából irányadó írásában a következőképpen foglalja össze a sors időbeli összefüggéseit és ennek az összefüggésnek az élő emberhez való viszonyát: „A sors tehát abban mutatkozik meg, ha egy életet úgy tekintünk, mint elítéltetést; alapjában olyan élet ez, 
amelyet előbb ítéltek el, s csak aztán lett vétkes. Goethe e két fázist így foglalja össze: >>Bünös a szegény tőletek lesz $<<$. A jog nem büntetésre ítél, hanem bűnre. A sors az élők bün-összefüggése. Ez az összefüggés megfelel az élő ember természetes állapotának, ennek az egyelőre még maradéktalanul fel nem oldott látszatnak. Az ember eltávolodik annyira e látszattól, hogy soha nem merülhet teljesen bele, [de] önmaga legjava része uralma alatt láthatatlan marad. Alapjában tehát nem az ember az, akinek sorsa van, a sors szubjektuma meghatározhatatlan. A bíró ott pillant meg sorsot, ahol akar; minden büntetés keretében kénytelen - vaktában! ${ }^{68}$ - sorsot diktálni ő is. Ez sosem az embert találja, de a puszta életet benne igen, mely a látszatnál fogva részese a természeti bünnek s a szerencsétlenségnek. Sorsszerüen keríthető el az eleven élet így kártyának és planétáknak egyképp, és a bölcs asszony igen egyszerü technikával dolgozik: az életet csaknem-kiszámítható, csaknem biztos dolgokkal (a bizonyosság által szemérmetlenül teherbe ejtett dolgokkal) állítja bünösszefüggésbe. Így tud meg jelek képében valamit az emberben levő természetes életről, amelyet aztán a megnevezett fö helyébe helyezne; míg másfelől az ember, aki hozzá fordul, bünbe esett élete miatt számot ad magában. A bün-összefüggés egészen természetellenesen időbeli, jellege és mértéke merőben különbözik a megváltás vagy a zene vagy az igazság idejétől. A sors-idő sajátos jellegének rögzítéséhez kötődik e dolgok teljes átvilágítódása. A kártyavető és a tenyérjós persze azt tanítja, hogy ezt az időt bármikor egy másikkal egyidejűvé (nem jelenbelivé) lehet tenni. Önállótlan idő ez, amely parazita-mód utalódik egy magasabb rendü, kevésbé természetszerü életre. Nincs jelene, mert sors-szerü pillanatok csak a rossz regényekben vannak, és a múltnak s jövőnek is csak sajátos változatait ismeri." 99

\footnotetext{
${ }^{68}$ Kierkegaard írja le egy szemléletes képpel, hogy a sors olyan, mint a vak ember járása, hiszen az is egyszerre szükségszerü és esetleges.

69 Walter Benjamin: „Sors és jellem”. Ford. Tandori Dezső. In Walter Benjamin: i.m. 57-67. (63-4).
} 
A modern büntetés-végrehajtás történetében a börtön evidenciajellegének gazdasági faktora éppen az a redukált időbeli összefüggés, amely szerint a büntetését töltő elítélt börtönbeli időfelhalmozása pontos mennyiségi cserevonatkozásba állítható bünének büntetőjogi súlyosságával. Az eszmei kapitalista elképzelés szerint ezzel az időfelhalmozással (időelvonással) az elítélt rendezi tartozását az általa így vagy úgy megkárosított társadalom felé. Világosan mutatja ezt az összefüggést az a kortárs magyar jogrendben is jelenlévő gyakorlat, mely szerint a szabálysértés miatt kirótt pénzbírság összegszerủen lefordítható és átváltható fogházban letöltendő szabadságvesztéssé, tehát időtartammá. Az idő pénz? A szabadságvesztés formája „lehetővé teszi a büntetés mennyiségi kifejezését a változó idő által. Van a börtönnek egy fizetségoldala is, ebből ered gazdasági $>>$ evidenciája $<<$ az ipari társadalmakban, ahol így jóvátételként jelenhet meg. [...] A börtön olyan formán $>>$ természetes $<<$, ahogyan $>>$ természetes $<<$ társadalmunkban idővel mérni a csereforgalmat.” (Foucault, i. m., 317.) És nem csak a csereforgalmat, hanem a munkafolyamatot is. Köves Gyuri „természetesen” módosítószavának ironikus eredete ebben a redukált időbeli összefüggésben is keresendő. Werner Hamacher Anaximandrosz mondásának értelmezése során részletekbe menően elemzi a mitikus idő és a váltógazdaság ősi összefüggéseit (és ezzel implicit módon elő is rajzolja ezen összefüggések állhatatosságát) Büntörténet. Benjamin vázlata: „, A kapitalizmus mint vallás” címü tanulmányának bevezető oldalain. „Anaximandrosz töredékében az idő — pontosabban: az idő taxisza, vagyis az időtételezés — bünössé válásként és a megfizetés [Vergeltung] rendjeként van elgondolva. Ez az ökonómia ideje, abban az értelemben, hogy ez a törvény ideje — mégpedig egy minden létezőre érvényes törvény, taxisz, előírás, felépítmény és elrendelés ideje —, amely szerint az elkerülhetetlen eladósodást vagy bünössé válást a vele egyenértékű, ugyanúgy elkerülhetetlen jóvátétellel törlesztik. A szigorú összefüggést bűn és jóvátétel között elvi egyenértéküségük biztosítja. Ennek megfelelően az idő itt a keletkezés 
és elmúlás kettős folyamataként van elgondolva, amelyben a keletkezést az elmúlás, az időt tehát maga az idő törli el." Valamint, részben a német és az ógörög nyelvben előálló szemantikai szórásnak köszönhetően is, még evidensebbé teszi Hamacher „bün” és adósság (németül egyként: Schuld, ógörögül: aition: ok és bűn) azonosíthatóságát az etikai, jogi és gazdasági szféra „,váltógazdálkodásában”: „Mivel az idő e taxológiai rendje a természet és az ember világának minden területét kivétel nélkül a helyettesítés törvényének rendeli alá, ezért benne az etikai, a jogi és a gazdasági fogalmak helyettesíthetik egymást. Az igazságosság etikai dimenziója, amely az idő rendjeként van körülírva, a jogi dimenzióval fonódik össze a normák tekintetében, és mindketten a >>váltógazdálkodás $<<$ [Wechselwirtschaft] kalkulusa szerint határozzák meg magukat >>a természet állandó háztartásában<<. Az idő etikájáról tehát csak azért lehet szó, mert ez a jogivá alakított és ökonomizált etika már előzetesen az átváltás, a csere sémájához, az adósság/bün és megfizetés egyenértéküségéhez tartozik. Anaximandrosz mondásában a történelem ideje, az etikai idő ökonómiai időként, a bünössé válás és a vezeklés normatív idejeként értelmeződik. Azáltal, hogy valami belép az idő taxiszába, már adós [schuldig], és egyedül csak eltünése által szabadulhat meg adósságától [ent-schulden]. Az idő Anaximandrosz tézise szerint az eladósodás/bünössé válás és a megfizetés sémája; a jogtalanság, amelyet az idő előrehaladtával követnek el, hasonlóan következik be, mint a jogtalanság orvoslása: minden szabadság nélkül. Ezért ez az idő egy bűn- és megfizetés-kontinuum ideje, amely örök visszatérésben szakadatlanul tovább folytatódik; de nem a történelem ideje.”70

Nem a történelem ideje, mert a történelmi szabadság lehetősége nem merül fel ebben a mitikustól alig elváló időképzetben. A sors időszemlélete azonban vámpirikus viszonyban van a szellemi-történelmi (és nem a puszta természeti-fenomenológiai) élet idejével is:

\footnotetext{
${ }^{70}$ Werner Hamacher: „Büntörténet. Benjamin vázlata: >>A kapitalizmus mint vallás<<”. Ford. Pál Katalin. In etal.hu kritkai elmélet online. http://etal.hu/wp-content/uploads/downloads/2013/09/hamacher-buntortenet.pdf
} 
annak vérét szívja, szívének lüktetését megállítja. Mert az élet legmeghatározóbb, legfájdalmasabb és legboldogabb vagy épp legszégyenteljesebb, a halálhoz legközelebb kerülő eseményeiből (,a bizonyosság által szemérmetlenül teherbe ejtett dolgokból”) él; jobban mondva azokon élősködik. Ezt az összefüggést a Sorstalanság lezáró fejezetbeli dialógusának kezdetén egy gesztus metaforikus képe is szemlélteti: „Rövid idő múlva egy kéz - azt hiszem, tán a Steiner bácsié - emelkedett lassan a magasba, kelt útra, majd telepedett rá, akár egy óvatos, öreg denevér, a karomra." (Sorstalanság, 322-3.) A denevér képzete nemcsak mitikus vámpírtermészetével, hanem alkonyi és hajnali aktivitásával, a homályzónában aktivizálódó, szintén a mitikusra utaló életidejével, valamint az ezekben az időszakokban megfigyelhető ide-oda cikázásával, értelmetlennek tủnő hirtelen és esetleges irányváltoztatásaival is jelentést hordoz. Nemsokára megismétlődik a kép, mégpedig sokatmondóan a jövőre vonatkozó kérdés elhangzása és a felejtésre való felszólitás között. Itt már biztosan tudjuk, hogy Steiner bácsi keze az. S a grammatikai szerkezetből egy pillanatra úgy tủnik, mintha maga a denevér beszélne aztán, és mi másra is hivatkozna ő, mint az életre, a „szabad”, az „új” életre: „Fleischmann bácsi egyszerre ezt a kérdést intézte hozzám: - És a jövőre nézve mik a terveid? - Meglepődtem kissé, s mondtam neki: erre nemigen gondoltam még. Akkor a másik öreg is megmozdult, és felém hajolt a székén. A denevér is fölemelkedett megint, s a karom helyett ezúttal a térdemre ereszkedett rá. Mindenekelőtt is - így szólt - el kell felejtened a borzalmakat. - Kérdeztem egyre meglepettebben: - Miért? - Azért - válaszolta ö -, hogy élni tudjál -, s Fleischmann bácsi bólintott, és hozzátette: - Szabadon élni -, amire meg a másik öreg bólintott, és tette hozzá: - Ilyen teherrel nem kezdhetünk új életet -, s ebben némelyest igaza is volt, elismertem. Csak hát nem egész értettem, mint kívánhatnak olyat, ami lehetetlen, s meg is jegyeztem, hogy ami megtörtént, az megtörtént, $\mathrm{s}$ hogy végre is nem parancsolhatok az emlékezetemnek.” (325-6.) A „denevér” megszólal: ő szólít fel a feledésre. A 
bűnre/adósságra ítélt sors számára „szabadság” csak a feledésben van. A tragédia ebben az összefüggésben is a mítosz kritikájának bizonyul: Oidipuszon saját „felejtése” teljesíti be a végzetet. A felejtést, a szabadság torz-atavisztikus formáját, valamint a denevért egy konstellációba állító képen belül nyer értelmet az állat látszólag céltalan repkedése és lebegése: az emlékezés terhétől megszabaduló élet kesze-kusza és zavaros bár, de felelőtlenségében a súlymentesítettség illúzióját hordozza, a holtakból képződő szellemiérzelmi-fizikai talajtól látszólag eloldozottá, az emberi élet gravitációja alól démonikus módon felmentetté válik. Ez a „denevér”-egzisztencia kísértése, melyben az elfogulatlan gondolkodás esélyeit jól szemlélteti az az ismétlődő gesztus, ahogyan a két öreg komikusan egymásra bólogatva erősítgeti meg egymást a felejtés szükségességéről. A feledésre csak „kollektíven”, ügybuzgó egyetértésben lehet felszólítani. És nem pusztán a regényben technikai szempontból uralkodó ironikus közvetítés magyarázza azt, hogy a könyv utolsó, látszólag odavetett tőmondata a felejtés lehetőségére vonatkozik, hanem ezzel együtt a kísértés elleni mementó szükségessége is. Hiszen a zárómondatban feltételes módban megfogalmazott hozzáállásnak cáfolata, antitézise maga a könyv.

Azonban a felejtésnek is megvan a maga dialektikája, és itt nemcsak Nietzschére kell gondolnunk, hanem a könyv utolsó lapjait is több aspektusból kell átgondolnunk. A könyv értelmezői közül leginkább Vári György mutatkozott érzékenynek arra a paradox dinamikára, amelyet az emlékezés parancsa és a felejtés elkerülhetetlensége rajzol ki a mü egészében $^{71}$. Rudolf Bultmann gondolatainak, (jórészt Walter Benjaminéra rímelő) historizmus-kritikájának megidézése plauzibilis és szemléletes is (bár hogy ki miben hisz, azt kívülről megmondani kicsit bajosnak tünik, de fogadjuk jóindulatúan a kissé szerencsétlen kifejezést ezúttal): „Bultmann nem hisz, ahogy Kertész sem, a teodícea tradíciójából kinövő történetfilozófiában, amely immanens, történelmen belüli teloszt

\footnotetext{
${ }^{71}$ Vári György: „A történelem angyala. Sorstalanság”. In uő: Kertész Imre. Buchenwald fölött az ég. Bp. Kijárat Kiadó, 2003. 9-85.
} 
vizionál a történelmi folyamatban, ezért azt mondja [Bultmann és Kertész, ha jól értem L.Z.], hogy igazi létünket minden aktuális jelen pillanatban nekünk kell megtalálnunk, nekünk kell $>>$ felébresztenünk $<<$ a minden $>>$ történelmi pillanatban ott szunnyadó eszkatológiai pillanatot $<\ll 72$ - idézi Bultmann gondolatait részben szó szerint is Vári György. De nemcsak az úgynevezett továbbéléshez, a „folytathatatlan élet” folytatásához van szükség a felejtésre, hanem az emlékezet müködéséhez is. Bár kétségkívül igaz, hogy a „továbbélés szükségszerüen hozza magával a hütlenséget, a hütlenséget a holtak szelleméhez, hiszen ők holtak, Köves pedig él, ami lehatárolja a szolidaritás lehetséges mértékét" ${ }^{73}$. A szolidaritás mértékét lehatárolja, de a törekvés irányát nem szabja meg a továbbélés. A felejtésre, az emlékekkel szembeni részleges hűtlenségre igazából leginkább éppen az emlékek integrálása miatt lehet szükség. Ahogy a minőségi ébrenlétnek szüksége van a jó alvásra, úgy az emlékezet minőségi müködésének is szüksége van a felejtés javarészt akaratlan mennyiségi szelekciójára. De ha a felejtés akaratlagos, ha a felejtésre felszólítanak, akkor már abban a pillanatban kényszeressé is válik, hiszen saját természetes folyamata ellen való, hogy akaratlagos legyen. Mint ahogy az eleven óvodás gyerek sem szeret ebéd után lefeküdni, ha kényszerítik, hiszen hátha közben történik valami fontos, aminek ő nélkülözhetetlen résztvevője kellene hogy legyen. És a kényszeres, felszólításra történő felejtéssel együtt kényszeressé, elfojtottá válik az emlékezet is. Mindenesetre Vári György végül pontosan mutat rá, hogy a zárómondat felejtést kilátásba helyező megjegyzése nem a koncentrációs táborok létére, hanem a koncentrációs táborok boldogságára vonatkozik ${ }^{74}$, tehát legalábbis nem az emlékek összessége ellen irányul.

Platón Államának ironikus-palinódikus Ér-mítoszában a Léthé völgyében folyó Amelész (a.m. feledékenység, figyelmetlenség) folyója az újjászületendőket könnyíti meg előző

\footnotetext{
72 Vári György, i.m., 80.

${ }^{73}$ Vári György, i.m., 83.

${ }^{74}$ ld. Vári György, i.m., 84.
} 
életük emlékeinek terhétől. Dante Komédiájában módosult értelemben korrigálja a vonatkozó mítoszt. Az alvilág folyóinak, az Akherónnak, a Styxnek, a Phlegethónnak, valamint a Dante képzeletében befagyott tóvá alakuló Kókütosznak a vize a földről lefolyó könnyekből táplálkozik. Jellegzetesen késő középkori szemlélet szerint még a gyülölet (Styx) is a szomorúságból, a földi melankóliából ered ilyenképpen (vö. Pokol, XIV. 94-120; XXXIII. 91-157). A görög mitológiában az ötödik alvilági folyó a Léthé, azonban ez Dante látomásában máshonnan ered, és máshol is folyik, mint az előző négy: míg azokat a Pokolban, emezt a Purgatóriumban találja meg a holtak birodalmában vándorló költő, és társat is ad mellé az Eunoé folyó képében. Míg a pokolbeli vizeket a földi könny táplálja, emezeket ugyanaz „az ős Szeretet és a fö Okosság”, melyet a Pokol kapujának felirata hirdet (Pokol, III. 6). Felejtés és emlékezet dinamikája is módosul ennek megfelelően, ahogyan azt a Purgatórium-beli két folyót őrző Matilda feltárja a költőnek és Vergiliusnak. A Léthé a folyó, amely a „bün emlékét törli” (,che toglie altrui memoria del peccato”), a költő által hozzáköltött Eunoé pedig ,ráemlékeztet a feledt erényre”:

E víz, melyet látsz, nem ered a földnek

eréből, mely kimerül, s mellyet újra

légi párák lecsapódása tölt meg:

hanem forrásból, egyformán ujúlva,

és biztosan, mert Isten tölt beléje,

amennyi víze kétfelé kihulla.

S titkos erőt ruház mindegyik érre:

egyik a bün emlékét törli, másik

ráemlékeztet a feledt erényre.

Itt ennek neve Léthe; túlra látszik 
Eunoé; - s aki nem issza vízét

mindkettőnek: üdv arra nem sugárzik. ${ }^{75}$

Tekinthetjük a bün vonatkozásában akár isteni adománynak is, ám a felejtés önmagában nem lehet cél: ez a különbség megmarad Steiner bácsi és Köves Gyuri hozzáállása, időtudata között. (Nemcsak a szereplők rokonságára, hanem az álláspontok eltérésének végső soron megszüntethetetlen jellegére utal az is a könyv világán belül, hogy a két szereplő az azonos jelentésủ névnek német, illetve magyar alakváltozatát viselik.) A felejtés önmagában nem lehet cél, de nélküle nem boldogul az emlékezet sem. Persze a felejtést célul önmagának kitüző szorongó időtudat valójában nem is igen tudja, mit akar. Nincs is nagyon mit akarni. Nem tudatos, inkább ösztönszerü, szorongó „céltételezés” ez. A sorsidőben a szükségszerüség és esetlegesség kategóriái rátelepednek az időaspektusokra, valamint ezek pszichológiai meghatározásaira; a sors-idő szemlélete felől a múlt a szükségszerüség, a jövő pedig az esetlegesség szférájába zuhan vissza, melynek révén az eltelt élet és történelem legmeghatározóbb eseményei feledésre ítélt jóvátehetetlenségekké, a remény és felelősség terhétől megszabadult elkövetkező élet kilátásai pedig értelmetlen tengődéssé válnak. Itt is észre kell vennünk azonban a sors-szemlélet ambivalenciáját, azt, hogy ebben a szemléletben a szükségszerüség és esetlegesség egysége révén előálló jelenségek külsődlegesen megítélve elválaszthatatlanok a szabadság aktusaitól: a múlt

\footnotetext{
${ }^{75}$ Dante Alighieri: Isteni szinjáték. Ford. Babits Mihály. Európa, 1974. 244.o. Purgatórium, XXVIII. 121132/133. „L'acqua che vedi non surge di vena / che ristori vapor che gel converta, / come fiume ch'acquista e perde lena; / ma esce di fontana salda e certa, / che tanto dal voler di Dio riprende, / quant' ella versa da due parti aperta. / Da questa parte con virtù discende / che toglie altrui memoria del peccato; / da l'altra d'ogne ben fatto la rende. / Quinci Letè; così da l'altro lato / Eünoè si chiama, e non adopra / se quinci e quindi pria non è gustato: / a tutti altri sapori esto è di sopra." http://www.filosofico.net/ladivinacommedia.htm
} 
vonatkozásában a jóvátehetetlenség valóban ugyanúgy óhatatlanul tételeződik, ahogyan a halottak számára a jövő is „reménytelen”.

Ennek a kilátástalan, potenciálisan minden jelenségen uralkodó szemléletnek az alternatívája, pontosabban a megsemmisítője valóban az eszkatologikus (a halálból, a halottak emlékezetéből kibomló), messianisztikus (a halottakért táplált remény jegyében az élőkért cselekvő) idő-, történelem- és életszemlélet. Ez a halottak néma kérése, követelése: az emlékezet nem a puszta dokumentációban, hanem a cselekvésben él. Minden egyes cselekvés pedig csak az adott szituációban él. Éppen ezért fontos, hogy ne engedjünk teret a döntő pillanatokban a hamis pátosznak vagy a „nagy” terveknek. Ne áltassuk magunkat: a lábunk alatti talajt nemcsak mitikus, nemcsak vallási, hanem a legprózaibb fizikai értelemben is a holtak alkotják. A cselekvés sem feltétlenül ,politikai” értelemben értendő: nem gondosan vagy gondatlanul kitervelt társadalmi utópiák kézi vezérlésü realizálására vonatkozik. Nagyon szegényes értelmezése ez a cselekvés szférájának. A nyelv tágas értelemben vett fogalmának érvénye szerint minden cselekvés nyelvi megnyilvánulás. A magánjellegü kapcsolatokban, valamint az emberi alkotás, közösségszervezés és kapcsolatteremtés „,nem-politikai” (pontosabban: a primer hatalomszerzési ambícióktól független) jellegü formáiban szabadabb tere nyílt eleddig a (bármilyen gyenge és eseti) megváltó jellegủ energiáknak. Persze amennyiben valóban megváltó jellegü egy ilyen megnyilvánulás, annyiban a terminus ideális értelmében politikai is. Ebben a látszólag mégoly korlátozott érvényü eszkatologikus-messianisztikus jegyben cselekvő és élő ember nem mond le a felelősségről, nem várja ki, hogy ,jöjjön” az utólag elkerülhetetlennek gondolt vagy előre kikerülhetetlennek jósolt esemény, vagy, jobban mondva, utólag és előre nem keres menekvést és kibúvót a maga számára abban a magyarázatban, hogy „de hát így történt, mit tehettem volna?”, hanem, ha teheti, elébe megy a történésnek, az úgynevezett 
nagybetűs történelemnek, és a tévedés kockázatát felelősséggel vállalva lép, dönt. (Ez legalábbis az etikai, vagyis az öntudat által uralható („kanti”) szférája létezésének.) Vagy, megint csak jobban mondva, utólag és előre is ekként tekint az eseményekre: nem csak úgy jöttek, hanem beléjük mentünk, mind, egyenként ki-ki lépett egyet. Aztán megint. A történelem ilyen lépéseknek a potenciálisan végtelen szövedéke. Ha pusztán úgy tekintünk a történelemre, a történetre, hogy az ,jött”, akkor sohasem szabadulunk a kilátástalan történelmi helyzetek körforgásából, és az úgynevezett győztesek, a mindig aktuálisan hatalmon lévők nézőpontjából alkotunk fogalmat a történelemről. Ez a történelemfogalom torz, és végső soron emberhez méltatlan. Még ha minden felfejthető jel, amely körbevesz bennünket, valamilyen torz-Ananké uralmára utal (mint Köves Gyuri esetében), akkor is érdemes, sőt akkor elengedhetetlen észben tartanunk, hogy ez az uralom látszólagos és felületi, ez az uralom olyan szférát próbál bitorolni, mely soha nem lehet (strukturális és, kockáztassuk meg kísérleti jelleggel a kifejezést, metafizikai okokból) az ő felségterülete. Érdemes, sőt elengedhetetlen ezt észben tartanunk, amennyiben meg akarunk őrizni vagy alkotni abból valamilyen (természetszerüleg nem humanista és nem univerzalisztikus, de: potenciálisan, esetről esetre általános érvényüvé váló) értéket még, amit az ember fogalma, pontosabban ideája jelölhet. Még ha a lépés az auschwitzi orvos felé visz közelebb, akkor is mi lépünk, egyenként, senki sem léphet helyettünk. Amikor 1940 szeptemberében a franciaspanyol határon, a tengerparton fekvő Portbou motelszobájában rejtőzve úgy dönt Walter Benjamin, hogy az őt üldöző Gestapo szorítása elől menekülve magához veszi a feltehetően arra az eshetőségre magánál tartott halálos adag morfiumot, ha reménytelennek látszik a menekülés, akkor ezt megint csak nem teheti meg helyette senki, és döntésének megítélését nem befolyásolhatja az a másnap előálló helyzet, hogy menekülő társainak mégis megadatott a határátkelés és így a szabadulás is, bármilyen vonzó (ám teljes mértékben felelőtlen) is lehetne ezúttal akár a sors úgynevezett iróniáján merengeni. Ha oly sokan 
mondják, hogy a koncentrációs táborok úgynevezett borzalma leírhatatlan, ábrázolhatatlan, akkor nincs más teendő Kertész Imre számára, aki szabálytalan módon „túléli” ezeket az úgynevezett borzalmakat, mint hogy megkísérelje az ábrázolást, a leírást, és a cselekedet (jelen esetben a mü megalkotása) révén vállalt felelősség teremti meg számára a tévedés és a tévesztés jogát. „Hacsak magam is el nem felejtem.”

A Sorstalanság címü könyvre nem véletlenül ezen a leginkább didaktikusnak tetsző ponton, a két öreg és Köves Gyuri kvázi-platóni dialógusánál leselkedik az a veszély, hogy kéretlen erkölcsi leckéztetésben részesíti olvasóját. Kertész Imre későbbi irodalmi és közéleti megnyilvánulásai is mind benne maradtak ebben a veszélyzónában, és nem is minden ilyen megnyilvánulás menekül meg ettől veszélytől. Az író ebben a legkritikusabb esetben sem kerülte el a veszélyt, hanem inkább szembegyalogolt vele: kétségkívül lehet egy redukált allegorézis mentén olvasni a lezárást közvetlenül megelőző közvetített dialógust úgy is, hogy az az úgynevezett többségi társadalomnak szóló, a szenvedésből merített erkölcsi fölény magasából előadott tanmese. Ám azon túl, hogy ez a redukált értelmezés az olvasót (és főként a magyar „többségi társadalmi” olvasó történelmileg jól megalapozott, habár nem tudatosított, társadalomlélektanilag motivált elfojtását, frusztrációját) minősítheti inkább, mintsem a művet, ebben az esetben még az a jóval fontosabb körülmény is a műalkotás megmentését idézi elő, amelyre már több ízben utaltam: a közvetített dialógus dramatikus szituációba való beágyazása, a megszólaló figurák eszköztelen ,pszichológiai motiválása” (vagyis a nem grammatikai értelemben vett szabad függő beszéd „kiegyensúlyozott távolságtartása”), valamint a közöttük kibontakozó, a kölcsönös megértést, tehát a közös nyelvet végső soron ellehetetlenítő kommunikációs helyzet (a csend, a kifejezés nélküli erő közbeszólása) mind olyan, részben az írói reflexiós technikán alapuló, ám azon (a könyv többi motívumával és elemével, valamint a 
történelemmel való kimeríthetetlen kapcsolódásai folytán) a tartalom-forma egésze felé túlmutató elemek, melyek együttes látása és észben tartása a fent vázolt és az irodalomtörténet-írás során egészen gyakran előforduló moralizáló allegorézist egy mozdulattal teszi végtelenül szomorúvá és megmosolyogtatóvá. És így voltaképpen az elkerülhetetlen didaxis-veszéllyel való nyílt, ám reflektált szembesülés - éppen a veszély forrása, a szituáció vállalása menti meg a müvet.

A szereplő/elbeszélő aspektusokat ezen a ponton már összevegyítő Köves Gyuri válasza az öreg Steinernek és Fleischmann bácsinak: „de hát nem egész úgy volt csak, hogy $>>$ jött $<<$ : mi is mentünk. Csak most látszik minden késznek, befejezettnek, megmásíthatatlannak, véglegesnek, ily roppant gyorsnak és ily rettentő homályosnak, úgy, hogy >>jött<<: most, így utólag csupán, ha hátrafelé, a visszájáról nézzük. No meg persze, ha elöre tudjuk a sorsot. Akkor, csakugyan, mindössze az idő múlását tarthatjuk számon. Egy ostoba csók például ugyanolyan szükségesség, mint, mondjuk, egy moccanatlan nap a vámházban vagy a gázkamrák. Csakhogy, akár hátra, akár előre nézünk, mindkettő hibás szemlélet - vélekedtem. Elvégre is húsz perc olykor, és önmagában véve is, meglehetős nagy idő. Minden perc elkezdődött, tartott, majd befejeződött, mielött a következő kezdődött volna ismét. Mármost - mondtam - vegyük csak fontolóra: mindegyik ilyen perc hozhatott volna tulajdonképp valami újat. Valójában nem hozott, természetesen - de hát azért el kell ismerni: hozhatott volna, végeredményben mindenikben történhetett volna valami más is, mint ami történetesen történt, Auschwitzban éppúgy, akárcsak, tegyük föl, itthon, mikor apámat búcsúztattuk.” (kiem. tőlem, 327-8) 
Természetesen. Az ehelyütt elhangzó „természetesen” már túlmutat a regény (nagyrészt technikai eszközök révén élő) iróniáján: bensőséges, a szomorúság legmélyebb völgyeit megjárt szeretetteljes zsidó humor munkál itt. 


\section{Epilógus/átmenet}

A Sorstalanság cím cseppet sem magától értetődő. Természetes, hogy a müvészi koncepció leglényegét érinti a cím, ám többszörös értelemben, melyek közül eleddig egy, a legfelforgatóbb, nagyrészt rejtve maradt a müben, és nem segítették elö fölbukkanását sem az író önértelmezési gesztusai, sem az értelmezések javarészt hasonló mederben folyó gondolatmenetei sem. „A koncentrációs táborok boldogsága” - ez a talán első hallásra pusztán provokatívnak tünő, a könyv nyelvén belül azonban kristályosan józannak bizonyuló megfogalmazás valódi értelmét csak a cím értelmezésével összefüggésben nyeri el: pozitív értelmében (nem eltekintve a szó morfológiájától, a fosztóképzős alaktól) nem más ez a sorstalanság, mint ez a „boldogság”: és nem mást mondhat ez nekünk ennek a felforgató könyvnek a világán és autonóm nyelvén belül, mint hogy Hölderlin sorstalan, boldog istenei a huszadik században a koncentrációs táborokban inkarnálódtak, ha valahol egyáltalán testet ölthettek. Mert a történelem tapasztalásának teljessége és értelme számukra volt adott, még ha feltehetőleg sokan közülük vakok is maradtak nagyrészt erre a tapasztalásra, vagy képtelenek voltak azt artikulálni, ami végső soron majdnem ugyanaz; mélyen érthető módon képtelenek voltak szellemileg integrálni tapasztalatuk lehetséges történelmi értelmét: az áldozatok is, nemcsak hóhéraik. Sőt talán ez a vakság és némaság is hozzátartozik a tapasztaláshoz. Itt természetszerüleg csakis sejtéseket fogalmaztam meg.

Ha azonban a könyv szerzőjének önértelmezéseiből indulunk ki, javarészt más kép rajzolódik ki a sors és a sorstalanság fogalmairól. A főként a Gályanaplóban található vonatkozó reflexiókban a sors legtöbbször a saját értelmét beteljesítő élet alakzataként, míg a sorstalanság üres determinizmusként, életidegen ,értelmet”, ,jelentést”, de elsősorban funkciót betöltő életimitációként értelmeződik. Az aforizmát, esszét és (mühely)napló(regény)t író Kertész Imrénél csak nagyon ritkán csillan fel a sors és 
sorstalanság értelmezésében annak a termékeny ambivalenciának a lehetősége, amely a Sorstalanság lapjain tárul fel: legnyíltabban a kvázi-platóni dialógusokban Köves Gyuri és az idősebb nővér, valamint a „haza”-térő Köves Gyuri és a két öreg között. A szerző, majdhogynem ezekkel az ábrázolásokkal szembemenve, még egy sorstalanság-definíciót is megfogalmaz a Gályanapló lapjain: „,ha a ránk kirótt determinációnkat éljük végig valóságként, a saját - viszonylagos - szabadságunkból következő szükségszerűség helyett, ezt nevezném sorstalanságnak." ${ }^{, 76}$ A dolgozat eddigi gondolatmenetétől tudatosan tartottam távol az ehhez hasonló szerzői önértelmező gesztusokat; a regény radikalitásához képest ugyanis e reflexiók jóval megszokottabb, majdhogynem „kultúrpesszimistának” nevezhető értelmezésre redukálják az ott feltáruló problémakomplexumot. Sőt a regényt az életmü egészétől, valamint a regény és az életmü recepciótörténetétől is igyekeztem távol tartani, mégpedig azért, mert mind a későbbi könyvek világát, mind a komolyan vehető recepciók javarészének megközelítéseit többé-kevésbé ezek az önértelmező gesztusok irányították. Akkor is igaz ez, ha némelyik értelmezés polemizál az önértelmezések megállapításaival: a vita menetét elsősorban nem maga a mü, hanem inkább a reflexiók különböző (óhatatlanul előálló) redukciói határozzák meg. Természetesen ilyen indítás felől is elképzelhető áttörés átfogóbb kritikai felismerés felé; egy ilyen áttörésre példát Vári György már idézett monográfiájában találhatunk, ahol, még ha bizonyos járulékos, intuitív jellegü megjegyzések talán támadhatóak is ${ }^{77}$, a Sorstalanság értelmezése során a szerző végső soron mégis csak példamutató következességgel mutatja ki emlékezés és felejtés aporetikus tendenciájú dialektikáját a könyv lezáró része kapcsán az értelmezés konklúziójaként.

Ugyanennek a könyvnek az utolsó fejezetéhez irányítom jó szívvel az olvasót, amennyiben

\footnotetext{
${ }^{76}$ Kertész Imre: Gályanapló. Magvető, 1999 (1992). 19.

${ }^{77}$ A felejtés jelentőségének felismerése sem igazolja például érzésem szerint Köves és Steiner bácsi lehetséges azonosításának feltételezését sem (Vári György, i.m., 84). De az ehhez hasonló kitételek számomra még bőven az invenciózus szertelenség kategóriáján belül maradnak, mely kategória valószínüleg jellemezheti jelen dolgozat egynéhány gondolatkísérletét is.
} 
a Sorstalanság recepciótörténetéhez keres fogódzókat ${ }^{78}$. A jelen dolgozatnak nem volt célja egy ilyen áttekintés, nem pusztán azért nem, mert még nem időszerü ezt a munkát újra elvégezni, hanem a talán már több ponton kifejtett problémakomplexumra való minél zavartalanabb koncentráció érdekében sem. A cél itt a sorsfogalom kritikai megközelítését elösegítő momentumok értelmezése volt.

Még az előző bekezdésben felvetett problémához egy kitérő erejéig visszatérve: „érdekes”, hogy azok a kétségkívül ritkábban előforduló önértelmező megjegyzések, amelyek a münek akár a szerző polgári énje feletti autonómiáját hangsúlyozzák, jóval kevesebb súllyal estek latba azoknál, mint amelyek egyfajta hiábavaló „tanulság” levonása felé vihették a mindenkori értelmezőt. Pedig mennyire más kép rajzolódik ki akár csak a következő sorokból is, melyek a Sorstalanság alkotáspszichológiai folyamatára utalnak a $K$. dosszié lapjain: „Fel kellett ismernem, hogy olykor fölkészületlenül érnek a kezem alól előbújó mondatok: többet tudnak, mint amennyit én tudok; titkokkal lepnek meg, amelyeket

\footnotetext{
${ }^{78}$ Vári György: „A Sorstalanság recepciótörténetéröl”. In uő: i.m., 200-229. Persze a monográfia megjelenése óta eltelt tíz év. Azóta két monográfia és egy úgynevezett „Kertész Imre-szótár” jelent meg. Molnár Sára könyvét már idéztem jegyzetben. Földényi F. László egy „Kertész Imre-szótárat” állított össze: Földényi F. László: „Az irodalom gyanúba keveredett”. Kertész Imre-szótár. Bp.: Magvető, 2007. A szerző a szócikkekben javarészt beleérzés-szerüen, asszociatív analógiák mentén, saját gondolkodásába integrálva „érti meg” Kertész Imrét. Kertész Imre életművét jellemző módon egy tömbként kezeli, problémamentes folytonosságot előfeltételezve a művek terminológiája, gondolkodásmódja, poétikai elve tekintetében. Minden egyértelművé válik a beleérző intuitív lendület számára, minden termékeny, dialektikus ambivalencia elveszíti feszültségét. Jellemző példa erre Földényi könyvéből a „sors” szócikk. A Sorstalanság című könyvből itt egyetlen árva hivatkozás sem található, annál inkább természetesen a Gályanaplóból, persze onnan is jellemzően azok a bejegyzések, amelyek a dolgokat mintegy „helyre rakják”. Így el is érkezik már a szócikk elején Földényi F. László sors és sorstalanság „,helyes értelmezéséhez”: „Kertész hajlik arra, hogy az itteni életet (s ezt ő maga előszeretettel kurziválja) redukált életnek lássa, olyasminek, amibe belevetettek minket - kiemelve bennünket valahonnan, egy másik, igazi életből. A sorsból. S ide, a sorstalanságba száműztek bennünket." Földényi F. László: i.m. 248-249. A mély értelmü, kvázi-gnosztikus „felismerések” burjánzásának valóságos táptalaja lehet egy-egy ilyen megfogalmazás, ám a kritikai megközelítés esélye természetesen nem teremtődhet meg ebben a beszédmódban. Arról nem is szólva, hogy az idézett megfogalmazásból az egyéni, vagyis az egyetlen valós felelősség kérdése teljességgel kiiktatódik: a sorsból, az ,,igazi életből” kiemelnek, a sorstalanságba, az ,itteni életbe" belevetnek, száműznek. Ki vagy kik? Másrészt teljességgel inadekvátnak tartom minden esetben azt a beszédmódot, amely azt sugallja, hogy az adott sorok írója tisztában lehet azzal, hogy mit gondol egy másik ember: legyen az Kertész Imre, vagy bárki más.
} 
nem ismerek; s nem türik beavatkozásomat, valami önálló, idegen életet élnek, amit inkább megértenem kellene, mintsem uralni..."79

A sors kritikája a művészet kritikáját is jelenti. E kritika első jelentős momentumait kétségkívül a romantikában fedezhetjük fel, egyáltalán, a kritika müvészi funkcióként való értelmezése is a (német) romantika öröksége. A Sorstalanság címü könyv höse viszont több rokon vonással kötődik a klasszikus jellemépítés hőséhez, mint a romantikuséhoz. De csak azért, mondhatnánk kicsit könnyelműen, hogy a mü a klasszikus hőst kiszabadítsa és elszabadítsa a sors fennhatósága alól. A Sorstalanság világa, és ebben is a már klasszikus művekkel rokon ez a könyv, önmagában megálló lezárt totalitás, a rend látszatára, harmóniára, illetve atonális jellegü összhangzatokra büvölt káosz.

Óhatatlanul más regiszterben és művészeti ágban, jellegzetesen megjátszott naiv-amerikai frivolitással, de a klasszikus jellemépítést forradalmasító alapvető logikáját illetően mégis meglepően hasonló dolgot művel Quentin Tarantino legutóbbi filmjében, a már címében is erre a (f)elszabadítási folyamatra utaló Django Unchained címü pszeudo-westernben, ahol a sztereotipikus fehér-gyarmatosító westernhős szerepét egy felszabadított fekete rabszolga vindikálja magának. A történelemfilozófiai különbségek mellett persze fennáll a két mủ között az az alapvető eltérés, hogy míg a Sorstalanság egy pillanatra sem akar klasszikus önéletrajznak látszani (a névváltás ezt evidenssé teszi), addig Tarantino filmje elbeszéléstechnikai szempontból (is) igyekszik betartani a műfaji film (a spagetti western) szabályait.

Mihail Bahtyin alkalmazza a klasszikus és a romantikus jellemépítés közötti megkülönböztetést már idézett, 1919 környékén keletkezett müvében. A klasszikus típusú jellemépítés alapja a „sors mint művészi érték” ${ }^{\text {" }}$. Bahtyin művészetfilozófiájában is sajátos terminusértéke van a sors fogalmának, melyet igyekszik is a szerző pontosan

\footnotetext{
${ }^{79}$ Kertész Imre: $K$. dosszié. 167.

${ }^{80}$ Mihail Bahtyin: A szerzö és a hös, 269.
} 
megkülönböztetni a vulgáris sorsfelfogástól. „A sors a személy létének mindenre kiterjedő meghatározottsága, azaz szükségszerüen determinálja a személy életének valamennyi eseményét.”81 De ez csak a művészi-esztétikai szférára érvényesíthető kategória: „A sors: annak a nyomnak a müvészi transzkripciója, melyet a belülről, a maga céljai által szabályozott élet hagy maga után a létben, a sors annak a lenyomatnak a művészi kifejeződése, melyet a belülről minden elemében értelmezett élet hagy maga után a létben. A létben hagyott lenyomat szintén saját logikával kell hogy rendelkezzék, de nem az élet célirányos logikájával, hanem tisztán müvészi logikával, mely a kép egységét és belső szükségszerüségét irányítja." 82 Egy ilyen müvészi logikát, melyben az események és tettek feltartóztathatatlanul haladnak a mü beteljesülése felé, technikai szempontból a sürü, következetes és zárt motívumszövés szolgálja leginkább, és ezek a motívumok mind a mü mint sors beteljesülésére utalnak. A Sorstalanságban ugyanolyan erősen felfedezhető az epikai motívumok mitikus vonatkozása, mint ahogyan azt Walter Benjamin mutatta ki Goethe Vonzások és választások címü regényében. A mübeli élet minden egyes, akár (vagy legfőképp) jelentéktelen reáliái hajlamosak jellé, a sors jelévé változni, persze jóval áttételesebb módon, mint a jövendőmondók jóslataiban, de a müvek mitikus-epikus rétegében tulajdonképpen a jóslással analóg menetü ez a folyamat: „,...a hagyományos szemlélet [der überlieferten Anschauung] szerint azonban a sors jelévé válhat a testi jelenségeken kívül a külvilág, az élet bármely mozzanata [alle Erscheinungen des äussern Lebens]. Jel és jelölt dolog összefüggése azonban mindkét szférában [a jellemében és a sorséban - LZ] egyképp zárt és nehezen megközelíthető, bonyolult problémát mutat, még ha e problémák eltérőek is, s ennek oka az, hogy - a jelek fölszínes megítélése és tévesen végrehajtott önállósítása ellenére - a két rendszerben a jellemet és a sorsot nem oksági összefüggések alapján jelenti a jel. Jelentésbeli összefüggés okságilag sosem indokolható,

\footnotetext{
${ }^{81}$ I. m., 270.

${ }^{82}$ Uo.
} 
még ha egy-egy esetben az adott jelek létezését sors és jellem okozza is." 83 És ahogy a Vonzások és választások esetében a betétnovellában, a Csodálatos szomszéd gyerekekben (jellegzetesen goethei módon elrejtve), úgy a Sorstalanságban a halál közeli tapasztalat műimmanens értelmezésében, a lezárást megelőző kvázi-platóni dialógusban, valamint a hős sajátos túlélésében, a túlélés puszta tényében (érthető ez a túlélés az életműben következő Kertész-könyv, A kudarcban szereplő Köves György betétregény-figurájára, de akár a szerzői-önértelmezői gesztusok ágensére is) mutatkozik meg a sors és a mitikus rend, valamint közvetettebb módon magának a sors jelrendszerének (mely, mint említettük, a könyv epikai rétegének jelrendszere is) a kritikája. A lírai és a drámai (megjelenítő) mozzanatokban. És ezen a ponton radikálisan meg is szakad a klasszikus jellemépítéssel való párhuzam is, pontosabban az eddigi klasszikus jellemépítésre utaló mozzanatok átértelmeződnek, megszüntetve őrződnek meg (természetesen a klasszikus jellemépítéssel való párhuzam az egész könyvben csak megszorításokkal engedhető meg). A klasszikusan felépülő jellem semmilyen értelemben nem lehet kezdeményező, semmilyen hóbortos „szabad akarati” tényező nem motiválhatja. Ez egészen a lezárásig érvényesíthető Köves Gyuri figurájára is. Hogy sorsa beteljesedjék, az is fontos, hogy a klasszikus hős életéről mint lezárt múltról alkothassunk képet: a klasszikus hősnek célszerü meghalnia. A Sorstalanság hőse túlél. De éppen ezért is tulajdonképpen már nem „hős”. Köves Gyuri ironikus mentegetőzésében reflektál is erre a hibára, amint már idéztem is: „Az egyetlen folt, mondhatnám szépséghiba, az egyetlen esetlegesség, amit netán a szememre vethetnek, az, hogy most itt beszélgethetünk - de hát erről nem én tehetek.” (Sorstalanság, 330.) A szépséghibánál pontosabb meghatározást itt nehéz is volna találni. Mert nemcsak a regény világán belül él túl, sőt valójában a regény világán kívülre, a müvészi-esztétikain kívülre kerülve, hős-mivoltából kivetkőzve él túl ez a figura azon a ponton, ahol eggyé válik, majd

\footnotetext{
${ }^{83}$ Walter Benjamin: „Sors és jellem.” In Angelus Novus, 60. (GS 2, 170.)
} 
rögtön újra el is válik szerző, elbeszélő és szereplő. Ahol a szereplő Köves Gyuri nyíltan megtagadja a klasszikus, sors által meghatározott jellemmel való rokonságot. A könyv fó paradoxona, hogy ennek a kívül-kerülésnek a révén válik a szereplö Köves Gyuri figurája, és még inkább az erre a figurára vonatkoztatott müimmanens külvilág, azzá a mégis lezárt másikká, mely a végső müvészi megformálás elengedhetetlen feltétele.

„Otthon kell éreznünk magunkat más emberek világában ahhoz, hogy a vallomástól eljussunk az objektív esztétikai szemlélethez, az értelmet kutató kérdésektől eljussunk odáig, hogy a világot mint esztétikailag szép adottságot lássuk. Meg kell értenünk, hogy a világ mint adottság igazán értékes meghatározásainak, az evilági jelenvalóság önértékü rögzítéseinek a hőse egyedül az igazolását elnyert, lezárható $>>$ másik $<<$ lehet: Valamennyi szüzsé a >>másikról $<<$ szól, róla költöttek minden müalkotást, érte ejtettek minden könnycseppet, csakis neki állítottak emlékműveket, másokkal van tele valamennyi temető csakis a >>másikat<< ismeri, rá emlékezik, őt teremti újra az alkotó Emlékezet, hogy müvészi legyen a mi emlékezetünk is, mellyel a tárgyakra, a világra és az életre emlékezünk. Kizárólag >>mások<< világában lehetséges az esztétikai, szüzséalkotó, önértékủ mozgás - a múltbéli mozgás, amely a jövőtől függetlenül értékes, amelyben elengedtetett minden kötelezettség és adósság, s felhagytak benne minden reménnyel. A művészi érdeklődés az alapvetően lezárt életre irányul, és kívül áll az értelmen. El kell magunktól távolodnunk ahhoz, hogy felszabadíthassuk a hőst, aki így szabadon mozoghat a szüzsé hőseként a világban." 84

\footnotetext{
${ }^{84}$ Mihail Bahtyin: A szerzö és a hös. 188.
} 
A sorsfogalom kritikájának főbb jellegzetességeit, irányait igyekeztem megadni a fentiekben. A sorsfogalomhoz azonban, amint már ez a fenti gondolatmenetekben is nem egyszer felmerült, eltéphetetlenül hozzátartozik a bünfogalom is. Pontosabban a bünnek egy olyan fogalma kötődik a sorshoz, mely jón és rosszon, felelősségen, döntésen - egyszóval minden etikai reflexión innen van. Sajátos viszony füzi azonban a generációs viszonyhoz, a nemiséghez, a leszármazáshoz, az öröklődéshez, a kultúrához. Hívhatjuk természeti bünnek, eredendő bünnek, tragikus vétségnek - kétségkívül a különböző megnevezések különböző modalitást (filozófiait, vallásit, mủvészi-esztétikait) kölcsönöznek fogalmunknak, de ezek a modalitások, hogy egy ódonnak ható skolasztikus beszédmódot hasznosítsunk újra, egyazon bűn-szubsztancia modalitásai. Legalábbis Mihail Bahtyin gondolatmenetéből ez következik. „Természetesen a klasszikus jellem nem mentes a büntől (a tragédia hőse csaknem mindig vétkes), de vétke nem erkölcsi bün, hanem a lét büne: a bünnek a lét erejével kell rendelkeznie, nem pedig olyan értelmi erővel, mely az ember önmaga feletti erkölcsi ítélkezéséből fakad (a hős nem az értelem ellen, hanem az istenség személye, a kultusz stb. ellen vét). (...) A tragikus bün maradéktalanul a lét mint adottság értéksíkjához tartozik, és a hős sorsának immanens része: ezért a bün tökéletesen kiemelhető a hős tudatából és ismereteiböl (az erkölcsi bün ellenben az öntudat immanens része kell hogy legyen, tudatosítanunk kell benne magunkat mint $>>$ ént $<<$ ) - a tragikus bün átemelhető a nemzetség múltjába (a nemzetség a >>másság $<<$ létének értékhordozó természeti kategóriája). A hős anélkül követhette el a bűnt, hogy gyanította volna tettének jelentését, mindenesetre a bün - mint erő - a létben rejlik, s nem a hős szabad erkölcsi tudatában születik meg, a hős nem a bün ízig-vérig szabad kezdeményezője, itt a lét kategóriájának értéksíkján belül maradunk." ${ }^{95}$ Igaz az, hogy a tragikus bün nem erkölcsi jellegü bün, azonban éppen azzal, hogy a sors rendjén törést okoz, már az erkölcsire utal. Ahogyan

\footnotetext{
${ }^{85}$ Mihail Bahtyin, i.m., 273-274.
} 
Walter Benjamin fogalmaz Franz Rosenzweig gondolatai nyomán a Sors és jellem címü írásában: a tragikus hős „,vétsége” révén rádöbben, hogy különb, mint istenei, különb, mint a kultusz, különb, mint a nemzetség puszta leszármazottja, azonban ez a felismerés megbéklyózza nyelvét, néma marad: nyelv híján mintegy „erkölcsi gyermekségre” születik $^{86}$. Mert az erkölcsi világ minden mozzanata csak a legtágasabban értett nyelvben megnyilvánuló világ mozzanata lehet. Az erkölcs nem lehet néma.

Ennek ellenére kétségtelenül Mihail Bahtyin az, aki A szerző és a hős címü müvének néhány oldalán mủvészi-esztétikai szempontból talán a legpontosabban mutatja fel a leszármazás, a hagyomány, vagy ahogyan ő leggyakrabban nevezi: a nemzetség jelentőségét a sors és a természeti bün esztétikai jellemformáló alakzataiban, Søren Kierkegaard viszont az, aki A szorongás fogalma címü könyvében a nemiség és az eredendő bün kapcsolatának kultúraformáló jelentőségét szemléletes pszichológiai-filozófiai leírással képes ábrázolni. Bahtyin a nemiség problematikájára nem tér ki, jóllehet a nemzetség fogalmába, az anya és az apa fogalmaiba ezt a kifejtetlen problémakomplexumot is nyilvánvalóan beleérthetjük. Itt is magától értetődően inkább a természeti bünről, mintsem a tragikus vétségről van szó, bár analógiák kétségkívül jelen vannak a kettő között. „A cselekvéssor nem bensőmböl hatóan kezdödik, én csak folytatom a sort (mind a gondolatok, mind az érzések, mind a teljesítések cselekvéssorát) - eltéphetetlen fiúi viszony füz a nemzetség által képviselt apasághoz és anyasághoz (itt a szükebb értelemben vett nemzetségről, valamint a nép alkotta nemzetségről és az emberi nemről beszélünk). A $>>$ ki vagyok? $<<$ kérdésében az a kérdés hallatszik: kik a szüleim, milyen nemzetségből származom. Csakis az lehetek, aki már lényegileg vagyok: nem utasíthatom el lényegi már-létemet, hiszen az nem az enyém, hanem anyámé, apámé, a nemzetségé, a népé, az emberiségé." ${ }^{87}$ Nemzetség és sors az értékelő kerete a klasszikus hősnek, függetlenül annak cselekedeteitől (épp fordítva, cselekedeteinek

\footnotetext{
${ }^{86}$ Walter Benjamin: „Sors és jellem”. In uő: Angelus Novus, 65.

${ }^{87}$ Bahtyin, i.m., 274.
} 
értéke függ a nemzetség és sors által rájuk vonatkoztatott kerettől): „A nemzetség értéke a sorsot az emberre irányuló esztétikai látásmód és lezáró tevékenység pozitív értékkategóriájává teszi (nincs szükség az ember erkölcsi kezdeményezésére)." ${ }^{88}$

A tragikus vétségben, megkülönböztetve azt a puszta természeti vagy eredendő bűntől, azonban pont az elutasításnak, a hagyomány, a nemzetség, a sors ellen való öntudatlan lázadásnak jelenik meg a mozzanata. Ez a tragikus vétség átmeneti jellegét eredményezi a természeti és az erkölcsi bün között. Mindenesetre ahhoz, hogy a sorsfogalom kritikáját és ezzel együtt a modern jogi erőhatalomban és büntetés-végrehajtásban is uralkodó mitikus képzetek müvészet felöl kibontakoztatható kritikáját mélyebben megalapozzuk, a későbbiekben a bünfogalom kritikájának azokat az aspektusait kell számba vennünk, melyek a sorsfogalommal vonatkozásba hozhatók. A jog és az erőszak viszonyainak tárgyalásával kezdtük Walter Benjamin Az erőszak kritikájáról szóló írásának vonatkozó részeit vizsgálva. A következőkben vissza kell térnünk ehhez az esszéhez, és azt megvizsgálnunk, hogy hogyan tájolható be az a mozzanat a jogteremtő és jogfenntartó erőhatalomban (Gewalt), mely jog előttinek tekinthető. Emlékezhetünk, hogy Benjamin a halálbüntetés elvi jelentőségében látta meg ennek a mozzanatnak a legvilágosabb jogimmanens jelét. A természeti élet, vagy, Foucault-val szólva, a test feletti korlátlan jogihatalmi uralom jelei legevidensebben a kínzásban és a kínhalálban nyilvánulnak meg. Aiszkhülosz Leláncolt Prométheuszának nyitányában Prométheuszt a kelletlenül parancsvégrehajtó és jóformán együtt érző Héphaisztosz mellett két alak(zat), a jóval készségesebbnek mutatkozó Erőszak és az Erő szegezik a sziklához. A kettő megszemélyesített eszme viszonya homályos a mítosz intenciói szerint is. Kratosz (Erőszak) és Bié (Erő) alvilági eredetü testvérek, fivér és nővér, Sztüx és Pallasz négy gyermeke közül kettő, akik Zeusz állandó kísérői (kvázi-attribútumai) lettek a titánok elleni győzelem után;

\footnotetext{
${ }^{88}$ Bahtyin, i.m., 275-276.
} 
Héphaisztosz konkrétabb figurájával szemben a maguk elvontságával és kísértetszerüségével a mítosz és a filozófia közötti határsávot is jelzik. Figyelemre méltó, hogy az erőszak férfias, míg az erő nőies jelleget kap a mítoszban. Talán a gondolkodásnak is sikerül megtalálni valamilyen finom megkülönböztetés, még inkább megkülönböztetések sorának lehetőségét, melyre a német Gewalt szó többértelműsége és többértékűsége nem pusztán utal, hanem amelyet némiképp óhatatlanul el is maszatol. 


\section{MÁSODIK RÉSZ}

\section{(Antichris $\bigcirc$ )}

„Kérlek, bocsáss meg ezekért a szegényes és előzetes gondolatokért. Csupán ide kellene, hogy elvezessenek engem, oda, ahol Veled remélek találkozni: az ideák a csillagok ellentétben a kinyilatkoztatás Napjával. Nem ragyognak bele a történelem nappalába, csupán láthatatlanul fejtik ki benne hatásukat. Csak a természet éjébe ragyognak bele."

Walter Benjamin levele Florens Christian Ranghoz, 1923. december 9. (Szabó Csaba fordítása)

"Tear down those walls, let the animals out. Tear down those walls, let the criminals out. Let them take their revenge, let their hate fill your mouth." 


\section{Gewalt/Gewalt. Erőszak/erő/hatalom. Mitikus/allegorikus}

\section{természet}

Az erőszak kritikájáról szóló írás a végéhez közeledve egyre sürübbé, mondhatni lapidárissá, utalásszerủvé válik. Az olvasót jó esetben arra készteti ezzel, hogy időzzön el minden egyes mondatnál, és a kontempláció révén figyelmesebbé váljon a nyelvi megformálás mikéntjére is, mely megformálásnak ebben az esetben a korrelatív tartalomhoz való olyan sűrű és sokvonatkozású kötődése figyelhető meg, amilyen egyébiránt jórészt csak irodalmi müalkotásokban, leginkább versekben lelhető fel. A terminusok mint motívumok összjátéka a lezáró bekezdésben erösödik fel a legintenzívebben, ahol a szerző tekintete a jövő felé fordul. Kezdjük ezúttal a lezáró mondatokkal: „Verwerflich aber ist alle mythische Gewalt, die rechtsetzende, welche die schaltende genannt werden darf. Verwerflich auch die rechtserhaltende, die verwaltete Gewalt, die ihr dient. Die göttliche Gewalt, welche Insignium und Siegel, niemals Mittel heiliger Vollstreckung ist, mag die waltende heißen. ${ }^{\circledR 9}$ Bence György fordításában: „A mitikus erőhatalom ellenben minden alakban elvetendő. Úgy is, mint jogteremtő erőszak, amelyet eldöntőnek nevezhetnénk; úgy is, mint jogfenntartó, azaz elrendező erőszak. Az isteni erőhatalmat pedig, mely mindig csak inszigniuma és pecsétje, sohasem eszköze a szent végrehajtásnak, az elvégező erőszaknak nevezhetjük. ${ }^{" 90}$ Három olyan terminusértékủ jelzőt vezet be a szöveg az utolsó mondatokban, amelyeket már értelemszerủen nem használhat a későbbiekben, hiszen nincsenek későbbiek. Ezek a „,haszontalan” terminusok a magyar fordításban a következőképpen alakulnak: eldöntő (a jogteremtésre vonatkoztatva), elrendező (a

\footnotetext{
${ }^{89}$ WB: GS 2, 203. Kiemelések tőlem.

${ }^{90}$ WB: Az erőszak kritikájáról, 54. Kiemelések tőlem.
} 
jogfenntartásra vonatkoztatva), valamint az elvégező (az isteni erőszakra/erőre vonatkoztatva). De mi végre ez a „túldifferenciálás” a lezárásban, amelyből már nem indul tovább elemzés? A magyar fordítás erről nem adhat számot. Az első és végig kitartó elválasztás a jogteremtő és jogfenntartó erőszak/erő között húzódott a szövegben, melyek egymás váltakozó érvényü korrelátumainak mutatkoztak. Mindketten végül is a mitikus erőszak/erő alakjaiként lepleződnek le. A mitikus és isteni erőszak/erő között volt egy másik fontos elválasztás; ezek viszont eddig úgy tünhettek, mint egymást kizáró formák. Ám az isteni vagy tiszta erő/erőszak kapcsán elhangzik az is, hogy biztosan sohasem ismerhető fel az egyes esetekben, „mivel az eröszak [Gewalt] feloldozó ereje [entsühnende Kraft] nem olyan kézenfekvő az ember számára"91. Így végső soron teljes bizonyossággal lehetetlenné is válik a mitikus és isteni erő/erőszak világos elválasztása. Hiszen a mitikus ugyan utólag mindig megítélhetően a bünre ítél, ám az isteni erő/erőszak úgy oldoz föl a bün alól, hogy az (kívülröl) sosem megítélhetö. Az utolsó mondatok nem-hasznosítandó új terminusai tovább erősítik az erőszak-/erőformák átjárható kontinuumként való elképzelhetőségét (Vorstellung - a német kifejezés magában foglal egy halvány utalást a performativitásra, hiszen elöadásként is fordítható). A terminusok ugyanis mind (nem szükebb grammatikai, hanem inkább terminológiai-poétikai értelemben) nyelvi rokonok, bár a rokonsági reláció kétségkívül az utolsó waltende terminus felé gravitál. A német nyelvben állandósult szókapcsolat a schalten und walten, melynek jelentését magyarul hozzávetőlegesen a tennivenni ikerszóval adhatjuk vissza, azzal a fontos megszorítással, hogy a német idióma világosabban magában foglal valami önkényességre, ellenőrizhetetlen hatalomra való utalást: aki a schalten und walten értelmében tesz-vesz, az az úr a házban, annak ki vannak szolgáltatva az emberek és a dolgok. A schaltende a jogteremtő, míg a waltende az isteni vagy tiszta erőszak/erő jelzője; az állandósult szókapcsolatban szereplő mellérendelő

\footnotetext{
${ }^{91}$ ibidem.
} 
kötőszó a kétfajta erőszak/erő látszólagos egyenrangúságát sugallja, a hangalakjuk hasonlósága miatt előálló ikerszó-jelleg pedig világos elválaszthatóságukat kérdőjelezi meg. A verwaltete jogfenntartó erőszakra vonatkoztatott jelzője morfológiailag a walten ragozott formája, mely a jogfenntartás származtatott jellegére utal, fontos azonban az is, hogy ezúttal nem folyamatos, hanem befejezett melléknévi igenévvel van dolgunk, tehát a fordításban szerencsés is lett volna ezt talán így jelölni: elrendezett (és nem elrendező) erőszak/erő. A verwaltete származtatott jellege finoman azt is jelzi, hogy az alapforma, amelyre az összes többi erö-/erőszakforma vonatkoztatható, nem a schaltende jelzővel illetett mitikus/jogteremtő, hanem a waltende jelzővel jellemzett isteni vagy tiszta erőszak/erőforma. A schaltende a waltende „elkorcsosult” (bastardierte) formája. Ám a bastardierte jelzője nem pusztán az előbbi alacsonyabb rendű származására utal, hanem kettőjük rokonságára is. Mindhárom terminusra (schaltende, verwaltete, waltende) igaz, hogy egyáltalán nem a jogi terminológiából származtathatóak, sokkal inkább a köznapi nyelvből. Jacques Derrida jogosan és szellemesen veti fel, hogy a waltende Gewalt felé gravitáló lezárás a szöveg tartalmáért felelősséget vállaló aláírás és (bár jóval korlátozottabb érvénnyel, mint azt Derrida feltételezi) előírás gesztusának tűnhet, amennyiben a szöveget ellenjegyző „Walter” a tartalmat „,belülről” autorizálja, akár egy „új történelmi korszakra” (ein neues geschichtliches Zeitalter) vonatkozó „legyen” (fiat) értelmében is ${ }^{92}$. Ám ennél

\footnotetext{
92 Jacques Derrida, „A törvény ereje”, 260-261. Azonban általában nem olyan problémamentes Walter Benjamin gondolkodásában a „görög” és a „zsidó” viszonya, és nincs is olyan egyértelmü állásfoglalás a „zsidó” mellett, mint ahogyan azt Jacques Derrida szeretné láttatni. Úgy gondolom, eleve bajos görögként és zsidóként beazonosítani a mitikus, illetve az isteni erőszakot, még ha a megfeleltethető példák a szövegben (Niobé / Korach bandája) ezt is látszanak sugallni. Hiszen Benjaminnál a mitikus erőhatalmak, a mitikus erőszak, a sors rendjének áttöretése, a jogmegsemmisités lehetőségének egyik vonulata a „görög” müvészetben, leginkább a tragédiában jelenik meg, másik vonulata pedig a „görög” filozófiában, leginkább a platóni ideatanban és mítoszkritikában jut érvényre (vö. a „Sors és jellem” címü írással, valamint „A német szomorújáték eredete” címü dolgozat ismeretkritikai előszavával és „Szomorújáték és tragédia” címü fejezetével). Ennek fényében nehéz elfogadni az érvényességét Derrida következő értékelésének: „Majd miután felvállalta a Görög és a Zsidó értelmezését, Benjamin aláír. Értékel és előír, nem pedig tudomásul vesz, ahogy azt tesszük minden esetben, amikor aláírunk. Két energikus mondat jelenti be, mi kell hogy legyen a vezényszó, mit kell csinálni, mit kell elvetni, mi a büne vagy perverzitása annak, amit el kell vetni [Verwerflich]." Jacques Derrida: i.m. 260 (kiemelések az eredetiben). Csakhogy: Benjamin szövegében, Jacques Derrida energikus állításaival ellentétben, sehol sincs szó arról, hogy mit kell csinálni. Nincsen semmiféle vezényszó sem. Egyáltalán, a kellésről nincs szó sehol sem. A jog megsemmisítéséről esik úgy szó, mint feladatról. Ez a feladat-kijelölés legfeljebb negatív
} 
még fontosabb a gesztusnak az a tulajdonsága, mely csak a walten másik két korrelatív új terminussal (schalten, verwalten) való viszonyából lesz világos, mégpedig az, hogy ez a gesztus visszamenőlegesen az esszé egész elhatároló terminológiáját, sőt így némiképpen magát a gondolatmenetet is ironikussá teszi, méghozzá annak az iróniának az értelmében, amelyet egy másik fontos korai írásában a szerző félelmetesnek (ungeheuer) nevez. ${ }^{93} \mathrm{~A}$ Biblia bünbeesés-történetét értelmezve Walter Benjamin ezt a félelmetes iróniát a jog mitikus eredetének ismertetőjeleként (das Kennzeichen) azonosítja. Alighanem ez a félelmetes irónia mélyebb rétegét jelenti a sors ama sokat és felelőtlenül emlegetett iróniájának is. „A megismerés fája (Der Baum der Erkenntnis) nem azért állt ott, hogy felvilágosítást adjon jóról és rosszról, amit adni képes lett volna, Istennek kertjében, hanem a kérdező fölötti ítélkezés intő jeleként (Wahrzeichen). Ez a félelmetes irónia a jog mitikus eredetének ismertetőjele. (Diese ungeheure Ironie ist das Kennzeichen des mytischen Ursprungs des Rechtes.)" A terminusok szerveződésének poétikája itt is elbonthatatlanul kötődik a tartalomhoz, és azt is láthatjuk, hogy ezúttal a fordítás is érzékelhetővé teszi ezt az összefüggést. Magyarul rendszerint a tudás fájának, és nem a megismerés fájának nevezzük a bibliai történetben szereplő fát, amelyet a német nyelvben a der Baum der Erkenntnis jelöl. A fordítás figyelmességét dicséri, hogy az Erkenntnis megfelelöjeként megismerés szerepel a tudás helyett itt; többek között abból a szempontból is fontos ez, hogy a nyelv tanúságot tegyen arról az összefüggésről, mely szerint a rejtélyes fa nem csupán intő jel (Wahrzeichen), hanem ismertetőjel (Kennzeichen) is: a megismerés fája tehát ismertetőjel. Az intő jelként fordított Wahrzeichen valójában azonban a német nyelvben maga is rokon értelmü a Kennzeichen kifejezéssel: mindkettő fordítható ismertetőjelként. Annak a

értelemben „ír elő”. A jog hatalmának a megsemmisítéséről lehet egyébként szó, amelyhez a jog és a hatalom (,érdek nélküli”) tanulmányozása, az eröszak/hatalom történelmének filozófiája vezethet el. Ahogy Franz Kafka Bucephalusa, új ügyvédje kapcsán írja Benjamin: „A jog, melyet nem gyakorolnak, a jog, amelyet csak tanulmányoznak: ez az igazságosság kapuja.” (WB: „Franz Kafka”. In Angelus Novus, 816. GS 2, 437.) És azt se vétsük el, hogy a jog hatalmának megsemmisítése nem jelenti egyben a mítosz megsemmisítését. Nemsokára visszatérek még érintőlegesen ehhez a problémakörhöz a föszövegben a verwerflich terminus kapcsán. Lásd még lentebb a 97-es számú jegyzetet a Derrida-értelmezés visszásságairól.

93 „A nyelvről általában és az ember nyelvéről”. 20. GS 2, 154. 
félelmetes iróniával működő sorsfolyamatnak az ismertetőjele ez a fa, hogy az ítélet (Gericht) legelsősorban azt sújtja, aki a cselekvés (külső) mércéjeként és nem (belső) vezérfonalaként érthető jó és rossz megítélhetőségét firtatja azelőtt, hogy cselekedne. Ez a sodródás-szerű sorsfolyamat a döntésképtelenség tevés-vevése (schalten und walten). Hiszen még a „bennem” lévő erkölcsi törvény is, a felettem lévő csillagos éghez hasonlatosan, ebben az értelemben külső mércévé válik. Mert semmilyen „elkövetendő” cselekedet valójában nem ítélhető meg, még formailag sem, elkövetése előtt, nem ítélhető meg egy előre rá vonatkoztatott mérce alapján, csak annyiban (és innen származhat a jog sorsszerü lehetőségének ironikus elve), amennyiben már a cselekedet elkövetését a mércéből fakadó ítéleten való spekuláció formálja és informálja, legyen az a mérce a tisztán formálisnak gondolt kategorikus imperatívusz. A jog (és a neki megfelelő erkölcs!) vonatkozásában a sors valóban félelmetes iróniája pedig abban áll, hogy akinek cselekvését az ítéleten való spekuláció formálja és informálja, az bűnre ítéltetik. „A jog nem büntetésre ítél, hanem bűnre. A sors az élők bün-összefüggése.”94 „Das Recht verurteilt nicht zur Strafe, sondern zur Schuld. Schicksal ist der Schuldzusammenhang des Lebendigen." És ezt úgy érdemes érteni, hogy a jog akkor is bünre ítél, ha nincsen jogi ítélet, vagyis nincsen konkrét büntetés; a jog által uralt erkölcs nem lehet szabad, csakis bün-konstellációkban gondolkodhat. Az erőhatalom/erőszak kritikájáról szóló írás legelején a szerző a feladat természetét így mutatja be: „Az erőszak kritikájának feladatát úgy írhatnánk körül, hogy be kell mutatni az erőszak viszonyát a joghoz [Recht] és az igazságossághoz [Gerechtigkeit]." 95 Már itt sajátos irónia munkál: hiszen bár a német nyelvben az igazságosságot jelentő, a Justiz-tól megkülönböztetett Gerechtigkeit a jogot jelentő Recht szóból származtatható, $A z$ erőszak kritikájáról (és $A$ nyelvről általában... is) szóló írás a jelentések leszármazását megfordítja a nyelvi-grammatikai leszármazáshoz képest, az igazságosság a nyelv

\footnotetext{
${ }^{94}$ Walter Benjamin: „Sors és jellem.” Ford. Tandori Dezső. In WB: Angelus Novus. 63. GS 2, 175.

${ }^{95}$ WB: „Az erőszak kritikájáról”, 28. WB: GS 2, 179.
} 
fogalmilag befoghatatlan eredetének és céljának, míg a jog(i nyelv) a nyelv hanyatlásának és absztrakt eszköz-cél viszonyokra való redukálásának bizonyul, és végső soron a gondolatmenet első meggondolásra meghökkentő módon oda is jut el, hogy ahol az igazságosság van jelen, ott nem lehet jelen a jog. Már csak azért sem, mert az igazságosság nem cél, nem fogalom, hanem idea. Legyen bármilyen kifinomult egy jogi rendszer, minden összefüggése visszavezethető eszköz és cél viszonyára. Az igazságosság „maga” azonban sosem lehet a célom, a célom legföljebb az lehet, hogy az adott szituációban igazságosan cselekedjek, az igazságosság a cselekvésemet orientáló vezérfonál. Az igazságosság nem különíthető el fogalomként egzaktul egy szituáción belül, nem lehet egy szituáció pontosan beazonosítható aspektusa, a szituációban cselekvők igazságossága sosem szavatolható vagy igazolható. Az igazságosság idea, és ennek az ideának a legradikálisabb megfogalmazása a „,szeressétek ellenségeiteket” krisztusi parancsa, mely parancs a jog és az állam számára mindig megbotránkoztató marad. Ez lehet egyben a szabadság pozitív tartalma is. Az igazságosság nem jogos, és nem is jogtalan/jogellenes, mert az igazságosságot sosem lehet (jogos eszközökkel) szavatolni, sosem lehet (igazságosnak mondott célokkal) igazolni: végső soron az igazságosság megítélhetetlen. Az igazságosság megnyilvánulhat (manifestieren), és az igazságosságról tanúságot lehet tenni, vagy pontosabban talán az igazság(osság) tanúságot tesz, tanúságot tehet magáról az emberen keresztül: ennyiben az igazság(osság) részlegesen, töredékesen, esetről esetre, szituációról szituációra felismerhető. Általános érvényű, de nem általánosítható. „Mi lenne akkor, ha úgy állna a dolog, hogy a sorsszerü erőszak minden fajtája, hiába alkalmaz jogos eszközöket [berechtige Mittel], kibékíthetetlen ellentétben van önmagukban véve jogos célokkal [gerechten Zweckenvalójában igazságos célokkal - L.Z.], és ugyanakkor remélhető, hogy létezik valami másfajta erőszak [Gewalt], s az persze nem jogos és nem is jogtalan eszköze ezeknek a céloknak, hanem valahogy másképp kapcsolódik hozzájuk [itt kimaradt egy fontos árnyaló 
mellékmondat a fordításban, tudniillik hogy ez a másfajta erő/erőszak egyáltalán nem eszközként kapcsolódik, viszonyul az igazságos célokhoz: sondern überhaupt nicht als Mittel zu ihnen, vielmehr irgendwie anders, sich verhalten würde]? Ez némileg megvilágítaná azt a furcsa és kezdetben elbátortalanító tényt, hogy végső soron minden jogi probléma eldönthetetlen (a dolog kilátástalanságát talán csak azzal lehet összehasonlítani, hogy az éppen kialakulófélben levő nyelvekben mennyire lehetetlen eldönteni, hogy mi a $>>$ helyes $<<$ és a $>>$ helytelen $<<$ ). Az eszközök jogosultságáról és a célok igazságáról pedig sohasem az ész dönt, hanem az egyiket a sorsszerü erőszak dönti el, a másikat meg Isten. Ezt ritkán látják be, de csak azért, mert makacsul tartja magát a megszokás, hogy az igazságos célokat valamilyen lehetséges jog céljainak vélik, vagyis nemcsak általános érvényünek (ami analitikusan következik abból a tulajdonságukból, hogy igazságos célok), hanem általánosíthatónak is, ami pedig kimutathatóan ellentmond e tulajdonságuknak. Ugyanis azok a célok, amelyek egy bizonyos helyzetben igazságosak, általános elismerésre érdemesek és általános érvényűek, nem tekinthetők ilyennek egyetlen más, mégoly hasonló esetben sem."96 Minden jogi probléma eldönthetetlen: mint jogi probléma. A bíró valójában

\footnotetext{
${ }^{96}$ Walter Benjamin: „Az erőszak kritikájáról.” 48. GS 2, 196. Jacques Derrida többször kitér, főként előadásának második részében, a Walter Benjamin, Carl Schmitt és részben Martin Heidegger elképzelései közötti összefüggésekre. A legkevesebb, ami ezzel a kérdéskörrel kapcsolatban elmondható, hogy a szerző képzelete igencsak élénk, és olyan kijelentéseket és mögöttes tartalmakat tulajdonít Walter Benjamin esszéjének és gondolkodásának, amely jelentés- és tartalom-tulajdonítások semmi mást nem igazolnak, csakis saját rögeszméit. Jellemző tünete ennek a tendenciának az a filológiai könnyelmüség is, hogy a szerző két helyütt is Benjamin és Schmitt „levelezéséröl” (correspondence) beszél. Nos, ilyen levelezés, bármilyen izgalmas is volna, úgy tűnik, hogy nem létezik. Egy rendkívül formálisan megfogalmazott kísérölevél létezik 1930-ból, melyben Benjamin Schmitt figyelmébe ajánlja a szomorújátékról szóló könyvét, és egyúttal azt is megírja, hogy a barokk szomorújáték fejedelméről alkotott elméletében inspirálták Schmitt vonatkozó írásai. Samuel Weber példaszerü filológiai pontossággal és szikár okfejtéssel mutatja be, ahogyan Benjamin szomorújátékról írt szövege végül érvényteleníti Schmitt politikai-teológiai tételeit a fejedelemről, amikor lényegileg döntésképtelennek ábrázolja ezt az alakot. Vö. Samuel Weber: "Taking Exception to Decision: Walter Benjamin and Carl Schmitt." Diacritics, Vol. 22, No. 3/4, Commemorating Walter Benjamin (Autumn - Winter, 1992), pp. 5-18. Érdekes, hogy bár több Carl Schmitt-tel és Walter Benjaminnal foglalkozó értelmezés implicit módon hatályon kívül helyezi Jacques Derrida azon törekvését, hogy közös, proto-nácinak nevezhető horizont alá homogenizálja a két szerző (Benjamin esetében inkább általa ráolvasott, mint igazolt) anti-parlamentarizmusát és felvilágosodásellenességét, mégsem foglal állást egyikük sem Derrida összekacsintásra, valamiféle bennfentes, ezoterikus tudásra apelláló utalásaival szemben. Sőt Giorgio Agamben még meg is idézi egyetértőleg a Derrida-szöveg egy kevésbé problematikusnak tünő részét, látszólag teljesen megfeledkezve arról, hogy utána ő maga is e szöveg kétértelmű utalásainak tendenciájával homlokegyenest ellentétes következtetésekre jut. Vö.: Giorgio Agamben: State of Exception. Trans. by Kevin Attell. University of Chicago Press, 2005. (Ld. főként a 4. fejezetet: Gigantomachy Concerning a Void, 52-64). Carl Schmitt és Walter Benjamin „politikai teológiáinak”
} 
különbségeiről hasznos és invenciózus összefoglalót nyújt az említettek mellett a következő dolgozat: Marc De Wilde: "Meeting Opposites: The Political Theologies of Walter Benjamin and Carl Schmitt." Philosophy and Rhetoric, vol. 44, no. 4, 2011. pp. 363-381. Judith Butler felhívja a figyelmet futólag arra, hogy Derrida értelmezése mennyire tendenciózus: Judith Butler: "Walter Benjamin and the Critique of Violence". In Butler: Parting Ways: Jewishness and the Critique of Zionism. Columbia University Press, 2012. pp. 76-7. Petra Gehring kiváló tanulmánya azonban igen világosan artikulálja nemcsak Derrida Benjamin-értelmezésének visszásságait, hanem magának a Derrida-tanulmánynak a föbb problematikus részeit is ragyogóan exponálja: Petra Gehring: Force and "Mystical Foundation" of Law: How Jacques Derrida Addresses Legal Discourse. In German Law Journal vol. 6, 2005, 151-169:

http://www.germanlawjournal.com/pdfs/Vol06No01/PDF_Vol_06_No_01_151-169_SI_Gehring.pdf (jelen gondolatmenet szempontjából talán a 16-os számú jegyzet lehet a leginkább releváns a 157. oldalon).

Miután jelen dolgozat első részében többé-kevésbé azt próbáltam bemutatni a Sorstalanság címü könyv kritikai értelmezésén keresztül, ahogyan a nemzetiszocialista megsemmisítö-projektum a történelemben a legvilágosabban és legszélsőségesebben tette felismerhetővé annak a hatalomnak a müködését, amelyet Walter Benjamin mitikus erőszaknak és sorsszerü rendnek nevez, itt nem volna szükséges hosszabban állást foglalni Jacques Derrida jelentés-tulajdonításaival szemben, ha nem volna az utóbbi szerző szövegét egy évvel később, 1990-ben újból és másként lezáró Post-Scriptumban (ez a magyar fordításból hiányzik) néhány olyan megjegyzés, amelyeknek a súlyos és akár opportunistának is nevezhető csúsztatásai mellett sajnos nem mehetek el szó nélkül. Az isteni erőszakot ugyanis vértelennek és feloldozónak nevezi Benjamin, és ezt a jellemzést Jacques Derrida ijesztőnek (redoubtable), tolerálhatatlannak (intolerable) tartja, ha a gázkamrákra és krematóriumokra gondol. Értsd: azokban is „,vértelenül” (közvetlen vérontás nélkül, feltehetőleg erre gondolhatott a szerző) haltak meg az áldozatok, és így állítólag a „túlélők”, valamint a „holokauszt múltbeli, jelenbeli és jövőbeli áldozatai” számára felmerül a kísértés (temptation), hogy Walter Benjamin elképzeléseiből kiindulva a „végső megoldás” „vértelen” hullatermelését az isteni erőszak „feloldozó” manifesztumaként értelmezzék. Nos, még ha ez valami feltartóztathatatlan jelentés-lavina vagy -infláció értelmében így is volna, ahogy egészen nyilvánvalóan nincs így, mint igyekszem bemutatni ebben a jegyzetben, de még ha így is volna, akkor is indokolatlan érzésem szerint ez a sápatag moralizáló retorika a „kísértésnek” az „ijesztő” és „tolerálhatatlan” jellegéről. A nyilvános gondolkodás kockázatvállalás. Mindenesetre annak érdekében, hogy alátámassza ennek a képtelen, inkább Walter Benjamin gondolatmenetétől elidegenített terminusokból, semmint gondolataiból kiinduló értelmezésnek a lehetőségét, ez a „vértelen” és „,feloldozó” jelleg empirikus okká és okozattá silányul Jacques Derrida megfogalmazásában: "When one thinks of the gas chambers and the cremation ovens, this allusion to an extermination that would be expiatory because bloodless must cause one to shudder. One is terrified at the idea of an interpretation that would make of the holocaust an expiation and an indecipherable signature of the just and violent anger of God." (Jacques Derrida, i.m. 1044-1045). A szellemeskedés tenyészetének tényleg nincs határa. Fontos ehelyütt kijelenteni, még ha kicsit szégyellem is magam miatta, hogy ilyen evidenciát kell kimondanom: a „végső megoldásnak” nevezett folyamat „lényege”, már ha van olyan, korántsem és semmiképpen sem lehetett az, hogy technikailag túlnyomórészt kikényszerített fulladásos halál, és nagyon nagy, túlságosan nagy részben eleven elégettetés által ment végbe. Egyáltalán: egyrészt a technikai aspektusra (még ha ez a „technikai” aspektus természetesen morális vonatkozásokkal is bír), másrészt a kauzális összefüggésre redukált értelmezés ebben a kontextusban semmi másnak nem nevezhető, legyen egyébként más elemeiben a gondolatmenet bármilyen szellemes, csakis olcsó hatásvadászatnak (föként, ha észben tartjuk az alkalmat szolgáló konferencia címét: Nazism and the Final Solution). De menjünk bele mi is egy kicsit ebbe a hatásvadász retorikába, sőt fokozzuk azt következetesen a teljes nonszenszig: képzeljük csak el azt a fikciót, hogy elmés nemzetiszocialista mérnökök olyan „,módszert”,,fejlesztenek ki”, amelynek segítségével az áldozatok testét minimális idő alatt apró véres húscafatokká lehet ledarálni, a vért pedig kis csatornákon keresztül nyom nélkül elvezetni, és a gázhalál, az elevenen elégetés és a többi halálnem helyett ezt a nem kevésbé humánus módszert alkalmazzák nagyobb hatékonysága miatt a végrehajtó nemzetiszocialista sorsügynökök: ez akár azt is jelenthetné Jacques Derrida gondolatmenetéből kiindulva, hogy akkor Benjamin írása minden további nélkül mégis csak rendben van isteni/vértelen és mitikus/véres erőszakostul, úgy, ahogy Derrida ezeket az aspektusokat ,értelmezi”. Mert másképp nehezen megmagyarázható, hogyan lehet ennyire tendenciózusan félreértelmezni Walter Benjamin egyszerü, bár kétségkívül nem problémátlan kijelentéseit, melyek szerint „,a vér a puszta élet szimbóluma”, valamint, hogy az általa az isteni erőszak példájaként hozott bibliai elbeszélésben mély összefüggés van az isteni erőszak vértelen és feloldozó jellege között. Hiszen már ebből a két utalásból világos kellene hogy legyen, miszerint ez az összefüggés szimbolikus: tehát azt, hogy nem a puszta életre és a hatalomra, a hatalom megszerzésére és fenntartására irányul az erőszak/erőhatalom, azt a megsemmisülés vértelensége szimbólumként jelöli az ószövetségi elbeszélésben, ahogyan Niobé gyermekeinek véres halála éppen az ellenkezőjét szimbolizálja a mítoszban. Ezt Benjamin nem hangsúlyozza külön, de az ószövetségi elbeszélésben nemcsak hogy vér nincs, hanem tulajdonképpen holttestek sincsenek, hiszen Korach és társai alatt megnyílik a föld: testük nyomtalanul eltünik. Ugyanúgy jutnak közvetlenül, nyom nélkül a „,föld 
nem dönt, hanem sorsot diktál (vaktában, mint láttuk: és ez teljesen független az

úgynevezett jogi tényállás jobb vagy rosszabb megítélésétől). A jogi ítélethozatal nem a tett megítélésére irányul, hanem a tett elkövetőjére vonatkozó következmények, a büntetés vagy a felmentés kiszabására. Azonban minden jogi probléma valamilyen döntés, vagy legalábbis valamilyen erkölcsi vonatkozású cselekedet következményeire vonatkozik. Erőszak és jog legelsősorban abban közös, hogy mindkettő erkölcsi viszonyokba avatkozik bele. Ezért nem „természeti képződmény” az erőszak, mint ahogy azt a természetjog szeretné láttatni, ugyanúgy nem az, mint ahogy maga a jog sem: a természetben természetesen jelen van az agresszív viselkedés (amelyet napjainkban leginkább a vulgáris (nem feltétlenül „Szélsőséges”) gondolkodásbeli sémák alakjában jelenlévő szociáldarwinista eszmetörténeti örökség gondolattalan alkalmazói, és köztük kétségkívül bizonyos újnácik is, szeretnek rendkívüli módon túlhangsúlyozni), ám az agresszív viselkedés a fentebb említett okok miatt önmagában nem jelent erőszakot. Természetesen ezt az erőszak és agresszió közötti megkülönböztetést magától értetődőbb megtenni a német nyelvben, amelyben a Gewalt, mint már néhányszor kitértünk rá, nemcsak jogteremtő vagy jogfenntartó erőszakot, hanem akár legális erőhatalmat, és hatásaiban felismerhetetlen „,isteni”, elvégező hatalmat is jelenthet.

alá”, ahogyan Énokh-kal kezdődően néhány „Istennel járó” emberről említi a Biblia, hogy az „égbe” kerültek, „eltünnek”, vagyis Isten „magához vette” őket (Énokh-ról lásd Gen 5, 22-24). Igazából nem tudhatjuk, mi történik velük, ,hova” kerülnek pontosan, és ez ebben a történetben is a döntő, ha úgy tetszik, mesés elem. Tehát szó sem lehet arról, hogy valamilyen (emberek csoportja által elkövetett!) eröszakos cselekedet azért lehet feloldozó, mert „vértelen”, mint ahogy ezt a képtelen utalást Derrida Benjaminnak tulajdonítja. A szimbolikus összefüggés sosem lehet (pusztán) kauzális. Másrészt a Benjamin által hivatkozott ószövetségi elbeszélésben (Számok könyve, 16) az isteni erőszak a hatalom embereire, lévitákra sújt le közvetlenül, fenyegetés és figyelmeztetés nélkül (,emberi”, azaz olvasói nézőpontból tekintve katasztrófaként), mindenfajta közvetítő „,emberi” ügyködés: önjelölt sorsügynökök, vagyis (ön)felhatalmazott gyilkosok, önjelölt, önfelkent forradalmárok, vagy akár Apolló és Artemisz segítsége nélkül. Vagyis elemi ténye a vértelenség kapcsán hivatkozott elbeszélésnek az is, hogy nincsenek elkövetők. Az elbeszélés szerint egyébként Mózes és Áron az isteni döntést még enyhíteni is próbálják az ellenük támadókkal szemben: „Ök pedig arczukra borulának, és mondának: Isten, minden test lelkének Istene! nem egy férfiú vétkezett-é, és az egész gyülekezetre haragszol-é?” (Számok 16, 22, Károli Gáspár ford.) Harmadrészt: az isteni erőhatalom/erőszak fenomenológiailag hozzáférhetőbb analogonja Benjamin értelmezésében a nevelői, szülői erőhatalom (ezzel a vonulattal Derrida természetesen nem foglalkozik): amely úgy sújt (jellemzően a schlagen ige származékait használja mindenütt az isteni erőszak analógiáiban Benjamin), hogy egyben a bün alól (legalábbis részlegesen) feloldoz, és nem teremt precedenst, nem ,jogteremtő" és nem hatalom-fenntartó: ilyen értelemben cél nélküli is. De a nevelői erőhatalom ilyen megnyilvánulása is csak egyik lehetséges, közelítő analógiája lehet annak, aminek sosem ismerhetjük fel bizonyossággal példáját. 
Az eröszak kritikájáról szóló írás lezárásában előkerül még egy terminus, amelyet a fordításban „elvetendőként” olvashatunk: ez a verwerflich. Verwerflich a jogteremtő, schaltende erőszak/erö/hatalom, verwerflich a jogfenntartó, verwaltete erőszak/erő/hatalom. Tehát verwerflich mindenestül a mitikus erőszak, az az erő/erőszak, melynek mindig az egyébként vonzó hatalom (Macht) az elve. Az isteni, waltende erőszak nem kap korrelatív jelzőt; tehát szó sincs arról, hogy az isteni erő/erőszak „,követendő”, ,elvégzendő”, „tételezendő”, valami „feladat” volna, sőt, még arról sem, hogy várakozni vagy vágyakozni kellene rá, hiszen, mint világos már, nem ítélhető meg, hogy hol válik el egymástól isteni és mitikus erőszak, amennyiben az erőszak mitikus aspektusa mindig felismerhető, de az isteni mint olyan bizonyossággal soha. Nem, a feladat semmiképpen sem az isteni erő/erőszak (el)követése, hiszen ez feladatként képtelenség is volna, hanem, mint azt világosan kimondja az írás, a feladat a jog megsemmisítése (Vernichtung), a jogteremtő és jogfenntartó korrelatív hatalom-/erő-/erőszakformák végeláthatatlan körforgásának felszámolása (Entsetzung). Amennyiben beszélhetünk tehát feladatról ebben az összefüggésben, az csakis negatív lehet. Ennek a megsemmisítö/felszámoló projektumnak apró szilánkját tartalmazza minden egyes döntés, melyet nem a jog formál és informál, mely nem ismeri el a fennálló jogot (normát, hivatalos vagy akár pusztán formális morált) a cselekvés mércéjeként. Ebből még nem következik, hogy egy ilyen döntés következményei feltétlenül jogsértőek lesznek, hiszen a döntésben megsemmisül a jog érvénye. Ám másfelől, mint azt nem győzöm hangsúlyozni, az sem következik ebből, hogy egy döntés a következményei alapján esetenként megítélhető és beazonosítható volna úgy, mint az isteni, elvégező erő-/erőszak emberen keresztüli részleges megnyilvánulása. Ami biztos, az az, hogy az ilyen döntés elutasítja a jogot, ám nem világos, és sosem megítélhető bizonyossággal kívülről, hogy pusztán a fennálló jogot utasítja el, vagy a jogot/hatalmat mint olyat. Hogy pusztán nem ismeri el a jogot, vagy egyáltalán nem tart igényt jogra és 
hatalomra. És csak ebben az értelemben tartalmaz halvány előíró jelleget az egyébként csak részben parancsoló modorban megírt lezárás. A lezáró mondatokban kétszer elismételt szó, a verwerflich ugyanis azt is jelentheti, hogy megvetendő, alávaló, alantas. És talán érdemesebb is így érteni, mint elvetendőként (és ezzel egyáltalán nem a fordítás hiányosságára utalok), mely utóbbi jelentés ebben a szövegkörnyezetben mintha valami tettet megelőző választás lehetőségét sugallná, melynek során, akár egy (jogi-)etikai spekuláció végeredménye révén, valamiféle intellektuális elkényelmesedettségben kiválaszthatnánk a felmerülő cselekvések közül a megfelelőt, a nem elvetendőt: az igazságosat (gerecht). Mert ha a cselekvést meghatározó döntés csupán a fennálló jogot, és nem a jogot/hatalmat általában utasítja el, akkor ezt nem is teheti másnak, mint egy új, bevezetendő jognak/hatalomnak (Macht) a nevében. „Rechtsetzung ist Machtsetzung”, mondja Walter Benjamin, ám ennek a tételnek a fonákján ott van az is, hogy Rechtentsetzung ist Machtsetzung. Ezért fontos, hogy ne csak azt az elementáris kétértelmüséget tartsuk észben, amelyet a Gewalt szó magában hordoz, hanem azt a félelmetes és ironikus kontinuitást és körforgást is, mely az erő/erőszak, a jog és a hatalom között vezet végig és vissza, mely a (rechtsetzende) Gewalt aktusától a Recht(ent)setzung és Machtsetzung tényállásán keresztül a (rechtserhaltende) (Staats)gewalt érvényéig és vissza vezet. Ennek a kontinuitásnak a szélső értékeit jelentheti például egyugyanazon szituációban egy Bobby Sands jog-/hatalomellenes, (kvázi-)-prométheuszi megnyilvánulása, valamint egy korabeli belfasti börtönőr szélsőségesen jog-/hatalomkövető magatartása. A Hunger címü film egyik jelenetében ezért is több értelemben találó az a statikus kameraállásból felvett képsor, melyben a tisztítószemélyzet tagja az egyik cella falára koncentrikus körökben, feltehetőleg több rétegben felmázolt emberi ürüléket, úgy tủnik, még nagy nehézségek árán sem képes teljességgel eltüntetni. ${ }^{97}$

\footnotetext{
${ }^{97}$ Az 1981-es éhségsztrájk elött nem sokkal fejezték be azt az akciójukat a PIRA- és INLA-rabok, melynek során igyekeztek katasztrofális egészségügyi állapotokat előidézni a Maze-börtönben. Nem viselték a
} 


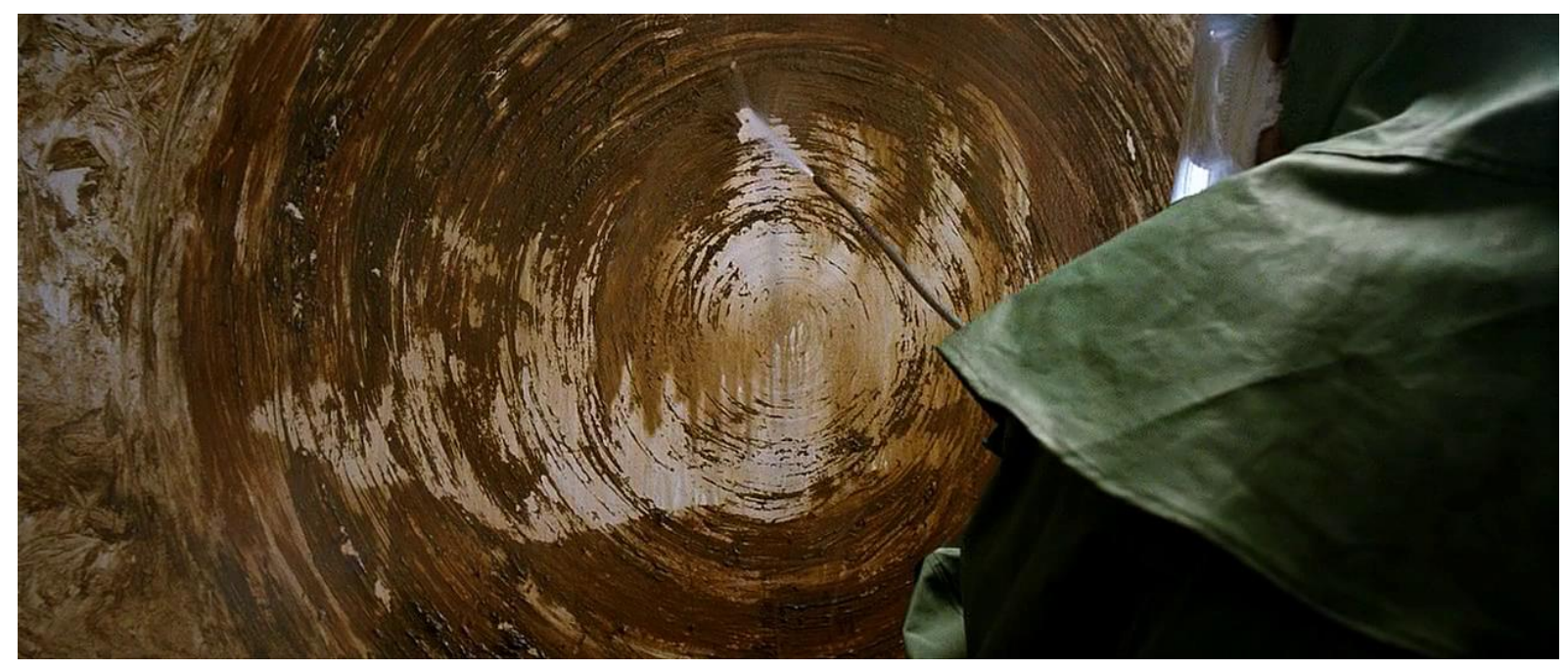

A cselekvések kontinuitása és a körforgásból fakadó, terméketlennek tünő reménytelenség ellenére mégis sejthető talán ma már, és a film feltehető intenciója is ennek a sejtésnek hangot adni, hogy a „történelmi” Bobby Sands által kezdeményezett radikális éhségsztrájk legalábbis részleges feloldozó erőt hordozhatott magában. Másmilyen feloldozó erő emberi cselekvés vagy nem-cselekvés számára nem is igen adódik. A Bobby Sands által kezdeményezett éhségsztrájknak legsajátabb értelmében semmiképpen sem lehetett a hatalom az elve, még ha megfontolandó is, de végső soron nem megítélhető bizonyossággal, hogy mennyiben volt és lehetett az elve az igazságosság. Prométheusz az emberiség ügyét képviseli az igazságtalan mitikus hatalommal szemben, ám egy újabb, igazságosabbnak remélt hatalom jegyében, és épp ez utóbbi mozzanat révén a mitikus hérosz kitüntetett, a ciklikus örökkévalóságban megkínzott szenvedő elítélt alakjaként (még ha megszabadulásának lehetőségét nem is zárja ki, sőt annak reményével kecsegtet a mítosz), és egyúttal a lázadó prototípusaként jelenik meg. Sands filmbeli alakja saját természeti létezésének jogát szélsőségesen feladva, erőnek erejével, ugyancsak kitüntetett módon, ám semmilyen hatalomra igényt nem tartva közvetíti (és szigorú értelemben nem képviseli! a médium helyzetében van inkább) az ír (katolikus) nemzeti egység, valamint, szűkebb értelemben, börtönben raboskodó bajtársai ügyét, szenvedése azonban, ember lévén, időben 
lezáruló, és véges, részleges és vitatható értelmủ is, amely szenvedés gondos, reflektált ábrázolása ezért lényeges, a hamis kultuszt érvénytelenítő, és a halottnak némileg igazságot is szolgáltató hozadékává válhat a filmnek.

Prométheusz mellett egy másik mitikus figura talán még fontosabb szerepet kap $A z$ erőszak kritikájáról szóló Benjamin-esszé gondolatmenetében. A mitikus erőszak megnyilvánulását és jogteremtő erejét Niobé története példázza. Ha Prométheusz a lázadó, a „nagy bünöző”, akkor Niobé a bünhődő és a gyászoló prototípusa. Vegyük észre a közvetlenül érzékelhető természet legélettelenebb és legmozdulatlanabb alkotórészének, a kőnek az állhatatos jelenlétét az érintett mitologémákban. Prométheuszt sziklához láncolják. Niobé apja az alvilág egyik legismertebb fogvatartottja, Tantalosz, aki fölött örök fenyegetésként egy hatalmas szikla függ. A másik híres fogvatartott, Sziszüphosz vég nélküli ismétléssel görgeti fölfelé szikláját a hegyre, és Ovidius mély intuíciójú elbeszélése szerint reménytelen munkáját csak a zene képes felfüggeszteni ideiglenesen. Mikor Orpheusz dalban kérleli Hadésztól és Perszephonétól Eurüdikét, az alvilágban egy pillanatra minden bünhődés felfüggesztődik:

Míg zengette a dalt, s pengette szavához a lanthúrt, sírtak a vértelenült lelkek; nem kapkod a tünő habhoz Tantalus, Ixion torpan kerekével, nem tépnek madarak májat, sem a belosi lányok nem meregetnek; Sisyphus, ülsz szikládra nyugodva. ${ }^{98}$

\footnotetext{
${ }^{98}$ Publius Ovidius Naso: Átváltozások. Fordította Devecseri Gábor. Magyar Helikon, 1964. Tizedik könyv: Orpheus és Eurydice. 286. „Talia dicentem nervosque ad verba moventem / exsangues flebant animae; nec Tantalus undam / captavit refugam, stupuitque Ixionis orbis, / nec carpsere iecur volucres, urnisque vacarunt / Belides, inque tuo sedisti, Sisyphe, saxo.” P. OVIDI NASONIS METAMORPHOSEON LIBER DECIMVS; http://www.thelatinlibrary.com/ovid/ovid.met10.shtml
} 
Niobé alakja azonban fokozatilag különbözik tőlük: ez az alak maga válik kővé. Niobé teste a bünhődés szimbólumává változik át. Nem halott testté. Csak az halhat meg, aki élt. Niobé teste élettelenné válik: mintha nem is élt volna. Thébaiból nem is a Tartaroszba, hanem szülőhazájába, Lüdiába, a Szipülosz hegyének egyik ormára kerül kővé vált teste. Ez a mozzanat teszi Niobét határfigurává a mítosz és a bün viszonyában. Ahogy Walter Benjamin fogalmaz, Niobé ,élete a bűn örökké néma hordozója, s az istenek és az ember közti határ jele [Markstein der Grenze]."99 A német kifejezés itt: Markstein der Grenze, vagyis, kissé furcsa kifejezéssel, a határt jelölő határkő, azaz Niobé valójában az istenek, vagyis a mitikus erőhatalom archetipikus birtoklói, és az ember közti határt jelölő határkő (a Markstein már önmagában határkövet jelent). Van ebben a határkőben egyébként valami hermaszerü is; elég, ha csak a hagyományosan hozzá társított természeti képződménynek, a jelenlegi Törökország területén található maniszai Szipülosz-hegy ormának képét idézzük fel.

\footnotetext{
${ }^{99}$ Walter Benjamin: „Az erőszak kritikájáról”. 49. WB: GS 2, 197, az egész mondat így szól németül: „Trotzdem sie [i.e.: die Gewalt] Niobes Kindern den blutigen Tod bringt, hält sie vor dem Leben der Mutter ein, welches sie durch das Ende der Kinder nur verschuldeter als vordem als ewigen stummen Träger der Schuld wie auch als Markstein der Grenze zwischen Menschen und Göttern zurückläßt."
} 


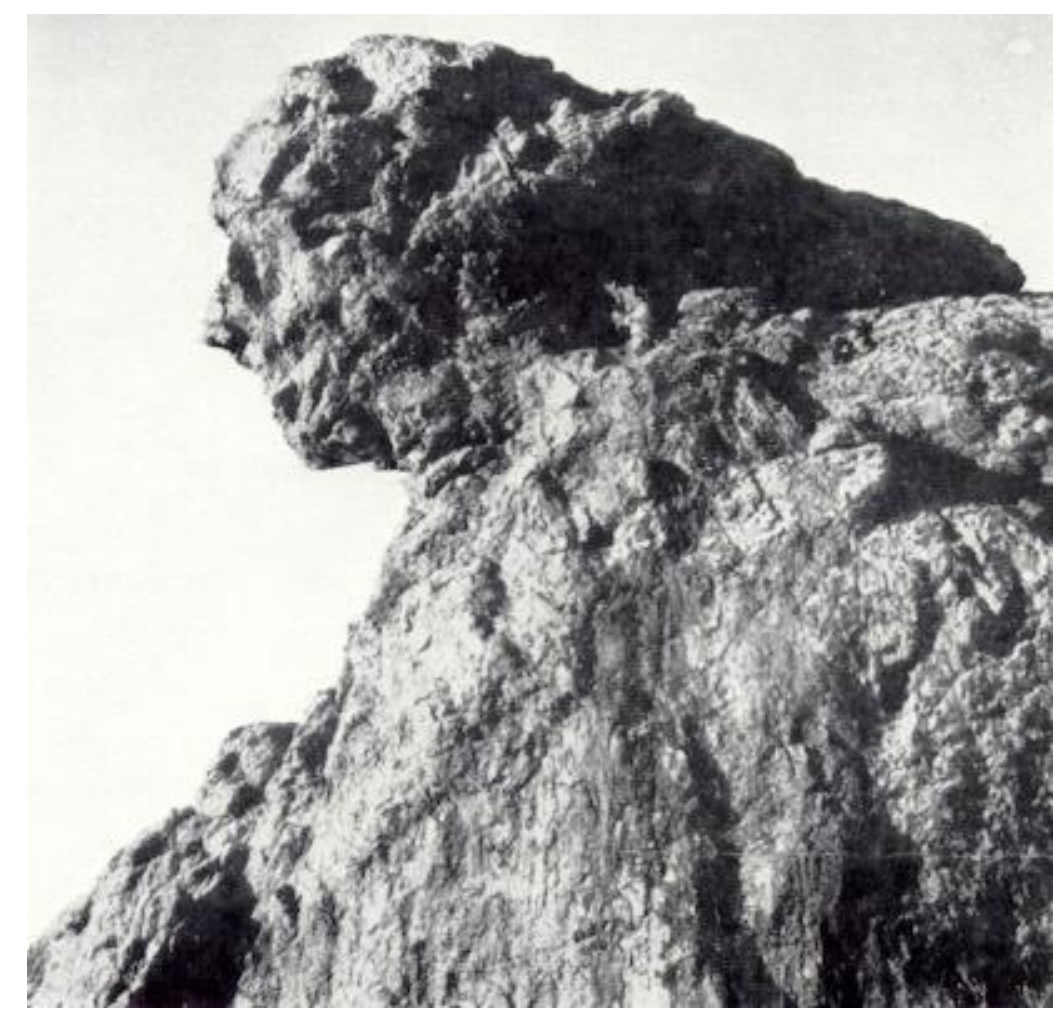

A hermák a tájékozódást segítő útjelzőként és határkőként is funkcionálhattak. A herma ősi formája az arc és a fallosz ikonikus alakzatait foglalja magába. Itt utóbbi természetszerüleg hiányzik, ám a nemiségre, pontosabban a nemiség termékenységaspektusára való negatív utalás megtalálható a mítosz elbeszélésében.

Niobé alakjának viszonya azonosulása, metamorfózisa révén a bünhöz jóval radikálisabb, mint a fentebb említett férfi-héroszoké. Itt már magából a mitikus alakból kibontakoztatható a mítosz kritikája. Ennek a Niobé figurájából kiinduló kritikának az alapmotívumait Walter Benjamin néhány észrevétele előlegezi meg, Judith Butler érzékeny és termékeny továbbgondolása ${ }^{100}$ pedig további irányait és lehetőségeit bontja ki.

Niobé gyermekei halála után életben marad, „még bünösebben, mint valaha”"101. Talán még pontosabb volna úgy fogalmazni, hogy Niobé valójában a gyermekei halála révén, tehát bünhődése révén lesz bűnös. Hiszen a „hübriszről”, a Létó kárára elkövetett, saját

\footnotetext{
100 Judith Butler: „Walter Benjamin and the Critique of Violence”. In Butler: Parting Ways. Jewishness and the Critique of Zionism. Lásd föként a78-9., valamint 89-90. oldalakat.

${ }^{101}$ Walter Benjamin: „Az erőszak kritikájáról”. 49.
} 
termékenységétől és „,boldogságától” elbódult dicsekvéséről csak retrospektíve, pontosabban „retroaktíve” derül ki, hogy bün. Niobé kővé, élettelen (de nem halott!) természetté válva a „bün örökké néma hordozója”. Ám ez a némaság már nem annyira a bünre, hanem inkább Niobé elementáris gyászára, szomorúságára utal. Niobé elnémult alakja a bibliai bünbeesés utáni természethez hasonló hangoltságú: a meglakolásban való megkötöttsége, bün általi túldetermináltsága, fecsegés általi túlnevezettsége szomorúságra és némaságra hangolja. Egyedüli megnyilvánulása a sosem-szünő könnyezés, a panasz hatalom nélküli, önmagát kiszolgáltató kifejezése. Szavakká, egyáltalán differenciáltabb nyelvvé nem formálódhat ez a panasz, csak a legredukáltabb, szótlan, sőt hang nélküli, néma megnyilvánulásra. Judith Butler szerint Niobé könnyei egy olyan alakzatot nyújthatnak a gondolkodás számára, melynek révén megérthetjük a mitikus és az isteni erö/erőszak közötti átmenetet (amely sokatmondóan „,csendben” játszódik le): a mitikus jogteremtő erőszak megfelelőjeként egy olyan jogszerü moralitás áll elő, mely csak kauzálisan megfeleltethető bün-bünhődés-büntetés konstellációkban tud gondolkodni; míg ha elképzeljük, hogy Niobé könnyei egyszer feloldják kőalakját, ahogyan a folyó morzsol szét lassan köveket, akkor legalábbis közelítőleges, felvillanó képet kaphatunk arról a megsemmisítő feloldozásról, amelyet Benjamin szerint az isteni erő/erőszak végez el (walten). ${ }^{102}$ Így Niobé mitikus erőszak/hatalom által elrendelt örök némasága és

\footnotetext{
102 Judith Butler, i.m. 89-90. "Benjamin seems to suggest that the notion of an extramoral transience allows for an apprehension of human suffering that exposes the limits of a notion of morality based on guilt, the metalepsis of a moral causality that produces paralysis, self-berating, and endless sorrow. And yet there seems to be something of endless sorrow that Benjamin preserves from this account. After all, Niobe not only regrets what she has done, but mourns what she has lost. Transience exceeds moral causality. As a result, it may be that Niobe's tears provide a figure that allows us to understand the transition from mythic to divine violence." "One could say that Niobe caused her punishment and that she is guilty of arrogant boasting. But the fact remains that it was Leto who thought up that punishment and ordered the murders of Niobe's children. It was as well Leto's children, Apollo and Artemis, who implemented her legal authority, thus constituting its legitimacy retroactively. Only with that punishment does law emerge, producing the guilty and punishable subject who effectively conceals and effects law-instating power. If divine violence is not involved in the making of law, but mobilizes the messianic in its powers of expiation, then divine power would release the punished subject from guilt. What would Niobe's expiation look like? Can we imagine? Would justice in this case require a conjecture, the opening up of the possibility of conjecture? We can imagine only that the rock would dissolve into water, and that her guilt would give way to endless tears. It would no longer be a question of what she did to deserve
} 
szomorúsága egyben, mondjuk így: ennek a meglakolásnak a fonákján, egy olyan

szomorúság-megnyilvánulás lehetősége, amely a feloldozás, a bűntől való megszabadulás,

és így egyúttal a szabad megnyilvánulás és a boldogság előrejelzésévé, vagy pontosabban

talán befogadójává teheti a gyászoló alakot. Niobé nemcsak az istenek és emberek, hanem

az élet és a halál közötti határkő is. A gyász megformálódásaként, mintegy sírkőként. A

gyász ugyanis nemcsak a kedves halottra, hanem a halotton keresztül mindig a halálra is

emlékezik; a gyász mindig memento mori is egyúttal. De csak az élő gyászolhat, akit a

gyász megbénít, megdermeszt, cselekvésképtelenné, szótlanná, életében élettelenné vagy

életképtelenné tesz. Niobé ennek a gyásznak az ősalakja. Örökké bünbeesettként és

szomorúként, gyászolóként, a mitikus erőhatalom által elnémítottként és e hatalomnak

egyben kiszolgáltatva, hatalom nélküliként van kilátása a megváltásra, akárcsak a Genezis-

beli Isten által az ember bünbeesése után megátkozott természetnek. A természet nagyon

hasonlóképpen lehet kiszolgáltatva a rajta hatalmaskodó embernek, mint Niobé a mítosz

such a punishment, but of what system of punishment imposes such a violence upon her. We can imagine her rising up again to question the brutality of the law, and we can imagine her shedding the guilt of her arrogance in an angry refusal of the violent authority wielded against her and an endless grief for the loss of those lives. If that sorrow is endless, perhaps it is also perennial, even eternal, at which point it is her loss and it is also part of the "downfall" that links her loss to the rhythms of destruction that constitute what in life is sacred and what of life makes for happiness."

„Mintha azt sugallná Benjamin, hogy az erkölcsön túli mulandóság fogalma az emberi szenvedés olyan fölfogását teszi lehetővé, amely megvilágítja korlátait a bünre alapozott moralitásnak, a morális okozatiság metalepszisének, amely megbénít, önváddal és vég nélküli szomorúsággal terhel meg. Mégis, mintha megőrizne valamit Benjamin ebből a vég nélküli szomorúságból. Végső soron nem pusztán bánkódik tette miatt, hanem gyászolja is azt, amit elveszített. A mulandóság meghaladja a morális okozatiságot. Ebből kifolyólag Niobé könnyeit olyan alakzatot nyújthatnak számunkra, amelynek révén sikerül megértenünk a mitikusból az isteni erőszakba tartó átmenetet."

„. Lehet azt mondani, hogy Niobé okozta saját büntetését, az arrogáns hencegés bűnébe esve. Ám az a tény, hogy a büntetést Létó találta ki, és ő rendelte el Niobé gyermekeinek meggyilkolását. Létó gyermekei, Apollón és Artemisz ültették át a gyakorlatba anyjuk jogi autoritását, ekképpen visszamenőleg is legitimálva azt. Csak a büntetés révén jelenik meg a jog, megteremtve a bünös alanyt, aki hatékonyan rejti el és lépteti hatályba a jogot beiktató hatalmat. Az isteni erőszak viszont nincs jelen a jogteremtésben, hanem mobilizálja a messiásit föloldozó ereje révén: az isteni hatalom föloldja a büntetett alanyt bünéből.

Hogyan történhet meg Niobé föloldozása? El tudjuk ezt képzelni? Az igazság ebben az esetben talán egy feltételezést követel meg, egy feltételezés lehetőségének a megnyílását. Csak úgy képzelhetjük, hogy a sziklát egyszer fölmorzsolja a víz, és Niobé büne vég nélküli könnyezéssé változik. Nem az lesz akkor a kérdés, hogy mit tett, amivel kiérdemelte büntetését, hanem inkább az, hogy milyen büntetési rendszer kényszerít rá ilyen erőszakot. Elképzelhetjük öt, ahogy ismét felkel a jog brutalitása ellen, megkérdőjelezi azt, az arrogancia büntudata pedig átadja helyét az őt ért erőszakos bánásmód dühös elutasításának, valamint az elveszített életek fölötti vég nélküli gyásznak. Ha ez a szomorúság vég nélküli, akkor talán állandó is, vagy akár örökkévaló, amely ponton ez egyaránt Niobé vesztesége, valamint része ama „bukásnak”, ami összeköti az ő veszteségét a rombolás ritmikájával: ez a ritmika alkotja azt, ami az életben szent, ami az életből hozzájárul a boldogsághoz." (Saját fordításaim.) 
isteneinek és a mitikus jogteremtő erőszaknak. A természeten a Genezis szerint az ember uralkodik. A bünbeesett természeten, vagyis saját természetén, és így potenciálisan a bünön is: mint ahogy az a Káinnak szóló intésben, még a testvérgyilkosság elkövetése előtt elhangzik: ,„a bűn az ajtó előtt leselkedik, és reád van vágyódása; de te uralkodjál rajta” (Gen 4,7, Károli Gáspár ford.). Ez az intés és parancs értelemszerüen az ősbün, vagyis az első gyilkosság elkövetése után is érvényben marad. Fontos azonban, hogy az eredendőnek nevezett bün, a bünbeesés, melynek szimbolikus képe a tiltott gyümölcs leszakítása a tudás fájáról, lényegileg homályosabb és emberi értelemben szankcionálhatatlanabb, mint ez a konkrét gyilkosság. Hiszen az ítélkezés és szankcionálás lehetősége már csak ebből a tiltott tudásból származhat. Ahogyan a hatalmaskodás, úgy a feloldozás lehetősége is a legtágasabban értett nyelvben van. A bünbeesést követően azonban a természet „elnémul”. A bűnbeesés utáni természet szomorúságáról és elnémulásáról szóló gondolatokkal első ízben Benjamin nyelvfilozófiai tanulmányának lezárása előtt találkozunk. „A bünbeesés után Isten szavával, mely megátkozza a földet, mélységesen megváltozik a természet tekintélye. Ekkor kezdődik a természet másféle némasága, az, melyet a természet mély szomorúságaként gondolunk el. Metafizikai igazság, hogy minden, ami természet, panaszolkodni [klagen] kezdene, ha nyelvnek adományát kapná [wenn Sprache ihr verliehen würde]. (Ahol is $>>$ nyelvet adományozni $<<$ mindazonáltal több mint $>>$ azt tenni, hogy beszélni tud $<<$.) Ennek a mondatnak kettős értelme van. Először is azt jelenti: a természet magáról a nyelvről panaszolkodna. Nyelvnélküliség [Sprachlosigkeit]: ez a természet nagy fájdalma (és megváltása [Erlösung] miatt van a természetben az ember élete és nyelve, és nem csak a költöé, mint véljük [nicht allein, wie man vermutet, des Dichters]). Másodrészt pedig azt mondja a mondat: a természet panaszolkodna. A panasz pedig a nyelv legdifferenciálatlanabb, hatalom nélküli kifejezése, szinte csak az érzéki leheletet tartalmazza: és mindenütt, ahol csak növények zúgnak és susognak, ott mindig panasz is 
csendül [und wo auch nur Pflanzen rauschen, klingt immer eine Klage mit]. Mert néma, ezért szomorkodik, gyászol [trauert] a természet. Ám még mélyebben vezet be a természet lényegébe e mondat megfordítása: önnön szomorúsága némítja el a természetet. Minden szomorúságban, gyászban ott a legmélyebb hajlam a szótlanságra, nyelvnélküliségre, és ez végtelenül több mint a közlésre való képtelenség vagy kedvetlenség. A szomorú úgy érzi, keresztül-kasul megismerte őt a megismerhetetlen. Megnevezve lenni - még akkor is, ha a megnevező valaki Istenhez hasonló és üdvözült -: ez talán mindig is a szomorúság, a gyász sejtelme [Ahnung] marad. De mennyivel inkább áll ez a megnevezettségre, ha nem a nevek boldog üdvözült paradicsomi nyelvéböl történt a megnevezés, hanem a sok-sok emberi nyelvből, amelyekben a név már hervadozott, és amelyek Isten szava szerint mégis megismerik a dolgokat."103 A német szomorújáték eredetéről szóló dolgozat lezárásához közel Benjamin saját korábbi szövegét részben csaknem szó szerint idézi, részben parafrazálja, más keretbe helyezi, és némiképp ki is egészíti, sőt módosítja: ebből a kiegészítésből és módosításból pedig az a következtetés adódik, hogy minden nemmegnevező, nem-konkrét, ítélkező és absztrakt „emberi nyelv” eredendően allegorikus, vagyis „,bűnös”. A középkori elképzelésben Benjamin értelmezése szerint a „bűnös”, allegorizáló teremtmény, az ember beavatkozástól (és felelősségvállalástól) tartózkodó szemlélődése révén „rántja magával” a természetet a bünbe. Ehhez a szemlélődéshez kapcsolódik a melankólia mint a szellem betegsége és az acedia, a jóra való restség mint halálos bűn. Ennek megfelelően a következőképpen módosul a természet szomorúságáról szóló szöveghely folytatása a szomorújátékról szóló dolgozatban a korábbi, nyelvfilozófiai tanulmány hasonló szöveghelyéhez képest: „Megnevezve lenni - még akkor is, ha olyasvalaki a megnevező, aki Istenhez hasonló és az üdvösség részese -: ettől talán soha nem választható el a szomorúság valaminő sejtelme. De mennyivel inkább erről van szó,

${ }^{103}$ WB: „A nyelvröl általában...”, 20-21. GS 2, 155. 
amikor nem neveznek meg, csak olvasnak, bizonytalanul olvas maga az allegorizáló ember, és csak az ő személye révén tesznek szert különös jelentőségre. [Wie viel mehr aber, nicht benannt, sondern nur gelesen, unsicher durch den Allegoriker gelesen und hochbedeutend nur durch ihn geworden zu sein.]"104 Azonban az allegorizáló olvasás intenciója maga is ambivalens, mint az a következő mondatból kiderül: „Másrészt minél inkább úgy érezték, hogy az antikvitással együtt a bün súlya alatt nyög [schuldbeladen empfunden wurden] a természet, annál kötelezőbb lett allegorikus értelmezésük, hiszen ez volt megmentésük [Rettung] egyedül lehetségesnek tünő módja. Mert a melankolikus eszme a tárgynak e tudatos rangfosztása közben is páratlan módon hű marad a tárgy dologiságához."105

${ }^{104}$ Walter Benjamin: „A német szomorújáték eredete.” 437. GS 1, 398.

105 ibidem. 


\section{A bünbeeső természet}

„Minden ember magától megérti, hogyan keletkezett a bün; de ha mástól akarja megtanulni, akkor pont emiatt félreérti."

„Ha statisztikai táblázatokat készítünk a bün helyzetének áttekintésére, és olyan térképeken ábrázoljuk azt, amelyeken színek és magassági vonalak segítik a gyors tájékozódást, akkor végezhetünk olyan kísérleteket, amelyben a bünt a természet különös, nem kiküszöbölhető, de a légnyomáshoz vagy a csapadék mennyiségéhez hasonlóan számokba foglalható képződményének tekintjük; és a középérték, az átlag, amit kapunk, egészen máshogy lesz értelmetlen, mint a tisztán empirikus tudományokban."

„A feladatunk természetesen az, hogy a nemit beleszőjük a szellem meghatározásába.

(Ebben rejlik az erotikus összes erkölcsi problémája.)"

Søren Kierkegaard, A szorongás fogalma 
Lars von Trier a zárójelenetet követően Andrej Tarkovszkijnak ajánlja Antichrist címü 2009-ben bemutatott filmjét. Tarkovszkij Tükör (Zjerkalo) címü 1970-ben bemutatott filmje úgy kezdődik, hogy egy tizenegynéhány éves fiú bekapcsol egy televíziót. A film nézője, a filmben szereplő fiúhoz hasonlóan, nézi a műsort, amelyről az lehet az első benyomása, hogy archív dokumentum, olyannyira elüt a film egészének megformáltságától statikus beállításaival, amatőrnek tetsző operatőri munkájával (a falon például látszódik egy belógó puskamikrofon árnyéka). A müsorban egy erősen dadogó fiút gyógyít meg egy csapásra, varázslatos hirtelenséggel, hipnózis-szerü szuggesztiós módszer segítségével egy médiumként viselkedő, külsejében egyébiránt merőben átlagos, kissé túlzottan kifestett középkorú nő. A nő módszere abból áll, hogy elsőként mozdulatlanná merevíti a Jurij nevü fiú kezeit, majd, hogy így akadozó nyelvéhez hasonlatosan tevés-vevésre szolgáló keze is használhatatlanná vált, a két területröl egyszerre „távolítja el” a fixációt. Végül Jurij valóban folyékonyan és hangosan kijelenti: tudok beszélni. A jelenet magának a film egészének az ironikusan is értelmezhető allegóriája: a rendező ebben a filmjében a tévéműsorban szereplő médiumhoz hasonlóan ad nyelvet a természetnek, pontosabban a film nyelve által feloldja a természet némaságát. A lassú kameramozgással, hosszú snittekben felvett természeti képek, kivált az önálló helyváltoztató mozgásra képtelen növényeket megmozgató szélfúvásokról, a mozgások és időtartamok poliritmikus relativizálásával az idő mozdulatlanná merevítését igyekeznek modellálni, vagy kvázi-profetikus módon megjövendölni; azt a látomást lassan mozduló, ritmikus képpé rendezni, hogy, ahogyan azt a Jelenések Könyvében szereplő angyal mondja, a megváltott világban idő többet nem lesz ${ }^{106}$. A filmben fő természeti motívumként szereplő

\footnotetext{
${ }^{106}$ Jel 10,5-7: „És az angyal, a kit láték állani a tengeren és a földön, felemelé a kezét az égre, és megesküvék arra, a ki örökkön örökké él, a ki teremtette az eget és a benne valókat, és a földet és a benne valókat, hogy idő többet nem lészen, hanem a hetedik angyal szavának napjaiban, mikor trombitálni kezd, akkor elvégeztetik az Istennek titka, a mint megmondotta az ö szolgáinak és prófétáinak." (Károli Gáspár ford.) Tarkovszkij Dosztojevszkij nyomán hivatkozik erre az újszövetségi szöveghelyre „A megörökített idő” című esszéjének mottójában (ld. Andrej Tarkovszkij: A megörökített idő. Ford. Vári Erzsébet. Osiris, 2002. p. 55.) Az Ördögök
} 
szél kiváltképpen olyan természeti jelenség, melynek müködését valójában, paradox módon, csak a mozgókép képes rögzíteni. A természetet közvetítő képek és hangok a Tükörben mind a megváltott, a bűntől és a történelem terhétől megszabadított természet látomását jelenítik meg.

Az Antikrisztus nyitójelenete egészen másképp szolgál a rákövetkező film megelőlegezésének. A Prológusnak (Prologue) nevezett jelenet elsősorban a drámai expozíció feladatkörét tölti be, ám rengeteg olyan utalás van elrejtve benne, amelyek a későbbiek értelmezéséhez kulcsként is szolgálhatnak, és össze is zavarhatnak. A jelenet cselekménye összefoglalható egy bővített mondatban. Miközben egy nő és egy férfi önfeledten szeretkezik, két-három évesnek tűnő, vigyázatlanul hagyott gyermekük kizuhan az emeleti ablakukon, és meghal. A rákövetkező első fejezet címe ennek megfelelően: Gyász (Grief). Ám már ebben a prológus-jelenetben tetten érhető a filmnek az a sajátossága, ahogyan az önmagukban jelentéktelennek tünő tárgyakat, gesztusokat, mozdulatokat és magukat a természeti lényeket (a későbbiekben fát, füvet, páfrányt, őzet, rókát, hollót, csillagokat stb. és bizonyos értelemben ide sorolhatjuk az „embert” is) erőszakos allegorézis révén túldeterminálja, konstruált jelentés-összefüggésekkel terheli túl. A másik oldalról tekintve ez a technikai elv egy túlhajszolt poétikai-gazdaságossági tényezőt is magában foglal, amely nagy részben felelős a film klausztrofób atmoszférájáért (hiába a nyílt természeti terek, sőt!). A filmben ugyanis nincs olyan jelenség, amely megmenekülne a kizsákmányoló vagy épp túltelítő, ám a meghatározatlansági tényezőt mindig magában foglaló jelentés-beruházásoktól és jóslat- vagy

című regényben Kirillov és Sztavrogin párbeszédében Sztavrogin említi a Jelenések Könyvének vonatkozó részét. „,[Sztavrogin:] A Jelenések-ben az angyal megesküszik, hogy idő többé nem lészen. [Kirillov:] - Tudom. Ez ott nagyon találó; világos és pontos. Amikor az ember mindenestül eléri a boldogságot, akkor idő többé nem lészen, mert nem lesz rá szükség. Nagyon találó gondolat. [Sztavrogin:] - Hát hová dugják? [Kirillov:] - Nem dugják sehová. Az idő nem tárgy, hanem fogalom. Kialszik a tudatban.” Eddig idézi a szöveghelyet Tarkovszkij a mottóban. Pedig érdekes volna a folytatás is, főleg az elbeszélő megjegyzései miatt: „,[Sztavrogin:] - Régi filozófiai közhelyek, ugyanazok örökké az idők kezdete óta - dörmögte valami finnyás sajnálkozással Sztavrogin. [Kirillov:] - Ugyanazok! Az idők kezdete óta ugyanazok, és sohase másfélék! - kapott a szón villogó szemmel Kirillov, mintha az eszme már-már maga a győzelem volna.” Fjodor Mihajlovics Dosztojevszkij: Ördögök. Ford. Makai Imre. Bp. Európa: 1983. p. 287. Ismeretes, hogy mind Kirillov, mind Sztavrogin végül is öngyilkosok lesznek. 
motívum-funkció kényszertől: röviden szólva ebben a filmben semmi és senki sem lehet ártatlanul vagy szabadon csak önmaga, mindig jelentenie kell egyúttal valami mást is. Nagyon hasonlatos ez a technika a sorsráolvasó technikákhoz: asztrológiához, jövendőmondáshoz, álomfejtéshez, átokhoz; időnként egybe is esik velük. És művészi-konstruktív elvként szimmetrikus ellentéte Tarkovszkij eljárásának, aki, épp ellenkezőleg, a természet minden elemét, sőt minden reáliát igyekszik felszabadítani, megtisztítani a rájuk rakódott kulturáliscivilizációs-technikai (túldeterminált) tehertétel alól és jelentésszennytől, megnyitva így számukra reményei szerint azt a lehetőséget, hogy a nézőben spontán szimbolikus jelentéseket keltsenek fel. Míg az előbbi technika veszélye a tézis-szerüség eluralkodása vagy pusztán a túlzott önkényesség és szolipszizmus, úgy utóbbié az esztétikai-narcisztikus parttalanság. A két rendező többnyire elkerüli azt, hogy ezek a veszélyességi tényezők a filmjeik állagát teljességgel bekebelezzék; persze nem minden esetben érezhetjük ezt, és ahogyan Tarkovszkij életmüvében a Tükör, úgy Lars von Trier eddigi filmjei közül az Antikrisztus tekinthető tünetszerünek, és némiképp szélső pontnak a filmmüvészeti elv veszélyei és izgalmassága tekintetében is. Ebben az összefüggésben nyer értelmet az Antikrisztus végén megjelenő, Tarkovszkijnak szóló ajánlás. Van ennek az összefüggésnek egészen nyilvánvaló, motivikus tanújele is. Jellemzően a természet láthatatlan, csak hatásában érzékelhető jelenségéről, a szélről van szó. Nagyon árulkodó Andrej Tarkovszkij ars poeticáját és technikai preferenciáit illetően az a szöveghely, ahol a rendező maga magyarázza meg a Tükör címü filmje elején először felbukkanó szélmotívum funkcióját: „A filmszerü kifejezésmódnak nincsenek technikai problémái, ha pontosan tudjuk, mit szeretnénk mondani, és pontosan érzékeljük filmünket, kívülröl látva minden egyes kockáját. Például abban a jelenetben, mikor a Tükör hősnője véletlen találkozik azzal az ismeretlen férfival, kinek szerepét Szolonyicin játszotta, fontos volt számunkra, hogy a férfi távozása után mintegy továbbvigyük azt a szálat, mely összekötötte ezt a két embert, kik láthatóan véletlenszerüen találkoztak. Ha a férfi távozóban 
egyszerüen csak azért fordult volna meg, hogy egy kifejező pillantást vessen a hősnőre, egyértelművé és hamissá vált volna minden. És ekkor jutott eszünkbe, hogy támadjon fel a szél a mezőn, melynek váratlansága magával ragadja az ismeretlent, és megfordulásra kényszeríti. Ebben az esetben nem érhetők tetten egyoldalú alkotói szándékok.

Ha a néző számára nem tárulkoznak fel a rendezői eljárások használatát magyarázó okok, akkor a néző hinni fog a vásznon történtek valószerüségében, elfogadja a művész saját megfigyeléseit megalapozó életet. Ha azonban a néző $>>$ rajtakapja $<<$ a szerzőt azon, ahogy mondani szokás, hogy $>>$ kilóg a lóláb $<<$, vagyis pontosan megérti, minek és miért alkalmaz az alkotó még egy $>>$ kifejező $<<$ fogást, s azonnal felhagy azzal, hogy átélje a vásznon történteket, hogy együtt érezzen mindazzal, amit lát, ehelyett bírálni kezdi az alkotói koncepciót és annak megvalósítását."107

Számos másik szöveghelyet idézhetnénk annak bemutatására, ahogyan Tarkovszkij elméleti gondolkodásában rejtetten az az előfeltevés munkál, mely szerint az „alkotói koncepció” és „megvalósítás” kritizálhatósága, a konstruktív technika áttetszősége egyenértékủ annak elhibázottságával. Figyeljük csak meg, mennyire ártatlanként, mennyire kényszer-jelentésesség nélküliként van elképzelve a szél motívuma a kérdéses jelenetben és egyébként a film egészében is. A másik előfeltevés, amelyik tetten érhető itt, az az, hogy a nézőnek át kell élnie a vásznon történteket, sőt együtt kell éreznie a látottakkal. Ez egyébként Tarkovszkij filmjeiben így is történhet jobbára, tehát saját filmművészetére érvényesek ezek az előfeltevések, ám úgy hiszem, nem kell érveket felsorakoztatnom amellett, hogy általános művészetelméleti alapvetésként, mert a rendező-szerző ebben az összefüggésben így hivatkozik rájuk, már nemigen állják ki az elfogulatlan kritika próbakövét. Érdekes ellentmondás egyébként, hogy Tarkovszkij kedvelt filmrendezője az a Luis Buñuel, akinek főként kései filmjei épphogy inkább távolságtartásra késztetik a nézőt, és a legtöbb esetben az

\footnotetext{
${ }^{107}$ Andrej Tarkovszkij: A megörökitett idő. Ford. Vári Erzsébet. Bp.:Osiris, 2002. 110-111.
} 
sem valószínű, hogy a jelenetek megtekintése során a néző együtt érezne a látottakkal, hiszen azok jobbára kizökkentik a figurákkal és a történtekkel való empátiából, és reflexióra késztetik őt. Inkább azzal érzünk együtt, ami/aki nem látható ezekben a kései Buñuelfilmekben.

De az idézett szöveghely a szél motívuma miatt volt elsősorban fontos számomra. Az Antikrisztusban egyértelmüen Tarkovszkij-parafrázisnak tekinthető az, ahogyan a hirtelen feltámadó szél többször is felbukkan a filmben. Két alkalommal is megelölegezi a férfiszereplő látomását, ,álmát”, tehát filmnyelvileg a szél folytonosságot jelentő átjárást jelöl álom/látomás és ébrenlét/látás között. Vagyis: a szél az egyik kulcs, amely megnyitja az allegorikus jelentés-tulajdonítások káoszát. A film világában ez a megnyitás katasztrofális következményeiben valóban Pandora szelencéjének felnyitásához mérhető. A Tarkovszkijjelenethez hasonlóan a széllökés egyébként irányítja is, vagy épp eltéríti a szereplö figyelmét. Mind a két látomás a természetben történik: az első a fenyvesben, a második egy páfrányoscserjés mezőn. Ezekről később. A két alkalom között azonban még egyszer megjelenik az erős szélfuvallat, ezúttal nem a nyílt terü természetben: ekkor az erdei házikó ablakát csapja ki a szél, miután a nő-szereplő apokrif Baudelaire-idézetként kijelenti, hogy „,a természet a sátán temploma” („Nature is Satan’s church.”). Az lehet a néző benyomása, hogy szavainak ilyen mágikus a hatása: szelet támasztanak. Míg Isten szava közvetlenül teremtő, a filmben a női szereplő szavai idézik meg a természet mitikus, emberfeletti, pusztító hatalmait, magának a szereplőnek biztosítva ezzel egy nem-emberi, a mitikus alakokhoz közelítő, démonikus médiumszerü árnyalatot. Ám a film és a színész, Charlotte Gainsbourg karakterformálása mesterien vagy kissé még azon is túl: veszélyesen, mindvégig fenntartja a zavarba ejtő ambivalenciát a mitikus-démonikus alak és az emberi alak között. A fent említett jelenetben végül a férfi-szereplő felugrik, hogy becsukja az ablakot, miközben a nő-szereplő még 
hozzáteszi: „,itt is van: ez az ő lélegzete” (,Well there you have him. That was his breath.”). Márhogy a Sátáné, nem másé.

Ez utóbbi jelenet biztos nem tetszett volna Tarkovszkijnak.

Az Antikrisztus címü film megértéséhez mindenekelőtt a cselekménynek azt az egyébként triviális tényét kell felidézni, hogy a történet két szereplője, jóllehet a civilizált polgáriértelmiségi társadalom tagjai, már a kezdet kezdetén (a cselekmény perspektívájából nézve: eleve) elszigetelt ettől a polgári-értelmiségi társadalomtól. Ez az alapszituáció az egyik olyan sajátsága a filmnek, amelyet látszólag a horrorfilm müfajától kölcsönöz, de amelyet a többi kölcsönzött müfaji jelleghez és elemhez hasonlóan átalakít, allegorikusan szinte túlterhel, és ezzel az egyirányú jelentés-megfejtéseket el is lehetetleníti. Egyszóval az egyszeri horrorfilm-fogyasztó (mint absztrakt befogadói attitüd) legalábbis zavarban lesz a film megtekintésekor.

A polgári társadalomtól (és részben az emberi kontinenstől) való elszakadást a nyelvben nem is lehet pontosabban jelezni, mint a névtelenséggel. Ezeknek a figuráknak nincs nevük. De nem rendelkeznek a mesehősök névtelen ártatlanságával sem, mely utóbbi körülményt pedig az fejezi ki, hogy a stáblistán a női és férfi „grammatikai” nemre bomló angol harmadik személyű személyes névmáspár jelöli névként a figurákat (She és $H e$ : a továbbiakban én a magyar nyelv eltérő sajátságaiból kiindulva a Nő és Férfi jelöléseket fogom használni, de kérem az olvasót, próbálja ezeket grammatikai és nem-grammatikai értelemben névmásként, és ne főnévként érteni). Banálisnak látszhat, mégis igen fontos az a tény is, hogy a mai angol nyelvben a harmadik személyü névmás női és férfi alakja bizonyos értelemben a jelzett emberi mivoltára is utal: ha a harmadik személyü névmás 
állatra, növényre vagy élettelen tárgyra mutat, akkor rendszerint semlegesnemű (it). A film figuráit ezek szerint névtelen emberi nevük révén a nemiség jelölője határozza meg elsősorban. Ezek az alakok csak nemiségük révén ölthetnek emberi testet. Tovább súlyosbítja ezt a helyzetet, hogy az Antichrist címben az utolsó „t” betüt a női nem egyezményes szimbóluma () helyettesíti. Ennek a behelyettesítésnek igencsak komplex dialektikus következményei vannak a film egészére nézve, és pusztán látszólagos és szándékosan félrevezető az a triviálisan kínálkozó értelmezés, mely ennek alapján a film női alakját azonosítaná az Antikrisztus alakjával.

A cselekmény epikai elemei alapján kézenfekvő, hogy az Antikrisztus címü film női alakjának alapszituáltságát első megközelítésben Niobé mitikus bünhődéséhez és feloldozásra váró gyászához hasonlítsuk. Gyermekét veszíti el ő is: egy olyan lény halálát gyászolja, akinek létezéséért és életéért nagy részben ő is felelős volt. A filmbeli elbeszélésben is a természeti-érzéki élet túlcsordulását, a „boldogságot” követi a szerencsétlenség és a gyász. Niobé történetétől eltérően a szexualitásnak itt nem a termékenység-aspektusa hangsúlyos a Prológus képsoraiban, hanem az erotikus öröm ájultsága, öntudaton kívülisége. Azonban itt is arról van szó, hogy a Nő gyásza a „,bün” következményeként tételeződik majd: egy olyan bün miatt lakol meg, Niobéhoz hasonlóan, mely bűn csak a bünhődés révén kapja meg jelentését. Az erotikus ájulat eredménye hasonlóképpen bizonyos jelek és figyelmeztetések figyelmen kívül hagyása, mint az öntelt dicsekvés szédületéé.

Az ájulás az első, Gyász/Szomorúság (Grief) című fejezet kezdő, a Prológusnál is némább (hiszen a Prológus alatt halljuk a híres és kissé túlhasznált Lascia ch ’io pianga címü Handel-áriát a Rinaldoból) jelenetében valóban, „fizikailag” is megtörténik. A kamera a halottszállító autó belsejének hátrafelé tekintő perspektíváját veszi fel: kifelé néz a koporsót 
szállító autó hátsó, pára- vagy esőcseppekkel foltozott szélvédőjén, melyet a gyásznép, elején az apával, a Férfival, kissé hátrébb az anyával, a Nővel követ. Az arcokat szemből látja a néző, azonban csak a Nő és a Férfi vonásai kivehetőek, a többiek arcvonásai elmosódottak. A Nő viszonylagos lemaradását feltételezhetően az indokolja, hogy járás helyett inkább vonszolja magát: láthatólag nehezére esik a mozgás. A Férfi járás közben igen intenzíven, dinamikusan és látványosan, de könnyek nélkül sír. A Nő arca megviselt, ám kifejezéstelen, fegyelmezett, merev: szoborszerü. Ám úgy tünik, a fegyelmezett fájdalomtürés mégis megköveteli a maga jussát: néhány lépés után a Nő összeroskad; a Férfi, miután kis idő után ezt a tényállást konstatálja, gyorsan odalép és lehajol az ájult testhez.

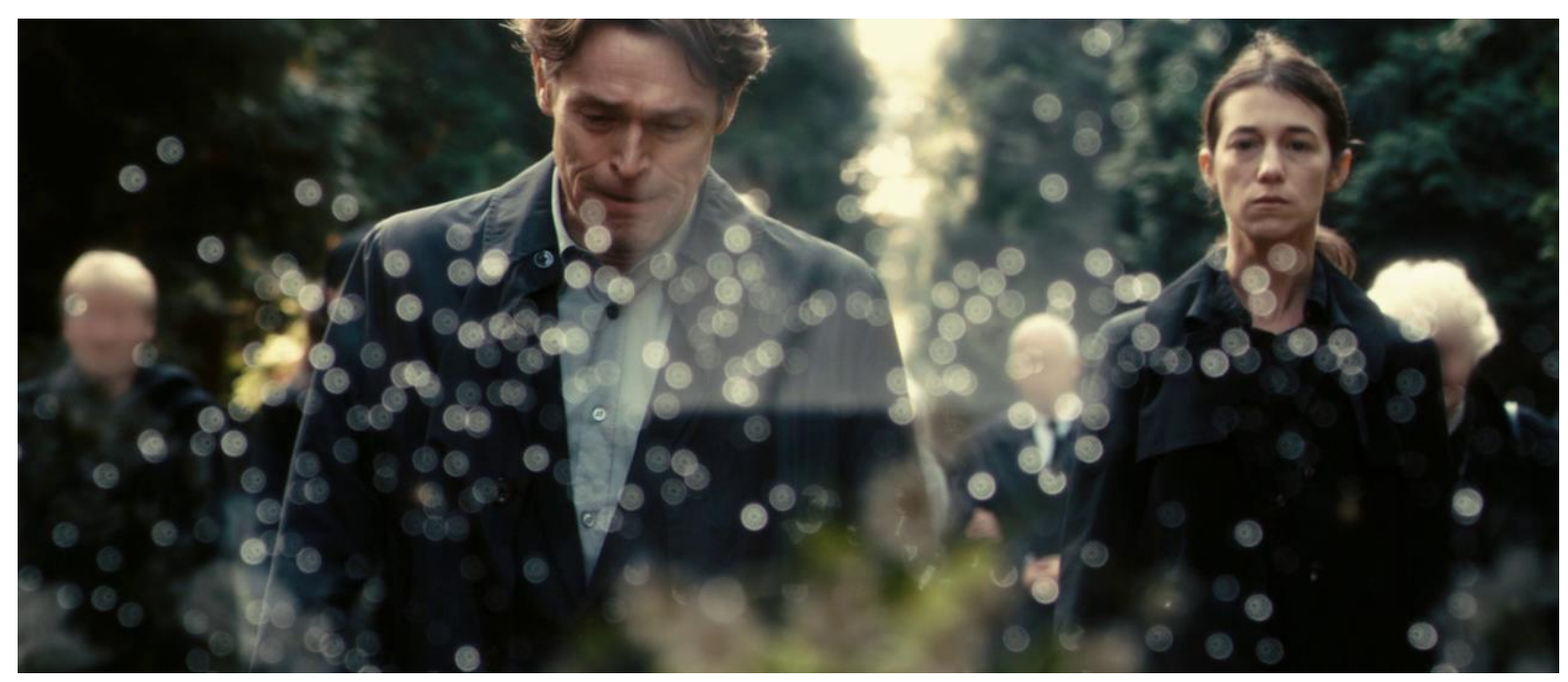

A vágás után egy kórházi kórteremben vagyunk. A Nő a kórházi ágyon fekszik, a Férfi belép kék vágott virággal a kezében. A rákövetkező, a filmben színre vitt első dialógusból megtudjuk, hogy eltelt egy hónap az előző jelenethez képest, ám a Nőnek, feltehetőleg az erős nyugtatók hatása miatt, elmosódott az időérzéke, és feltehetőleg képlékennyé vált az emlékezete is. Azokról a Nő által a néhány kórtermi dialógus során elmondott mondatokról, amelyek ekkor még pusztán enyhe önvádképző rögeszmének tűnhetnek, a kompozíció későbbi elemei felől tekintve derül majd ki, hogy (önbeteljesítő?) bün- és bünhődésképző 
jóslatfunkcióval bírnak. A nehéz, „,nem-tipikus” gyászmunka (a Nő elmondja a Férfinak, hogy pszichiáter orvosa, dr. Wayne szerint az ő, a Nő gyászmunkája nem tipikus: „,Wayne says my grief pattern is atypical"; ez a pszichiátriai-pszichológiai zsargon viszont tipikusan semmitmondó, tehetjük hozzá), a mélyen munkáló szomorúság során éppenséggel nem szokatlan az önvádaskodásnak az a kissé eltúlzottnak tetsző mértéke, amellyel a Nő itt előáll, miszerint a gyermek halála az ő hibája volt („It was my fault”). Ez a legelső tétel, mellyel minden mélyen ülő, önvádaskodó és szorongó gyász előáll így vagy úgy. Ami azt illeti, kissé szofisztikusan, ám nem teljesen hamisan fogalmazva, egy gyászoló szülő részéről ez a tétel mindig tartalmaz igazságot, hiszen amennyiben a szülő gyermeke születéséért, életeeért, úgy legalábbis részben haláláért is óhatatlanul, ha nem is feltétlenül morálisan, de természetben felelős. Itt a Nő részéről persze nem ilyen szofisztikus a tétel; egészen konkrét mulasztásról beszél. Azt állítja, hogy megállíthatta volna a fiát („I could have stopped him”), hiszen ő tudta, hogy az utóbbi időben felkel éjjelenként, jobban kellett volna figyelnie stb. Mindenesetre a Férfi úgy dönt, hogy kihozza a Nőt a kórházból, és saját maga fogja inkább kezelni. Merthogy időközben a párbeszédekből közvetve kiderült, hogy a Férfi pszichológus, és kifejezetten ellenzi és károsnak tartja a pácienst csaknem katatónná gyógyszerező pszichiátriai kezelést. Nincsen semmi nem-tipikus a Nő gyászában („,There is nothing atypical about your grief”), mondja a Férfi, a gyász természetes, egészséges reakció, nem betegség, nem lehet csak úgy eltávolítani, teszi még hozzá. A Nő azonban ellenvetésként felhozza, hogy dr. Wayne tudja, hogy a Férfi pszichológus, és szakvéleménye szerint nem volna szabad a saját családtagját kezelnie. A Férfi „ellenérve” (hiszen elvben egyetért dr. Wayne-nel, de... „In principle I agree, but...”) erre az, hogy ő „szereti” a Nőt, és semmi sem fáj jobban, mondja, mintha azt látjuk, hogy akit szeretünk, hibáknak és tévedéseknek van kiszolgáltatva. Hiszen egyetlen más kezelőorvos sem tudhat annyit a Nőről, mondja a Férfi, mint ő, mármint a Férfi. Aki „szereti”. A ,szeretet/szerelem” 
posztulálásával, a „szeretlek” kimondásával, ami mögé már nem lehet kérdezni, amelynek kimondása a polgári-értelmiségi, szentimentális szimatát fenntartások nélkül követő pszichologizáló elképzelés szerint minden ellenérvet ellentételez, „mintha az eszme mármár maga a győzelem volna”, a Férfi mindenesetre negatíve tematizálja is a továbbiakat, ezután már nincs több kórtermi szó, erősödő zúgó-morajló hang közben a kamera a két szereplő közé fókuszál, egy üvegvázában hagyott, a Férfi által feltehetőleg jó néhány napja hozott vágott virágok száraira közelít lassan, végül egészen közel kerül, a szárak közé, a „vízbe”. A vázában láthatólag nemigen cserélték a vizet, a virágok hervadnak. Az Antikrisztus cím egyik értelme éppen egy ezzel az elhanyagolt és elsietett szeretetreprezentációval analóg mozzanat, mégpedig az, hogy ebben a filmben az alakok, bár más és más okok miatt, de mindinkább képtelenné válnak a szeretetre.

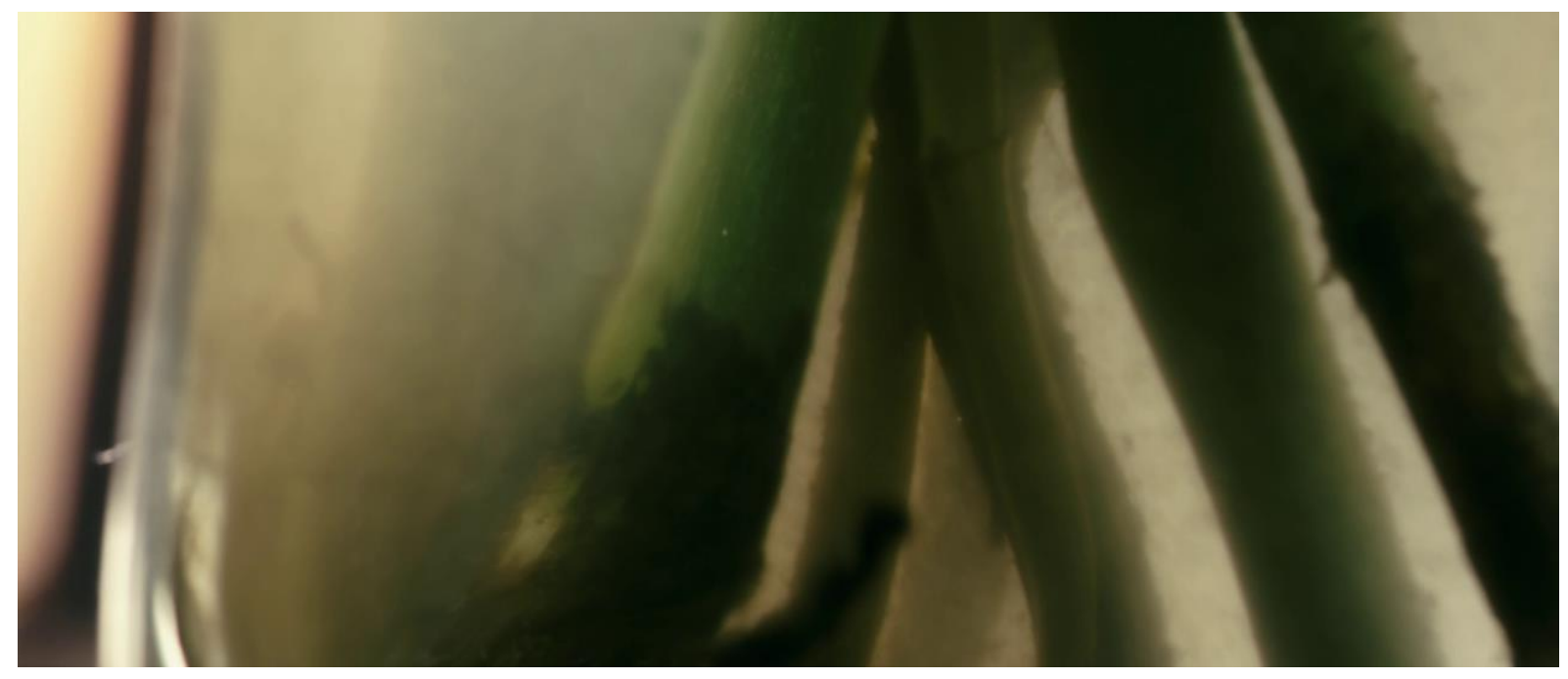

A Niobé-mondától való eltérés az is, hogy a Nő-figurát itt egyáltalán nem jellemzi semmilyen hübrisz vagy akár intellektuális arrogancia. Az arrogancia vádja a filmben éppen hogy a Férfi-figurát illeti, ahogyan azt a második fejezet egy jelenetében, már a „civilizációtól” távol lévő erdei házban a Nő, miután dühkitörése után a Férfi lefogja, fenyegető mosollyal, enigmatikus jóslattal megtoldva olvassa rá a Férfira: “You shouldn't 
have come here. You're just so damn arrogant. But this may not last. Ever thought of that?" Ez az első jelenet, ahol a Nő láthatóan szándékosan, dühkitörés-szerủen támad rá a Férfira. Ha úgy tetszik, ez az első tiszta erőszak-megnyilvánulás. A filmidő felénél vagyunk. A dühkitörést megelőzően a Nő arról számol be az erdei kunyhóban a Férfinak, hogy már korábban, a gyermek halála előtt is érzett megmagyarázhatatlan szorongást a természetben. A kamera mutatja a Nő elbeszélésében újra-elevenedő visszaemlékezés-jelenetet. Mikor a gyermekkel kettesben tartózkodnak az erdei házban, egy alkalommal meghallja a gyermek sírását. Keresni kezdi, egyre kétségbeesetten, a sírást közben kitartóan halljuk, majd egyszer csak a Nő megtalálja a gyermeket a fáskamrában. A kamera mutatja a gyermeket, amint az szemmel láthatóan elégedetten játszik egy fahasábbal. A síró hang tehát nem az ő hangja. Az ekkor még játékként szereplő fahasáb pedig az egyik fő rekvizituma a film allegorikus motívum-rendszerének, és megint csak ironikus jóslat-jellegü itt e tárgynak a szerepeltetése: hiszen ez a fahasáb lesz az a „fegyver”, amellyel később a Nő, a torz-mitikus meglakolás démonikus médiumaként, „,boszorkányként”, az első brutális erőszak-cselekményt hajtja végre a Férfi támadásnak kiszolgáltatott, merev nemi szerve ellen. Mindenesetre a most tárgyalt motivált visszaemlékezés-jelenet során azt látjuk, hogy Nic (ez a gyermek neve, neki van egyedül „,valódi” neve a filmben a láthatatlan dr. Wayne mellett) matat ezzel a fahasábbal, de a sírást továbbra is halljuk. A Nő motivált emlékezet-perspektívájában vagyunk. A motivált jelző azért fontos, mert a narráció egyre bizonytalanabbá teszi a film menete során azt, hogy a visszaemlékezés-jelenetek mennyire feleltethetőek meg a korábban megtörtént „valós”, tényszerü eseményeknek, vagy mennyiben inkább egy erős képzelettel megáldott-megvert, szélsőségesen szubjektív-narcisztikussá váló bün-önvádkonstrukció eredményei. A legszervetlenebbül illeszkedő és a cselekmény alapmotívumát leginkább kétértelművé tevő ilyen visszaemlékezés-jelenet a Nő öncsonkítása előtt történik meg: a Prológus fekete-fehér képsorait értelmezi át a film cselekményidejébe inszcenírozott 
konstruktív-emlékezeti munka. Az ollót remegő kezében tartva, és a gyermek halálával egyidejű erotikus ájultságot fizikailag is visszaidézve a Nő saját emlékezete szerint a Prológus-beli szeretkezés közben látja, ahogy Nic felmászik az ablak előtti asztalra. Ez erősen árnyalja azt a korábbi kijelentését, hogy megállíthatta volna a gyereket. A Prológus során egyébként a Nő szeme a megfelelő jelenetnél végig csukva van. Ebben a szélsőségesen motivált visszaemlékezés-jelenetben a gyermek kizuhanását követően megjelenik a gyászt és szomorúságot allegorizáló őz az ablakban. Az állat megjelenése nyílt utalás az emlékezeti munka bủntudat által motivált konstruktív és feltehetőleg torzuló jellegére, egyben pedig a film világának, elbeszélés- és kifejezésmódjának arra a sajátosságára, hogy álom, emlékezet, képzelet, látomás és józan ébrenlét határai sehol sem markánsak, hanem minden irányból keresztül-kasul és jórészt észrevétlenül átjárhatóak. És nagyon fontos, hogy ebben az esetben sincs semmilyen bizonyosságunk az emlékezés tárgyilagosságának mértékéről. A másik, korábbi visszaemlékezés-jelenetben, miután a gyermeket megtalálta a fáskamrában elégedetten játszani a fahasábbal, az történik, hogy miután a sírást továbbra is hallja, a Nő tovább keresi a forrását, visszamegy a ház előtti tisztásra, hitetlenkedő-kereső tekintettel fordul szembe a kamerával, amely megmutatja még, ahogy a Nö felnéz az ég felé, mire a kamera hirtelen felfelé daruzik, majd megáll és panoráma-képet ad az erdős-párás dombokról, a középen húzódó völgyszurdokkal; a sírást pedig továbbra is halljuk. A következő jelenetben, a korábban már említett, a természetet a Sátán templomával azonosító kinyilatkoztatást megelőzően a Nő kissé szomorkásan beszél a tölgyfák ágairól hiábavalóan, értsd: a továbbszaporodás minden reménye nélkül lehulló makkokról: azok csak hullanak és hullanak, és elhalnak és elhalnak: ennek a hiábavaló elmúlásnak a megértése tette őt alkalmassá arra, mondja, hogy meghallja azt, amit azelőtt nem: minden mulandó dolog panaszát (“And now I could hear what I couldn't hear before: the cry of all the things that are to die."). Mintha megtanulta volna „olvasni” a teremtett és 
bünbeesett természet néma dolog-nyelvét, a luciferi-alvilági végtelen szomorúság névtelen és hangtalan megnyilvánulását. Ennek a tanulásnak az első, meghatározó élményét idézheti fel a síró hang forrását hiábavalóan kereső visszaemlékezés-jelenet. Az erdős-dombos vidéket mutató panoráma-állókép aztán, miután a síró hang forrása végül is lokalizálhatatlanul kiterjed a völgyszurdok egészére, áttünik (a visszaemlékezés-jelenet vége) a Nő barna hajára: a közelről fényképezett női haj nemcsak a kultikus japán horrort, $A$ kör (Hideo Nakata: Ringu, 1998) címü filmet idézi, hanem újra és inkább utal Tarkovszkij Tükör címü filmjére is, ahol lassított felvételen látjuk, ahogy az anyát is játszó Margarita Tyerehova arcába omló hosszú haját mossa. A női haj is többek között a hiábavalóan elhaló, szép természet rekvizitumaként szerepel itt. Mindenesetre még mindig a Nő hajára áttűnő képsor végét látjuk, mikor újra a film elsődleges elbeszélésidejében vagyunk, és megszólal a Férfi érzéketlen és terméketlenül tudálékos, szájbarágós megjegyzése, mondván, hogy a Nő nem Nic sírását hallotta ( "You didn’t hear Nic's screaming. ”). A Férfi otromba megjegyzésével egyúttal a minden filmbeli eseményt a cselekmény kauzális rekonstruálása érdekében hiábavalóan racionalizálni akaró nézői szólamot is megszólaltatja. A Nő a megjegyzés hallatán félrefordítja fejét, mintegy „felébred” a visszaemlékezésből, és talán kicsit ironikusan-rezignáltan jegyzi meg: „Nyilván nem. [Apparently not.]”. Aztán a Férfi a maga iskolás-fafejü pszichológiájával elmagyarázza, hogy minden bizonnyal azért helyezte a szorongás-piramis magas fokára a Nő a családi szóhasználatukban Édennek nevezett, erdei házukat körbevevő területet, mert valami olyat tapasztalt ezen a helyen, amit racionálisan képtelen volt megmagyarázni. Ez az okos magyarázat mindennél inkább a Férfi empátiára való alkalmatlanságáról tanúskodik. Elevenen mutatkozik meg a két jelenet közötti kontrasztban, valamint a Férfi érzelmi süketségében a módszeres diszciplínaként felfogott modern (a filmbeli Férfi-szereplő esetében egy kissé határozatlan ideológiai körvonalú, kognitív irányú) pszichológia terminusainak gyakran célt tévesztő és hiábavaló 
absztrakciója, és így ezzel annak a sekélyesen pszichologizáló-megfejtő alakformálásnak az implicit kritikája is, amely a jellegzetesen hollywoodi filmprodukciók és a megfelelő nézői elvárás-horizontok sajátja jószerint. Terméketlen túlmagyarázásában odáig jut el a Férfi, hogy kijelenti: a sírás nem volt valódi (“The scream wasn't real.”). Erre következik a Nő első, fentebb említett dühkitörése és kódolt fenyegetése. Talán annak reményében történik a támadás, hátha azt a Férfi már képes valóságként érzékelni; azért, hogy lerombolja a terminusok áthatolhatatlannak gondolt falát, melyet a Férfi, nyilvánvalóan saját, be nem látott/vallott szorongása okán, saját beszélő-racionalizáló énje és saját valósága közé épített fel.

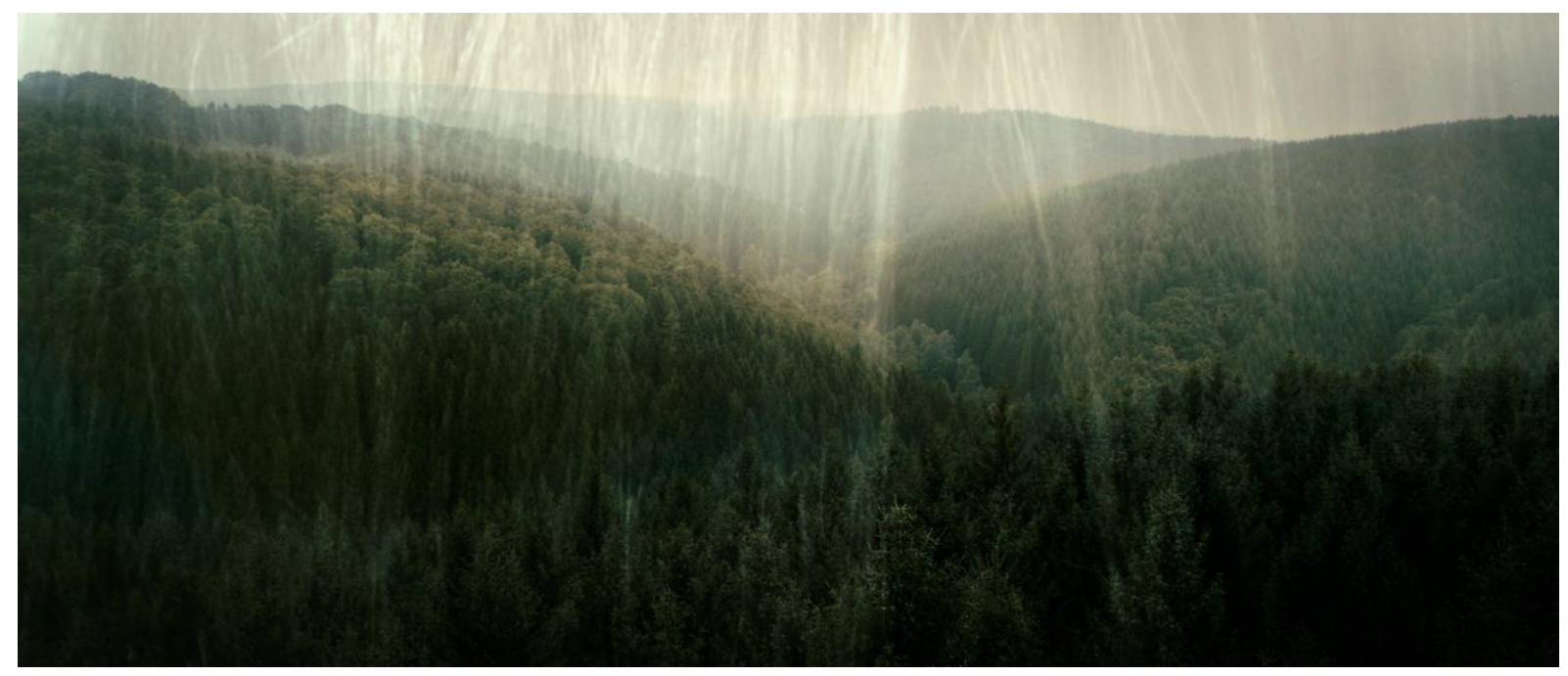

Mert mozzanatról mozzanatra bizonyosabb lehet benne a néző, hogy a filmbeli valóságnak egyre inkább a Nő válik ezoterikus ismerőjévé. Vagy talán pontosabb azt mondani, hogy ez a valóság egyre inkább a Nő melankolikus-allegorikus szemléletének az uralma alá kerül. Az Éden nevet viselő erdei házikóhoz tartó vonatút során a Férfi hipnózisszerü állapotba hozza a Nőt, előre, képzeletben bejáratja vele a házhoz vezető utat, majd felszólítja, kicsit ötletszerünek tünő módon, hogy feküdjön le a ház előtt a zöld fübe, majd váljon eggyé a zölddel. Ezután felébreszti a hipnózisból, és feltehetőleg biztatásképpen 
mondja neki, hogy végül is mindegy, mi fog történni ezután, a Nőnek már sikerült túljutnia a természettel kapcsolatos szorongásán, hiszen, mint kijelenti, amit az elme képes felfogni és elhinni, azt elérni is képes ("Remember: what the mind can conceive and believe it can achieve"). Ez is, természetesen, egy naiv-ironikus jóslatmozzanat: a film minden reáliája, beleértve a Férfi későbbi látomásait-álmait is, ezek után egyre nyilvánvalóbban a Nő átfogó allegorikus-melankolikus tekintetének érvényét igazolja majd vissza. Gyász, fájdalom, kétségbeesés (Grief, Pain, Despair): a bünbeeső természet egyre mélyrehatóbb, fokozódóan kaotikus és önkényes allegorizációjának a fázisait jelölik a film fejezetcímei. Az állatok: az őz, a róka, a holló a süllyedő fokozatok hírnökei. Álom és ébrenlét, delírium/illumináció és józanság már az első látomásos erdei állat, a halott őzgidát szülő és a testéből félig kilógó tetemmel riadtan elszökellö ünő megjelenésétől fogva szigorúan elválaszthatatlanná válik a film nyelvében: a kora újkori, reneszánsz és barokk allegorikus kifejezésmód legnemesebb hagyományaihoz hủen. Ezért válik igazán durva hatásúvá az a film eladdig felépített nyelvétől radikálisan eltérő naturalizmus, ahogyan a második és a harmadik fejezet lezáró részeiben az erőszakcselekmények és az öncsonkítás bemutatásra kerülnek. A naturalizmus azonban megtévesztő. Úgy gondolom, hogy ezek a jelenetek végül minden brutalitásukkal együtt visszaírhatóak a film allegorikus jelentéseinek körébe, jóllehet egyúttal éppen e jelentések tautologikus kiteljesítése révén, mikor a három koldus (Gyász, Fájdalom, Kétségbeesés; az őz, a róka és a holló konstellációja) égen és földön együtt van már, radikálisan fel is függesztik minden ilyen jelentésadás érvényét: ettől lesz bátran és kockázatosan átlátszó ennek a filmnek a konstrukciója; az erőszakos vagy véres jelenetek valóban, a szó legpregnánsabb értelmében kritikusak: az erőszak és az öncsonkítás ábrázolása a film szövetén több nyílt sebet okozó kritikai funkcióval bír. 


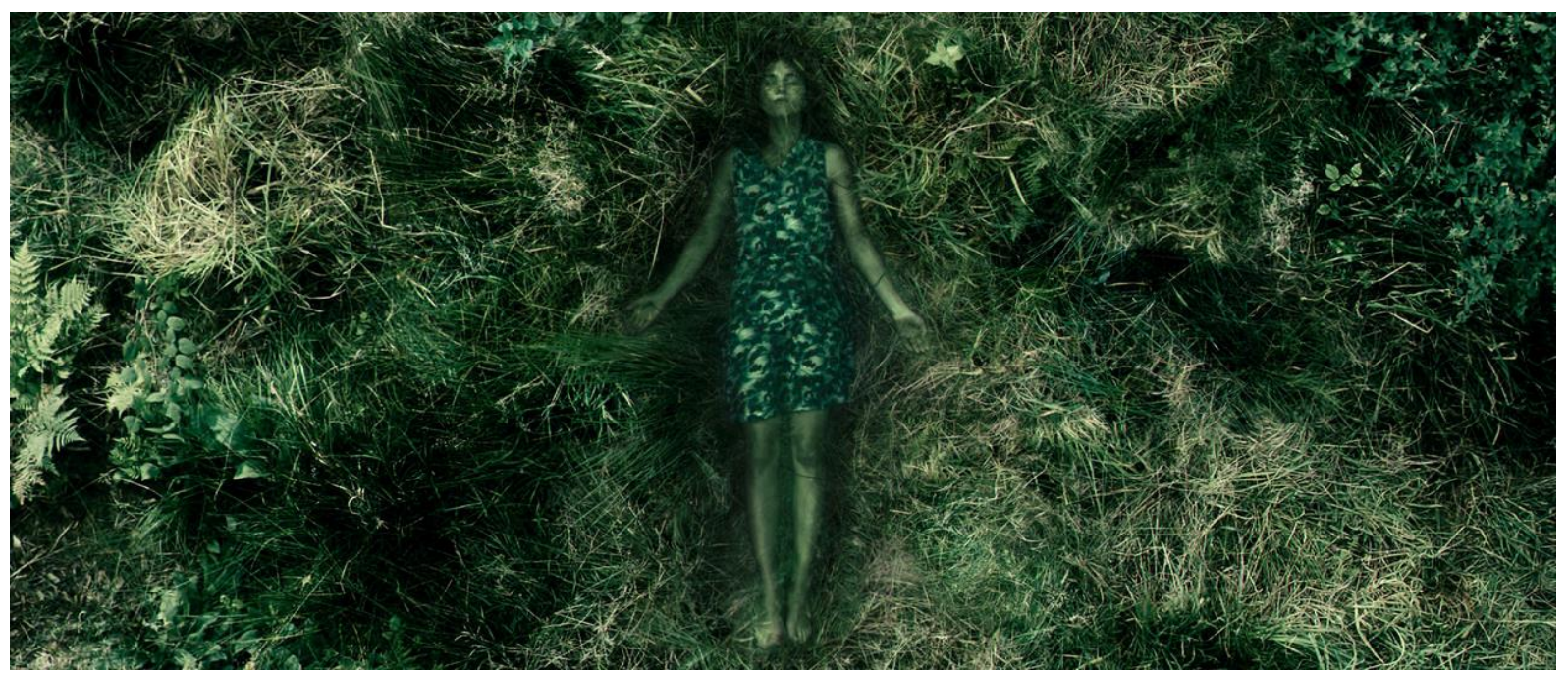

Ám minden funkciót megelőzően a nemi szervek elleni erőszakos támadás ábrázolásának olyan hatása van, amely a filmtörténetben teljesen példátlanul közelíti meg a közvetlen érzéki tapasztalás illúzióját. Kiváltképp a Nő öncsonkításának ábrázolása kelt ilyen közvetlen, sőt szinte közvetlenül fájdalmas hatást. Talán éppen azért, mert erre már valamiképpen számít a néző, és nem olyan hirtelen-váratlan, racionálisan előkészítetlenül, látszólag szenvedélyből történik, mint a Férfi merev nemi szervét szétroncsoló ütés a fahasábbal. A csikló lemetszése nyíltan előre megfontolt szándékkal történik. Az érzékiségtestiség egyik szélső pontján, a fájdalom totalitásában egyszerre fosztódik meg a szuperplánban mutatott, vért lövellő vagina minden szimbolizáció és allegorizáció lehetőségétől: puszta felmetszett élő hússá válik; ám éppen emiatt, a fájdalom testiséget szélső értékéig fokozó pillanata miatt egyúttal telítődik is minden szimbolikus és allegorikus energiával: egészen addig a pontig, amit a logika tautológiának mondana. A Prológus szimultán szeretkezés-haláleset képsorának hetedik vágóképében látjuk az erotikus örömszerzés elsődleges médiumaként szereplő, kopuláló nemi szerveket. Az érzéki örömszerzés szélső pontjától jutnak el ezek a nemi szervek a film inkognitóban lévő „,szereplőiként”, meg nem alkuvó következetességgel, az érzéki fájdalomszerzés szélső pontjáig. Ám természetesen az erósz ebben a filmben mindenütt, rejtettebben vagy 
nyíltabban, csak erósz thanatoszként nyilvánulhat meg. A nyitó képsor még külsőleg, a szeretkező szülők és meghaló gyermekük szimultán képsorán keresztül mutatja be az érzéki öröm ájulatának, a testiség egyik szélsőséges tapasztalatának és a beteljesülésként megélt halál tapasztalatának a közeli rokonságát. Az ablakból kizuhanó gyermeket szűz fehér hó nyeli magába. A nemi szervek fájdalmas megsebzése már a testiség másik végletén a fájdalom szélsőséges megtapasztalását és a reménytelen elpusztulás felett érzett szomorúság és kétségbeesés tapasztalatát hozza belső fedésbe, azonosítja egymással. Ez a Nő tanítása a Férfi számára, aki a szélsőséges testi fájdalom érzéki megtapasztalásának híján nem volt képes a gyász megtapasztalására sem. "You're indifferent whether your child is alive or dead", mondja még az erdei házba való utazás előtti beszélgetés során a Nő a Férfinak, és ez az egyik olyan vád, amelyet a Férfi végül is válasz nélkül hagy, másról kezd el beszélni.

Az Antikrisztus egy beavatás története. A negatív kinyilatkoztatás forrása és tárgya a filmbeli természet, a beavatás médiuma a Nő, a beavatás alanya pedig a Férfin keresztül a néző. A beavatás eredménye azonban nem egy ezoterikus tudás birtokbavétele, hanem inkább egy utalás vagy intés, mely minden ezoterikus-kisajátító igényü tudáskomplexum és gondolkodásbeli sematizmus eredendően konstruktív voltára emlékezteti a nézőt. Mintha egy boszorkány-beavatást és egy autodafét egyidejűleg látnánk átvilágítva: a lezárásban a boszorkány-narratívát beteljesítő, máglyaként funkcionáló farakás már a Nő legelső, képzeletbeli-hipnotizált látogatásakor ott vár áldozatára és a megelevenítő szikrára az erdei ház elött.

Van néhány pont, amelyeknél a beavatás-narratíva nyíltan ironikus távlatba kerül. Ezek során szemérmetlenül meztelen lesz a konstrukció. A film világának tézisszerü, ám mégis 
kétértelmű tanítását kinyilatkoztató rókát színre vivő jelenet például ilyen. A második fejezet (Pain (Chaos Reigns)) végén a páfrányokkal fedett tisztáson rezegni kezd az egyik növény szára, a magára maradt Férfi gyanútlanul közeledik hozzá, akárcsak korábban az őz felé, a szél is feltámad, a férfi lehajol és félrehajtja a rezgő leveles szárat, gyors és hatásvadász vágás után egy csapzott róka ugrik fel a levelek közül fenyegetőleg fellépve, majd lassított felvételen azt látjuk, ahogy a róka saját beleit vagy magzatát tépi ki magából; végül az állat megszólal, kinyilatkoztat a Férfit játszó színész (Willem Dafoe) eltorzított hangján: “Chaos reigns”. Természetesen ennek a jelenetnek is van jóslat-funkciója: a Nő később bekövetkező öncsonkítására utal előre. De közvetlen hatásában számomra elsősorban groteszk-komikus érzést keltő volt. Már legelső megtekintéskor hangosan fel kellett nevetnem ez alatt a jelenet alatt, bár utólagos reflexióm során nem voltam bizonyos abban, hogy nevetésem minek is szólt valójában: a kétségkívül müfaji paródiaként is ható beszélő rókának vagy saját helyzetemnek, az allegorikus értelmezésekbe kényszerített nézőének, akin éppen most nevet a film rendezője.

Nem a nevetségességgé válástól való félelem az elsődleges oka azonban annak, hogy ezen a ponton felfüggesztem a film motívumkörének elemzését. A film epikai motívumainak elemzéséből más irányokba is termékenyen el lehet indulni, elég csak az erósz thanatosz toposzának egészen eredeti, Georges Bataille gondolatait idéző megközelítésére gondolni, vagy a boszorkányság-narratíva ambivalens megidézésére itt; számomra jelenleg az volt a fontos, hogy a bünképződés tudatos-tudattalan kontinuumának főbb elemeit vegyem sorra és értelmezzem. A soron következő, dolgozatomat lezáró epilógus annyiban egészíti ki ezt a gondolatmenetet, amennyiben egy olyan bün-megközelítés alapmozzanatait igyekszik számba venni, amelynek integrálása az Antikrisztus címü film feltehetőleg leginkább gyümölcsöző befogadását is szavatolhatja. 
Epilógus. „Eredendö” bün/szabadság: Søren Kierkegaard szorongásértelmezésének adalékai Walter Benjamin sors- és nyelvfogalmához

A szorongás fogalma azért ad alapvetően fontos szempontokat a sors fogalmának vizsgálatakor, mert a szorongás pszichológiai diszpozíciója valamiképpen előhívja a sorsot. Ezt az alapvető összefüggést ezen a ponton még nem tudom pontosabban körülírni; a szorongás által uralt léleknél mindenesetre senki sem érzi áthatóbbnak az örök visszatérést. Minél jobban uralja őt a szorongás, és minél több reflexióval viszonyul intellektuálisan ehhez a szorongás által uralt állapothoz anélkül, hogy a belőle való kitörésre bármilyen lehetőséget látna, annál inkább a sors kezét érzi minden életmegnyilvánuláson, amely öt körülveszi, vagy amelyek benne lezajlanak. Az Antikrisztus női szereplöje ennek az állapotnak egyszerre mutatja fel szélsőséges változatát, és egyben a legrombolóbb kritikájának lehetöségét is.

Az eredendő bün (Erbsünde) megfoghatatlan fogalmát járja körül Søren Kierkegaardnak A szorongás fogalma ${ }^{108}$ című írása, mely alcíme szerint „egyszerü pszichológiai irányú vizsgálódás az eredendő bün dogmatikai problémájával kapcsolatban”.

\footnotetext{
${ }^{108}$ Søren Kierkegaard: A szorongás fogalma. Ford. Rácz Péter. Göncöl Kiadó, 1993. Mivel a dán nyelvet egyáltalán nem értem, ezért a német fordítást fogom ebben az epilógusban kontrollként használni. Kérem az olvasót, legyen megértéssel a részleges filológiai pontatlanság miatt. Søren Kierkegaard: Der Begriff Angst. Aus
} 
A bün elsősorban megmagyarázhatatlansága okán „dogmatikai probléma”: vagyis előfeltételezett, hipotetikus, és egyszersmind axiomatikus fogalom. Ez a meg nem szüntethető megmagyarázhatatlanság, posztuláltság az eredendő bűn „dogmájának” lényegi motívuma. A szorongás fogalma nem is a bün magyarázatára hivatott, hanem azt a strukturális vonatkozásban utolsó pszichológiai megközelítést írja körül, amely az eredendő bűn eredetére utal vissza és a bün megmagyarázhatatlan minőségi ugrását, minden egyes újabb individuum révén történő újbóli megjelenését vetíti előre (a szükséges változtatásokkal ugyanez lesz a feladata a kétségbeesés fogalmának is $A$ halálos betegség kontextusában: szorongás és kétségbeesés hasonló kontinuumot alkot az Antikrisztus című film cselekményvezetésének pszichológiai-allegorikus rétegződésében, melyre a fejezetcímek nyíltan utalnak is. Bün és kétségbeesés viszonya $A$ halálos betegség címü könyvben végső soron egyfajta problematikus azonosság).

A szorongás fogalma címü könyv bevezetéséből megtudjuk, hogy amennyiben az értelem számára próbálunk találni valamilyen megragadható magyarázatot a bün keletkezésére vonatkozóan, annyiban csakis a megfigyelő pszichológiai megközelítés jöhet számításba, mely az egyénben figyeli meg a bün prediszpozíciójának (a szorongásnak) lehetősége szerint végtelen gazdagságát. Fontos már itt megjegyezni, hogy az egyénre koncentrált megfigyelés nem jelentheti azt, hogy a társadalmi és történelmi aspektusról egy pillanatra is elfeledkezünk. Az elvont fogalmi gondolkodás és az, amit Kierkegaard formális logikának nevez (ez leginkább egy hegeliánus, és nem is feltétlenül hegeli logika volna intuícióm szerint) önmagában egyként lepattan a bünfogalomról. Mert pszichológiai értelemben vak az ilyen gondolkodás. Inkább nyomozásról, semmint bizonyításról, felderítésről, netán felfedezésről van szó. Ez egyébként is az adekvát pszichológiai 
megfigyelés ismérve. A gyanúsított, a bün „fogalma” az utolsó pillanatban mindig megszökik: az igazi nyomozó minden rezignációja ellenére viszont mégis mindig megőrzi a nyomok célravezetőségébe vetett hitét. Az etika illetékes igazán a bün következményeinek elemzésére, de csak annyiban, amennyiben „dogmatikailag” előfeltételezi az eredendő bünt (és nem „megmagyarázza”). A pszichológia pedig leírja, bemutatja a „hajlamosító előfeltevést”. „[A] maradandó állapot [Das Bleibende], amelyből a bün folyamatosan keletkezik, mégpedig nem szükségszerüen (hiszen a szükségszerü keletkezés: állapot, mint például a növények egész története [die gesamte Pflanzengeschichte] állapot), hanem szabadon; ez a maradandó, ez a hajlamosító előfeltevés [die disponierende Voraussetzung], a bün reális lehetősége - ez a pszichológia érdeklődésének tárgya. Ami a pszichológiát foglalkoztathatja és amivel a pszichológia foglalkozhat, az az, hogyan keletkezhet a bün, nem pedig az, hogy keletkezik [wie die Sünde entsteht, nicht daß sie entsteht]."109

Kierkegaard óva int attól, hogy a Biblia teremtéstörténetét mítosznak tekintsük. Bár nem teszi nyíltan evidenssé, hogy akkor hogyan is kellene olvasni, de gondolatmenete világosan megmutatja, hogy allegorikus jelentéssürítésként olvassa és értelmezi a Genezist. „A Genezis első bủnről szóló elbeszélését - különösen korunkban - mítosznak tekintik [wie ein Mythos betrachtet], ami elég könnyelmü dolog. Ennek jó oka van: ugyanis az, amivel helyettesítették, éppen egy mítosz volt, ráadásul balga [schlechter] mítosz; hiszen ha az értelem mitikus dolgokra adja a fejét, abból ritkán születik más, mint szószátyárkodás [Geschwätz ${ }^{110}$ ]. Ama elbeszélés az egyetlen dialektikus és következetes értelmezés. Tulajdonképpen egész tartalma

\footnotetext{
${ }^{109}$ Søren Kierkegaard: A szorongás fogalma, 29. Der Begriff Angst, 27.

${ }^{110}$ A „fecsegés” (itt a fordításban: „,szószátyárkodás”; németül Geschwätz) olyan terminusértékű szó Kierkegaard számára, amelyre Walter Benjamin egy másik Kierkegaard-szöveg alapján hivatkozik nyelvfilozófiai tanulmányában. Később idézem is a kérdéses szöveghelyet.
} 
összefoglalható a következö mondatban: A bün valamely bün révén jelent meg a világon [Die Sünde kam durch eine Sünde in die Welt].”111

A teremtéstörténet tanúsága szerint első pillantásra mintha a bünbeesés, ez az eine Sünde lenne az ember első jelentős, említésre méltó cselekedete. A bűnbeesés előtt azonban már megadatott neki a megnevezés/megismerés, vagyis a szabadság egy mozzanata, ebből pedig világos, hogy a teremtéstörténet intenciói szerint a megismerés, a „tudás” nem azonos a bűnnel. A ,jó és rossz tudása” (az ítélet és az absztrakció lehetősége) a teremtés és a kinyilatkoztatás perspektívájából tehát semmis, érvénytelen, a teremtéstől elidegenedett tudás. Hiszen a teremtéstörténet Isten-cselekvője minden teremtéséről azt látja-tudja, hogy jó. A ,jó” és a „rossz” ebből a perspektívából nem fedhetők le egymás logikai ellentéteként; nem egyenrangúak származásukat tekintve; ám a ,jó és rossz tudásának” érvénytelen volta maga után vonja azt is, hogy ez a fajta tudás valójában mit sem tud a ,jóról”, arról a ,jóról”, mely a „rosszat” egy örök és misztikus retroakció révén nyomtalanul magába nyeli; ha a ,jó” megjelenését eme teoréma mentén a teremtett világ örök (esztétikai) objektivitásában látjuk (akár Bahtyint követve), úgy a „rosszat” az Isten képmására teremtett teremtmény végtelen (pszichológiai) szubjektivitásában pillanthatjuk meg. A bünt a keresztény dogmatika mégis „,eredendőnek”, néhol „eredetinek” nevezi; mintha valami kezdeti mozzanat volna, vagy mintha maga is valaminek a kezdete lenne. A megnevezésben/megismerésben, a szabadságnak e mozzanatában ugyanis potenciálisan jelen van ez a semmi egy nem szükségszerü, megmagyarázhatatlan „megkötöttség” révén: ,a szorongás nem a szükségesség [Notwendigkeit] elrendelése, de nem is a szabadságé, a szorongás megkötött szabadság [sie ist eine befangene Freiheit], ahol a szabadság önmagában nem szabad, hanem megkötött, mégpedig nem a szükségszerüségben [Notwendigkeit], hanem önnönmagában”112 - ez a pszichológia nyelvén szólva a szorongás, a dogmatika nyelvén szólva pedig az eredendő bűn

\footnotetext{
${ }^{111}$ Kierkegaard, i.m., 40. Der Begriff Angst, 38.

${ }^{112}$ Kierkegaard, i.m., 60. Der Begriff Angst, 59.
} 
következménye. Utóbbi terminus azonban már maga kicsit túlszalad a helyzeten azzal, hogy bevonja a bủnt - hiszen a bünbeesés strukturális értelemben „még” nem történt meg. A formális logika perspektívájából ugyan ami lehetőség szerint létezik, az ténylegesen létezik is (amiről nem lehet beszélni, arról pedig valóban csak hallgatni lehet, mint például a megoszthatatlan fájdalomról), mégsem lophatjuk be az eredendő bűnnek ebbe a dogmatikai előfeltevésébe a tényleges első bün megtörténtét mint szükségszerü következményt. Ez üres, történelmietlen absztrakció volna csupán, mely kiiktatná a döntés, a felelősség és a szabadság kategóriáit. Még a teremtéstörténet beszélője is pusztán addig merészkedik, ha szabad ilyen blaszfémikusan fogalmaznom, hogy a szimbólumok nyelvén rekonstruálja a konkrét, a legvégletesebben egyedi proto- és kvázi-döntési szituációt. És a teremtéstörténet beszélője nem játssza a mindentudó elbeszélőt, aki mintha jobban ismerné a történetet, mint Ádám és Éva. Jóllehet a szereplőkhöz való viszonyában letagadhatatlanul van némi nehezen megragadható bensőségesség.

Talán ne siessünk annyira „elöre”, mint amennyire azt a formális logika lendülete megengedné, haladjunk sorjában végig a fázisokon - javasolja Kierkegaard. Ezen a ponton, amíg a megismerésben/megnevezésben még csak potenciálisan van jelen a ,jó és rossz tudásának" kísértése, és a szabadságnak még megnevezetlen (mert valójában, végső soron megnevezhetetlen vagy megnevezésre nem méltó) árnyéka a bűn, még nem tételeződik a megismerés számára a történelem. A ,szabadság” ebben az állapotban nem tudatosul; és éppen ez az ártatlanság: a tudatlanság. A szabadság szellemi világának testi-lelki, „természeti” analogonja a következetes, reflexió nélküli alkat: az ártatlanság kristályos foglalata. Természeténél fogva minden jellem ártatlan: a komédia, pontosabban a komikus minőség mutatja ezt meg nekünk, ahogy Benjamin ezt néhány mondatban, főként Molière-re hivatkozva összefoglalja Sors és jellem címü rövid írása végén. Törékeny foglalat az alkat mindazonáltal. A reflexió-nélküliség mint kritérium azt jelenti, hogy az ártatlanság állapota 
független az ebben az állapotban elkövetett cselekedetek megítélésétôl: maga az ítélkezés lehetősége már tudatot, reflexiót, a bünről és szabadságról való akármilyen homályos tudást feltételez. „Az, hogy ha a tudatlanságot kívülről szemléljük, és a tudás felé látjuk meghatározottnak, olyasmi, ami a tudatlanságot egyáltalán nem érinti. [Daß man die Unwissenheit, wenn sie von außen betrachtet wird, in Hinblick auf Wissen bestimmt findet, das hat mit ihr selbst gar nichts zu tun.]" "113 Csakhogy ez a tudatlanság egyáltalán nem a nemiségre vonatkozik. A természeti ártatlanság tehát egyáltalán nem a szüzességet jelenti, még ha a banális és hétköznapi fogalomhasználat, a kereszténység egyik alapdogmájának a hatására, ez ellen a felismerés ellen is tanúskodik lépten-nyomon.

Az ártatlan alkat a maga „természetességében” és „,ártatlanságában” a gyermeken, az őrület bizonyos esetein, a szociálisan-nemileg deviánsnak minősülő-minősített eseteken, hovatovább a „,bünözők” némely típusán jóval nagyobb eredményességgel figyelhető meg és elemezhető, mint a „sikeresen” és „hasznosan” szocializált felnőtt polgáron (akit konvencionálisabb, általánosan elterjedt, és ezért nehezebben specializálható őrült tudat jellemez); Michel Foucault joggal mutatja be több helyütt is, hogy az emberről szóló pozitív/pozitivista tudományok, vagyis az emberről szóló rendszerezett-empirikus őrült tudatkomplexumok létrejöttében ezek a megismerés-területek, valamint a velük korrelatív társadalmi gyakorlatok, intézmények, épületek, laboratóriumok (iskolák, kórházak, elmegyógyintézetek, börtönök) játszották a fö, archeológiai jelentőségű szerepet. Az alkat „természetessége” (ezért az idézőjelezés) természetesen maga sem független a történelemtől még az újszülöttben sem.

Miután elégtelennek, nem kellőképpen dialektikusnak és rugalmatlannak találja a bünös (tiltottra irányuló) vágy (concupiscentia) történeti-dogmatikai fogalmát, mint az eredendő

\footnotetext{
${ }^{113}$ Kierkegaard, i. m., 47. Der Begriff Angst, 45. Fontos, hogy ezen a szöveghelyen nem Erkenntnis, hanem Wissen szerepel.
} 
bűnt túlságosan megmagyarázó pszichológiai leírást, Kierkegaard a szorongás fogalmát, mint az ,álmodó szellem” pszichológiai meghatározását vezeti be. Itt jelenik meg gondolkodásában a legerősebb dogmatika-kritikai mozzanat, és egyébként e mủvében, mely könyv a szerzőtől némileg szokatlanul nem-költői és nem-gördülékeny, ez a mozzanat mégis a leginkább poétikusnak tekinthető és logikailag legsérülékenyebb mozzanat is egyúttal. A tiltottra irányuló vágyból szükségszerüen, elkerülhetetlenül törne elő a bün; ez mitikus, sorsszerü (de egyszersmind a maga vaslogikáját követő), utólagos pszichológiai magyarázat. A szorongás által megkörnyékezett ártatlanság pont annyira kétértelmü, meghatározatlan, allegorikus jelentéssürítést hordozó álom-állapot, amelyből a bün „minőségi ugrással”, transzcendencia révén: kvázi döntés-szerủen lép elő, még ha kívülről sodródásnak látszhat is ez; mint ahogy az álomból félálomba, majd teljes ébrenlétbe tartó, legapróbb fokozatokra bontható átmenet sem moshatja teljesen el alvás és ébrenlét radikális különbségét.

Kierkegaard-nál a pszichológiai-filozófiai, traktátus-szerü tárgyalás természetének megfelelően inkább a dialektikus kétértelmüség észben tartása, semmint az allegorikus jelentésszórás kibontakoztatása kap elsőrendű szerepet. „Minden azon fordul meg, hogy a szorongás láthatóvá váljon [Daß die Angst zum Vorschein kommt, das ist der Kernpunkt des Ganzen]. Az ember a lelki és testi szintézise. De minden szintézis elképzelhetetlen, ha a kettő nem egyesül a harmadikban. Ez a harmadik a szellem. Az ártatlanságban az ember nemcsak állat, ha az egyáltalán, mert ha életének bármelyik pillanatában csupán állat lenne, soha nem válhatna belőle ember. A szellem tehát jelen van, de közvetlen, álmodó szellemként [als unmittelbarer, als träumender Geist]. Amennyiben viszont jelen van, bizonyos értelemben ellenséges hatalom [feindliche Macht], mert állandóan zavarja a test és lélek közötti kapcsolatot [Verhältnis], amely ugyan létezik [Bestand], de annyiban egyúttal mégsem létezik, hogy a létezését csak a szellemtől nyeri. Másrészt pedig jószándékú hatalom [freundliche Macht], amely éppenséggel meg akarja teremteni [konstituieren] e kapcsolatot. 
Mi tehát az ember viszonya [Verhältnis] ehhez a kétértelmü hatalomhoz [dieser zweideutigen Macht], hogyan viszonyul [verhält] a szellem önmagához és a feltételéhez? Szorongásként viszonyul hozzá [Er verhält sich als Angst]. A szellem nem szabadulhat meg önmagától; önmagát megragadni szintén nem képes, amíg önmagán kívül van; az ember a vegetatív világba sem merülhet, hiszen szellemiként van meghatározva; nem tud elmenekülni a szorongás elől, hiszen szereti; ámbár igazán szeretni sem tudja, hiszen menekül előle. Az ártatlanság tehát sarkított helyzetben van: tudatlanság, de nem állati durvaság [tierische Brutalität], hanem szellemileg meghatározott tudatlanság; amely viszont éppen szorongás, mert a tudatlansága a semmire vonatkozik. Nem ismer jót és rosszat stb.; a szorongásban a tudás teljes valósága mint a tudatlanság borzalmas semmije tükröződik vissza [Hier gibt es kein Wissen von Gut und Böse usw., sondern die ganze Wirklichkeit des Wissens projektiert sich in der Angst als ungeheures Nichts der Unwissenheit]."114

Ahogyan az alvajáró ébred fel, mikor a nevét hallja, úgy itt is elég egy (lényegében még érthetetlen) szónak elhangzania, hogy az ártatlanság álom-állapota önmaga valóságára ébredjen, és a szorongás tudatosuljon. A bünbeesés történetének és a bün fogalmának nyelvfilozófiai jelentősége elsőrendű; ez a belátás Kierkegaard-nál is több-kevesebb nyilvánvalósággal él. Annak oka, hogy egy másik idevágó és fontos szöveget idézek hosszabban ezúttal, az, hogy kifejtettebb formára jut benne a teremtéstörténet és a bünbeesés tárgyalásakor a nyelvi szempont. Walter Benjamin nyelvfilozófiai alapvetés-jellegü fiatalkori tanulmányára hivatkozom, amelyről már többször szó esett, és melynek címe $A$ nyelvröl általában és az ember nyelvéről. Remélhetőleg sikerül ennek révén azt is jeleznem, hogy hogyan illeszkedhet a Søren Kierkegaard elemzésében negatíve meghatározott szabadságfogalom Walter Benjamin megnevezésről és megismerésről kialakított

\footnotetext{
${ }^{114}$ Kierkegaard, i.m., 53-4. Der Begriff Angst, 52-3. Itt is Wissen szerepel az Erkenntnis helyett.
} 
elgondolásaihoz. Elöljáróban fontos megjegyezni, hogy a Walter Benjaminnál, és lényegében, kevésbé kifejtett formában, Kierkegaard-nál is munkáló nyelvfogalom kiindulását tekintve teológiai megalapozású. Ahogy Benjamin ebben a tanulmányban meg is jegyzi, ,az itt következő kifejtések alapelvüket tekintve annyiban követik a Bibliát, hogy bennük a nyelv végső, csakis kibontakozásában szemlélendő, megmagyarázhatatlan és misztikus valóságként van előfeltételezve."115 Joggal juthat eszünkbe erről a megjegyzésről, különösen a misztikus szóról, egy keletkezési idejét tekintve félelmetesen közeli munka, mégpedig Ludwig Wittgenstein Tractatus logico-philosophicusa. És kiinduló nyelvtapasztalatukban rokonok is ezek az írások. Annyiban azonban a két szöveg épp ellentétes irányban halad, amennyiben a Tractatus-ban a kimondhatatlanságé az utolsó szó, mely eredményt egy lehetetlen filozófiatörténeti képpel úgy írhatnánk le, mint egy gnosztikus naivitását elveszítő, Kant kritikáin és Frege logikáján iskolázott Jakob Böhme agnosztikus miszticizmusát; míg Benjamin írásában bizonyos értelemben épp ellenkezőleg, a szellemi lényeg és a kimondhatóság közötti fordított arányosság felfüggesztődik, sőt megfordul, és ezt a név és a kinyilatkoztatás fogalmának a nyelvfilozófia centrumába való beemelésével foganatosítja a szerző: „Minden nyelvi képződményen belül ott zajlik a kimondott és kimondható vitája a kimondhatatlannal és ki-nem-mondottal [Innerhalb aller sprachlichen Gestaltung waltet der Widerstreit des Ausgesprochenen und Aussprechlichen mit dem Unaussprechlichen und Unausgesprochenen]. E vitát szemlélve a kimondhatatlan perspektívájában ugyanakkor a végső szellemi lényeget [das letzte geistige Wesen] látjuk. Mármost világos, hogy a szellemi és a nyelvi lényeg azonosításában [Gleichsetzung] elvitatjuk a kettő közötti fordított arányosság viszonyát. Hiszen itt így szól a tézis: minél mélyebb, vagyis minél létezőbb és

\footnotetext{
${ }^{115}$ Walter Benjamin: „A nyelvről általában és az ember nyelvéről.” Ford. Szabó Csaba. In WB: „A szirének hallgatása”. Válogatott írások. Budapest, Osiris, 2001. 14.o. WB: GS 2, 147. Vö. Kierkegaard egy jegyzetével: „Ha közbe akarnák vetni, hogy nyitva maradt az a kérdés: hogyan tanult meg az első ember beszélni, akkor elismerném a kérdés jogosságát, de megjegyezném azt is, hogy ez kívül esik vizsgálódásunk területén. Ám azt se higgyék, hogy kitérő válaszommal az újabb filozófiai szokás szerint egyúttal azt a látszatot is akarnám kelteni, mintha más alkalommal meg tudnám válaszolni a kérdést. Annyi azonban biztos: nem lehet azt állítani, hogy az ember maga találta volna föl a nyelvet." Søren Kierkegaard, i.m., 58.o.
} 
valóságosabb a szellem, annál kimondhatóbb és kimondottabb, ahogyan éppen eme azonosítás értelmében áll, hogy a szellem és a nyelv közötti vonatkozást teljességgel egyértelművé tegyük, úgy, hogy a nyelvileg leglétezőbb, vagyis legrögzítettebb kifejezés, a nyelvileg legpregnánsabb és legkevésbé megingatható, egyszóval: a legkimondottabb, ugyanakkor a tisztán szellemi [wie es denn eben im Sinne diese Gleichsetzung liegt, die Beziehung zwischen Geist und Sprache zur schlechthin eindeutigen zu machen, so daß der sprachlich existenteste, $d$. h. fixierteste Ausdruck, das sprachlich Prägnanteste und Unverrückbarste, mit einem Wort: das Ausgesprochenste zugleich das reine Geistige ist]."116

A tanulmány címének is megfelelően Benjaminnál nem egy metaforikus áttétel révén, hanem közvetlen megismerő értelemben kiterjesztett nyelvfogalom a kiindulópont: „Nincs olyan történés vagy dolog, sem az eleven, sem az élettelen természetben, aminek ne volna bizonyos módon része a nyelvben, hiszen minden számára lényegi, hogy szellemi tartalmát közlön megosztja [denn es ist jedem wesentlich, seinen geistigen Inhalt mitzuteilen]. A >>nyelv<< szó azonban ilyetén használatban egyáltalán nem metafora. Hiszen teljes tartalmas megismerés az [Denn es ist eine volle inhaltliche Erkenntnis], hogy nem tudunk elképzelni semmit, ami szellemi lényegét ne osztaná meg, ne közölné a kifejezésben; a nagyobb vagy csekélyebb tudatfok, mellyel látszólag (vagy valóságosan) kötődik egybe a közlés, mit sem változtathat azon, hogy a nyelv teljes hiányát [völlige Abwesenheit der Sprache] semmiben sem tudjuk elképzelni." ${ }^{117}$ A dolgok (a természet) néma, névtelen nyelve, a matéria mágikus közössége mint az ő(ke)t létrehívó isteni teremtő szó zörejszerü (néma) reziduuma kifejezi magát az embernek, aki a maga hangzó-megismerő nyelvére fordítja, és a fordítás hatékonyságának arányában megismeri-megnevezi ő(ke)t. A fordítások sokféleségével adva van az emberi nyelvek sokasága, a bábeli nyelvzavar és a megismerés tökéletlensége. Ez Benjamin gondolatmenete szerint a bünbeesés eredménye. „Hogy ugyanis a paradicsom

\footnotetext{
${ }^{116}$ Walter Benjamin, „A nyelvröl...”, 12-13. WB: GS 2, 146.

117 Benjamin: „A nyelvröl...”, 7. WB: GS 2, 140-141.
} 
nyelve tökéletesen megismerő [vollkommen erkennend] volt, azt a megismerés fájának ottléte sem képes elleplezni [verhehlen]. E fának almái állítólag annak megismerését adják, hogy mi jó és rossz. Isten azonban már a hetedik napon a teremtés szavaival megismert. És látá Isten, hogy jó. Az a megismerés, amire a kígyó csábít, vagyis annak tudása, hogy mi jó és rossz: névtelen [Die Erkenntnis, zu der die Schlange verführt, das Wissen, was gut sei und böse, ist namenlos]. E tudás a legmélyebb értelemben semmis [nichtig], és éppen e tudás maga az egyetlen rossz, amelyet a paradicsomi állapot ismer. A jóról és rosszról való tudás elhagyja a nevet, ez kívülről jövő megismerés, a teremtő szó nem teremtő utánzása [die unschöpferische Nachahmung des schaffenden Wortes]. A név ebben a megismerésben kilép önmagából: a bünbeesés az emberi szó születésének órája, mely szóban a név már nem sértetlenül élt, olyan szó, amely a név-nyelvből, a megismerőből, s mondhatjuk: az immanens saját mágiából kilépett, hogy kifejezetten, mintegy kívülről, váljon mágikussá. A szónak valamit kell közölnie (önmagán kívül még). Ez valóban a nyelvszellem bünbeesése. [Das Wort soll etwas mitteilen (außer sich selbst). Das ist wirklich der Sündenfall des Sprachgeistes.] [...] A dolgok megismerése a névben nyugszik, a jó és rossz megismerése azonban $>>$ fecsegés $<<$ $[>>$ Geschwätz $<<]$ abban a mély értelemben, ahogyan Kierkegaard fogja fel ezt a szót, és csupán egyetlen megtisztulást és felemelkedést ismer, aminek aztán a fecsegő ember [der geschwätzige Mensch], a bünös is alárendeltetik: az ítélkezést [das Gericht]. Az ítélkező szó számára persze közvetlen a jó és rossz megismerése. Mágiája más, mint a névé, de nem kevésbé mágia. Ez az ítélkező szó taszítja ki az első embereket a paradicsomból; ők maguk excitálták az ítélkező szót, örök törvényt követve, mely szerint ez az ítélkező szó önmaga felkeltését mint az egyetlen, legmélyebb bünt bünteti meg - és várja el. A bünbeesésben, amikor a név örök tisztaságát [die ewige Reinheit] megsértették, emelkedett ki az ítélkező szó, az ítélet szigorúbb tisztasága [die strengere Reinheit]. A nyelv lényegösszefüggésére [Wesenszusammenhang] vonatkozóan a bünbeesésnek háromszoros jelentése van (hogy 
további jelentését itt ne említsük). Az ember azzal, hogy a név tiszta nyelvéből kilép, a nyelvet eszközzé teszi (nevezetesen egy nem őhozzá mért megismerés eszközévé) [macht er die Sprache zum Mittel (nämlich einer ihm unangemessenen Erkenntnis)], ezzel egy részében mindenesetre puszta jellé is [bloßen Zeichen]; és ennek következménye később a nyelvek többessé válása. A második jelentés az, hogy most a bűnbeesésből, a név benne megsértett közvetlenségének helyreállításaként [Restitution], egy új mágia, az ítélet mágiája emelkedik ki, amely már nem nyugszik boldogon önmagában. A harmadik jelentés - amit talán sejteni merészelhetünk - az volna, hogy az absztrakciónak mint a nyelvszellem egyik képességének eredetét is a bünbeesésben kell keresni."

Első pillantásra itt termékeny ellentmondásba kerül a paradicsomi nyelvet „tökéletes megismeréssel” felruházó benjamini gondolatmenet Kierkegaard értelmezésével, aki, következetesen ragaszkodva ahhoz a tételhez, miszerint az ártatlanság tudatlanság, a jó és rossz tudásának megtiltásáról szóló szöveghelyet közvetlenebbül pszichológiai keretben a következőképpen kommentálja: „Bár még létezik az ártatlanság, de elég egy szónak elhangzania, és a tudatlanság koncentrálódik. Érteni ugyan nem érti az ártatlanság ezt a szót, a szorongás azonban mintha meglelte volna első zsákmányát: a semmi helyett egy rejtélyes szót [sie hat anstelle des Nichts ein rätselhaftes Wort bekommen]. Ha tehát a Genezisben az áll, hogy Isten így szólt Ádámhoz: >>de a jó és gonosz tudásának fájáról [Baum der Erkenntnis des Guten und Bösen], arról ne egyél <<, akkor magától értetődik, hogy Ádám tulajdonképpen nem értette meg a mondatot; hiszen hogyan értené meg a jó és a gonosz közti különbséget, mikor ez a megkülönböztetés csak azután lehetséges, miután megkóstolta a gyümölcsöt [denn wie sollte er den Unterschied zwischen Gutem und Bösem verstehen, wo der sich doch erst mit dem Genuß herausstellte]."119 Ugyan a „tudás fája” a német Kierkegaard-szövegben, Benjaminéhoz hasonlóan, „,megismerés fájaként” (Baum der Erkenntnis) szerepel, a fent

\footnotetext{
${ }^{118}$ Walter Benjamin: „A nyelvröl...” 18-19. WB: GS 2, 152-54.

${ }^{119}$ Søren Kierkegaard, i.m., 54. Der Begriff Angst, 53.
} 
említett ellentmondás mégis akkor válik valóban termékennyé, ha igyekszünk elgondolható különbséget tenni a megismerés és a tudás/tudatlanság között. Amikor Benjamin azt írja, hogy a „dolgok megismerése a névben nyugszik”, akkor értelemszerüen arra a névre gondol, amellyel/amelyben Isten létre hívta dolgokat: vagyis az axiomatikus/posztulált teremtő szóra. Az ebben az értelemben vett megismerés magukban a dolgokban/nevekben nyugszik: ez a megismerés Isten teremtő nyelvének a tanulmányozása. Ez a legradikálisabb értelemben vett tapasztalat-fogalom lehetőségét nyitja meg. ${ }^{120}$ És ez „,nemcsak a némának fordítása a hangzóra: a névtelen fordítása is a névbe" ${ }^{\text {"121 }}$. Ebben az elméleti-gyakorlati keretben minden név a terminus legsajátabb értelmében vett tulajdonnév: az absztrakciós képességből fakadó köznevek elvesztik (pontosabban: „,még” el sem nyerték) érvényüket. Ehhez képest a jóról és rosszról való tudás „kívülről” jövő megismerés, mely nem magukban a dolgokban/nevekben jön létre, hanem egy elvonatkoztatott mérce felöl megítéli/elítéli öket. Ez az ítélkező/absztraháló tudás indítja el a köznevesítést. A „bünbeesett nyelvszellemben” tehát együtt lelhető fel a jog és az absztrakt okoskodás eredete - minden olyan kívülről jövő tudás eredete, mely nem magukban a dolgokban/nevekben gyökerezik.

A „bünbeesett nyelvszellem” állapotát strukturálisan megelőző állapot, amelyet Kierkegaard szellemében a szorongó nyelvszellem állapotának nevezhetünk, még nem tud tehát ítéletről és absztrakcióról, de a bibliai elbeszélés sugalmazása szerint a tilalom és a büntetés révén sejtelme van róluk. A szorongó-ártatlan nyelvszellem Benjamin szavaival a „tökéletesen megismerő”, hiszen még mintegy belül van Isten teremtő nyelvén, és nem

\footnotetext{
${ }^{120}$ Ennek a megismeréssel minden ponton korreláló tapasztalat-fogalomnak a kidolgozása volna az eljövendő filozófia programja. Vö.: Walter Benjamin: „Az eljövendő filozófia programjáról.” Ford. Bence György. In WB: Angelus Novus. 5-23. „A tapasztalat a megismerés egységes és kontinuus sokrétüsége.” „Erfahrung ist die einheitliche und kontinuierliche Mannigfaltigkeit der Erkenntnis.” WB: „Über das Programm der kommenden Philosophie". GS 2, 168.

${ }^{121}$ Walter Benjamin: „A nyelvröl...” 17. „Die Übersetzung der Sprache der Dinge in die des Menschen ist nicht nur Übersetzung des Stummen in das Lauthafte, sie ist die übersetzung des Namenlosen in den Namen." WB, GS 2, 151 .
} 
kívülről próbálja azt utánozni ${ }^{122}$; e közvetlenül megismerő nyelvszellem immanens mágiája azonban sérülékeny immanencia. Ezt a felismerést tapasztalati-pszichológiai területen a szorongás fogalma fedi. Pontosan jelzi továbbá ezt a sérülékenységet a teremtéstörténetnek az a gondolkodást inspiráló következetlensége, mely szerint a jóról és rosszról még nem tudó emberhez kívülről szól a jó és rossz tudását tiltó parancs, valamint hogy a halálról még meg nem bizonyosodó, egészen pontosan a halál elkerülhetetlenségéről még meg nem bizonyosodó emberhez ugyancsak kívülről szól a halálbüntetést kilátásba helyező ítélet. Egy következetesen és ,ártatlanul” racionalizáló olvasat ebből a mozzanatból kiindulva egy teremtményeivel gonosz-érzéketlen módon kísérletező demiurgoszhoz juthat el. Az Antikrisztus-filmbeli teremtés, miután egyre nyilvánvalóbban alárendelődik a Nő szubjektívmelankolikus-allegorikus szemléletének, ezt a gonosz demiurgoszi aspektust erős, sugalmazott lehetőségként mindvégig fenntartja. Kierkegaard két helyütt is kitér könyvében erre a problémára. Az elsőként idézésre kerülő szövegrész már-már a pökhendiséget súroló frivol könnyedsége ne tévesszen meg bennünket; Kierkegaard kissé odavetettnek tünő megjegyzéseit Benjamin fentebb megidézett, pallérozottabban kifejtett nyelvfogalmából kiindulva megalapozottnak gondolhatjuk: „A tilalom és a büntetés hangja kívülről jött, ami néhány gondolkodónak természetesen gyötrelmeket okozott [Ich habe das Verbot und die Stimme der Strafe von außen kommen lassen. Damit hat sich natürlich so mancher Denker gequält]. Az ilyen nehézségen azonban legfeljebb csak nevetni szabad. Az ártatlanság jól és könnyen beszél, hiszen a nyelv révén birtokában van az összes szellemi kifejezésnek [Die Unschuld kann ja sehr wohl sprechen und besitzt insofern in der Sprache den Ausdruck für alles Geistige]. Ennyiben csak azt kell föltételezni, hogy Ádám önmagával beszélt. Így feloldódik az elbeszélésnek az a tökéletlensége, hogy valaki más beszél Ádámhoz, és ő nem érti. Abból, hogy Ádám tudott beszélni, mélyebb értelemben nem következik az, hogy meg is

\footnotetext{
${ }^{122}$ Ezzel a gondolattal termékenyen cseng össze az a kitérő Kierkegaard-nál, melyben Mefisztó figuráját mint lényegében mimikus alkatot mutatja be: Kierkegaard, i.m., 153-4.
} 
értette a neki mondottakat. Ez mindenekelött a jó és gonosz közti különbségre vonatkozik; hiszen ez a különbség létezik ugyan a nyelvben, de csak a szabadságra vonatkozik [Dies gilt vor allem für den Unterschied von Gut und Böse, den die Sprache zwar kennt, den es jedoch nur für die Freiheit gibt]. Az ártatlanság jól ki tudja fejezni ezt a különbséget, de ez a különbség nem neki szól... [Obwohl die Unschuld diesen Unterschied aussprechen kann, besteht er für sie nicht...]”123 Valamint: „Az elbeszélés ama fogyatékosságát [Mangel], hogy vajon kinek juthatna eszébe olyasmit mondani Ádámnak, amit az nem képes megérteni, kiküszöböljük, ha belegondolunk abba, hogy a beszélö maga a nyelv [der Sprechende die Sprache ist], és ilyetén módon Ádám az, aki beszél."124

„A beszélő maga a nyelv”. „A szorongás megkötött szabadság”. Paradoxonhoz jut az a gondolkodó, aki következetesen és kompromisszummentesen gondolkodik el a bün elgondolhatatlan fogalmától. És egyébként ezen és még néhány hasonló ponton már fennáll a túlmagyarázás veszélye, még ha igyekszik is elkerülni az ember az „ártatlanul” racionalizáló olvasás zsákutcáit. Ez a paradoxon azonban nem előre letétben tartott kiindulás, hanem eredmény, és ez hatalmas különbség: ez a különbség választja el az ilyen, megoldás-szerü paradoxont a közvetlenebb hatást keltő aforisztikus-lapidáris vagy éppen böbeszédủen fecsegő szofisztikától, amely az elgondolhatatlanságot alaptőkeként használva gyártja le bombasztikusnál bombasztikusabb, rejtélyesnél rejtélyesebb, vagy éppen az objektívnél is objektívebb kifejezéseit. „A szellemi és a nyelvi lényeg, amelyben az előbbi közöl, megoszt az e két lényeg közötti megkülönböztetés a legeredendőbb különbségtevés egy nyelvelméleti vizsgálódásban, és e különbség oly kétségtelennek látszik, hogy sokkal inkább a szellemi és a nyelvi lényeg közötti oly gyakran megállapított azonosság az a mély és felfoghatatlan paradoxon, melynek kifejezését a $\lambda o ́ \gamma o \varsigma$ szó kettős értelmében [Doppelsinn] találták meg.

\footnotetext{
123 i.m., 55-6. Das Begriff Angst, 54-5.

124 i.m., 57-8. Das Begriff Angst, 56-7.
} 
Mégis a nyelvelmélet centrumában van a helye ennek a paradoxonnak mint megoldásnak, ám paradoxon marad, és megoldhatatlan ott, ahol kezdetként áll. [Dennoch hat diese Paradoxie als Lösung ihre Stelle im Zentrum der Sprachtheorie, bleibt aber Paradoxie und da unlösbar, wo sie am Anfang steht.]"125 Walter Benjamin nyelvfilozófiájában, amely utólagosan alapozza meg Kierkegaard bünnel kapcsolatos gondolatait, e paradox megoldás, mint láttuk, a szellemi és nyelvi lényeg közötti fordított arányosság megfordításában jut érvényre. Ehhez mindkettejüknek el kell jutniuk a kinyilatkoztatás fogalmához, a szellemi és nyelvi lényeg paradox azonosságához, és így egy lényegét tekintve teológiai nyelvfogalomhoz is.

$* * *$

Lezárás előtti utolsó kitérőként egy a dolgozat eddigi menete során még meg nem szólaló hangot idézek fel, az ifjabb Vázsonyi Vilmosét. Ebben a rögtönzött esszéisztikus hatást keltő passzusban a beszélő egészen széles attitűd- és jelenségskáláját, időnként kissé mitikusnak és kaotikusnak tetsző összekeveredését mutatja fel annak, amit az Epilógusban áttekintettek nyomán naiv-szorongó-ártatlan és bünbeeső-szorongó-szabad nyelvszellemnek nevezhetnénk.

„Meg egyáltalában, Európa tele van gyönyörü dolgokkal. És ez euforizálja az embert, hogy ettől az életnek célja és értelme van. Nézed ezt, Mozartot vagy Bachot hallgatsz, és akkor minden más. Akkor az az érzésed, mintha nem is lett volna Soa. Akkor az az érzésed, hogy a szépséggel fel tudod függeszteni az egésznek a borzalmát. Ez valami nagyon furcsa dolog, nálam többféle módon létezik.

${ }^{125}$ Benjamin: „A nyelvröl...” 8. WB: GS 2, 141-2. 
Az egyik, amikor valóban elkap a szépségnek ez a fajta öröme. Lehet zenehallgatás közben is, nem számít, ha rossz a rádió, Bach, Mozart, Schubert. Lehet esztétikai-művészeti kinyilatkoztatás, és lehet a lányok szépsége. Ez a három dolog, ami miatt az ember él. Mert ez is, a lányok szépsége is felfüggeszti a Soát. Az is olyan, hogy akkor elmúlik bizonyos értelemben az egész. Nem múlik el, énbennem továbbra is megvan, de kint nem az van addig, amíg a szépség ideig-óráig ellentételezi, ha tetszik, a barbárságot. Akkor ez az én számomra, ha nem is megváltást, de provizórikusan felejtést hoz. Ez azt is jelenti, hogy az ember elfelejti a saját testét. Mert a számomra a Soa, az a test. Testiség a szónak a rossz értelmében. Míg az ejakulációban, az eksztázisban, a csodálatban és a szépség örömében kiszabadulsz a börtöntestből, a szoma-szémából. Valahol asztráltestté változol. És ez az eksztázis azt az élményt adja, amit Ágoston örökkévalóságnak mond. Az nem sok idő, hanem az idő teljes hiánya, az időfogalom nemléte. És csak az időfogalom nemlétével tudsz kilépni a történelemből. Az esztétikán keresztül, időnként. És akkor az öröklétben vagy, és akkor nincs Soa. Akkor csak te vagy halandó és veszendő, de valahol valami mást kapsz. Mert nyilvánvaló, hogy ha ilyen szépséget látsz, akkor az univerzum egy percre rendben van. Ami azt is mutatja, hogy a Soa most már állandóan itt van."126

A bünfogalom sorsfogalommal kapcsolatos müvészetfilozófiai és pszichológiai kritikai aspektusait a dolgozat V. fejezete és az Epilógus vette számba. Ezek után egy sorsvonatkozásoktól függetlenített, megszabadított bünfogalom kidolgozása lehetne a feladat, amely a szabadság kategóriáinak, valamint az erotikus szférának problematikus tárgyalását készítené elő. Ezekre a továbbhaladási lehetőségekre ebben a dolgozatban csak utalások

\footnotetext{
${ }^{126}$ Hadas Miklós - Zeke Gyula: Egy fölösleges ember élete. Beszélgetések Vázsonyi Vilmossal. Bp. Balassi,
} 2012. 388-9. o. 
történhettek. A cél a sorsfogalom kritikai megközelítéseinek számbavétele volt, melyet igyekeztem a lehető legnagyobb körültekintéssel elvégezni.

„Itt és egyébként mindenütt bocsánatot kell kérnem fejtegetésem minden félreérthető következményéért, mintha például úgy tűnne, hogy az az igazi feladat, hogy elvonatkoztassunk a nemitől, vagyis külsődleges értelemben semmisítsük meg. Ha a nemi egyszer már mint a szintézis szélső pontja tételeződött, hiábavaló minden absztrakció. A feladatunk természetesen az, hogy a nemit beleszőjük a szellem meghatározásába. (Ebben rejlik az erotikus összes erkölcsi problémája.) Ez akkor valósul meg, ha az emberben győzedelmeskedik a szerelem, amiben viszont a szellem jutott uralomra oly módon, hogy a nemi feledésbe merült, és csak mint elfeledett idézhető fel. Ha ez megtörtént, akkor az érzékiség szellemivé lényegül, és a szorongás elűzetik."127

„Hier wie alenthalben muß ich mir jegliche falsch verstandene Konsequenz verbitten, als ob zum Beispiel die wahre Aufgabe nun darin bestehen sollte, vom Sexuellen zu abstrahieren, d. h. im äußeren Sinne es zu vernichten. Wenn das Sexuelle als das Äußerste der Synthese einmal gesetzt ist, dann nützt alle Abstraktion gar nichts. Die Aufgabe ist natürlich die, es in Bestimmung des Geistes einzubringen. (Hier liegen alle sittlichen Probleme des Erotischen.) Die Realisierung dieser Aufgabe bedeutet jenen Sieg der Liebe in einem Menschen, bei dem der Geist in einer Weise gesiegt hat, daß das Sexuelle vergessen ist und nur im Vergessen erinnert wird. Wenn das geschehen ist dann ist die Sinnlichkeit in Geist verklärt, und die Angst ist vertrieben. " 128

\footnotetext{
${ }^{127}$ Søren Kierkegaard, A szorongás fogalma, 94.

${ }^{128}$ Søren Kierkegaard: Die Begriff Angst, 94.
} 
Ez a feladat természete szerint azonban olyan jellegü is, hogy minden leírt szó, ahogyan szándékuk szerint a jelen dolgozatban leírt és megidézett szavak is, legjobb esetben is pusztán problematikus prolegomenaként szolgálhatnak megkezdéséhez. 


\section{Felhasznált irodalom}

1. Agamben, Giorgio: State of Exception. Trans. by Kevin Attell. University of Chicago Press, 2005.

2. Améry, Jean: „A kínvallatás”. In uő: Túl bünön és bünhődésen. Esszék. Ford. Blaschtik Éva. Budapest: Múlt és Jövő, 2002.

3. Arendt, Hannah: „Előadások Kant politikai filozófiájáról”. Ford. Pató Attila. In uő: A sivatag és az oázisok. Budapest, Gond-Palatinus, 2002. 272-289.

4. Mihail Bahtyin: A szerző és a hős. Ford. Patkós Éva. Bp.: Gond-Cura Alapítvány, 2004

5. Benjamin, Walter: Angelus Novus. Értekezések, kísérletek, bírálatok. Ford. Bence György, Pór Péter, Rajnai László, Tandori Dezső, Kőszeg Ferenc. Szerk. Radnóti Sándor. Budapest: Magyar Helikon, 1980.

6. Benjamin, Walter: Gesammelte Schriften vol 1. \& 2. Herausgegeben von Rolf Tiedemann und Hermann Schweppenhäuser. Frankfurt am Mein: Suhrkamp, 1991.

7. Benjamin, Walter: „A szirének hallgatása”. Válogatott irások. Ford. Szabó Csaba. Bp.: Osiris, 2001.

8. Benjamin, Walter: A mükritika fogalma a német romantikában. Ford. Ábrahám Zoltán. Bp.: Gond-Cura Alapítvány - Új Palatinus-Könyvesház Kft., 2004.

9. Bernhard, Thomas: Megzavarodás. Ford. Adamik Lajos. Pozsony: Kalligram, 2006.

10. Bibó István: „Etika és büntetőjog”, in uő: Válogatott tanulmányok, I. kötet, Magvető, 1986.

11. Bibó István: „Zsidókérdés Magyarországon 1944 után”. In Bibó István: Válogatott tanulmányok. Corvina, 2004. 
12. Bibó István: „A német politikai hisztéria okai és története.” In Bibó István: Válogatott tanulmányok. Corvina, 2004. 9-76.

13. Borowski, Tadeusz: „Hölgyeim és Uraim, parancsoljanak a gázba fáradni”. Ford. Fejér Irén. In Tadeusz Borowski: Kővilág. Válogatott versek és elbeszélések. Budapest: Múlt és Jövő Kiadó, 1999.

14. Butler, Judith: "Walter Benjamin and the Critique of Violence”. In Butler: Parting Ways: Jewishness and the Critique of Zionism. Columbia University Press, 2012.

15. Dante Alighieri: Isteni színjáték. Ford. Babits Mihály. Európa, 1974.

16. Derrida, Jacques: „Force of Law. The $>>$ Mystical Foundation of Authority $<<”$. Trans. by Mary Quaintance. Cardozo Law Review. vol. 11:919, 1989-90. p. 920-1046.

17. Derrida, Jacques: „A törvény ereje: az >>autoritás misztikus alapja<<”, in Gulyás Gábor, Széplaky Gerda (szerk.): Az árnyék helye. Tanulmányok a hatalom, a morál és az eröszak kérdéseiröl. Kalligram, Pozsony, 2011, 227-261.

18. De Wilde, Marc: “Meeting Opposites: The Political Theologies of Walter Benjamin and Carl Schmitt.” Philosophy and Rhetoric, vol. 44, no. 4, 2011. pp. 363-381.

19. Dosztojevszkij, Fjodor Mihajlovics: Ördögök. Ford. Makai Imre. Bp. Európa: 1983.

20. Foucault, Michel: Felügyelet és büntetés. A börtön története. Ford. Fázsy Anikó és Csürös Klára. Budapest: Gondolat, 1990 (1975).

21. Földényi F. László: „Az irodalom gyanúba keveredett”. Kertész Imre-szótár. Bp.: Magvető, 2007.

22. Gehring, Petra: Force and "Mystical Foundation" of Law: How Jacques Derrida Addresses Legal Discourse. In German Law Journal vol. 6, 2005, 151-169: http://www.germanlawjournal.com/pdfs/Vol06No01/PDF_Vol_06_No_01_151169_SI_Gehring.pdf 
23. Hadas Miklós - Zeke Gyula: Egy fölösleges ember élete. Beszélgetések Vázsonyi Vilmossal. Bp. Balassi, 2012.

24. Hamacher, Werner: „Afformatív, sztrájk.” Ford. Szabó Csaba. In Gulyás Gábor, Széplaky Gerda szerk.: Az árnyék helye. Tanulmányok a hatalom, a morál és az eröszak kérdéseiröl. Kalligram, Pozsony, 2011. 197-226.

25. Hamacher, Werner: „Büntörténet (Benjamin vázlata: >>A kapitalizmus mint vallás $<<"$ Ford. Pál Katalin. In http://etal.hu/kotetek/gazdasagi-teologia2013/hamacher-buntortenet/ etal.hu kritikai elmélet online, 2013, Gazdasági Teológia. Szerk. Fogarasi György.

26. Henningsen, Gustav: A boszorkányok ügyvédje. A baszk boszorkányság és a spanyol inkvizició (1609-1614). Ford. Szuhay-Havas Ervin. Kossuth, 1988.

27. Hölderlin, Johann Christian Friedrich: Versek ; Hüperión. Vál. Rónay György, a verseket ford. Bernáth István et al., a levélregényt ford. Szabó Ede. Budapest : Európa, 1993.

28. Huizinga, Johann: Homo ludens. Kisérlet a kultúra játék-elemeinek meghatározására. Ford. Máthé Klára. Bp. Athenaeum, 1944.

29. Kádár Gábor és Vági Zoltán: A végső döntés. Berlin, Budapest, Birkenau 1944. Budapest: Jaffa, 2013.

30. Kafka, Franz: A per. Ford. Györffy Miklós. Palatinus, 2002.

31. Kant, Immanuel. A tiszta ész kritikája. Ford. Kis János. Budapest: Atlantisz, 2009.

32. Kant, Immanuel: „Az örök békéröl. Filozófiai tervezet (1795-96).” Ford. Mesterházi Miklós. In Kant: Történetfilozófiai írások. Ictus, 1995-97.

33. Kant, Immanuel: A gyakorlati ész kritikája. Ford. Berényi Gábor. Budapest: Cserépfalvi, 1996.

34. Kertész Imre: K. dosszié. Szerkesztette Hafner Zoltán. Magvető, Budapest, 2006. 
35. Kertész Imre: Gályanapló. Magvető, 1999 (1992).

36. Kertész Imre: Sorstalanság. Magvető, 2010 (1975).

37. Kierkegaard, Søren: A szorongás fogalma. Ford. Rácz Péter. Göncöl, 1993.

38. Kierkegaard, Søren: Der Begriff Angst. Aus dem Dänischen übersetzt von Gisela Perlet. Stuttgart: Phiilipp Reclam jun. GmbH. 2012 (1992).

39. Luxemburg, Rosa: „Tömegsztrájk, párt és szakszervezetek”, in uő: A szakszervezetek és a tömegsztrájk. Ford. Nyilas Vera, Petri György, Rózsa István. Szerk. Hamburger Mihály. Budapest: Táncsics, 1976.

40. Molnár Sára: Ugyanegy téma variációi. Irónia és megszólitás Kertész Imre prózájában. Kolozsvár: Koinónia, 2005.

41. Móricz Zsigmond: „Árvácska.” In uő: Pillangó / Árvácska. Bp. Szépirodalmi, 1976.

42. Ovidius Naso, Publius: Átváltozások. Fordította Devecseri Gábor. Magyar Helikon, 1964.

43. Pasolini, Pier Paolo: „Dante költői szándékáról.” Ford. Lukácsi Margit. In Pasolini: Eretnek empirizmus. Bp. Osiris, 2007.

44. Platón: „Állam.” Szabó Miklós fordítása. Platón összes müvei, II. kötet. Budapest, Európa, 1984.

45. Platón: „Parmenidész”. Ford.: Kövendi Dénes. Platón összes müvei II. Budapest, 1984.

46. Rabinow, Paul and Rose, Nikolas eds.: The Essential Foucault. Selections from The Essential Works of Foucault 1954-1984. New York: The New Press, 2003.

47. Rosenzweig, Franz: Der Stern der Erlösung. Freiburg im Breisgau: Universitätsbibliothek, 2002.

48. Rousseau, Jean-Jacques: Társadalmi szerződés. Ford.: Radványi Zsigmond. Budapest: Phönix-Oravetz, 1947. 
49. Schmitt, Carl: „A parlamentarizmus és a modern tömegdemokrácia ellentéte”. In uő: $A$ politikai fogalma. Ford. Cs. Kiss Lajos. Budapest: Osiris - Pallas Stúdió - Attraktor, 2002.

50. Sorel, Georges: Gondolatok az erőszakról. Ford. Burján Mónika, Lukács Katalin és Szénási Éva. Századvég, 1994.

51. Spiró György: „Non habent sua fata. A Sorstalanság - újraolvasva”. Élet és Irodalom, 1983/30.

52. Tarkovszkij, Andrej: A megörökített idö. Ford. Vári Erzsébet. Osiris, 2002.

53. Vári György: Kertész Imre. Buchenwald fölött az ég. Bp. Kijárat Kiadó, 2003. 9-85.

54. Weber, Samuel: "Taking Exception to Decision: Walter Benjamin and Carl Schmitt." Diacritics, Vol. 22, No. 3/4, Commemorating Walter Benjamin (Autumn - Winter, 1992), pp. 5-18. 